Universidade de São Paulo

Faculdade de Filosofia, Letras e Ciências Humanas

Departamento de Geografia

Programa de Pós-Graduação em Geografia Humana

Aline Lima Santos

\title{
Mudança de vento: a migração do Brasil para Portugal no fim do século XX e início do século XXI
}


Aline Lima Santos

\section{Mudança de vento: a migração do Brasil para Portugal no fim do século XX e início do século XXI}

Dissertação de Mestrado apresentada ao Programa de Pós-Graduação em Geografia Humana da Faculdade de Filosofia, Letras e Ciências Humanas da Universidade de São Paulo para obtenção do título de Mestre em Geografia. Área de Concentração: Geografia Humana.

\section{VERSÃO CORRIGIDA}

Orientadora: Profa. Dra. Rosa Ester Rossini

De acordo: 
Este trabalho é dedicado à Gilberto Moreira dos Santos (in memorian), meu pai e maior incentivador 


\section{Agradecimentos}

Este trabalho teve apoio da Fundação de Amparo à Pesquisa (FAPESP), por meio de bolsa de mestrado, e da Cátedra Jaime Cortesão que, patrocinada pelo Instituto Camões, ofereceu auxílio para pesquisa de campo em Portugal. Sem a concessão destes subsídios não seria possível o desenvolvimento do projeto, por isso, presto agradecimento a essas instituições.

Minha mais sincera gratidão e reconhecimento à Profa. Dra. Rosa Ester Rossini, cuja orientação acadêmica imprescindível sempre veio acompanhada de lições de vida. Incontáveis foram os momentos de encorajamento e ânimo, mas também de cobrança de resultados. Em todos eles foi notável seu apoio, paciência, carinho e sabedoria. Nesses anos de convivência seus ensinamentos foram preciosos para meu crescimento intelectual, científico e como pessoa.

Em Portugal tive a honra de ser recebida pela Profa. Dra. Maria Beatriz Rocha-Trindade. Agradeço profundamente as inúmeras contribuições que me concedeu em todas as vezes que tivemos a oportunidade de nos encontrar. Nossas mais simples conversas vinham sempre repletas de valiosas indicações e esclarecimentos. Poder contar com sua colaboração foi, realmente, um grande privilégio.

Meus agradecimentos ao prestativo Prof. José Marques, que, no Centro de Estudos Sociais (CES) da Universidade de Coimbra, estava gentilmente disposto a compartilhar suas experiências de pesquisa sobre a comunidade brasileira. Sua colaboração veio preencher a lacuna deixada pela Profa. Dra. Maria Ioannis Baganha, que, infelizmente, faleceu pouco tempo antes de minha chegada a Portugal.

Aos funcionários da Universidade Aberta, do Centro de Estudos Sociais da Universidade de Coimbra e do Departamento de Geografia da Universidade de São Paulo minha consideração e gratidão pela paciência e solicitude.

Meus agradecimentos dirigem-se também ao casal Joice e Weber, com os quais estive durante o mês que permaneci em Lisboa. À Beatriz Coelho, que em Coimbra, prontamente se dispôs a dividir seu quarto na casa da D. Rosa, a quem igualmente sou grata. À Sara Garrido por me apresentar Coimbra de 
modo tão atencioso. À Hália e Antonio, que me receberam na cidade do Porto calorosamente o que colaborou para que eu tivesse a melhor imagem possível do povo português. À Paula Barahona, por sua simpática e agradável companhia capaz de fazer esquecer as saudades de casa.

Agradeço aos homens e mulheres, brasileiros e portugueses que vivem em Portugal e dispensaram parte de seu tempo respondendo entrevistas e prestando esclarecimentos. Destaco de maneira especial: a Chefa do Consulado-Geral do Brasil no Porto, Dra. Cláudia D’Angelo; o Adido Policial Adjunto em Lisboa, Dr. Eduardo Celestino; o Diretor do Serviço Jesuíta aos Refugiados, André Costa Jorge, bem como à psicóloga Alexandra Santiago; o Pe. Mário Silva, do Centro Padre Alves Correia; o Diretor da Obra Católica Portuguesa de Migrações, Fr. Francisco Diniz; o Vice-presidente da Casa do Brasil de Lisboa, Luiz Leiria e a Ísis Silva, responsável pelo acervo desta instituição.

Cito ainda Lyria Reis, Willame Silva e Zelita Teles pela atenção e cuidados dispensados comigo durante minha estada em Lisboa. Sem seu apoio, certamente minha pesquisa de campo teria enfrentado dificuldades.

Muito obrigada aos professores André Martin, Armen Mamigonian, Fábio Contel, Heinz Dieter, Maria Laura, Mónica Arroyo, Wanderley da Costa, pelo incentivo, sugestões e conhecimento compartilhado.

Obrigada aos colegas do Laboratório de Geografia Política e Planejamento Territorial e Ambiental (LABOPLAN) pela convivência cotidiana na qual dividimos experiências e angustias. Em especial minha gratidão à Ana Pereira, que vive para acalmar os ânimos dos que estão com os prazos acabando! Pelo incentivo que deu em todas as etapas de desenvolvimento do projeto e pela gentileza de dispor-se a colaborar na transcrição das entrevistas realizadas. Sem sua ajuda, certamente eu não teria dado conta do volume de tarefas envolvidas nessa pesquisa.

Sou muito grata à Elisa Freitas por sua contagiante empolgação pelo conhecimento e pelas inúmeras sugestões e proveitosas discussões, além da ajuda com textos em inglês; à Elisangela Couto pela amizade, senso de humor e pragmatismo; a Antonio Marcos Roseira pelas criteriosas indicações, esclarecimentos e debates. Devo certamente a esses amigos a conquista da disciplina necessária para o estudo. 
Agradeço a Carlos Póvoa, pelo estímulo e exagero em salientar que eu cresci; a Daniel Huertas, pelo incentivo e provocações; a Mateus Sampaio, pela tranqüilidade, seriedade e amizade; a José Fonseca pelo companheirismo, pela "caneta vermelha", pelas caronas e risadas; a Jonatas dos Santos pela ajuda com o inglês, pelos momentos de descontração e disponibilidade; a Elvis de Oliveira pela descontração e amizade; a Márcia Cristina Yamamoto, que mesmo à distância esteve atenta e colaborou de modo fundamental nesta pesquisa ao informar sobre a seleção da Cátedra Jaime Cortesão.

A Josoaldo e Márita por "abrir portas" em Portugal; a Clenes pelo apoio e orientações sobre burocracias referentes à pesquisa de campo; a Jeferson com quem comparto inquietações acadêmicas, extra-acadêmicas e planos de viagens; a Tabata pelos momentos de diversão e pela colaboração com a cartografia; a Germano de Castro pelo auxílio na "última hora" com o material cartográfico.

Agradeço aos queridos amigos Mariangela Brogini e Silas Junqueira pelo companheirismo, atenção e disponibilidade em ajudar. Muito obrigada a Lourival Alves que sempre encontra um jeito de explicitar que está torcendo por mim.

Foi fundamental o apoio de todos esses amigos mencionados e de outros, que participaram mais indiretamente do processo. A eles também minha sincera gratidão: Alessandra Costa, Amanda Reiko, Camilla Conde, Camila Thiemi, Dóris, Kinuyo, Luiz Fernando, Marcelo Miyahira, Marcelo Willians, Marcos Nogueira, Renata Mendes, Sarah Aravena.

Minha mãe, Ana Lúcia, e de minhas irmãs, Érica e Sara, no cotidiano, pacientemente estiveram dispostas a compreender minha escolha. Expresso aqui meus agradecimentos e reconhecimento de que sem vocês não teria sido possível.

Por fim, agradeço aos que se interessaram por esse trabalho e o julgaram digno de ser lido. 


\section{Resumo}

SANTOS, Aline Lima. Mudança de vento: a migração do Brasil para Portugal no fim do século XX e início do século XXI. 2010. 210f. Dissertação de Mestrado. Faculdade de Filosofia, Letras e Ciências Humanas. Universidade de São Paulo, São Paulo, 2010.

No fim do século $X X$, a emigração tornou-se um fenômeno importante nas dinâmicas da população do Brasil. O fluxo de brasileiros para Portugal surge nesse momento como algo novo e dá conteúdos originais a uma antiga relação. A inversão do fluxo tradicional constitui um novo padrão, com sentido contrário ao que se estabeleceu desde o período colonial até meados do século. Essa inversão insere-se em um contexto mais amplo de reordenamento das migrações internacionais após 1945, o qual, por sua vez, relaciona-se às profundas transformações sociais, políticas, econômicas e espaciais que o mundo passava a conhecer. A partir de então a Europa concentra grande número de imigrantes - provenientes do próprio continente e de outras partes - o que reflete seu papel na divisão internacional do trabalho e sua influência geopolítica. Esse contingente populacional estrangeiro faz desacelerar a queda do crescimento populacional nos países europeus e satisfaz as necessidades de seus mercados de trabalho, inserindo-se em setores nos quais há pouca oferta de mão de obra ou naqueles trabalhos que os autóctones recusam-se a realizar. Os brasileiros em Portugal seguem essa tendência. Porém, os imigrantes colocam aos principais países receptores o problema do número e do acesso à cidadania, esta última ainda fortemente vinculada ao Estado territorial, que no atual período da globalização redefine-se em virtude do aparecimento de novos atores no sistema internacional. Assim, são constrangidas a autonomia e soberania dos países quanto às políticas de migração a serem adotadas de modo a atender seus interesses. As migrações internacionais contemporâneas estabelecem, portanto, novos conteúdos nas relações entre território, Estado e população. Nesse contexto, Portugal subordina suas políticas de imigração às da Europa, mas, ao mesmo tempo, privilegia imigrantes do Brasil e das ex-colônias africanas, com os quais também procura fortalecer vínculos econômicos e políticos. O Brasil, por sua vez, solicitado por seus emigrantes, passa a articular políticas que visam atendê-los em suas necessidades. Estado de origem e Estado receptor, portanto, compartilham uma população híbrida, lusobrasileira, que os obriga a se relacionar e torna-se componente de suas estratégias de inserção no mundo.

Palavras-chave: migrações internacionais contemporâneas, população, território, Estado. 


\section{Abstract}

SANTOS, Aline Lima. Change of wind: the migration from Brazil to Portugal in the late twentieth and early twenty-first century. 2010. 210f. Dissertação de Mestrado. Faculdade de Filosofia, Letras e Ciências Humanas. Universidade de São Paulo, São Paulo, 2010.

At the end of the twentieth century, the emigration has become a significant phenomenon in the brazilian population dynamics. The flow of brazilian population to Portugal emerges, at this moment, as something new, supplying with primary information an ancient relation. The inversion of the traditional flow constitutes itself a new pattern, but in opposite direction from the original movement established since the colonial period until de middle of last century. This inversion falls in a wider context of relocation of international migration after 1945, which relates itself within deeply social, political, economic and spatial changes throughout the world. Thenceforward, Europe concentrated a massive number of migrants - coming from within its own borders which reflects its role in the international division of labor and its geopolitical influence. This foreign migrant quota has decelerated the decline of the populational growth in European countries, and meets the needs of the labor market, infiltrating themselves in places with decreased supply of labor, or in sections of labor that local people refuses to accept. The Brazilians living in Portugal tend to follow that pattern. However, the immigrants raise to the mainly receptors countries the matter of number and access to citizenship, this latter still strongly attached to the territorial state, which immersed in the globalization period, redefines itself due to the emerging of new actors in the international system. Therefore, the autonomy and sovereignty of these countries are constrained, especially over the migration politics to be held in a sense of serving their own interests. The international contemporary migration established, accordingly, a new content in the relations between territory, State and population. Thus, Portugal immigration politics undergoes the very ones of Europe, but, at the same time, privileges Brazilian immigrants and the African ex-colonies, with which still seeks invigorate political and economic links. Brazil, requested by its emigrants, starts to sew up politics capable of meets their needs. Home state and receiver state, therefore, share a hybrid population, luso-brazilian, that obligates one and another to relate and become a very component of its own strategies in entering the world.

Key-words: contemporary international migration, population, territory, State. 


\section{Lista de esquemas}

Esquema 1: Migrações internacionais no mundo atual.

Esquema 2: Preferências do mercado de trabalho português quanto à gênero e

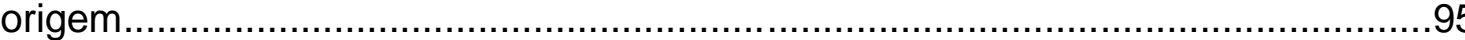

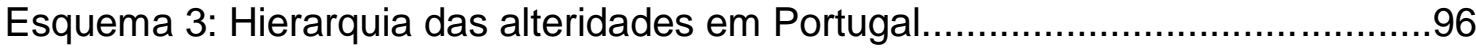

Esquema 4: Mercado de Trabalho na globalização...........................................132 


\section{Lista de figuras}

Figura 1: A Grande Migração Transatlântica.......................................................11

Figura 2: Emigração portuguesa por distrito de naturalidade................................15

Figura 3: Principais Movimentos Migratórios, situação em 2005............................24

Figura 4: Dispersão de imigrantes, por distritos, no território português, situação em 2008.

Figura 5: Os três grandes pólos do comércio global. 40

Figura 6: Estrangeiros na população dos distritos, situação em 1991, 2001 e 2003.

Figura 7: Brasileiros na população dos distritos, situação em 2008 .68

Figura 8: Crescimento do número de brasileiros por distritos, situação no período de 1999-2004. 69

Figura 9: Mulheres detectadas como vítimas de tráfico, segundo país de origem, para fins de exploração sexual na Europa Ocidental, situação no período de 2005 a 2007.

Figura 10: Fluxos de remessas internacionais, situação no período 2006-2007..162 


\section{Lista de Fotos}

Foto 1: Monumento aos emigrantes portugueses............................................13

Foto 2: Casa de emigrante............................................................................

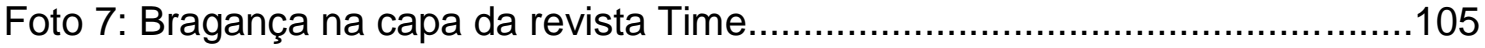

Foto 4: Loja de produtos brasileiros..............................................................117

Foto 5: Centro de estética brasileiro...............................................................117

Foto 6: Igrejas evangélicas brasileiras..........................................................118 


\section{Lista de Gráficos}

Gráfico 1: Evolução da população estrangeira residente em Portugal no período de $1960-2008$

Gráfico 2: Nacionalidades mais representativas no total da população estrangeira

residente em Portugal, situação em 2008.

Gráfico 3: Imigrantes em Portugal por grupo etário, situação em 2008 39

Gráfico 4: Pirâmide etária de Portugal, situação em 2003 e 2008 .42

Gráfico 5: Distribuição de brasileiros que vivem no exterior, situação em 2009.

Gráfico 6: Percentual de imigrantes brasileiros em relação aos dez principais países receptores, situação em 2009.

Gráfico 7: Evolução do número de brasileiros no total de estrangeiros com autorização de residência (A. R.) em Portugal no período de 1960 a 2008

Gráfico 8: Evolução do número de brasileiros com autorização de residência (A.

R.) em Portugal no período de 1980 a 2008. .52

Gráfico 9: Evolução do percentual de brasileiros com autorização de residência ( $A$. R.) em Portugal no período de 1960 a 2008. .53

Gráfico 10: Brasileiros não admitidos em Portugal por motivo de recusas - situação em 2008.

Gráfico 11: Evolução de estrangeiros inscritos na Ordem dos Enfermeiros, situação de 2003 a 2009

Gráfico 12: Evolução da mobilidade socioprofissional de trabalhadores imigrantes em Portugal. 
Gráfico 13: Profissões desempenhadas pela população brasileira ativa, situação em 1991

Gráfico 14: Profissões desempenhadas pela população brasileira ativa, situação em 2001

Gráfico 15: População estrangeira feminina em Portugal, evolução no período de 1980 a 2008

Gráfico 16: Principais áreas de origem das mulheres identificadas em ações do SEF em situação de alterne e/ou prostituição no período de 2003 a 2007.

Gráfico 17: Mulheres identificadas em ações do SEF em situação de alterne e/ou prostituição no período de 2003 a 2007.

Gráfico 18: Portugal e as políticas para integração, situação em 2006

Gráfico 19: Brasil e Portugal: fluxos de entrada de remessas no período 1975 2009.

Gráfico 20: Brasil e Portugal: fluxos de saída de remessas no período 1975 2008

Gráfico 21: Brasil e Portugal: saldo dos fluxos de remessas no período 1975 2008. 


\section{Lista de Tabelas}

Tabela 1: Participação dos brasileiros no total de habitantes dos dez principais países receptores - situação em 2009 .

Tabela 2: Diferenciação geral das duas vagas de migração brasileira para Portugal...

Tabela 3: Brasil e Portugal: percentual dos fluxos de entrada por origem das remessas, situação em 2008. 


\section{Lista de abreviaturas e siglas}

ACIDI - Alto Comissariado para Imigração e Diálogo Intercultural

ACIME - Alto Comissariado para as Imigrações e Minorias Étnicas

BB - Banco do Brasil

BID - Banco Interamericano de Desenvolvimento

CBL - Casa do Brasil de Lisboa

CEF - Caixa Econômica Federal

CEPAC - Centro Padre Alves Correia

CEPAL - Comissão Econômica para América Latina

CLAI - Centro Local de Apoio ao Imigrante

CNAI - Centro Nacional de Apoio ao Imigrante

COCAI - Conselho Consultivo para os Assuntos da Imigração

CRBE - Conselho de Representantes de Brasileiros no Exterior

DCIPAI - Direção Central de Investigação, Pesquisa e Análise da Informação

FUMIN - Fundo Multilateral de Investimentos

IBGE - Instituto Brasileiro de Economia e Estatística

IED - Investimento estrangeiro direto

INE - Instituto Nacional de Pesquisa de Portugal

IPEA - Instituto de Pesquisa Econômica Aplicada

JRS - Serviço Jesuíta aos Refugiados

MIPEX - Índice de Política de Integração de Migrantes

MRE - Ministério das Relações Exteriores

OCPM - Obra Católica Portuguesa para as Migrações

OIT - Organização Internacional do Trabalho

ONU - Organização das Nações Unidas

PNAD - Pesquisa Nacional por Amostra de Domicílio

PNUD - Programa das Nações Unidas para o Desenvolvimento

PT - Partido dos Trabalhadores do Brasil

SCAL - Secretariado Coordenador das Associações para a Legalização

SEBRAE - Serviço Brasileiro de Apoio às Micro e Pequenas Empresas

SEF - Serviço de Estrangeiros e Fronteiras

UE - União Européia

UHSA - Unidade Habitacional Santo Antonio

UNFPA - Fundo de População das Nações Unidas

UNODC - Escritório das Nações Unidas sobre Drogas e Crimes 
Sumário

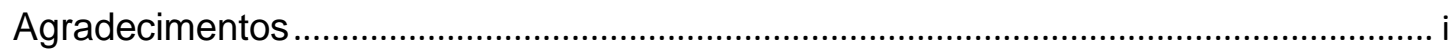

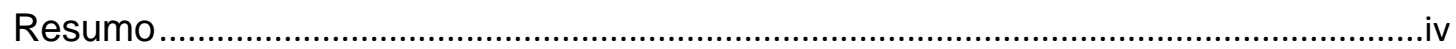

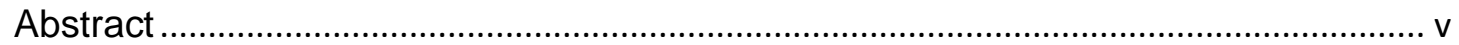

Lista de esquemas ...................................................................................................

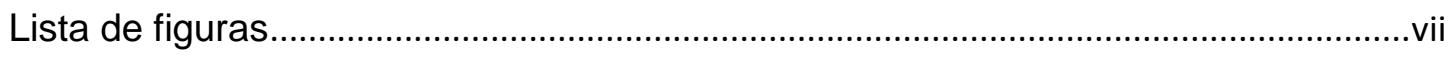

Lista de Fotos.......................................................................................................... viii

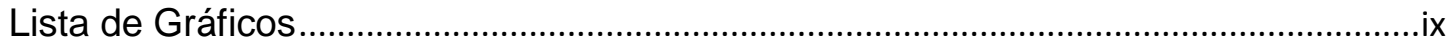

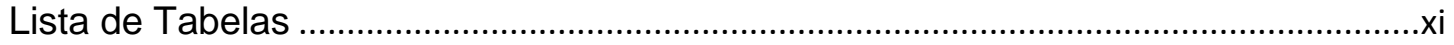

Lista de abreviaturas e siglas ............................................................................

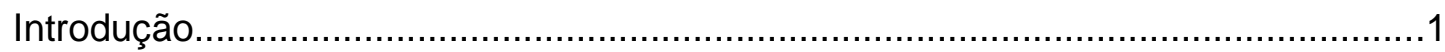

Capítulo 1 - Antes, de lá pra cá. Agora, daqui pra lá: Brasil e Portugal nos

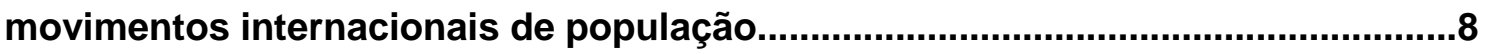

1.1 Dois períodos de chegada de portugueses no Brasil ........................................ 9

1.1.1 Até meados do século XX: de lá pra cá ................................................. 9

1.1.2 Meados do século XX a 1980: uma transição ........................................... 18

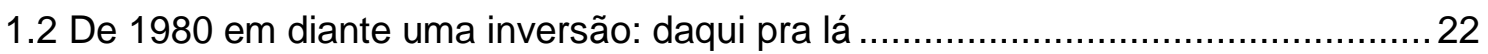

1.2.1 Para onde vão os brasileiros? ............................................................ 45

1.2.2 Portugal - promissor e incerto: uma escolha de migrantes brasileiros ........50

Capítulo 2 - Brasileiros em território português: oportunidades e desafios 67

2.1 Inserção nos extremos de um mercado de trabalho dual: trabalhadores brasileiros

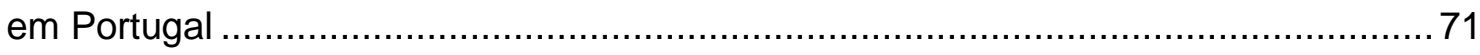

2.1.1 A feminização da imigração brasileira em Portugal................................. 89

2.1.2 Imagens do outro e a incorporação de brasileiros no mercado de trabalho

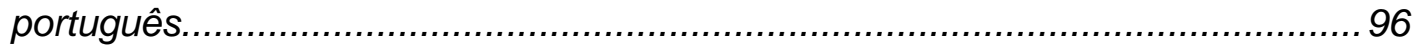

2.1.3 Brasileiras no mercado do sexo em Portugal ...................................... 108

2.2 Imigrantes brasileiros e desafios enfrentados ............................................... 116 
Capítulo 3 - Implicações do fenômeno migratório contemporâneo para as relações entre Brasil e Portugal

3.1 Pós-Segunda Guerra: novo mapa das migrações no mundo.......................... 125

3.2 Migrações em tempos de globalização 130

3.3 Políticas Migratórias no país de origem e destino e práticas transnacionais dos migrantes 139

3.3.1 Associativismo e políticas de imigração em Portugal. 140

3.3.1 Associativismo e políticas brasileiras relativas aos emigrantesl. 153

3.3.3 Remessas de migrantes no Brasil e em Portugal 161

Considerações Finais. 171

Bibliografia 175 


\section{Introdução}

O fluxo atual de brasileiros para Portugal insere-se no contexto mais amplo das migrações internacionais no mundo. Estima-se que hoje aproximadamente 214 milhões de pessoas vivem fora de seu país de nascimento, o que significa aproximadamente $3,1 \%$ da população mundial (United Nations, 2009). Tais números evidenciam a amplitude atual do fenômeno e é uma expressão do dinamismo da presença humana no planeta.

Discutir as migrações contemporâneas implica observar um fenômeno revelador de um conjunto de circunstâncias e fatos que possuem nexos entre si, e constituem o sistema internacional no período da globalização. A reflexão aqui presente visa dar relevo especial às causas e implicações das migrações internacionais nas relações entre território, Estado e população.

Historicamente, nas ciências humanas e sociais, essas relações foram interpretadas tendo como pressuposto que o Estado existia em decorrência de uma sociedade que, instalada em um território, exerceria sua soberania. $O$ território seria entendido como base material do Estado e, por conseguinte, de uma sociedade.

Inspirados nisso, os conhecimentos relativos à população, ou seja, à sociedade vista como uma coleção de seres humanos, seriam importantes ao Estado, pois permitiriam dimensionar uma das fontes de seu poder. Nesse sentido, a população e tudo o que demais está contido no território seriam recursos ou energias que servem de motivador a práticas e estratégias do Estado.

Tais fundamentos salientam a existência de relações indissociáveis entre território - Estado - população e dão até hoje suportes para se pensar também as migrações internacionais, pois essas ocorrem ainda em um cenário internacional dividido em Estados Nacionais. Esse cenário, contudo, tem sofrido profundas transformações no contexto atual de globalização, trazendo à tona os limites da noção de Estado Territorial ou, dito de outro modo, de contêiner social.

O fim da Segunda Guerra Mundial marca o início de um novo período da história da humanidade, o período técnico-científico, que vai atingir mais 
efetivamente os países pobres apenas a partir da década de 1970. Sinônimo de globalização, este novo período é caracterizado pelo entrelaçamento cada vez maior entre ciência e técnica, que passam a obedecer às ordens impostas pelo mercado (Santos, 2002).

No presente a instantaneidade, o imperativo da velocidade da informação, o aumento dos fluxos e difusão de um meio extremamente racional e artificial, o meio técnico-científico-informacional, constituem o mundo do efêmero. Este desemboca numa profunda crise de valores, culminando em um exacerbado individualismo e em uma sociedade que pode ser definida como insatisfeita (Heller, 1996).

No plano da técnica, nunca houve difusão tão rápida de um único sistema, que possibilita as mesmas formas de fazer em qualquer parte do globo. Os meios de transporte e de comunicação ganham velocidade e simultaneidade nunca antes verificada, o mundo, por isso, parece encolher-se. No plano econômico temos a consolidação de blocos comerciais entre países, uma fase em que se verificou 0 aprofundamento do neoliberalismo e o crescimento dos setores de serviço e da economia informal.

No plano político, as grandes corporações tornam-se cada vez mais poderosos atores políticos, passando a interferir diretamente nos territórios nacionais de acordo com seus interesses. Em contrapartida, o Estado nacional, em especial nos países subdesenvolvidos, torna-se permissivo, pois abre mão de certo grau de sua soberania sobre o seu território. Seu papel fundamental passa a ser o de regulação das atividades das grandes empresas, praticamente deixando de atentar para as necessidades de sua população.

Há, ainda, aumento da atuação e da visibilidade de organismos internacionais como o FMI, o Banco Mundial, entre outros. Aparecem também novos atores, como as ongs e os movimentos sociais, cuja atuação alcança discussões no âmbito internacional de temas relacionados aos direitos humanos, segurança, meio ambiente, entre outros.

Esses processos compõem hoje o espaço geográfico, o qual é tomado aqui como uma instância da sociedade, tais como a política, a economia, a cultura. Essa posição alinha-se à proposta de Santos (1985), segundo o qual "como instância, ele (o espaço geográfico) contém e é contido pelas demais instâncias, assim como cada uma delas contém e é por ele contida. (...) Isso 
quer dizer que a essência do espaço é social" (p. 2). O espaço geográfico, assim visto, não é meramente palco ou receptáculo das ações humanas, não é apenas materialidade, mas sim um sistema ativo. Trata-se, pois, da materialidade em seu movimento, em seu dinamismo, conferido pela sociedade.

Evidentemente, a separação até aqui exposta, no plano social, técnico, econômico e político, é apenas recurso de escrita. Na realidade todos os elementos estão intrínseca e contraditoriamente relacionados. O que nos permite afirmar que o espaço geográfico nunca teve tamanha complexidade e espessura. As escalas se superpõem. As soberanias e autonomias dos Estados nacionais são relativizadas.

Em decorrência disso, redefine-se o território. Não é suficiente associá-lo à face material do Estado nacional. Há, além disso, elementos multiescalares e multidimensionais, horizontalidades e verticalidades e diferentes usos de diversos atores. Verifica-se, portanto maior complexidade dos territórios nacionais e da figura estatal. Tais transformações podem ser capturadas por meio dos movimentos populacionais contemporâneos, sendo esse o objetivo geral a que se propõe esse trabalho.

Esse objetivo geral desdobra-se em objetivos específicos baseados na análise e interpretação do fluxo de brasileiros para Portugal que a partir da década de 1980 conhece crescimento significativo. Busca-se compreender as particularidades desse movimento e, ao mesmo tempo, apreender em que medida esse fluxo revela características gerais dos movimentos internacionais contemporâneos de população.

As assimetrias presentes no período atual, às quais até aqui se tenta oferecer elementos elucidativos, ratificam a idéia clássica de que as migrações são seletivas. Como afirma Trewartha (1974), "as migrações são específicas e particulares a certos continentes, países, regiões, localidades e cidades" (p.166). Além disso, "certos elementos da população tendem a ser mais migratórios que outros" (p.167). Os fluxos de brasileiros manifestam essa lógica de seletividade; busca-se desvendá-las no decorrer da pesquisa de modo a colaborar com os objetivos que se espera atingir. 
No caso específico aqui tratrado a migração é uma ação deliberada e não resultado de coerção, pelo menos não diretamente. Concorda-se com Beaujeu-Garnier (1967) quando essa autora assevera:

"O homem é uma criatura móvel, capaz de investigar, suscetível a sugestão e dotado de imaginação e iniciativa. Isso explica a razão pela qual, tendo concebido a idéia de que suas necessidades podem ser satisfeitas algures, decide não só ir a esse lugar, como também, sobre os meios porque seu projeto pode ser realizado" (p. 199).

Por conseguinte, a análise da migração exige o esforço de não suprimir a práxis individual. Porém, ao mesmo tempo, é necessário buscar dar conta da estrutura e do movimento da sociedade. Assim, temos como premissa o que nos afirma Santos [a] (2005):

\begin{abstract}
"O que, na verdade, ocorre é que a prática, a práxis, é, antes do mais, uma realidade estrutural, estruturada e estruturante ao mesmo tempo; assim ela depende estreitamente da totalidade social e não o contrário. Os comportamentos dos indivíduos, isto é as práxis individuais, são subordinados, estruturados pela práxis social. A liberdade que é frequentemente reconhecida aos agentes não é outra coisa senão sua participação nas práxis coletivas, por intermédio de uma escolha limitada de opções já incluídas na própria estrutura” (p.129).
\end{abstract}

A preocupação aqui não está centrada propriamente nas pessoas que migram. Deseja-se, isto sim, compreender o contexto que as envolvem, buscando na estrutura social as articulações que permitem esse ato e em que medida esse ato, tomado coletivamente, é semente de transformação social. É um desafio ao pesquisador encontrar um ponto de equilíbrio que the permita analisar as questões relacionadas com as migrações valorizando tanto o poder do indivíduo quanto as condições nas quais ele está inserido. Evidentemente, as experiências individuais são importantes, contudo o são porque revelam aspectos da estrutura no qual se insere.

Metodologicamente isso repercutiu na pesquisa de campo realizada no período de 15/09/2009 a 19/11/2009. Privilegiou-se a obtenção de dados secundários e a realização de entrevistas semi dirigidas com imigrantes brasileiros em Portugal e outros informantes privilegiados.

O roteiro seguido incluiu as cidades de Lisboa, Coimbra e Porto. Quando houve necessidade, extrapolou-se o âmbito das cidades para as áreas de 
influência das mesmas, como Cascais e Sintra, na região de Lisboa, ou Gaia, na região do Porto. Abaixo lista-se as instituições visitadas em ordem mais ou menos cronológica. Nelas, de modo geral, foram realizadas entrevistas com os diretores e visitas a bibliotecas e acervos. Algumas dessas instituições foram visitadas mais e uma vez, é o caso, por exemplo, daquelas que dispunham de bibliotecas e acervos.

\section{Lisboa}

Período de 16/09/2009 a 19/10/2009

Instituições visitadas:

1. OCPM (Obra Católica Portuguesa para Migrações)

2. Universidade Aberta

3. CEPAC (Centro Padre Alves Correia)

4. Casa do Brasil em Lisboa

5. Serviço Jesuíta aos Refugiados

6. Universidade de Lisboa (ICS - Instituto de Ciências Sociais, ISCTE - Instituto Superior de Ciências do Trabalho e da Empresa, Departamento de Geografia)

7. Embaixada do Brasil

8. Consulado do Brasil

9. Igreja Assembléia de Deus

10. ACIDI (Alto Comissariado para a Imigração e Diálogo Intercultural); CNAI (Centro Nacional de Apoio ao Migrante)

11. Shopping Colombo

12. Shopping Vasco da Gama

\section{Coimbra}

Período de 20/10/2009 a 01/11/2009

Instituições visitadas:

1. Universidade de Coimbra (Faculdade de Economia, Faculdade de Letras)

3. CES - Centro de Estudos Sociais (UC)

4. Igreja Batista

5. Shopping Gira Solum

6. Shopping Dolce Vita

\section{Porto}

Período de 02/09/2009 a 19/11/2009

Instituições visitadas:

1. Universidade do Porto (Faculdade de Economia, Faculdade de Psicologia)

2. Shopping Dolce Vita

3. Embaixada do Brasil

4. Reunião dos Atletas de Cristo

5. CNAI (Centro Nacional de Apoio ao Imigrante)

6. UHSA (Unidade Habitacional de Sto. António) 
A Casa do Brasil de Lisboa, a Obra Católica Portuguesa de Migrações (OCPM), o Alto Comissariado para a Imigração e Diálogo Intercultural (ACIDI), especialmente o Centro Nacional de Apoio ao Imigrante (em Lisboa e no Porto), o Centro Padre Alves Correia (CEPAC), o Serviço Jesuíta aos Refugiados, a Unidade Habitacional de Sto. António (UHSA), foram visitadas porque lidam diretamente com as demandas dos migrantes, brasileiros e outros, em território português. Cada uma possui sua especificidade, algumas apoiando os migrantes mais no sentido de oferecer informações e dar apoio legal, outras oferecendo serviços de assistência social ou apoio psicológico.

Os shoppings foram incluídos no trabalho de campo porque se constituem em verdadeiros nichos de trabalho para os migrantes brasileiros, especialmente as Praças de Alimentação. Deste modo, permitiram observar quais as condições de trabalho dessas pessoas e contatar imigrantes dispostos a conceder entrevista.

As igrejas evangélicas foram incluídas pelo mesmo motivo dos Shoppings. Isto é, nelas nota-se a concentração de brasileiros, além disso, são um meio de sociabilização dos mesmos e possibilitaram também a realização de entrevistas.

Não foram incluídos nas listas os restaurantes, lanchonetes e lojas nas quais ocorreram conversas informais, porém reveladoras, com os trabalhadores brasileiros, em virtude da exaustão a que isso levaria. Contudo, convém mencioná-los no sentido de que também se constituíram em importantes fontes para a pesquisa.

Sobre as atividades realizadas em pesquisa de campo, resta dizer que voltamos de Portugal com pouco mais de 30 entrevistas realizadas em profundidade. Os dados primários foram trabalhados, sobretudo, de modo qualitativo, como instrumento para compreensão da estrutura na qual se insere o fluxo de brasileiros para Portugal.

É importante considerar a estrutura simultaneamente ao seu movimento. Deve-se atentar, portanto, à formação paralela, dialética e concomitante da sociedade e do território. Nessa formação dinâmica é que são produzidos os fluxos migratórios.

Esses também expressam a inserção dos países na divisão internacional do trabalho e o status geopolítico que os caracterizam no sistema 
internacional. Em outras palavras, as especificidades econômicas e políticas dão identidade aos países como atores do sistema internacional, revelando seus atributos, suas esferas de influencia, seus interesses, e, até mesmo, sua capacidade de fazê-los valer. Tais características impactam profundamente os deslocamentos populacionais, pois condicionam seus direcionamentos e sentidos.

As discussões supracitadas são desenvolvidas em três capítulos. No primeiro pretendeu-se analisar as transformações do padrão migratório brasileiro e português no atual contexto de globalização a partir da maneira como esses países estão inseridos no sistema internacional. Desse modo, buscou-se elaborar uma visão conjuntural do fluxo de pessoas do Brasil para Portugal, seus principais fatores condicionantes e suas especificidades diante dos demais fluxos que partem do Brasil.

No segundo capítulo os esforços voltam-se à compreensão da inserção dos brasileiros no território português. Essa inserção na sociedade receptora se dá sob a égide de imagens recíprocas construídas historicamente capazes de estabelecer o status desses imigrantes e definir a função que devem desempenhar. Tal fato é analisado, principalmente por meio do mercado de trabalho. Atentou-se ainda para as facilidades e dificuldades cotidianas enfrentadas por essa comunidade estrangeira.

No terceiro capítulo foram retomados os principais aspectos dos anteriores visando enfatizar as implicações dos fluxos migratórios tanto para o Brasil como para Portugal. Foram destacadas, especialmente, as políticas adotadas por ambos os países para lidar com esse contingente de brasileiros que vivem em Portugal, mas recusam-se a abandonar o Brasil.

Espera-se, com isso, ter contribuído para o debate e aprofundamento dos conhecimentos sobre a população no âmbito da geografia e demais ciências que se interessam pela temática das migrações, colaborando para a compreensão desse importante fenômeno que se intensificou no período atual. 


\section{Capítulo 1 - Antes, de lá pra cá. Agora, daqui pra lá: Brasil e Portugal nos movimentos internacionais de população}

A participação de Brasil e Portugal nos movimentos migratórios internacionais é o foco desse capítulo. Adotando-se uma perspectiva diacrônica, visa-se contextualizar o período atual e compreender seus novos significados diante do processo histórico. Pretende-se alcançar uma periodização síntese que contemple os diferentes momentos dos fluxos populacionais, os quais foram constantes nas dinâmicas da circulação entre Portugal e Brasil.

A periodização permite caracterizar o funcionamento do espaço geográfico em determinado momento e, desse modo, identificar a evolução destes movimentos de pessoas nos territórios brasileiro e português. É, dessa maneira, uma ferramenta importante para apreender o modo distinto com o qual ambos participam no cenário internacional e as peculiaridades das relações que estabelecem entre si.

É possível determinar três períodos de trânsito de pessoas entre Brasil e Portugal. O primeiro vai de 1822 até meados do século $\mathrm{XX}$, o segundo vai daí até 1980, momento em que se inicia o terceiro, ainda inacabado. Pormenorizar esses diferentes momentos traz consigo a tarefa de periodizar o modo como ocorreu o fenômeno migratório nos dois países, considerando também o contexto mundial geral.

O modo como se inserem esses países no cenário internacional é elementar para compreender os fluxos que neles chegam e deles partem. Interessa aos geógrafos compreender essa inserção por meio da divisão internacional do trabalho, a qual é imbricada no papel geopolítico desempenhado pelos países.

A ida de brasileiros para Portugal a partir do fim do século $X X$ é enfatizada identificando-se as circunstâncias internas em ambos os países que o geraram. Tais circunstâncias expressam a totalidade maior que é o período atual, denominado também de globalização. Assim, o fluxo que aqui se discute 
em especial é interpretado como componente do sistema complexo que são os territórios e o espaço geográfico contemporâneo.

\subsection{Dois períodos de chegada de portugueses no Brasil}

O trânsito de pessoas entre Brasil e Portugal é marcado por dois períodos em que prevalecem os fluxos da ex-metrópole para a ex-colônia. Assim, tradicionalmente, desde a independência do Brasil até meados dos anos 1970, é muito superior o número de portugueses que chegam ao Brasil do que o número de brasileiros que chegam a Portugal. $O$ deslocamento de pessoas entre esses países foi acompanhando as novas dinâmicas do espaço geográfico, como um elemento que, imbricado aos demais, compõem esse sistema. Analisa-se aqui as transformações dos conteúdos do fluxo de portugueses para o Brasil.

\subsubsection{Até meados do século $\mathrm{XX}$ : de lá pra cá}

O primeiro período aqui identificado caracteriza-se pela maior intensidade da vinda de portugueses ao Brasil comparativamente ao fluxo no sentido contrário, o qual era bastante restrito. Essa situação perdurou durante séculos, remetendo às grandes navegações do século XVI.

Em todo esse período, o mundo conheceu importantes inovações técnicas que repercutiram também nos meios de transporte e comunicação, culminando em migrações bastante volumosas. A revolução dos transportes marítimos, que marcou o fim século XV e início do século $X V I$, permitiu que portugueses e espanhóis cruzassem o Atlântico e iniciassem a colonização do continente americano, a qual só foi possível em virtude da migração de significativo contingente de suas populações.

Posteriormente, as Revoluções Industriais também impactaram os meios de transporte e comunicação. A navegação a vapor permitiu a diminuição do tempo das viagens e colocou a Inglaterra na dianteira do processo de difusão dos europeus pelo mundo. Na segunda metade do século XIX, a estrada de ferro e os avanços nos meios de comunicação como os telégrafos e os correios 
permitiram ainda maior mobilidade de pessoas no espaço geográfico. Sobre esse período afirma Hobsbawn (1996):

\begin{abstract}
"A metade do século XIX marca o começo da maior migração de povos da História. Seus detalhes exatos mal podem ser medidos, pois as estatísticas oficiais, tais como eram feitas então, não conseguem capturar todos os movimentos de homens e mulheres dentro dos países ou entre Estados (...) Entretanto, uma forma dramática dessa migração pode ser aproximadamente documentada. Entre 1846 e 1875, uma quantidade bem superior a 9 milhões de pessoas deixou a Europa, e a grande maioria seguiu para os Estados Unidos. Isso equivalia a mais de quatro vezes a população de Londres em 1851. No meio século precedente, tal movimentação não deve ter sido superior a 1,5 milhão de pessoas no todo" (271-272).
\end{abstract}

Como se sabe, o grande lócus dessas transformações técnicas era 0 continente europeu, o qual até meados do século $X X$, também se destacava como origem dos principais fluxos migratórios que se direcionavam ao continente americano, à África, Ásia e Oceania. Cabe mencionar que em 1900 a população européia representava quase $25 \%$ da população mundial e colaborava intensivamente para a expansão populacional dos povos em todo 0 mundo por meio das migrações (Barata, 2003).

Tal como aponta Bassanezi (1995), no início do século XX a Europa passava por transformações sociodemográficas, enfrentava guerras e via surgir regimes autoritários, tornando-se assim um continente marcado pela emigração ${ }^{1}$. A figura a seguir (Figura 1: A grande migração transatlântica) sintetiza, para esse período, o intenso fluxo de saída de pessoas da Europa que tiveram como destino a outra margem do Atlântico.

Alguns autores, como Singer (1974), interpretam esse momento à luz da relação entre população e recursos disponíveis no território, dessa forma, afirmam existir uma "população excedente", o que explicaria a partida de algumas pessoas da Europa para outros continentes. Convém lembrar que as migrações, desde o século $X V I$ até meados do século $X X$ se deram em um quadro de busca de novas terras para garantir riquezas e recursos ao país.

No decorrer desse período, as migrações foram passando de um contexto de imperialismo, cuja marca principal assenta-se nas relações entre as metrópoles e suas respectivas colônias, para um mundo de Estados

\footnotetext{
1 Uma breve e interessante análise da evolução das migrações no decorrer da história pode ser observada em Programa das Nações Unidas para o Desenvolvimento (PNUD). Relatório de Desenvolvimento Humano 2009. Ultrapassar Barreiras: Mobilidade e Desenvolvimento Humanos. Coimbra: Edições Almedina, 2009.
} 
nacionais. As metrópoles constituíam-se, em suma, como áreas de origem dos fluxos migratórios, enquanto as colônias, por sua vez, destacavam-se como áreas receptoras. Mesmo com as independências, esse padrão manteve-se pouco alterado.

\section{Figura 1: A Grande Migração Transatlântica}

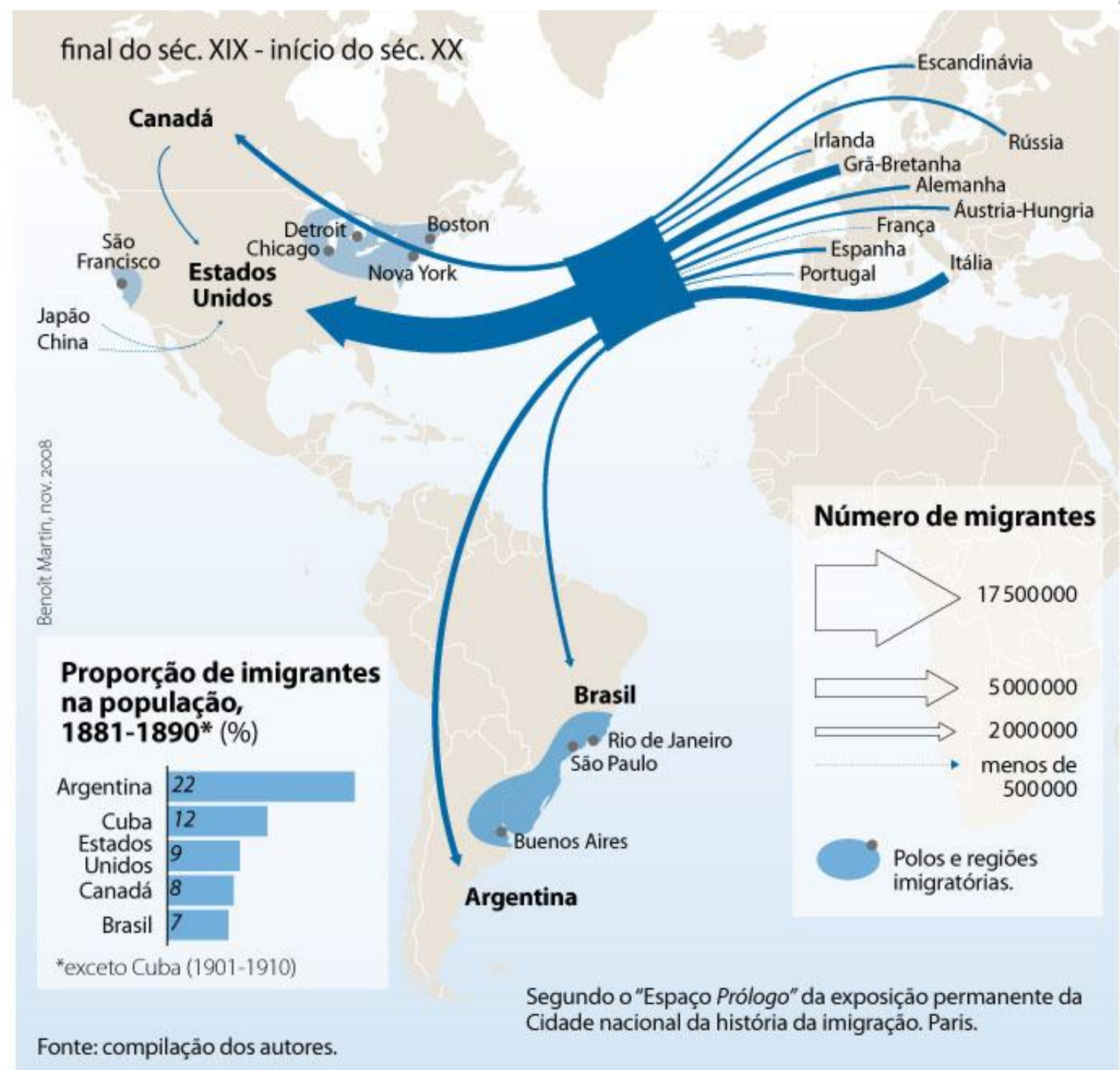

Fonte: DURAND, Marie Françoise (et alli). Atlas da Mundialização, dossiê especial Brasil. São Paulo: Editora Saraiva, 2009. Disponível em www.sciences-po.fr/cartographie (acesso em 06/05/2009)

Como se pode observar acima, Portugal contribui para essa grande migração que caracterizou o fim do século XIX. Entretanto, sua história extra-européia e de contato com diferentes povos data de épocas mais remotas.

A partir do século XVI a colonização portuguesa na África, na Ásia e na América teve fortes repercussões demográficas. Merece destaque a solidificação da emigração como elemento estrutural da sociedade portuquesa por, pelo menos, quatro séculos. 
Diante disso, pode-se afirmar que o caso português constitui uma verdadeira diáspora. Ao contrário do caso brasileiro ${ }^{2}$, Portugal satisfaz todos os elementos expressos na definição desse conceito:

\begin{abstract}
"Dispersão de parte significativa de uma população, originariamente concentrada num dado espaço cultural/nacional, por diversas regiões do globo, afastadas do território referido. Mais ainda, pressupõe que essa dispersão se mantenha para além da vida de algumas gerações e que, a despeito disso, esses grupos ou comunidades de expatriados continue a manifestar o propósito de se identificar com a origem nacional dos seus antepassados e a tornar como referência alguns dos traços que Ihe são característicos" (Rocha-Trindade, 1995: 142).
\end{abstract}

É principalmente com o início da colonização do Brasil que o fenômeno da emigração adquire relevância sem precedentes em Portugal e torna-se permanente. Embora apresente oscilações conjunturais, como por exemplo, o acréscimo instigado pela descoberta de ouro e diamantes em Minas Gerais, ou o decréscimo no contexto das duas grandes guerras, e diferentes formas ao longo do tempo como a de conquista, de colonização ou mobilidade de mãode-obra, a emigração destaca-se em um grande período da história portuguesa como a mais importante vertente dos movimentos migratórios desse país, superando os movimentos internos e as imigrações em termos absolutos e relativos (Rocha-Trindade, 1986; Rodrigues, 2009).

Disso resulta a estimativa de que hoje quase $1 / 3$ dos portugueses vivem fora de Portugal. Monumentos distribuídos em todo o país (ver, a seguir, foto 1: Monumento aos emigrantes portugueses); festas dedicadas aos emigrantes, como as do dia 10 de junho, dia de Camões e das Comunidades Portuguesas, ou do dia 13 de agosto, em que ocorre a Peregrinação dos Emigrantes em Fátima; associações de migrantes portugueses espelhadas pelo mundo, como as Casas do Algarve e do Alentejo em Toronto ou a Casa de Portugal em São Paulo. Todos esses elementos revelam a longa tradição criada pelo fenômeno no país.

\footnotetext{
${ }^{2}$ É possível encontrar menções à emigração brasileira como diáspora, mas trata-se de um uso equivocado do conceito, visto que no Brasil é pequena a porcentagem de emigrados com relação ao total da população e, além disso, trata-se de um fenômeno recente na história do país.
} 


\section{Foto 1: Monumento aos emigrantes portugueses}

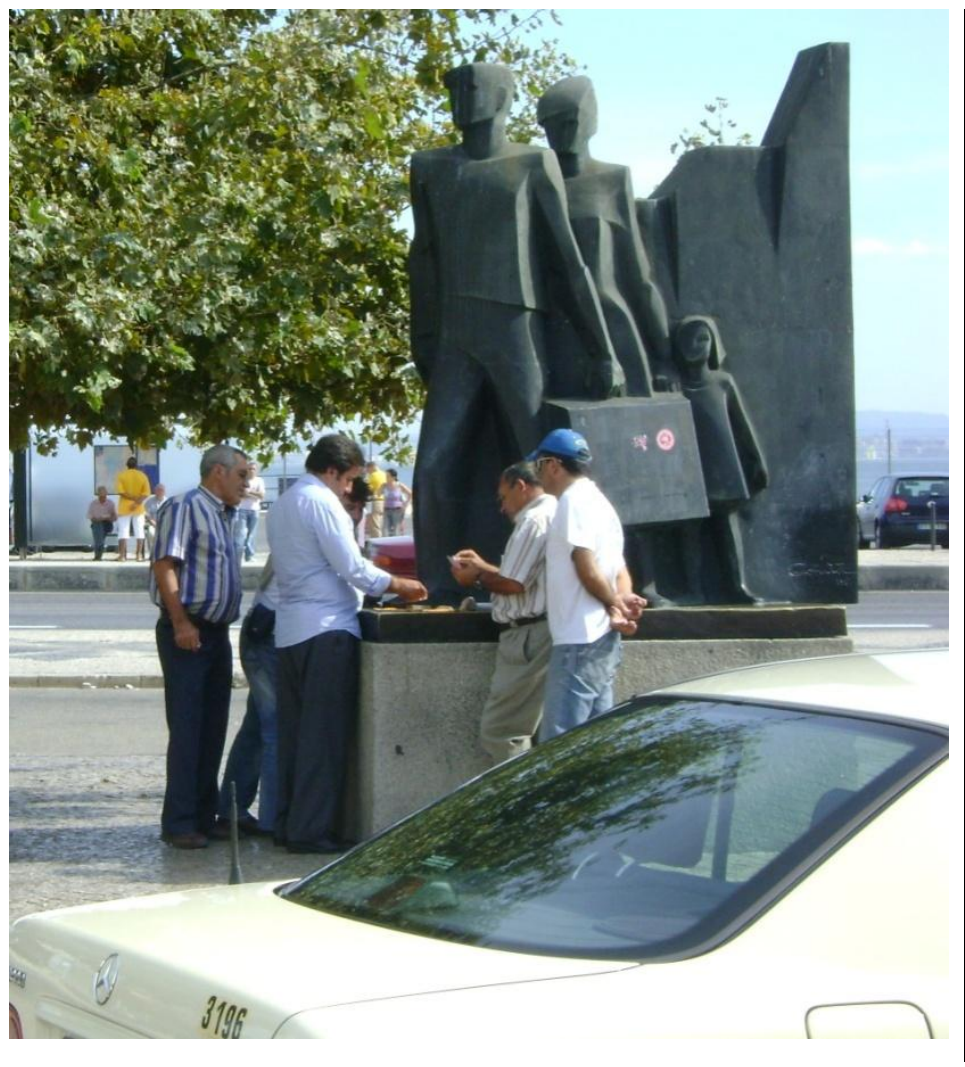

Há muitos monumentos dedicados aos emigrantes em Portugal visando materializar a presença dessa parcela ausente da população. Esse monumento em específico está localizado em frente à Estação de Santa Apolónia, na cidade de Lisboa, uma área de intensa circulação diária de pessoas. Nota-se no monumento um homem carregando uma mala, uma mulher e uma criança, o que traz à lembrança que a diáspora portuguesa envolveu diferentes sexos, idades e famílias.

Foto: Aline Lima Santos Local: Lisboa

Data: Outubro de 2009.

Outro registro curioso materialmente presente no espaço geográfico e que expressa a importância das emigrações em Portugal refere-se às chamadas casas dos emigrantes. Essas casas foram construídas segundo um novo padrão arquitetônico, estético e técnico, diferenciando-se no conjunto da paisagem. Simbolicamente essas casas expressam que a emigração era acompanhada pela adoção de novos valores, comportamentos e crenças. Os portugueses que as construíam em seu lugar de origem deixavam a marca do país onde viveram, ou viviam, buscando evidenciar uma vida dividida entre lugares distantes ${ }^{3}$.

\footnotetext{
${ }^{3}$ Os audiogramas e vídeos que compõem os materiais do curso Sociologia das Migrações da Universidade Aberta, organizado pela Profa. Maria Beatriz da Rocha-Trindade oferecem valiosas elucidações a esse respeito.
} 


\section{Foto 2: Casa de emigrante}

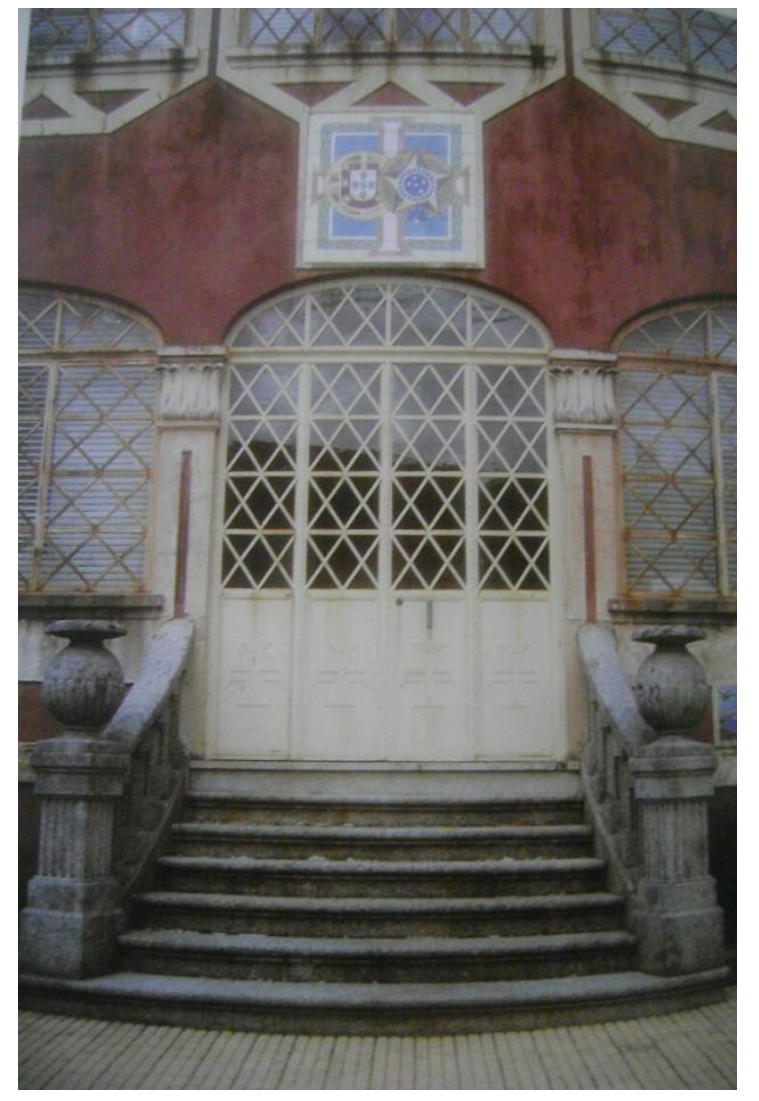

A entrada da casa de Alexandre Rodrigues, que emigrou para o Brasil ainda jovem, ostenta os brasões português e brasileiro, expressando sua condição de migrante. Condição essa dividida. Nas palavras de Miguel Torga:

"Português no Brasil, brasileiro em Portugal, o emigrante fica sem pátria, tendo duas. (...) E o remédio é oscilar, hesitar, sofrer. Gemer por Portugal no Brasil, e pelo Brasil em Portugal" (Traço de União, 1955)

Essa é uma das tantas casas de emigrantes presentes tanto nas áreas rurais como nas áreas urbanas portuguesas.

Foto: Rocha-Trindade \& Caeiro, 2000: 84. Local: São Paio de Gramaços (Oliveira do Hospital)

Na análise das emigrações Rocha-Trindade (2001) identifica três fases: o ciclo clássico, o ciclo moderno e o ciclo contemporâneo. O primeiro ciclo vai do século $X V I$ até meados do século $X X$. É caracterizado pela emigração de longa distância, primordialmente transoceânica. O Brasil manteve-se como destino principal por todo o período, inclusive depois da independência. Prado Jr. (2004) explica que:

"Uma parcela apreciável de sua riqueza (de Portugal) ainda derivará direta ou indiretamente da ex-colônia, seja pelas remessas de seus nacionais ali residentes, seja pelo retorno de tantos que fazem fortuna no Brasil. Além disto, o Brasil será ainda, como foi sempre no passado, uma "carreira" para o português. Entre as alternativas que se apresentam a ele quando escolhe seu meio de vida, o Brasil tem sempre seu lugar. Se o prefere, chamar-se-á brasileiro, como se chamaria vendeiro se preferisse uma venda, ou merceeiro, se fosse para a mercearia. A idéia de "negócio" ligado à antiga colônia, de tão fundas raízes históricas (...) não sairá do espírito do português" (236). 
Os portugueses que escolheram fazer do Brasil um meio de vida tornaram-se aí a comunidade estrangeira mais numerosa, chegando a representar $57 \%$ do total de imigrantes no período de 1875 a 1914 . Eram majoritariamente originários do norte do país, como é possível observar na figura a seguir:

Figura 2: Emigração portuguesa por distrito de naturalidade

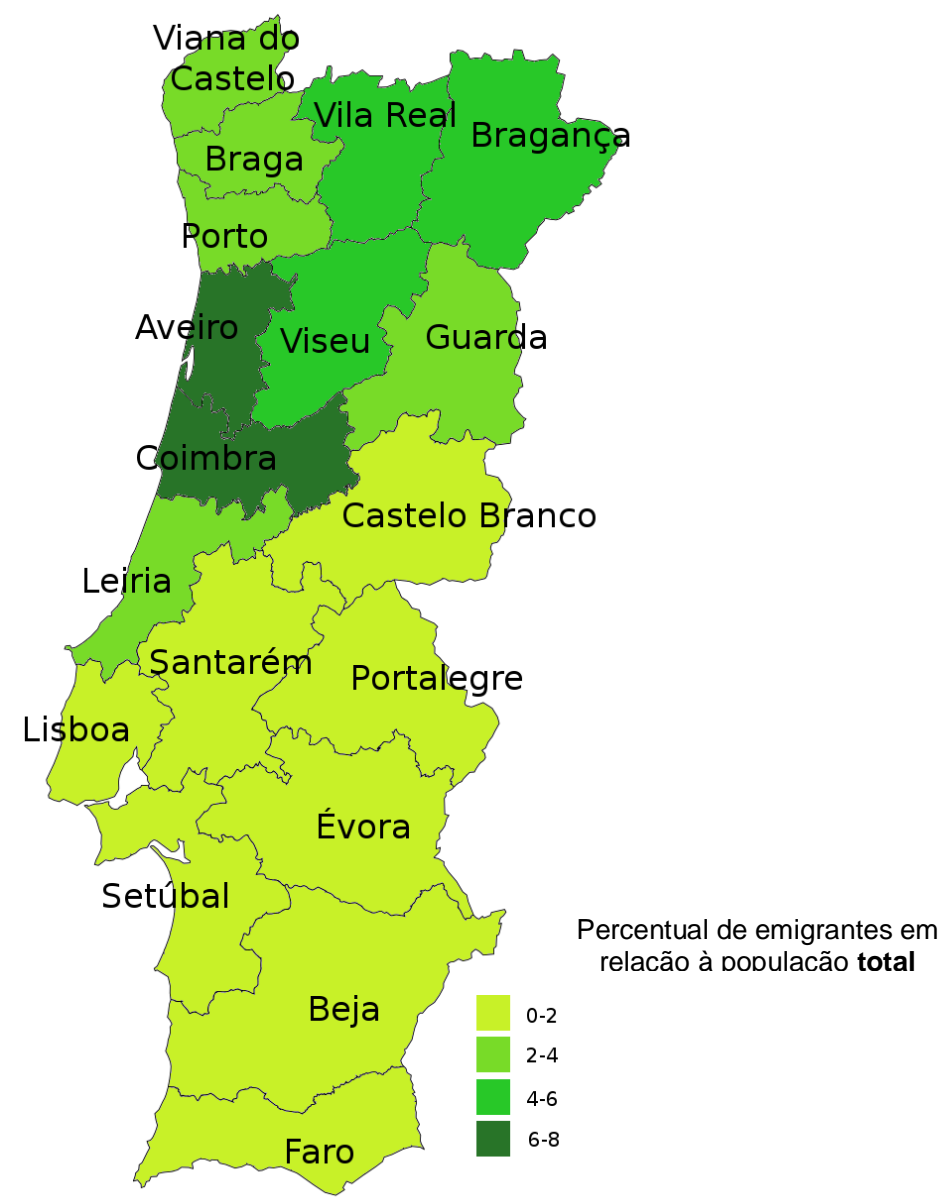

Fonte: ROCHA-TRINDADE, Maria Beatriz \& CAEIRO, Domingos. Portugal - Brasil. Migrações e migrantes. 1850 1930. Lisboa: Edições INAPA, 2000.

Elaboração: Germano de Castro Granda Neto

De modo geral, a perspectiva de ascensão social e econômica era o que motivava a saída de portugueses de sua terra-natal. Em importância numérica, o fluxo para o Brasil era seguido pelo que se dirigia aos Estados Unidos. Em menor grau ainda merecem menção a ida de portugueses para a Argentina e Havaí. Como tendência geral, das pessoas que deixaram Portugal nesse período, a maioria permaneceu definitivamente no país de acolhimento. 
Havia exceções, contudo, que alimentavam ainda mais as saídas: são os que retornavam de experiências migratórias consideradas bem sucedidas em virtude de enriquecimento. O caso dos "brasileiros de torna-viagem", ou apenas "brasileiros" merece alusão.

Tratam-se fundamentalmente de portugueses que retornavam do Brasil demonstrando seu sucesso econômico e ascensão social. Eram, sobretudo, pessoas saídas da pobreza, sem instrução, que alcançaram novo lugar na hierarquia social por meio da emigração. Por isso, esses retornados eram vistos pelas elites portuguesas como ignorantes, mal-educados, arrogantes, e outros muitos juízos de valor negativos ${ }^{4}$. Ainda assim, sua presença de volta a Portugal colaborava para novas emigrações, pois evidenciavam as possibilidades de sucesso.

Enquanto isso os países receptores adotavam políticas incentivadoras da imigração com objetivos diversos, dentre eles, satisfazer as necessidades de mão-de-obra, chegando a responsabilizar-se pelos custos de viagens, por exemplo. Esse é o caso brasileiro.

Quando se discute a inserção deste país nas migrações internacionais podem-se identificar pelo menos três grandes períodos. O primeiro é basicamente um período de fluxos migratórios direcionados para o Brasil. Desde 1822 até a década de 1930, o país recebeu uma grande quantidade de migrantes, principalmente europeus e asiáticos (japoneses), com incentivo do Estado.

A primeira metade do século XIX caracteriza-se pela formação de Estados Nacionais na América Latina. Apenas a partir da constituição do Estado Nacional é que se pode falar de uma sociedade e um território considerados de modo indissociável, em constante movimento e que definem o Brasil enquanto país. Porém, as heranças do período colonial da história brasileira são evidentes em todas as instâncias da sociedade.

A independência em relação a Portugal significou profunda alteração na condição política do Brasil, que deixa a condição de colônia para tornar-se país. Essa mudança baliza o início do primeiro período. Todavia, ela deve ser

\footnotetext{
${ }^{4}$ A visão negativa com relação aos retornados do Brasil é verificada, por exemplo, na obra de Camilo Castelo Branco, em caricaturas, em artigos de jornais da época. Mais detalhes sobre a visão da elite portuguesa com relação aos "brasileiros" podem ser encontrados no capítulo 6 do livro ROCHA-TRINDADE, Maria Beatriz \& CAEIRO, Domingos. Portugal - Brasil. Migrações e migrantes. 1850 - 1930. Lisboa: Edições INAPA, 2000.
} 
encarada não apenas como marco, mas como um processo, no qual, como nos mostra Prado Jr. (1977), a transferência da corte portuguesa para o Brasil em 1808 e os interesses da elite latifundiária e comercial formam as bases para a autonomia brasileira. Tal autonomia tornou-se efetiva com o fim completo das restrições coloniais ocorrida em 1822. Este fato abriu maiores possibilidades de inversões e de comércio, além de explicar os fluxos migratórios dirigidos ao Brasil a partir dessa fase.

Posteriormente, ainda no primeiro período, da segunda metade do século XIX em diante, o fim da escravidão, a expansão da lavoura cafeeira e a adoção de políticas que visavam consolidar o país enquanto nação moderna elucida porque houve incentivo à imigração por parte do Estado. Singer (1974) identifica três fatores que conjugados explicam a imigração européia no Brasil:

"1. o avanço do capitalismo na Europa, produzindo um excedente populacional, por parte do qual se vê obrigado a emigrar. 2. O surgimento de interesses capitalistas no financiamentos da colonização de áreas de países "novos" por esses imigrantes. 3. A aparição, em países de economia colonial, da consciência da necessidade de diversificar seus sistemas produtivos, de modo a escapar da dependência econômica em que se encontravam" (p. 154).

O Brasil recebeu neste período aproximadamente cinco milhões de imigrantes, especialmente europeus. Os estrangeiros eram provenientes, principalmente de Portugal, Itália, Espanha, Alemanha, Japão e outros, os quais responderam no período de 1872 a 1972 por 31\%, 30\%, 13\%, 4\%, 4,6\% e $16 \%$, respectivamente, do total de pessoas que vieram residir no país (Bassanezi, 1995).

Essa imigração respondia a necessidade de construir uma classe média, incrementava a incipiente urbanização e inseria na sociedade novas formas de consumo, como a demanda por escolas. Além disso, "possibilitava" o branqueamento da população brasileira, o que era visto pela elite e por intelectuais da época como condição para o progresso, Paiva (2004) afirma:

"Na avaliação de alguns dos intelectuais do período, grande parte da população brasileira era de origem miscigenada: uma sociedade híbrida, composta de mestiços, negros e brancos não configurava a estabilidade que, se supunha, era peculiar às sociedades homogêneas (...). A imigração européia (..) também era vista como caminho para colocar o Brasil no padrão eugênico dos países considerados avançados. Ao mesmo tempo, o desenvolvimento econômico paulista, capitaneado pela cafeicultura, foi 
associado ao resultado concreto do esforço do trabalhador imigrante. As elites locais construíram uma imagem de São Paulo como pátria dos italianos, espanhóis, portugueses, alemães... Reedita-se no plano regional uma noção de superioridade frente às outras regiões do país" (p.232)

A partir de 1910 houve diminuição dos fluxos migratórios para o Brasil e uma valorização do trabalhador nacional, a qual foi acompanhada por uma "representação desqualificadora do Nordeste como lugar de fracasso, da miséria, inviabilidade do desenvolvimento" e valorização de São Paulo como locomotiva, "espaço de acolhimento e generosidade com o outro" (Paiva, 2004: p.11). O Nordeste tornou-se, portanto, o celeiro de mão-de-obra do país. Esse processo caracterizou o fim do primeiro período de migrações no Brasil e anunciava o período seguinte, mas não só, já que esboçava igualmente o fim do primeiro período de migrações de portugueses para o Brasil.

\subsubsection{Meados do século XX a 1980: uma transição}

No segundo período dos movimentos migratórios entre Brasil e Portugal a entrada de portugueses no Brasil continuava superando o movimento contrário, mas a sua queda era uma tendência explícita. Tal fato permite qualificá-lo como um período de transição.

Justamente por constituir-se numa transição, não há muita precisão no estabelecimento do início e fim desse período, bem como não houve a preocupação de se apontar um marco para o término do período anterior. Para melhor compreender, interessa um olhar mais atento às periodizações específicas adotadas para cada um dos países.

A partir da década de 1930, o Brasil foi marcado por diminuição das imigrações de estrangeiros e aumento das migrações internas, tanto interregionais, como rural-urbana. Em suma trata-se de um momento de maior relevância dos movimentos populacionais no interior do território brasileiro.

No primeiro e no segundo período a migração foi incentivada pelo Estado para a criação de um Brasil moderno. Todavia, muda-se a tipologia dessa mobilidade, passa-se do estímulo das migrações internacionais às migrações internas.

Isso se relaciona tanto à expansão cafeeira como ao impulso dado à industrialização brasileira, a qual foi intensificada após a crise de 1929 e 
ganhou ainda mais força a partir de 1950. Além disso, recebeu fortes influências de um novo ideal político, marcado pela reprovação explícita ao liberalismo econômico republicano e pela necessidade de construção de uma nação homogênea e coesa, em detrimento de uma nação de regionalismos baseados na composição étnica que vinham ocorrendo até então no sul e sudeste do país. (lanni, 1977; Paiva, 2004)

A idéia de que a industrialização desembocaria em crescimento e conseqüente desenvolvimento econômico influenciou grandemente os intelectuais e estadistas da época (Bielschowsky, 1996). Marca essa fase as políticas de substituição de importações e a construção de grandes obras de engenharia, com financiamento externo, especialmente 0 capital norteamericano. Destaca-se o Plano de Metas do governo JK como um dos símbolos dessa lógica desenvolvimentista. O território brasileiro ganhou novo conteúdo técnico, a indústria o remodelou, conferindo-lhe uma nova organização não mais assentada nas bases agrário-exportadora.

O impulso dado por esses investimentos à economia brasileira era concentrado em poucas áreas do território, daí decorre o aprofundamento das desigualdades regionais e sociais. São Paulo reafirma primazia que vinha sendo gestada em período anterior. As áreas mais beneficiadas por essas políticas acabaram por coincidir com as de atração das pessoas provenientes das áreas mais carentes de investimentos.

Cabe salientar o aumento de número de cidades e adensamento das já existentes em decorrência do êxodo rural, conseqüente, dentre outros fatores, da intensificação do desenvolvimento capitalista no campo, do Estatuto do Trabalhador Rural e do Estatuto da Terra. A ida para a cidade significava a possibilidade de ascender socialmente.

Nesse período percebe-se o crescimento de uma classe média ligada ao setor industrial no Brasil, mas igualmente se nota a produção de uma periferia pobre nas cidades. Sobre esses desdobramentos na estrutura social brasileira, lanni (1977) afirma:

"Em conseqüência da incipiente industrialização havida nas décadas anteriores, do crescimento do setor terciário e da própria urbanização, surgiram novos grupos sociais, particularmente os primeiros núcleos 
proletários e os princípios da burguesia industrial, além de expandir-se bastante a classe média" (p.17).

De modo geral, conforme já assinalado, nesse período o país pouco contribuiu na circulação internacional de pessoas. Isso não significa, porém, inexistência dos fluxos. Durante os governos militares, houve, por exemplo, uma emigração cuja motivação foi política. Contudo, sua expressividade numérica era pequena. Os poucos imigrantes que chegaram a partir da década de 1930, são provenientes, sobretudo, de Portugal.

Nessa fase, todavia, a imigração já não contava com o incentivo estatal. Mas o dinamismo econômico brasileiro, os laços históricos culturais, a durabilidade temporal do fluxo, a má situação política da Europa de modo geral, e de Portugal em particular, que passava pelo surgimento da ditadura de Salazar, são elementos que motivavam a migração de portugueses.

Comparando os momentos vividos pelos dois países no que se refere aos movimentos populacionais, o Brasil estava em um novo período, enquanto Portugal não. Uma transformação considerável iria ocorrer nesse país somente com o fim da Segunda Guerra Mundial.

A partir da segunda metade do século XX emergiu um novo período das emigrações portuguesas, que perduraria por cerca de 20 anos. O ciclo moderno iniciou-se com o fim da Segunda Guerra Mundial e teve em seu fundamento a ajuda econômica oferecida pelo Plano Marshall para reconstrução dos países europeus que foram destruídos pela guerra (RochaTrindade, 2001). A Europa conheceu a partir de então elevado dinamismo econômico, o que fez mudar a direção dos fluxos de emigração portugueses, os quais deixaram o além-atlântico para voltarem-se ao interior do continente europeu.

A França foi o país que mais recebeu portugueses no mundo em 1963, tomando a posição histórica do Brasil. Alemanha, Luxemburgo, Suíça, Bélgica, Holanda e Grã-Bretanha também se configuraram como importantes destinos (Rocha-Trindade, 2001). Nesse período a tendência à permanência perdeu a força, enquanto aumentou os casos de retorno ou visitas assíduas a Portugal, pois os percursos eram mais próximos, baratos e rápidos. 
No ciclo moderno das emigrações portuguesas verifica-se mais complexidade, o que se manifesta na diversificação dos destinos extraeuropeus. As emigrações transoceânicas não desapareceram, mas retraíramse e conheceram novos destinos, direcionado-se também à África (África do Sul, Angola e Moçambique), à Venezuela e o Canadá (Rocha-Trindade, 2001).

O padrão migratório mundial sofreu profundas alterações depois de 1945 e os fluxos que partiam de Portugal explicitam bem isso. Os investimentos na reconstrução da Europa e o grande dinamismo econômico daí decorrente, bem como a consolidação do Estado do Bem Estar Social, acabaram por atrair mão de obra estrangeira.

Isso ocorreu, sobretudo, nos países que se envolveram mais diretamente na guerra recém-terminada. Não era o caso português, o qual ocupava posição periférica no continente, fato que era tanto uma vantagem, uma vez que não participou dos horrores da guerra em seu território, como uma desvantagem, pois, em vista disso, não usufruiu diretamente dos recursos do Plano Marshall.

Mas, além da adoção de um Estado do Bem Estar Social nos países do norte, as décadas subseqüentes ao fim da Segunda Guerra Mundial foram marcadas pelo processo de descolonização na África e Ásia, rápido crescimento populacional dos países pobres e um conseqüente temor de uma "invasão terceiro mundista" decorrente de uma provável migração maciça de pessoas vindas de países pobres. Como nos mostra Santos (2008):

"Após a Segunda Guerra Mundial, há tendência à inversão das correntes migratórias (...). Largos contingentes de população se deslocam de países vizinhos mais pobres da Europa e, mais tarde, de antigos países coloniais. O outro lado da colonização é a colorização da Europa" (p. 45).

Tais fatores explicam o cerceamento às migrações, muito embora os Estados tentem controlá-las de acordo com interesses e conjunturas específicas. Nas décadas de 1950-60, por exemplo, a França incentivou a entrada de migrantes para trabalhar na sua reconstrução.

No entanto, em circunstâncias de crise, geralmente, proliferam argumentos contrários às imigrações nas mais diversas instâncias sociais. Os migrantes passam a ser vistos como uma ameaça à manutenção do Estado do Bem Estar Social, o qual se apresenta fragilizado, e, frequentemente, passam a 
ser alvos de atitudes xenófobas nas sociedades receptoras e de políticas mais restritivas no que tange à imigração. Com a crise do petróleo, em 1973, por exemplo, a França passou a restringir a entrada dos migrantes, o que certamente repercutiu na comunidade portuguesa aí presente.

Todos esses processos sociais, populacionais, econômicos, geopolíticos, que iniciaram na segunda metade do século $X X$ tomados em conjunto, indicam a emergência de um novo período da história da humanidade, o período técnico-científico, também denominado globalização, que vai atingir mais efetivamente os países pobres apenas a partir da década de 1970. Os processos que levaram à sua consolidação e aprofundamento em todo o planeta tiveram repercussões na tradicional mobilidade de pessoas entre Brasil e Portugal, como já é anunciado nesse período de transição que aqui se discutiu, o qual culminará na situação atual.

\subsection{De 1980 em diante uma inversão: daqui pra lá}

O Brasil é um dos poucos países no mundo em que há certo equilíbrio entre imigração e emigração, já Portugal apresenta saldo migratório positivo. Em ambos os casos, o que se nota é a transformação de uma característica secular, em que o Brasil era qualificado como país de imigração e Portugal como país de emigração. Evidentemente, esta mudança é sintoma de inúmeras transformações pelas quais estes países e o mundo passaram em um período recente de sua história. Tais transformações ultrapassam as explicações demográficas e econômicas isoladas. Cabe, portanto, identificá-las e analisálas.

Inicia-se pela configuração atual dos fluxos migratórios. Há maior quantidade de pessoas que se deslocam no interior do próprio país do que as que cruzam fronteiras nacionais. Estima-se que existam atualmente 740 milhões de migrantes internos no mundo, isto é, quase quatro vezes o volume das migrações internacionais, porém não se pode negar a importância dessas últimas hoje.

Essa importância advém não tanto da proporção do número de migrantes internacionais na população mundial, pois alguns cálculos permitem 
inferir que ela encontra-se em valores equivalentes aos do início do século $X X$ (PNUD, 2009). Mas os seus significados trazem novidades, o que se verifica, por exemplo, nos seus novos conteúdos políticos, na nova seletividade e direcionamento dos fluxos.

As imigrações deixaram de ser desejadas, tais como eram no primeiro período aqui tratado, e países que historicamente apresentavam saldo migratório negativo passam a apresentá-lo positivo. Em contrapartida, muitos países caracterizados pelo saldo migratório positivo, passam a perder pessoas. Brasil e Portugal conheceram a partir da década de 1980 tais alterações, os fluxos existentes inverteram-se. Desde então, mais brasileiros migram para Portugal do que o contrário, como ocorria anteriormente.

Esse novo direcionamento do sentido do fluxo em questão está em consonância com os elementos que distinguem o período atual dos movimentos populacionais mundiais. A figura 2 (Principais movimentos migratórios, situação em 2005) representa a situação dos movimentos migratórios no ano de 2005. A comparação entre as figuras 1 (A grande migração transatlântica) e 2 mostra que as migrações sentido sul-norte são um fato relativamente recente na história das migrações, iniciado com o fim da Segunda Guerra Mundial, como já mencionado.

De maneira geral, a figura 2 revela que as regiões mais ricas apresentam maior porcentagem de população imigrante no total da população residente. Conforme estimativas da Organização das Nações Unidas (ONU) referentes a 2010 , quase $60 \%$ dos migrantes no mundo estabeleceram-se em países ricos. O continente europeu concentra sozinho mais de $30 \%$ deles, isto é, aproximadamente 69189282 pessoas. Na América do Norte a porcentagem é de 23,5\%, ou seja, 50042408 pessoas.

Em contrapartida, os países pobres concentram pequena proporção do total de imigrantes no mundo: a África destaca-se com maior peso: 9\% e a América Latina e o Caribe, considerados conjuntamente, concentram 3,5\%. A Ásia apresenta quase $29 \%$ desse total, o que em termos absolutos refere-se a 61323979 imigrantes e a Oceania, 3\%, ou seja, 6014693 estrangeiros. (United Nations, 2009). 
Figura 3: Principais Movimentos Migratórios, situação em 2005

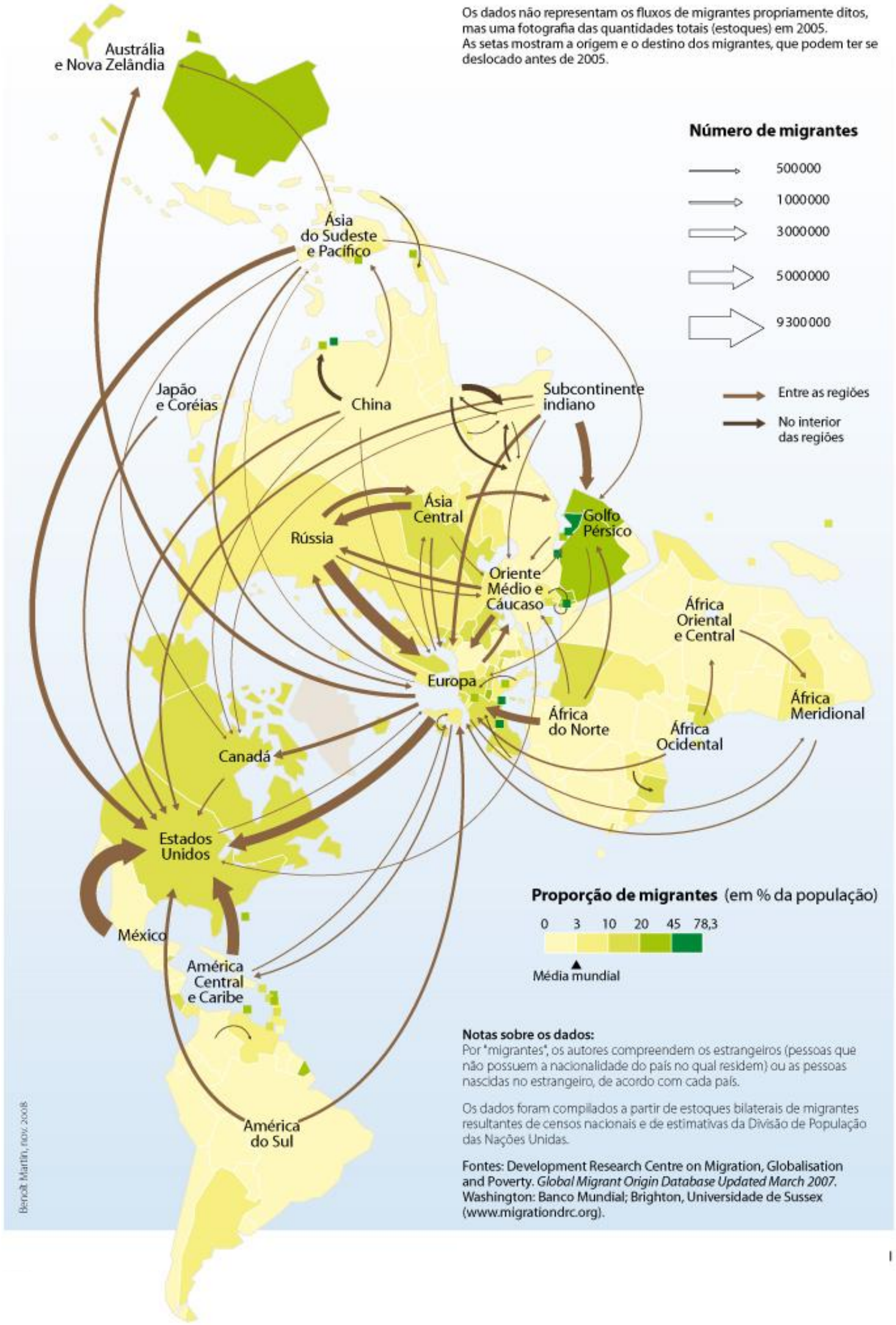

Fonte: DURAND, Marie Françoise (et alli). Atlas da Mundialização, dossiê especial Brasil. São Paulo: Editora Saraiva, 2009. Disponível em www.sciences-po.fr/cartographie (acesso em 06/05/2009) 
Esse é o panorama quando se enfatiza os estoques nos países receptores. Mas considerar a amplitude do fenômeno migratório atual exige igualmente observar de onde partem os fluxos, caso contrário é possível ficar com a impressão errônea de que numericamente os principais fluxos migratórios da atualidade são aqueles que saem de países do sul e tem como destino os países do norte. Quando na realidade:

"Entre as pessoas que se deslocaram atravessando fronteiras nacionais, pouco mais de um terço mudaram-se de um país em desenvolvimento para um país desenvolvido - menos de 70 milhões de pessoas. A maioria dos 200 milhões de migrantes internacionais do mundo mudou-se de um país em desenvolvimento para outro, ou entre países desenvolvidos". (PNUD, 2009: p.2)

As migrações no interior das regiões supranacionais são bastante representativas. Além disso, os deslocamentos de pessoas entre países fronteiriços merecem destaque, dado sua importância no conjunto. A circulação de pessoas entre os países da Ásia, por exemplo, supera a soma dos fluxos provenientes de outras regiões que chegam a Europa. Esse movimento no interior da Ásia responde sozinho por quase $20 \%$ das migrações no mundo. Outro exemplo é a África, embora habitualmente se enfatize os fluxos que daí parte para Europa, esses correspondem a pouco menos de $1 \%$ do total de emigrantes africanos. O esquema abaixo sintetiza essa situação atual dos fluxos migratórios internacionais.

\section{Esquema 1: Migrações internacionais no mundo atual}

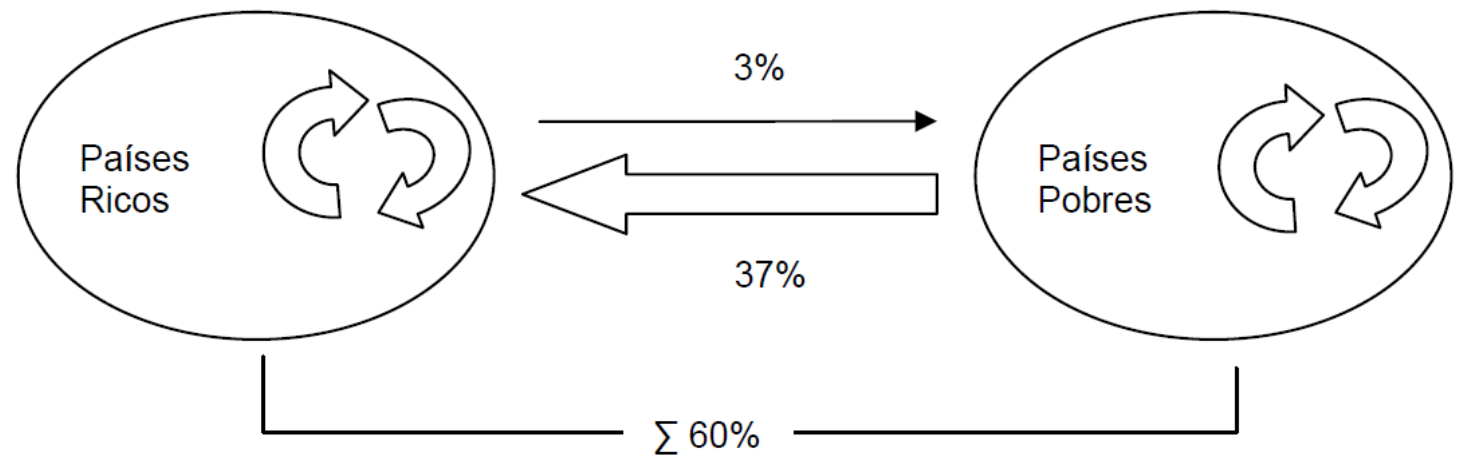

Fonte: PNUD. Relatório de Desenvolvimento Humano 2009. Ultrapassar Barreiras: Mobilidade e Desenvolvimento Humanos. Coimbra: Edições Almedina, 2009. 
Dada a heterogeneidade dos territórios, característica do espaço geográfico contemporâneo, esses movimentos se enquadram em diferentes situações, pois ocorrem em meios diferenciados entre si do ponto de vista técnico, por exemplo. Tal diferenciação resulta de que as técnicas atuais não se encontram difundidas de maneira homogênea. Sua difusão se dá seletivamente e é fruto de escolhas políticas realizadas por diferentes atores sociais em diversas escalas geográficas.

Uma das situações que se verifica é, conseqüentemente, um movimento caracterizado por pessoas com níveis econômico, técnico e tecnológico melhores, que se deslocam para um meio cujas características técnicas, tecnológicas e econômicas são piores. Uma novidade dessa migração no período atual é que geralmente esses migrantes representam grandes empresas, por conseguinte, técnicas e capitais importados, o que influencia suas relações e seus comportamentos no país de acolhimento.

Outra situação que merece destaque é oposta a anterior, isto é, pessoas que se deslocam para um meio cujas características técnicas, tecnológicas e econômicas são melhores (Santos, 2004). Ambos esses tipos de migração estão associados, pois se encontram inseridos no mesmo sistema: o espaço geográfico globalizado.

Daí a importância de se deter à atuação das grandes empresas atualmente, visto que se tratam de grandes atores globais, talvez os mais importantes, capazes de reorganizar o espaço geográfico, aprofundando o processo de globalização. Tais empresas agem valendo-se do aproveitamento das virtudes dos lugares. Essas virtudes acabam por definir o papel dos lugares na divisão internacional do trabalho. Nas palavras de Bacelar (2008):

"Os agentes globais, que comandam o processo, escolhem os lugares em função do cruzamento de duas variáveis. Seus próprios objetivos e os atributos dos lugares. É por isso que ao contrário do que a palavra sugere, a globalização é um processo seletivo, gerador de desigualdade. Os agentes que realmente decidem abrem o mapa-múndi e escolhem onde vão crescer, onde vão se consorciar, de onde vão sair: a escolha é deles de acordo com seus objetivos estratégicos e dos atributos de cada território. Eles vão para determinados lugares e não vão para outros. Há lugares muito engatados na dinâmica global e outros bem menos. A globalização, portanto, é um processo que não anula as hierarquias, mas as recria" (p.9). 
Sassen (2003), preocupada em analisar as cidades globais, atenta às ações das grandes empresas elencando o investimento estrangeiro direto (IED) como variável chave, destacando sua relevância na análise das migrações. Segundo essa socióloga "la inversión extranjera (...) contribuye al desarrollo de vínculos econômicos, culturales e ideológicos con los países industrializados. Estos vínculos tienden a promover la noción de emigración tanto directa como indirectamente" (p.76).

Os IEDs permitem apreender a atuação das empresas multinacionais e transnacionais no mundo. Segundo a CEPAL (1998) "la inversión extranjera directa se ha constituido en un elemento central del proceso de globalización que caracteriza a la economía internacional de finales del siglo veinte" (p.12). A média anual mundial dos IED passou de 142 bilhões entre 1985 e 1990 para 350 bilhões em 1996, fato que evidencia o aumento da importância das empresas transnacionais na maior parte dos países, tanto ricos como pobres (CEPAL, 1998). Além disso, demonstra a maior interdependência entre as economias.

A expansão da atuação das grandes empresas em países pobres é notável quando se compara a participação dos mesmos como destino dos fluxos mundiais de IED: se em 1990 correspondia a $14,9 \%$ do total, em 1996, ultrapassa os 37\%. Do total dos IED, em 1996, 94\% destinaram-se a América Latina (31\%) e Ásia (63\%) (CEPAL, 1998).

Os países da América Latina e do Caribe, no decorrer dos anos 1980 e 1990 realizaram reformas e procuraram manter estabilidade econômica a fim de atrair esses investimentos em virtude da profunda crise econômica que enfrentavam. Essa crise, embora assuma caráter particular em cada país, tem em sua origem a crise do petróleo de 1973, que atingiu profundamente a economia dos Estados Unidos, levando esse país à recessão.

Essa foi combatida por meio de um conjunto de medidas que incluía a pressão para que os países da América Latina e Caribe pagassem as dívidas acumuladas no decorrer da segunda metade do século XX. No caso brasileiro, o ápice da crise econômica decorrente da dívida externa e da falta de financiamento externo, em especial aqueles oriundos dos Estados Unidos, utilizados para as grandes obras públicas de infra-estrutura, pode ser identificado na década de 1980. Conseqüentemente, o modelo 
desenvolvimentista em marcha desde a década de 1930 mostra-se esgotado, o que leva a conturbados reflexos na esfera política, culminando no fim da ditadura militar, cujo último governo durou até 1985.

É especialmente nos anos 1980 que os Estados Unidos passaram a propor e, mesmo, impor à América Latina e Caribe como um todo, abertura econômica e comercial, caracterizando uma política de expansão de seu território em termos de mercado. Difundiram-se no continente americano os mandamentos do Consenso de Washington (1989), expressos aí sob a forma de adoção de políticas neoliberais. Tais políticas acabaram por aprofundar 0 processo de globalização.

As reformas levadas a cabo pelos países pobres do continente americano por meio de políticas neoliberais, visavam, dentre outras coisas, diminuir a dívida externa, diminuir as despesas do Estado, assegurar investimentos estrangeiros e desregulamentar o mercado. $O$ Consenso de Washington previa a implantação de dez pontos os quais, como expõem Martins (2003), culminariam na:

"retomada do desenvolvimento, (n)a elevação da competitividade e (n)a redução da pobreza das economias latino-americanas. As taxas de crescimento econômico voltariam a se elevar, os ingressos de capital estrangeiro se restabeleceriam, o aumento da competição impulsionaria a produtividade das economias nacionais que se especializariam em suas vantagens comparativas, descartando os setores de maiores custos de produção relativos. No entanto, os resultados alcançados foram profundamente medíocres" (p.317).

No caso brasileiro a emigração surge nesse contexto de crise econômica e política seguida de abertura econômica, aumento de IED e "ausência" do Estado. O Estado passa a deixar a política por conta das grandes empresas (Santos, 2001), agindo de acordo com os interesses das mesmas, legitimando sua ação através do discurso da modernização e globalização inevitáveis.

Houve abertura comercial, financeira, tecnológica, produtiva e laboral. $\mathrm{O}$ território usado passou a expressar a lógica das grandes empresas, as quais extrapolam as fronteiras nacionais, fato que ratificou as desigualdades no país.

Dados da CEPAL (2009) sobre os IED no Brasil mostram que dentre os cinco principais países investidores na década de 1999 a 2009 estão os que se destacam como países que mais recebem brasileiros: Estados Unidos e Japão. 
A Alemanha, o Reino Unido, Itália, França e Portugal também tiveram relevância no conjunto dos investimentos realizados desde o princípio da década de 1990 e, igualmente, nota-se a presença brasileira em sua população residente.

Ao analisar a economia das cidades dos países subdesenvolvidos, Santos (2004) destaca também o papel das grandes empresas, enfatizando a organização do território e associando-a as migrações internas. Pode-se extrapolar suas interpretações para as migrações internacionais, considerando mais especificamente um aspecto de seus argumentos: a importância do consumo.

Ao se instalarem nos países pobres, as grandes empresas potencializam as desigualdades no território nacional, aumentam um pouco mais o número de assalariados, alteram o padrão de consumo e produção, que passam a ser copiados dos países ricos (Santos, 2004). O efeito demonstração é ratificado, isto é, a preferência por aquilo que é importado, marca histórica das sociedades dos países subdesenvolvidos, encontra hoje novas roupagens.

O caso brasileiro é exemplar: ao abandonar o projeto nacional de industrialização, que caracterizou o período de 1930 a 1980, o Brasil conheceu uma fase de tentativa de controle da inflação, por meio de planos econômicos tais como o Plano Cruzado, o Plano Collor e o Plano Real. Apenas o último foi bem sucedido nessa tentativa de controle inflacionário. Contudo, seus benefícios esgotaram-se e, tal como afirma Guerra, et alli (2006):

"os custos dessa estabilização corroíam aceleradamente a estrutura produtiva do país e o próprio Estado brasileiro, tudo envolto no silêncio indecente da mídia. (...) As importações tiveram novo salto, competindo desigualmente com a produção nacional. A enxurrada de bens importados a baixos preços diante de um parque industrial nacional tecnologicamente defasado e sem fontes de financiamento ou de inovações foi desastrosa (...)" (p. 52)

O resultado foi a estagnação econômica e o enfraquecimento do parque produtivo brasileiro, o qual foi incapaz de suportar a concorrência externa. Assim como nos demais países pobres, as técnicas altamente poupadoras de mão-de-obra associadas à difusão de grandes corporações acirrou a grande massa de despossuídos e fez a classe média perder poder aquisitivo. Concomitantemente, em todo o mundo, o setor de serviços ganhou importância 
sem precedentes, tanto o altamente qualificado, que alguns denominam como quaternário, como o trabalho informal que abriga os trabalhadores com baixa ou nenhuma formação e qualificação, ou seja, os que estão preocupados com a sobrevivência (Mourão 2005).

A classe média brasileira, então, perde espaço na estrutura social do país, já que no período imediatamente anterior era majoritariamente assalariada e engajada nas atividades industriais, as quais passam a sofrer contração. Se em 1980 a classe média assalariada equivalia a mais de $66 \%$ do total da classe média, em 2000 essa expressão cai para menos de 60\% (Guerra, et alli, 2006).

Um parêntesis se faz necessário: os movimentos migratórios no Brasil sempre estiveram vinculados ao desejo de melhoria da vida material e à ascensão social. Além disso, as migrações para o Brasil e no interior do país contribuíram para formação e consolidação da classe média, as quais tem nesses desejos uma de suas características mais marcantes. Por isso, no passado e no presente, migrações e classe média encontram-se intrinsecamente vinculadas. É justamente essa parcela da população brasileira que mais irá se dispor a sair do país em busca desses desejos.

O enxugamento da classe média assalariada associada ao setor industrial e às instituições públicas é acompanhado pela emergência de um novo perfil, característico de uma sociedade de serviços, em que os contratos se dão de maneira indireta e na esfera das redes de produção mundiais. A "segurança" dos contratos assalariados dá lugar à "informalidade no exercício do trabalho e na crescente auto-ocupação (free lancer, empresa sem empregado, organizações não governamentais, entre outras)" (Guerra, et alli, 2006: p.24).

Este novo perfil no interior da classe média é dotado de valores cosmopolitas e individualistas característicos da fase atual do capitalismo e que acaba por se difundir no grupo como um todo. Mantêm-se os tradicionais desejos de consumo, status social e poder.

Essa desigualdade social e concentração de riquezas é ainda mais perversa quando se leva em conta a primazia do consumo, alimentada pela financeirização da parcela mais pobre da população. $O$ marketing e a 
propaganda difundem um ideal de vida pautado na assertiva de que "ter é ser" e disseminam padrões que não é possível para todos.

O acesso a esse consumo "moderno" é porém limitado, pois nem todos os produtos e bens estão disponíveis em todos os lugares e a todas as pessoas nos países mais pobres, ao contrário dos países ricos, os quais caracterizam-se pela maior acessibilidade ao consumo por parte da população (Santos, 2004). Esse é um dos fundamentos das emigrações nos países pobres, de modo geral e do Brasil em particular, especialmente dos fluxos que se direcionam aos países ricos.

A aspiração do consumo e de um padrão de vida específico é estimulada pela publicidade e pelo marketing. A isso se soma a histórica condição periférica, e atualmente semi-periférica, do Brasil no cenário internacional. Tal condição é responsável por certa postura submissa e subalterna de parcela da sociedade que tende a valorizar o exterior em detrimento do nacional. Colabora para isso a incapacidade de certas empresas nacionais competirem com as grandes empresas no que se refere à qualidade dos produtos que oferecem.

Decorre, então, que a experiência de viver no exterior é repleta de significações positivas no Brasil. Nesse sentido, morar em algum país europeu, nos Estados Unidos, ou em outros países ricos constitui-se na ilusão de maior acesso ao consumo e prestígio social no Brasil, ainda que isso signifique para o migrante, condições de vida piores do que a anterior.

Os elementos precedentes contribuem para a compreensão do aumento da emigração no Brasil. Embora emigrar seja na micro-escala uma ação individual, ela encontra significados amplos quando associada à dinâmica espacial. Há predominância da saída do país de pessoas pertencentes à classe média e tal fato encontra explicações estruturais, econômicos, políticos e psicossociais, tal como se buscou evidenciar acima.

Reiterando, conforme afirma Klagsbrunn (2008), a crise enfrentada pelo país na década de 1980 atingiu duramente a classe média, que conheceu um período de redução de salários, desemprego e desocupação. Mesmo com o Plano Real, em 1994, que obteve êxito no controle da inflação, não houve melhoria nas condições dessa camada da sociedade, pelo contrário, houve 
retração e perda de rendimentos. A falta de perspectiva de melhoria levou a busca por melhoria de condições de vida fora do país. Nas palavras do autor:

"Os poucos estudos disponíveis sobre os migrantes brasileiros para os países desenvolvidos indicam que, em sua maior parte, estavam desempregados ou sub-empregados no Brasil e sobretudo, sem perspectivas de uma inserção com rendimento e status mais elevado na sociedade brasileira. Para as camadas médias a perspectiva de ascender socialmente é um valor e um anseio generalizado. Mesmo quando assalariadas, almejam muitas vezes pelo estudo elou por concursos públicos ascender a condições sociais e econômicas mais favoráveis"(p.01).

A redução de renda atingiu a classe média até 2005, quando daí em diante volta a dar sinais de recuperação. Até esse momento, a falta de perspectiva de melhoria levou a busca por melhoria de condições de vida fora do país.

As repercussões da adoção de políticas de abertura econômica, porém, não trouxeram conseqüências negativas apenas ao Brasil, mas para toda a América Latina e Caribe e outras partes do mundo. No início do século XXI parte significativa dos Estados e sociedades latino americanas buscaram reagir. Emergem assim governos com tendência a priorizar interesses nacionais e o desenvolvimento social, ainda que isso ocorra com limites consideráveis, tendo em vista o enfraquecimento dos Estados verificado no fim do século $X X$.

A intenção de diminuir as desigualdades sociais transformou-se numa bandeira importante no Brasil, que adotará então políticas redistributivas e de recuperações salariais, além de ampliação dos postos de trabalho no setor público, o qual na fase anterior passou por significativa contração. Assim, sobretudo a partir de 2005, houve aumentos significativos da renda das classes mais baixas devido, especialmente ao aumento real do salário mínimo e programas de transferência e aumento de renda, somados ao barateamento e expansão do crédito. A participação das classes B e C na estrutura social brasileira aumentou de 50\% a 60\% entre 2003 e 2009 (Jornal Brasil Econômico, 2010).

Essas mudanças culminaram na melhoria recente das condições de uma parcela da população brasileira. Contudo, não houve retração da emigração. A 
generalização da informação e do consumo, permitida pelos avanços nos meios de comunicação, por sua ampla difusão e pelo uso da primeira a serviço do segundo, também atinge aos mais pobres, fazendo-os desejar partilhar do "consumo moderno" (Santos, 2004). A emergência de uma parcela das camadas menos favorecidas a uma situação econômica melhor, permite a essa uma nova possibilidade: morar no exterior. Mesmo que para isso seja necessário o crédito, o qual, dado sua nova situação sócio-econômica, igualmente passa a estar disponível. Emerge, assim, uma "nova" classe média no Brasil que mudará o perfil dos emigrantes.

Esses pertencem predominantemente a classe média ou média inferior: "são migrantes com escolarização, em sua maioria de nível médio e dispõem de capital para utilização do meio de transporte rápido - avião" (Rossini, 2008: 344). Além disso, podem arcar com os gastos iniciais, o que inclui moradia, alimentação, transporte, até conseguirem um trabalho que possibilite sua permanência no novo país.

Em suma, a internacionalização da produção e a padronização e primazia do consumo são hoje motores da circulação e, mais especificamente, das migrações, inclusive das migrações de brasileiros. O período contemporâneo exige que a circulação do capital se dê em escala global, a circulação de pessoas, que tem nos fluxos de mão de obra sua forma principal, não foge a essa característica.

Daí a íntima ligação entre o papel desempenhado pelo país no panorama das migrações internacionais e o modo como ele se insere tanto economicamente, isto é, seu posicionamento na divisão internacional do trabalho, como politicamente no mundo. Dito de outra forma, e conforme se buscou evidenciar anteriormente ressaltando o caso brasileiro, as dinâmicas econômicas transnacionais e geopolíticas são fundamentais para 0 entendimento das migrações internacionais (Sassen, 2003).

Nessa perspectiva, atenta-se agora ao caso de Portugal. Ao ciclo contemporâneo das emigrações portuguesas, a partir de 1975 até os dias atuais, corresponde a emergência das imigrações como um fenômeno importante nas dinâmicas populacionais do país, o que decorre da conjunção de diferentes eventos. 
Esse é um período marcado pela crise do petróleo de 1973, pelo fim da ditadura em 1974 e pela adesão à Comunidade Econômica Européia em 1986. Os processos de democratização e descolonização pelos quais passa esse país na segunda metade do século XX redefinem-no tanto internamente como para além de suas fronteiras.

Essa redefinição encontrou no "voltar-se à Europa" uma necessidade, tanto política como econômica. Política porque significava o fortalecimento e garantia a estabilidade da recém-conquistada democracia; e, econômica porque Portugal carecia de recursos financeiros e organizacionais vindos da Europa para superar as perdas de suas ex-colônias.

De 1975 em diante, houve um movimento maciço de retorno de portugueses que viviam nas ex-colônias, em especial as africanas. Destacaram-se os retornados de Guiné, Moçambique e Angola, países que após a independência conheceram uma fase de grande turbulência política e social. O número total de retornados varia de 500000 a 800000 pessoas, porém são anos marcados por certa indefinição da nacionalidade de todos aqueles que voltavam a Portugal, já que as novas normatizações quanto à nacionalidade ainda eram incipientes (Rocha-Trindade, 2002).

A entrada de pessoas continuou crescendo na década de 1980. Porém, as distinções eram mais claras: na maior parte dos casos não se tratava mais de cidadãos portugueses retornados, mas sim de estrangeiros cidadãos de suas ex-colônias, com destaque para os cabo-verdianos, os quais vivem uma verdadeira diáspora.

Nos anos 1990 a imigração consolida-se e cresce em Portugal. As excolônias continuaram proeminentes no total dos estrangeiros residentes no país, principalmente os cabo-verdianos e os brasileiros. Na segunda metade dessa década, verifica-se também a diversificação dos fluxos, são novas áreas emissoras o leste-europeu e a Ásia (SEF, 2008, 2009).

Portugal apresenta hoje saldo migratório positivo, com estrangeiros totalizando 454191 pessoas $^{5}$, ou seja, pouco mais de $4 \%$ da população total residente no país. A seguir, pode-se verificar a evolução dessa parcela residente a partir da década de 1960.

${ }^{5}$ Dados provisórios publicados pelo SEF para o ano de 2009. Disponível em http://sefstat.sef.pt/evolucao.aspx, acesso realizado em 14 de julho de 2010. 


\section{Gráfico 1: Evolução da população estrangeira residente em Portugal no período de $1960-2008^{6}$}

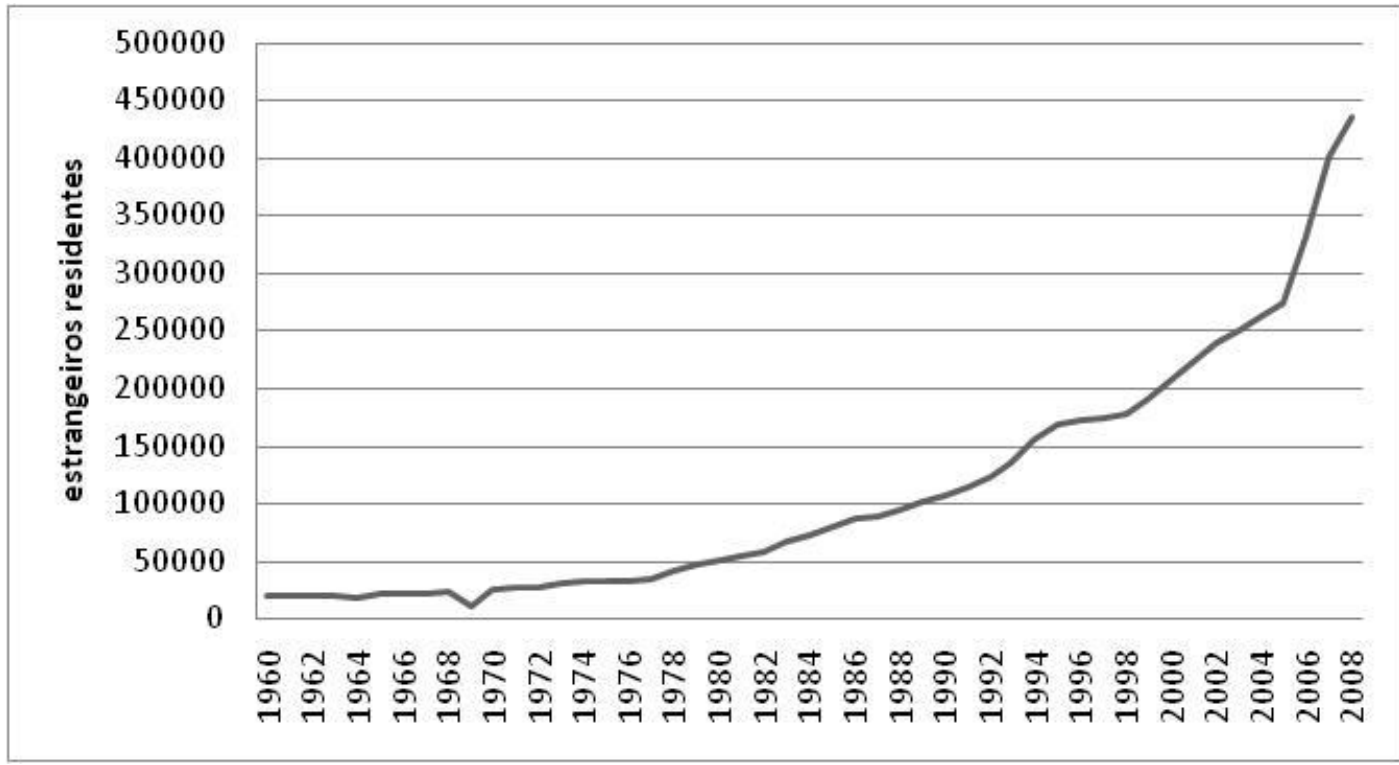

Fonte: SEF. Relatório de imigração, fronteiras e asilo, 2008. Portugal: Departamento de Planejamento e Formação, 2009. LAGES, Mário F. (et alli). Os imigrantes e a população portuguesa. Imagens recíprocas: Análise de duas sondagens. Lisboa: Observatório da Imigração/ACIME, 2006. Organização: Aline Lima Santos.

O gráfico 1 (Evolução da população estrangeira residente em Portugal no período de 1960 - 2008) evidencia um crescimento da imigração a partir da década de 1970, cujas motivações encontram-se nas circunstancias supra mencionadas. Mas é na década de 1980 que o ritmo desse crescimento se acelerará constantemente até o ano de 2000, a partir do qual há intensificação da imigração até 2004. Em 2005 verifica-se uma queda da imigração, que a partir de 2006 volta a apresentar um crescimento positivo, contudo, em ritmo mais modesto que o aproxima daqueles verificados na década de 1990.

A configuração dessa evolução é intrínseca a alguns fatores conjunturais. $\mathrm{O}$ crescimento do investimento europeu em Portugal nos anos 1980 e 1990 e o dinamismo econômico gerado daí certamente foram fundamentais para manutenção do crescimento em um ritmo constante.

O aumento verificado no início da década de 2000 provavelmente está relacionado a Exposição Mundial de 1998, sediada na cidade de Lisboa e a entrada em circulação do euro em 2002. Para sediar a Expo 2008, Portugal investiu pesadamente na porção oriental da cidade, que se encontrava bastante degradada. A construção da Ponte Vasco da Gama, a expansão da

\footnotetext{
${ }^{6}$ Os dados referem-se aos estoques da população estrangeira residente em Portugal nos anos considerados.
} 
linha do metro, o surgimento de edifícios modernos, dentre outras obras, e o evento em si colaboraram para atrair imigrantes nesse período. Passada essa fase:

\begin{abstract}
"os valores negativos registados em 2005 se reportam exclusivamente ao universo das autorizações de permanência, sendo certo que esta população sempre revelou características mais volúveis quanto à sua permanência em Portugal do que os beneficiários dos demais títulos, nomeadamente autorizações de residência, cujo quantitativo registou um aumento constante ao longo do tempo. Na verdade, os beneficiários de autorizações de permanência (equiparadas a um visto de trabalho) constituíam uma população mais flutuante, com vínculos menos consolidados no país de acolhimento, revelando até, por vezes, características de imigração temporária, cuja motivação é a permanência no país de destino por um lapso temporal limitado, retornando ao país de origem, após o aforro de algum capital" (SEF, 2008).
\end{abstract}

Contudo, o problema dos dados se impõe. É necessário destacar que esses números não incluem os migrantes irregulares, os quais, no entanto, são significativos. Conforme o excerto acima, as autorizações de permanência referem-se a imigrações em mais curto prazo, diferentemente das autorizações de residência. Podem existir casos em que, ao invés do retorno ao seu país, o imigrante com autorização de permanência tenha permanecido em Portugal, mas agora de modo irregular, já que o seu documento passou a apresentar a validade expirada, portanto, sem constar nas estatísticas oficiais.

Além disso, convém advertir sobre os limites das metodologias de obtenção desses dados. O próprio Serviço de Estrangeiros e Fronteira (SEF), em colaboração com o Instituto Nacional de Estatística (INE) português, dedicou-se à criação do Sistema de Informação do SEF nos últimos anos, o que permitiu a informatização do processo de recolhimento dos dados, antes realizados manualmente, bem como atualizações automáticas. A mudança culminou na quebra de série das estatísticas sobre a população imigrante residente em Portugal, tornando necessário reconsiderar os dados publicados antes de 2008. Infere-se, desse conjunto de advertências, que o número de imigrantes em Portugal é provavelmente superior ao que as estatísticas mostram. Porém, de qualquer maneira, elas são importantes porque nos dão a dimensão aproximada do fenômeno no país.

O gráfico 2 (Nacionalidades mais representativas no total da população estrangeira residente em Portugal, situação em 2008) mostra que Brasil, Ucrânia, Cabo Verde, Romênia, Angola, Guiné-Bissau e Moldávia, em ordem 
decrescente, são os países de origem de pouco mais de $70 \%$ dos imigrantes com permanência regular no território português (SEF, 2009). Nota-se que grande parte dos imigrantes (48\%) provém de países de língua portuguesa.

\section{Gráfico 2: Nacionalidades mais representativas no total da população estrangeira residente em Portugal, situação em 2008}

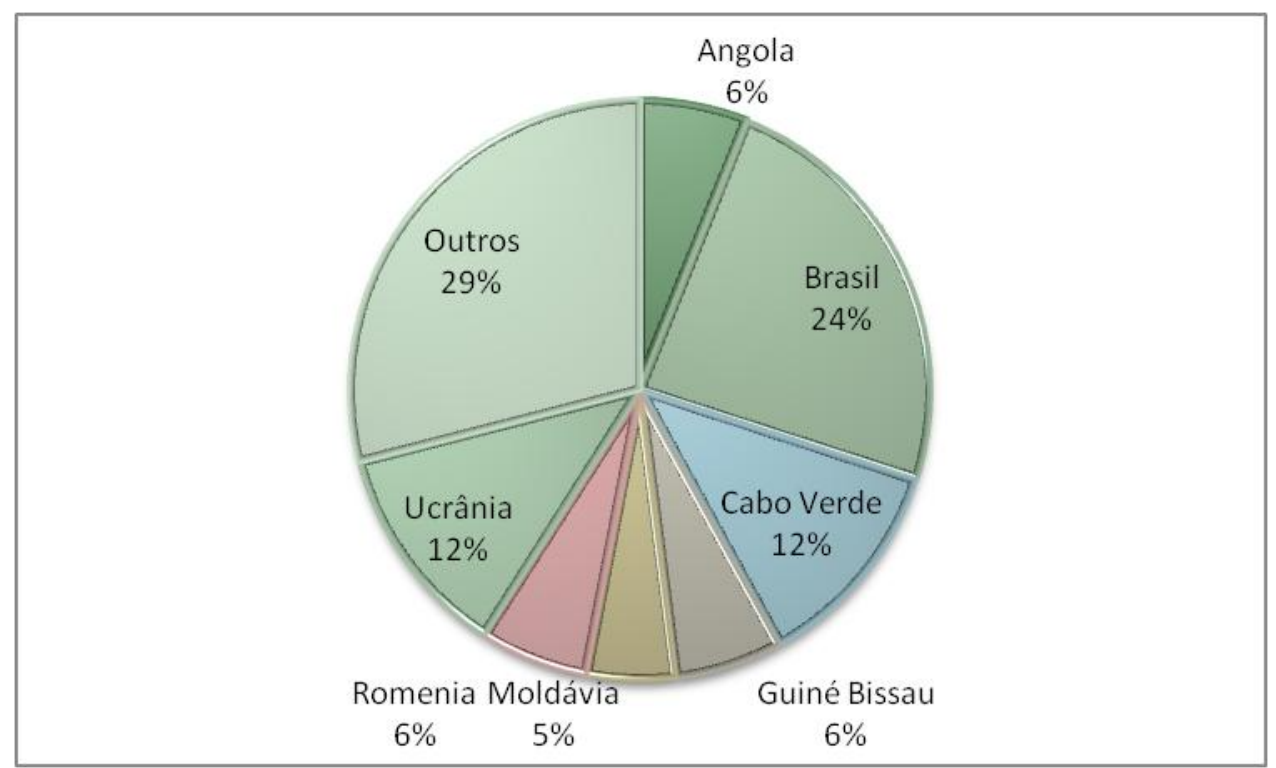

Fonte: SEF. Relatório de imigração, fronteiras e asilo, 2008. Portugal: Departamento de Planejamento e Formação, 2009.

Organização: Aline Lima Santos.

Os dados revelam que a população estrangeira residente em Portugal concentra-se nos distritos litorâneos, como se pode observar na figura 4 (Dispersão de imigrantes, por distritos, no território português, situação em 2008), principalmente em Lisboa, Faro e Setúbal, os quais juntos correspondem a $68 \%$ do universo considerado. Porto, Santarém, Leiria e Aveiro em conjunto seguem o ranking, somando pouco mais de $18 \%$ dessa população que é um tanto escassa nos distritos interioranos. Essa distribuição de estrangeiros em Portugal espelha a dos portugueses, que também ocupam majoritariamente a área litorânea. Para essa concentração da população residente no país, colabora o maior dinamismo econômico verificado na área (SEF, 2009). 
Figura 4: Dispersão de imigrantes, por distritos, no território português, situação em 2008

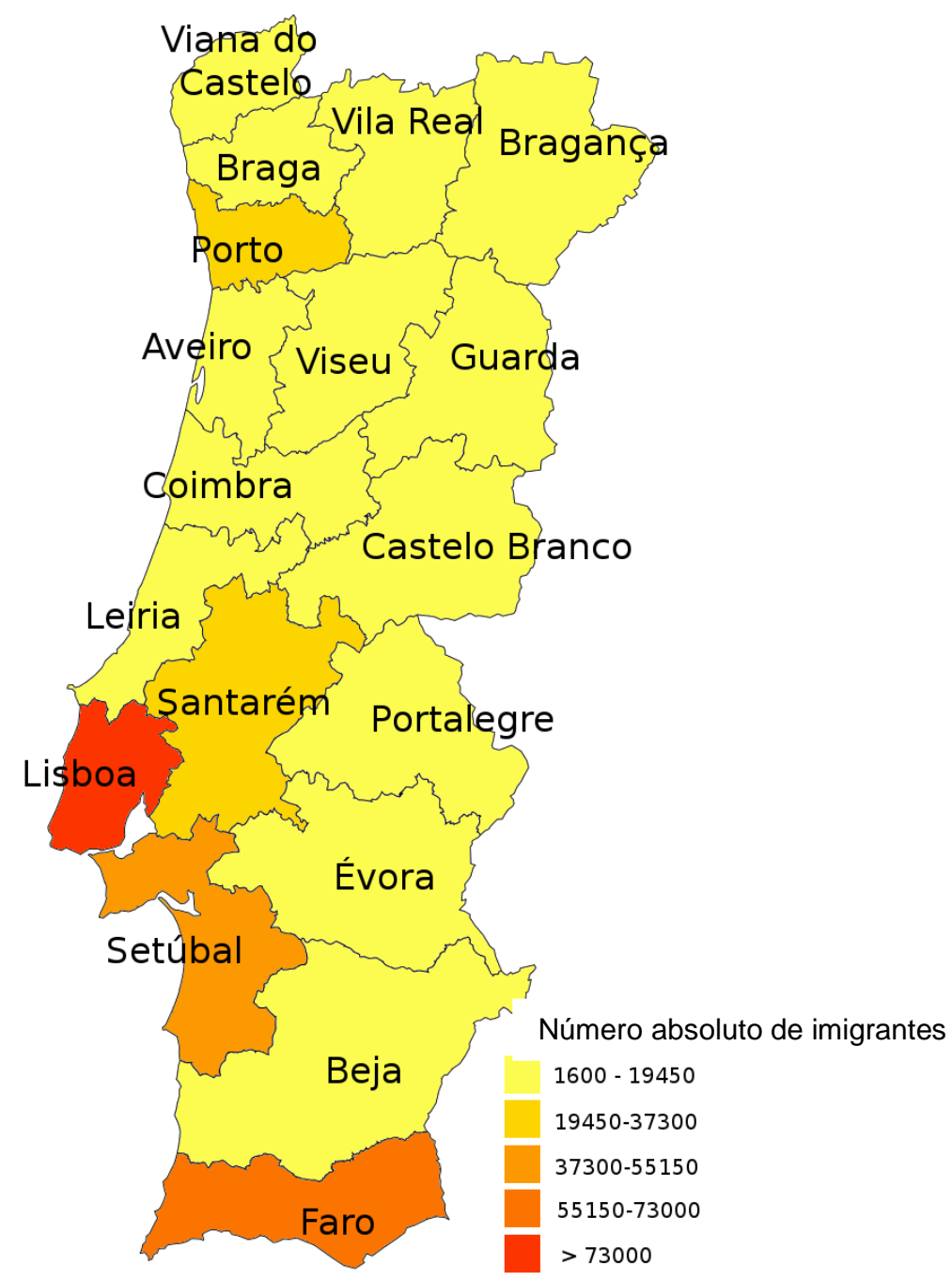

Fonte: SEF. Relatório de imigração, fronteiras e asilo, 2008. Portugal: Departamento de Planejamento e Formação, 2009.

Organização: Aline Lima Santos.

Elaboração: Germano de Castro Granda Neto.

Os imigrantes em Portugal constituem um grupo relativamente jovem. Predominam pessoas entre 20 e 39 anos, as quais representam $48,5 \%$ dessa parcela da população residente. Outro grupo etário se destaca: o de 40 a 64 anos, que corresponde a pouco mais de $30 \%$. As faixas de pessoas menores de 20 anos e maiores de 65 correspondem a pouco mais de 20\%. Daí infere-se a importância da participação dos estrangeiros na população economicamente ativa em Portugal. 


\section{Gráfico 3: Imigrantes em Portugal por grupo etário, situação em 2008}

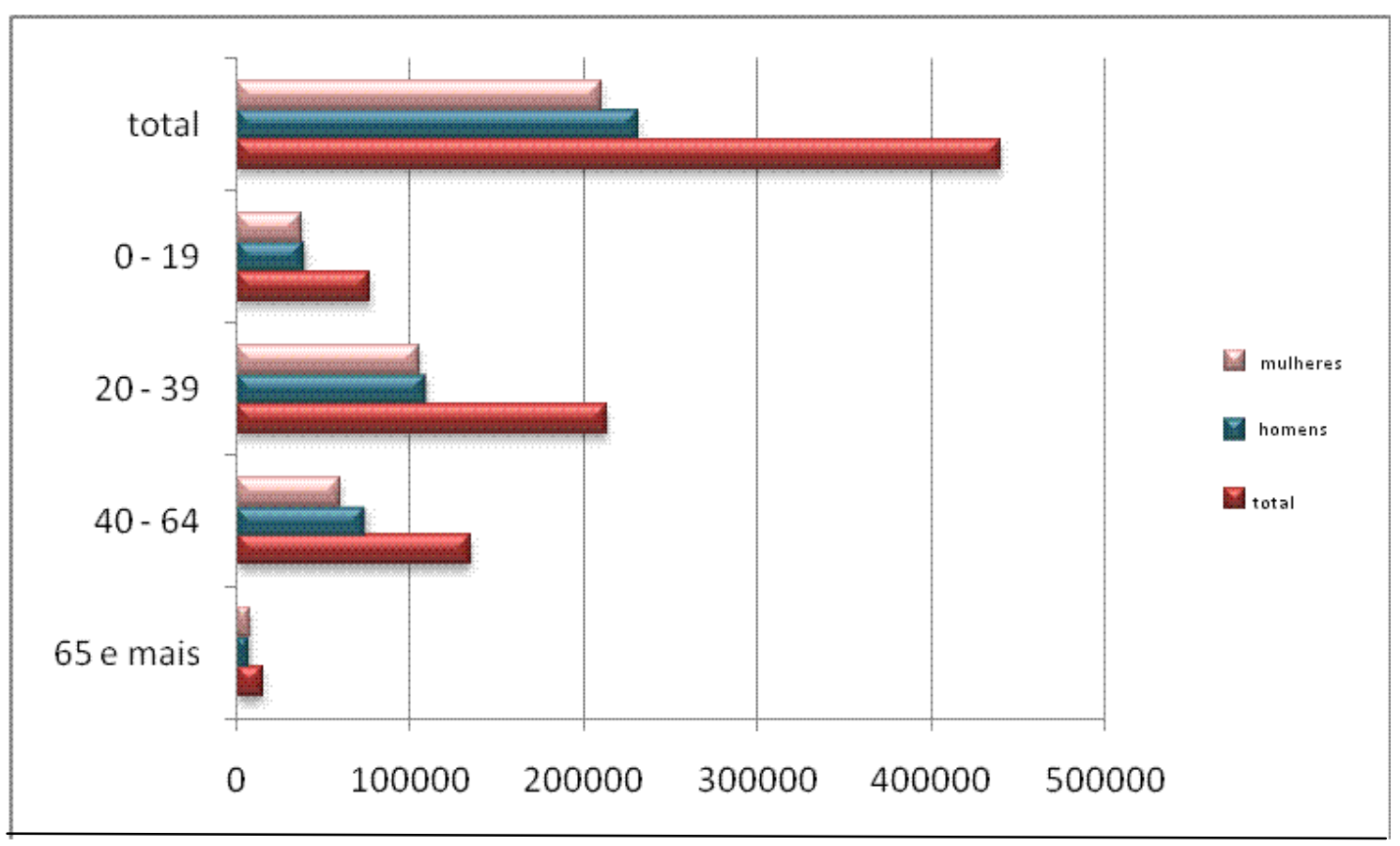

Fonte: SEF. Relatório de imigração, fronteiras e asilo, 2008. Portugal: Departamento de Planejamento e Formação, 2009.

Organização: Aline Lima Santos.

Dentre os estrangeiros predominam os homens, como se pode observar no gráfico 3 (Imigrantes em Portugal por grupo etário, situação em 2008), os quais representam $52 \%$ do total, contudo verifica-se uma diferenciação dessa característica de acordo com a nacionalidade analisada. Nos grupos vindos dos países africanos de língua portuguesa, por exemplo, há leve predominância das mulheres, que também são majoritárias dentre os grupos originários do continente americano.

A maior taxa de masculinidade é verificada no grupo etário de 40 a 64 anos. Como geralmente a decisão pela migração se dá em fases mais jovens da vida, talvez esse grupo seja formado por estrangeiros que estão em Portugal há mais tempo. Tal fato pode sugerir que os fluxos mais recentes são formados por mais mulheres do que os fluxos mais antigos, o que se explicaria pelo papel crescente da reunificação familiar na composição dos mesmos.

Portugal, dessa maneira, firma-se nas últimas três décadas como país de imigração, em consonância com a região da qual faz parte. A figura 3 (Principais Movimentos Migratórios, situação em 2005) demonstra o papel da 
Europa, especialmente a União Européia, e dos Estados Unidos nas migrações internacionais contemporâneas: são destinos de milhares de pessoas que deixaram seus países. Os fluxos migratórios a eles dirigidas são das mais diversas proveniências, as quais coincidem com suas respectivas áreas de influência. Os principais países receptores hoje são os mesmos que comandam o processo de globalização, concentrando fluxos de comércio de bens e informações e também de pessoas, o que se pode observar na comparação entre a figura 3 e a figura abaixo.

\section{Figura 5: Os três grandes pólos do comércio global}

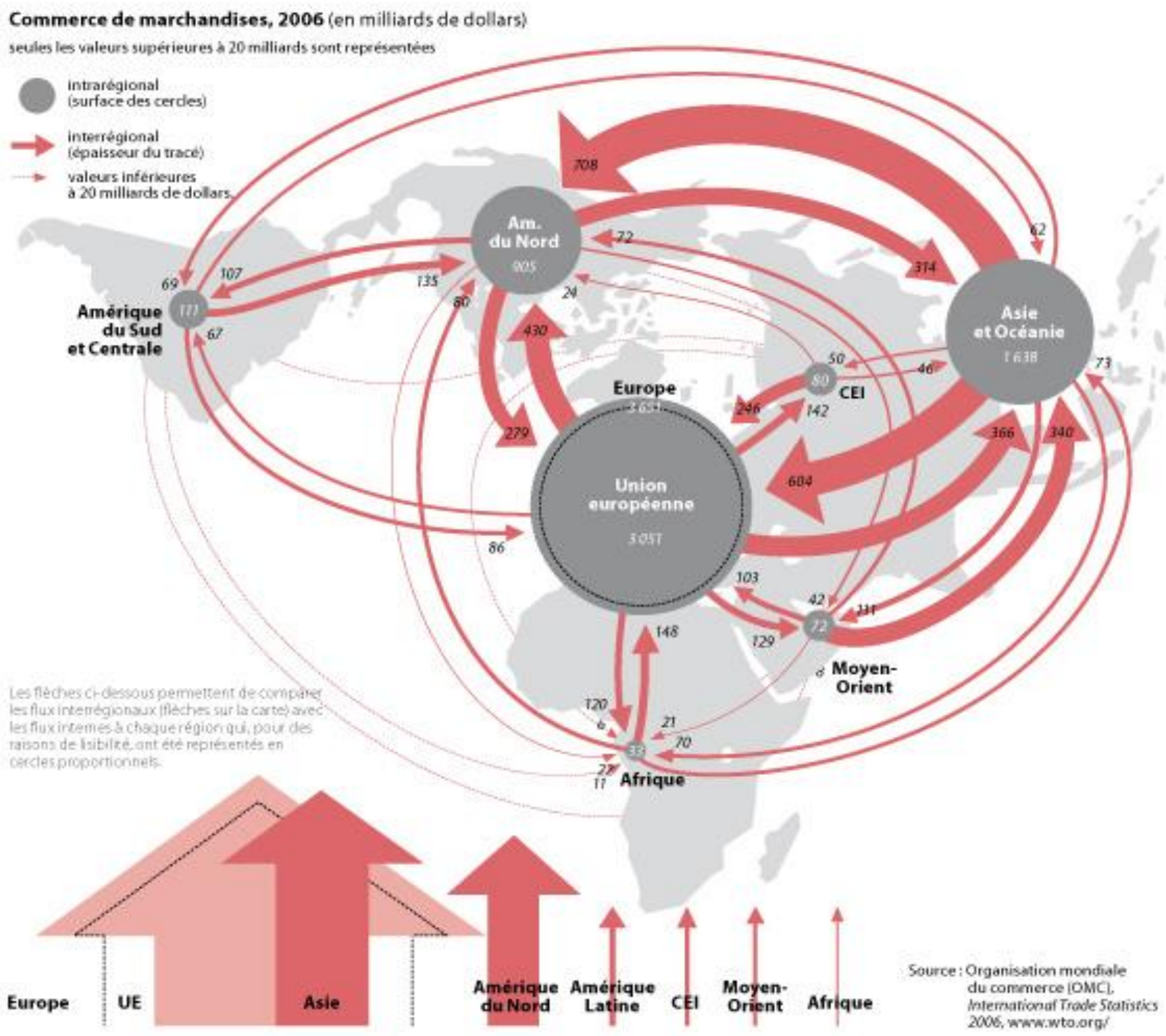

Fonte: Atelier de cartographie de Sciences Po, 2010. Disponível em www.sciences-po.fr/cartographie (acesso em 06/05/2009) 
Em grande parte dos casos, os países de origem coincidem com aqueles pertencentes à periferia ou a semi-periferia do capitalismo mundial, cuja participação nos fluxos materiais e imateriais mundiais é reduzida, tal como é possível observar na figura anterior. Porém, estudos mostram que países muito ricos e muito pobres, apresentam taxas de emigração baixas, essas seriam mais elevadas em países de desenvolvimento médio (PNUD, 2009).

Assim, é insuficiente colocar a pobreza como principal causa da emigração. Muitos países pobres apresentam escassa emigração, em contrapartida, alguns países de origem de migrantes passam por um rápido crescimento econômico, caso da Coréia do Sul e de Taiwan, por exemplo, o que coloca em cheque também a estagnação econômica, e o conseqüente desemprego como principal elemento a pressionar a saída de pessoas (Sassen 2003).

A essas constatações somam-se as características demográficas: os países do centro do sistema são os que apresentam as menores taxas de crescimento populacional, o que decorre da diminuição das taxas de fecundidade e natalidade. Se, como mencionamos, a Europa já concentrou cerca de um quarto da população mundial, seu peso não chegava a metade disso em 2008, quando esse continente concentrava pouco mais de $11 \%$ das 6,7 bilhões de pessoas no mundo (United Nations, 2009).

Seguindo a tendência do continente, Portugal tem débil crescimento populacional. Seu crescimento vegetativo é perto de zero: no qüinqüênio de 2003 a 2008, a idade média com que as mulheres tinham o primeiro filho passou de 27,4 anos para 28,4. No mesmo período a taxa de natalidade diminuiu de $10,8 \%$, para $9,8 \%$, nascidos vivos por habitantes. Em 2008, a taxa de fecundidade era de 1,37 filhos por mulher.

Concomitante à decisão tardia pela maternidade por parte das mulheres e à diminuição dos nascimentos, a população portuguesa envelhece. A longevidade aumentou o que se evidencia no aumento do índice de envelhecimento: de 107, em 2003, para 115 idosos para cada 100 jovens, em 2008 (INE, 2009). Tem-se, desse modo, uma pirâmide etária com base mais estreita e topo mais largo, em 2008, comparativamente a 2003 , como se pode observar no gráfico a seguir: 


\section{Gráfico 4: Pirâmide etária de Portugal, situação em 2003 e 2008}

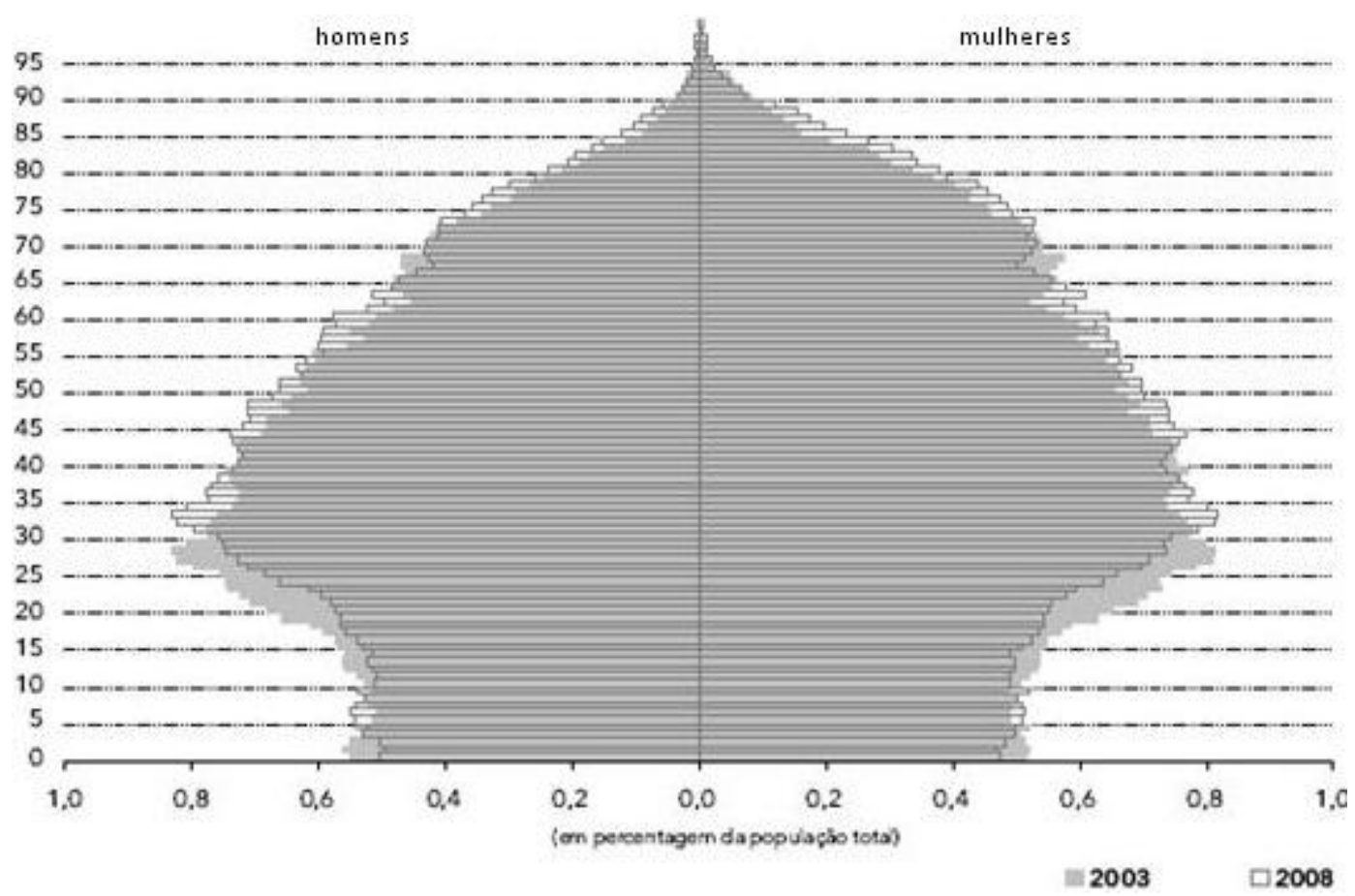

Fonte: INE. Estatísticas Demográficas 2008. Lisboa: INE, 2009.

O exemplo português permite inferir que convém à Europa de modo mais geral receber imigrantes. As migrações, então, deveriam ser desejadas, pois colaborariam na manutenção da população residente em níveis sustentáveis para bom desempenho econômico e social dos países. Mas a questão é algo mais complexa. Verifica-se nos mesmos a adoção de políticas migratórias bastante restritivas na contramão do que seria esperado.

Para muitos países receptores, como os que compõem hoje a União Européia e os Estados Unidos, a falta de controle das fronteiras quanto à entrada de pessoas é uma verdadeira ameaça, já que se correria neste período o risco de entrada de grandes levas de pessoas provenientes de países pobres. Esse raciocínio baseia-se no fato de que a América Latina, a África e a Ásia, conhecem uma aceleração do crescimento populacional, devido a queda brutal da mortalidade decorrente da inserção de melhorias médico-sanitárias após a Segunda Guerra Mundial. Tais fatos demográficos são amplamente conhecidos em seus pormenores e aqui não será dada ênfase maior. Eles só foram assinalados porque parecem evidenciar alguma relação entre densidade 
populacional e o peso de uma área entre aquelas das que mais emigram pessoas.

A partir deles comumente se deduz que quanto maior o crescimento populacional e a população relativa, maior o número de emigrantes. O aumento da população e a alta densidade populacional pressionariam os recursos disponíveis, tornando-os insuficientes para satisfação das necessidades de todas as pessoas, isso levaria à emigração. Todavia, há nessa abordagem um reducionismo da relação entre migração e disponibilidade de recursos à população, assim como é simplista as explicações clássicas sobre as causas das migrações pautadas na pobreza e na estagnação econômica (Sassen, 2003).

As políticas migratórias adotadas pelos países ricos buscam estabelecer os imigrantes desejados dos não desejados. Os critérios remetem-se, geralmente, às necessidades do mercado de trabalho interno, mas privilegiamse os imigrantes de elevados níveis sócio-econômicos.

Entretanto, não se pode ignorar que a existência de migrantes em situação irregular denuncia a ineficácia de tais políticas e a ineficiência dos Estados em colocá-las em prática. Mais uma vez, os processos econômicos de âmbito internacional que aprofundaram a globalização colaboram para a compreensão desse fato.

O crescimento da atuação das grandes empresas nos países pobres fez concentrarem-se aí os investimentos e as atividades industriais. As isenções fiscais, os baixos salários, dentre outros elementos, atraem essas empresas a se instalar aí visando diminuir custos com o intuito de aumentar os lucros. A conseqüência nos países ricos é a mesma identificada para os Estados Unidos por Sassen (2003):

"A medida que la producción industrial se há desplazado a otros destinos ultramarinos, la tradicional base manufacturera estadounidense se há erosionado y ha sido parcialmente reemplazada por un sector manufaturero degradado, caracterizado por uma oferta creciente de empleos productivos pobremente pagados, semicalificados o no calificados em absoluto. Al mismo tiempo, el rápido crecimiento del sector de servicios ha creado un vasto número de empleos de bajo salário (además del muy publicitário incremento em trabajos muy bien pagos em bancos de inversión o empresas consultoras)". 
Vê-se, portanto, emergir nos países ricos nichos no mercado de trabalho que oferecem oportunidades de engajamento para imigrantes tanto altamente qualificados como aqueles que exigem baixa formação. Ao mesmo tempo, isso ocorre com a flexibilização de contratos de trabalho, diminuição do poder dos sindicatos também relacionados ao modo como atuam as grandes empresas no mundo. A ação dessas colabora, nos países ricos, ao desmonte do Estado de Bem Estar Social.

Nas atuais condições, torna-se cada vez mais difícil aos países ricos a manutenção das conquistas sociais obtidas por esse Estado. Está-se diante do risco do surgimento de uma pobreza sem segurança, que caracteriza a realidade dos países pobres, cuja parcela dos trabalhadores buscam cotidianamente os ganhos que the possibilite continuar a viver (Santos, 2004). Os primeiros a serem atingidos são os grupos sociais mais vulneráveis, dentre eles, os imigrantes, em especial aqueles em situação irregular.

As políticas migratórias restritivas, portanto, somam a uma série de medidas cujos argumentos remetem a insustentabilidade do Estado do Bem Estar Social a toda a população residente. Politicamente, portanto, busca-se proteger a população nacional. Mas há uma incompatibilidade das posturas políticas restritivas diante do fenômeno migratório atual, muito mais complexo do que logram explicar as frequentes justificativas dadas.

Essas posturas se esquecem de considerar fatores históricos, sociais, econômicos, políticos e demais elementos que compõem a dinâmica do espaço geográfico. A heterogeneidade e desigualdade presente no espaço geográfico resultam nas migrações, mas vão além de dados meramente demográficos ou econômicos. Mais fértil seria enxergar "as migrações como uma expressão espacial dos mecanismos de modernização" (Santos, 2004: p.302) que hoje caracterizam a globalização, considerando o espaço geográfico como um sistema (Santos, 2002, 2004).

É nessa perspectiva que aqui se busca compreender a emigração no Brasil e a imigração em Portugal e o fluxo do primeiro para o segundo. Nos itens subseqüentes, interessa compreender a posição de Portugal dentre os demais fluxos que saem do Brasil. 


\subsubsection{Para onde vão os brasileiros?}

Segundo estimativas mais recentes, referentes ao ano de 2008, do Ministério das Relações Exteriores (MRE), os brasileiros que vivem fora do Brasil somam 3.040 .993 pessoas, o que corresponde a pouco mais de $1,5 \%$ do total da população brasileira. Observando dados da contagem da população realizada pelo IBGE referente ao ano de 2007 , podemos perceber que a quantidade de brasileiros no exterior supera o número de pessoas de pelo menos sete unidades da federação (Acre, Amapá, Distrito Federal, Mato Grosso do Sul, Rondônia, Roraima, Sergipe e Tocantins).

Ressalva-se: a imigração constitui-se também em um fenômeno importante no Brasil contemporâneo, mesmo que em menor grau do que no passado, como por exemplo, o caso dos coreanos e dos bolivianos, bem como as migrações internas. Esses temas não se encontram esgotados como objeto de pesquisas, todavia não estão nas preocupações dessa análise.

As estimativas supracitadas, no entanto, muito provavelmente estão aquém da realidade. Os estudos focados nos fluxos que compõem o espaço geográfico sempre se deparam com os limites das metodologias de se quantificar os movimentos, o caso dos fluxos de pessoas não foge a isso. Não há mais controle sistemático de entradas ou saídas a partir de 1960 nos portos e aeroportos do país, por exemplo. A grande maioria das pessoas que emigram o fazem como turistas, poucos solicitam autorização de permanência, o mesmo serve para as entradas. Daí pode-se inferir que o número de entradas e de saídas de migrantes é superior ao que se tem disponível.

Dito o volume total, interessa agora explicitar a distribuição desses migrantes. O gráfico 5 (Distribuição de brasileiros que vivem no exterior, situação em 2009) sintetiza os dados sobre a magnitude da presença brasileira como parcela da população total residente nas diferentes regiões do mundo. 


\section{Gráfico 5: Distribuição de brasileiros que vivem no exterior, situação em}

2009

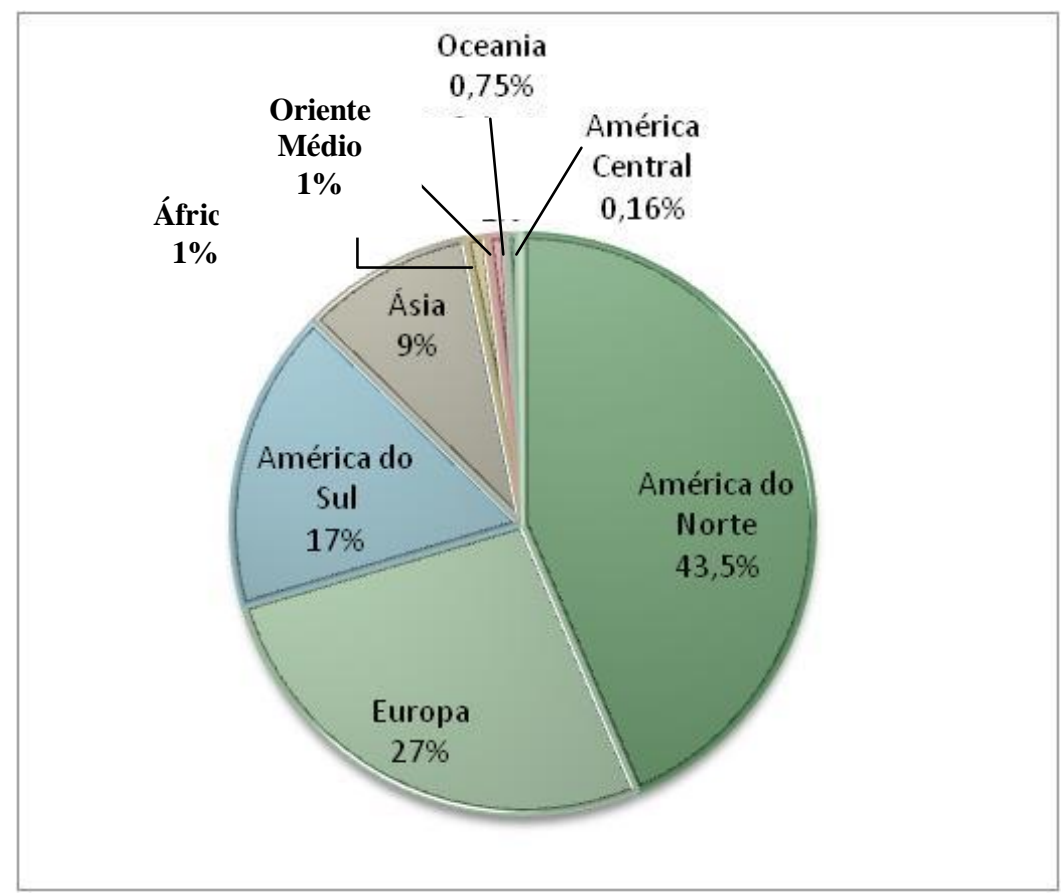

Fonte: Ministério das Relações Exteriores. Brasileiros no Mundo: Estimativas. Segunda Edição, Setembro de 2009. Organização: Aline Lima Santos

Ainda que os dados subestimem seu real volume, os atuais fluxos migratórios que partem do Brasil possuem como principais destinos, em termos numéricos, os Estados Unidos, seguidos pela Europa (principalmente Reino Unido, Portugal, Espanha, Alemanha, Itália), o Japão e países fronteiriços do Brasil, especialmente o Paraguai, Argentina, Venezuela e Uruguai, em ordem decrescente. Essa distribuição dos brasileiros no mundo demonstra, como se pode observar no gráfico anterior, que há um importante fluxo direcionado principalmente aos países do hemisfério norte, isto é, sentido sul-norte, e outro direcionado aos vizinhos, isto é, predominantemente sentido oeste-leste.

O gráfico 6 (Percentual de imigrantes brasileiros em relação aos dez principais países receptores, situação em 2009) mostra a participação dos 10 países que concentram a maior parte do número de brasileiros que vivem no exterior. Juntos esses países reúnem aproximadamente $85 \%$ do total das pessoas que emigraram. Ambos os gráficos demonstram que os fluxos de brasileiros para o exterior são predominantemente direcionados aos países ricos da América do Norte e da Europa, os quais correspondem ao destino de cerca de $70 \%$ desses migrantes. 


\section{Gráfico 6: Percentual de imigrantes brasileiros em relação aos dez principais países receptores, situação em 2009}

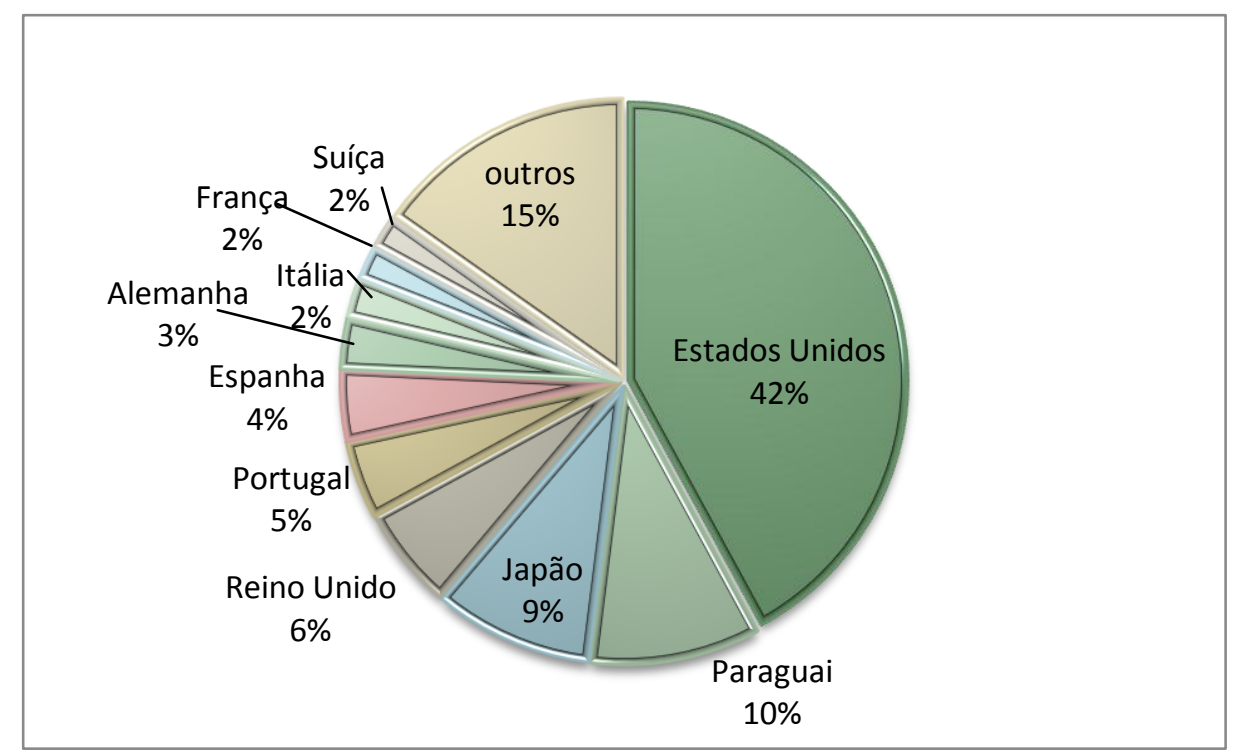

Fonte: Ministério das Relações Exteriores. Brasileiros no Mundo: Estimativas. Segunda Edição, Setembro de 2009. Organização: Aline Lima Santos.

Nos Estados Unidos, segundo dados do Ministério das Relações Exteriores (MRE) encontram-se $42 \%$ dos brasileiros que vivem no exterior. Em termos absolutos são 1.280 .000 pessoas, das quais mais de $60 \%$ encontramse situação irregular. A distribuição dessa população, segundo as jurisdições dos Consulados Gerais do Brasil, se dá da seguinte maneira: 27\% em Nova lorque, 27\% em Boston, 23,5\% em Miami, 7\% em Atlanta, 4\% em Houston, 4\% em Los Angeles, 2\% em Washington, 3,5\% em São Francisco, 2\% em Chicago. Percebe-se, portanto, que na costa leste dos Estados Unidos encontram-se $85 \%$ do número de brasileiros presentes no país, sendo mais de $50 \%$ concentrados no norte (Nova lorque e Boston).

Devido a sua relevância no conjunto dos principais destinos de brasileiros, é importante uma breve contextualização desse fluxo, o que pode ser feito a partir de um caso específico: a cidade de Governador Valadares (MG). No final da década de 1940, essa cidade experimentou uma fase de apogeu do extrativismo da mica, o que despertou interesses dos Estados Unidos, trazendo de lá inúmeros americanos. Esse minério era utilizado na fabricação de rádios durante a Segunda Guerra (Sales, 1995). Pouco antes, 
no início da década, é instalado na cidade um serviço de saúde que visava combater a malária e era produto de um convênio Brasil - EUA (Assis, 1999).

A convivência com esses estrangeiros oriundos dos Estados Unidos em Governador Valadares é associada à modernização e ao progresso da cidade pelas pessoas que aí vivem. Essa convivência gerou a ilusão dos ganhos em dólar e instigou os fluxos que daí partiram nos anos 1960, mas que se tornaram mais expressivos dos anos 1980 em diante. Em meados da década de 1990, esse destino absorvia cerca de $20 \%$ da população da cidade.

Na Europa concentram-se 816.257 , isto é, $27 \%$ dos brasileiros residindo fora do país. O destino mais escolhido é o Reino Unido, com 180000 pessoas. Nota-se a presença de mais de 250000 brasileiros vivendo na Península Ibérica. A comunidade brasileira em Portugal (137 600 pessoas) representa cerca de $4,5 \%$ em relação ao total mundial. Destaca-se também a presença de importante comunidade brasileira na Alemanha (89 000 pessoas) e na Itália (70 000 pessoas), esta última formada majoritariamente por mulheres (quase 2/3 do total) casadas com italianos (MRE, 2009).

$\mathrm{Na}$ Espanha, os brasileiros somam mais de 125000 pessoas. Nos últimos anos o crescimento desta comunidade estrangeira no país foi expressivo e recentemente ganhou considerável espaço na mídia devido à rigorosa postura adotada pela Espanha no que se refere aos imigrantes brasileiros, chegando a provocar incidente diplomático.

No caso do Japão, a estimativa é de que aí existam 280000 brasileiros, isto é, pouco mais de $9 \%$ do total. Trata-se, sobretudo, de uma migração de japoneses descendentes, nisseis e sanseis, ou integrados pelo casamento. Relacionam-se, portanto, à questões históricas e culturais, assim como alguns dos fluxos direcionados para a Europa. Os brasileiros constituem no Japão, segundo Rossini (2007), "a terceira nacionalidade em número de estrangeiros, só superada pelos coreanos e chineses" (p.1).

Sobre o fluxo direcionado aos países fronteiriços salienta-se a característica de que predominam aqueles que na origem estiveram direcionados ao campo, diferentemente dos orientados aos países ricos, onde predominam concentrações nas áreas urbanas. O Paraguai merece menção mais atenta, pois representa $10 \%$ em relação ao total, isto é, a segunda maior comunidade brasileira no exterior, enquanto Argentina, Bolívia, Suriname, 
Guiana Francesa, Uruguai e Venezuela somados correspondem a pouco mais de $6 \%$.

Nesse país a questão agrária associada à imigração brasileira é bastante relevante (Sprandel, 2006). Em sua origem, na década de 1970, está a construção de Itaipu, o processo de concentração de terras no sul do Brasil, especialmente no Paraná e, mais recentemente, no Centro-Oeste, em virtude da expansão da soja, e as facilidades oferecidas pelo Estado paraguaio, durante o governo Stroessner, para aquisição de terras por estrangeiros, visando atrair mão-de-obra para transformar o país em importante produtor de soja. Muitos conflitos ocorreram envolvendo a população local e a comunidade brasileira, a qual ficou conhecida como "brasiguaios".

No panorama esboçado acima, interessa aqui os brasileiros que tem como destino Portugal, quinto país que mais acolhe brasileiros no mundo e segundo principal receptor de brasileiros que vão para a Europa (Gráfico 6: Percentual de imigrantes brasileiros em relação aos dez principais países receptores, situação em 2009). A importância desse fluxo ainda é mais saliente se se considera o peso da comunidade brasileira em relação à população total residente no país, relação essa evidenciada na tabela a seguir:

Tabela 1: Participação dos brasileiros no total de habitantes dos dez principais países receptores - situação em 2009

\begin{tabular}{|c|c|c|c|}
\hline País & $\begin{array}{c}\text { Brasileiros } \\
\text { (número absoluto) }\end{array}$ & Total de habitantes do país & $\begin{array}{c}\text { Participação brasileira no } \\
\text { total dos habitantes do } \\
\text { país }\end{array}$ \\
\hline Paraguai & 300.000 & 6.348 .917 & $4,70 \%$ \\
\hline Portugal & 137.600 & 10.707 .130 & $1,30 \%$ \\
\hline Suíça & 57.500 & 7.567 .661 & $0,75 \%$ \\
\hline Estados Unidos & 1.280 .000 & 314.658 .780 & $0,40 \%$ \\
\hline Reino Unido & 180.000 & 61.565 .422 & $0,29 \%$ \\
\hline Espanha & 125.000 & 44.903 .659 & $0,27 \%$ \\
\hline Japão & 280.000 & 127.156 .225 & $0,22 \%$ \\
\hline Itália & 70.000 & 59.870 .123 & $0,11 \%$ \\
\hline Alemanha & 89.000 & 82.166 .671 & $0,10 \%$ \\
\hline França & 60.000 & 62.342 .668 & $0,09 \%$ \\
\hline
\end{tabular}

Fonte: Ministério das Relações Exteriores. Brasileiros no Mundo: Estimativas. Segunda Edição, Setembro de 2009. United Nations. Indicator on Population. In United Nations Statistics Division. Demographic and Social Statistics. Statistical Products and Databases. Social Indicators, 2009.

Organização: Aline Lima Santos 
Como se pode verificar, aproximadamente $1,3 \%$ da população residente em Portugal é composta de imigrantes brasileiros. É necessário, para os objetivos desse trabalho, revelar as especificidades desse fluxo.

\subsubsection{Portugal - promissor e incerto: uma escolha de migrantes brasileiros}

Embora se tenha elegido a década de 1980 como chave para análise da imigração brasileira contemporânea, outras periodizações são possíveis, dependendo dos objetivos, visto que o fluxo de pessoas no mundo lusófono é permanente na história, mesmo apresentando momentos de sístoles e diástoles. Não se trata, pois, de estabelecer a década de 1980 como o início de uma imigração brasileira em Portugal.

Bógus (2007) afirma, por exemplo, que na década de 1960 a comunidade brasileira era a mais numerosa dentre os estrangeiros residentes em Portugal, mas de 1960 a 1980 o aumento da presença africana diminui a importância relativa dessa comunidade, que conhece, então, um período de letargia. Viana (1995) destaca que na década de 1970 o Brasil contribuiu para uma imigração predominantemente vinculada a motivações políticas, enfatiza, porém: "era outro movimento".

Portugal criou condições para atração de imigrantes em meados da década de 1970. A reestruturação pela qual passava o país permitiu o retorno dos que o haviam deixado por motivos políticos, mas também incentivava a volta dos que, por outros pretextos viviam no Brasil. Assim, é uma imigração que se caracterizava pelo retorno de portugueses, muitos aposentados, acompanhados de esposas ou esposos brasileiros e filhos. Esse fluxo para Portugal vai intensificando-se nas décadas seguintes, muito embora seus conteúdos vão se transformando.

Nesse primeiro momento, os imigrantes brasileiros direcionam-se a áreas que tradicionalmente foram emissoras de portugueses para o Brasil (figura 2: Emigração portuguesa por distrito de naturalidade). É, portanto, um refluxo que irá se acirrar especialmente na segunda metade da década de 1980, quando a conjuntura econômica e política no Brasil passa a justificar a emigração. Esse novo contexto em que se dá a ida de brasileiros para Portugal justifica a periodização que aqui se toma. 
Há em Portugal um rápido crescimento da comunidade brasileira, a qual, na década de 1980, sai da insignificância e torna-se, na década seguinte, a segunda maior dentre as demais comunidades estrangeiras aí presentes, atingindo no presente a primeira posição. A evolução da presença de imigrantes brasileiros em Portugal paralelamente à evolução do total de estrangeiros pode ser observada no gráfico a seguir:

\section{Gráfico 7: Evolução do número de brasileiros no total de estrangeiros com autorização de residência (A. R.) em Portugal no período de 1960 a 2008}

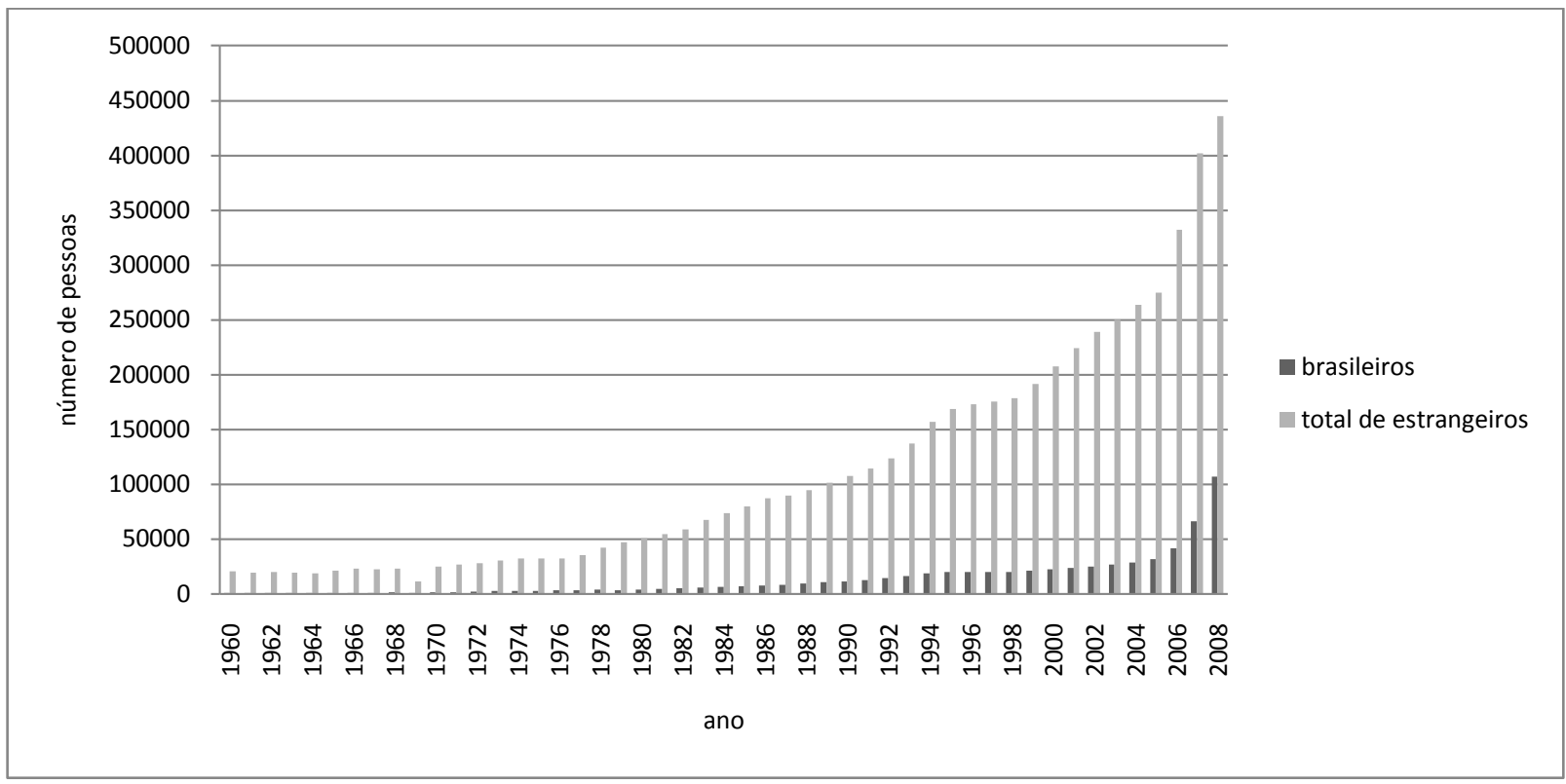

Fonte: SEF e INE.

Organização: Aline Lima Santos

O gráfico 7 (Evolução do número de brasileiros no total de estrangeiros com autorização de residência (A. R.) em Portugal no período de 1960 a 2008) demonstra que, de certo modo, a evolução da comunidade brasileira em Portugal acompanhou o incremento do total de estrangeiros aí presente, colaborando para o crescimento da mesma. Mostra também que a partir dos anos 1980 a evolução permite um recorte privilegiado para compreender 0 movimento atual, pois sintetiza as migrações motivadas pela política e a fase cujas justificativas se dão, sobretudo pelas causas econômicas. 
Considerando apenas os imigrantes regulares, com autorização de residência, Portugal chega a 1980 com 3.608 brasileiros em seu território. O gráfico 8 (Evolução do número de brasileiros com autorização de residência (A. R.) em Portugal no período de 1980 a 2008) permite um visualização mais detalhada da evolução dessa comunidade a partir de 1980.

Gráfico 8: Evolução do número de brasileiros com autorização de residência (A. R.) em Portugal no período de 1980 a 2008

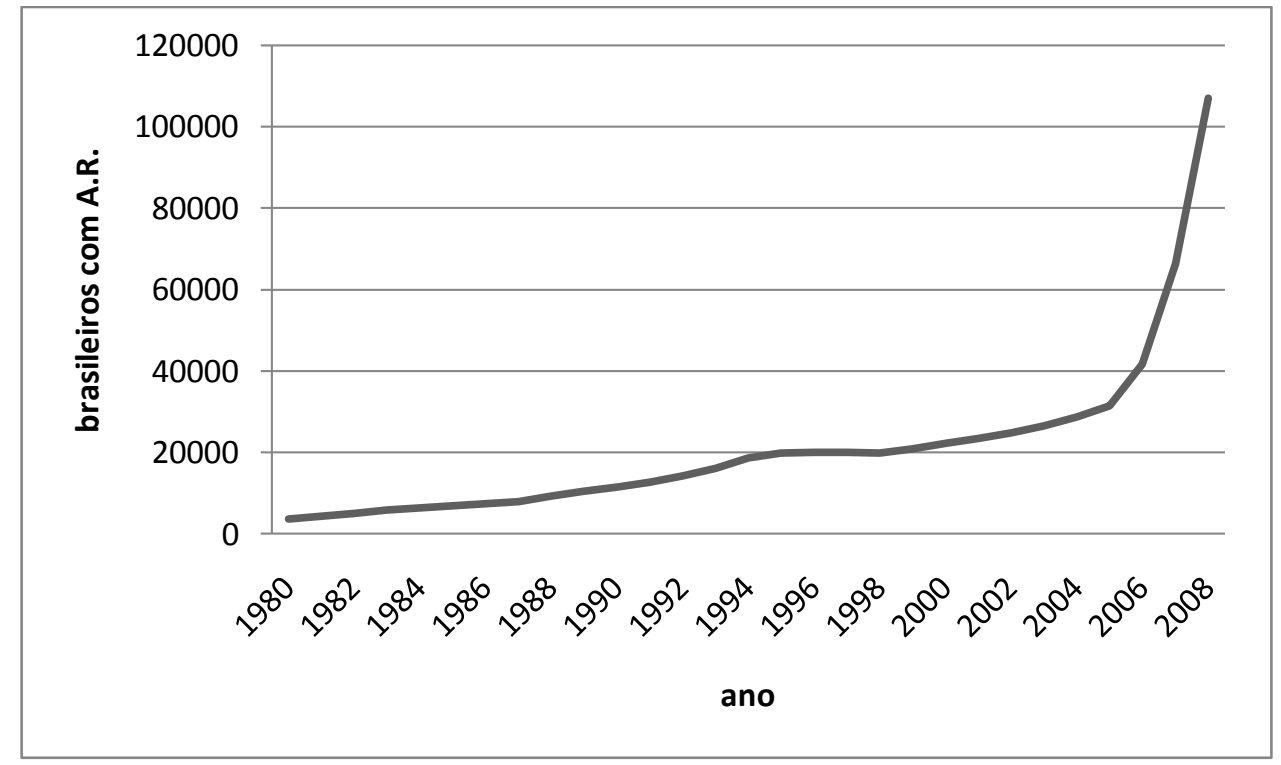

Fonte: SEF e INE

Organização: Aline Lima Santos

Era, como já foi dito, uma população que acompanhava os portugueses retornados, mas era também trabalhadores levados pelas relativamente poucas empresas brasileiras atuantes em território português e mesmo os trabalhadores ligados aos serviços diplomáticos brasileiros (Viana, 1995). A participação relativa desses imigrantes no total de estrangeiros residentes em Portugal nas mesmas condições, isto é, com A.R., era de pouco mais de 6\%, o que era irrisório comparativamente a participação de cabo-verdianos, por exemplo.

Mas a partir daí, a comunidade brasileira apresentou crescimento em um ritmo com poucas variações, o que faria crescer, do mesmo modo, sua importância relativa no total de estrangeiros residentes, como é possível notar no gráfico 9 (Evolução do percentual de brasileiros com autorização de residência (A. R.) em Portugal no período de 1960 a 2008), colocando-a entre 
as comunidades mais numerosas. Isso permaneceria até 1994, como pode ser observado no gráfico 8 (Evolução do número de brasileiros com autorização de residência (A. R.) em Portugal no período de 1980 a 2008) e no gráfico 9.

Gráfico 9: Evolução do percentual de brasileiros com autorização de residência (A. R.) em Portugal no período de 1960 a 2008

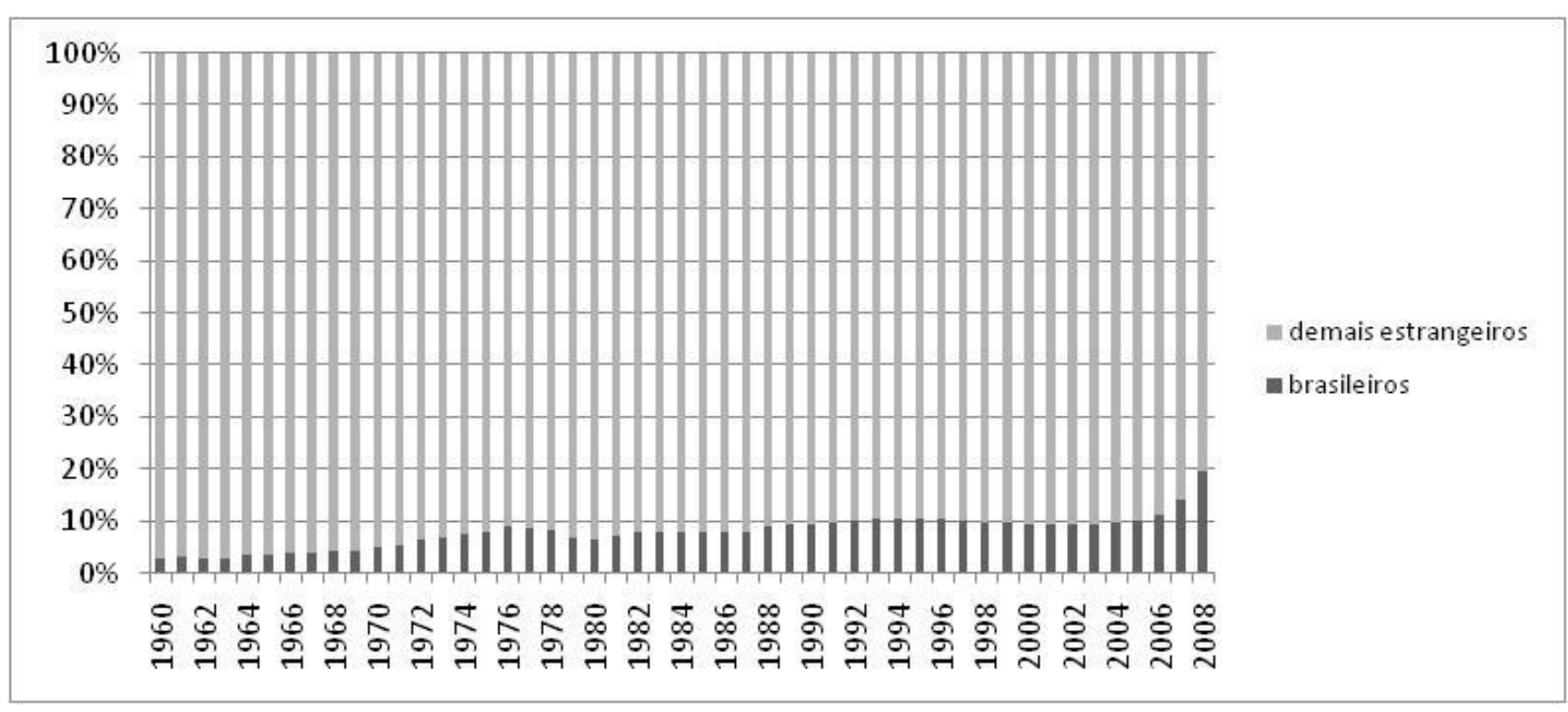

Fonte: SEF e INE.

Organização: Aline Lima Santos

Conquanto se esteja considerando apenas os imigrantes regulares, é possível inferir com base nesses dados a relação direta entre situação econômica e política brasileira e emigração. Até meados da década de 1990, houve crescimento da comunidade brasileira em Portugal, ao passo que o Brasil enfrentava profunda crise econômica e política. $O$ depoimento a seguir de uma imigrante brasileira que chegou a Portugal em 1991 evidencia isso:

"Eu vim pra Portugal numa altura em que... Eu tava com aquela briga, porque o presidente era o Collor de Mello e em São Paulo eu tinha que optar entre Maluf e Fleury. Eu achei que era um peso muito grande pra mim. Eu falei: “- Não, é muito pra minha cabeça!". (...) Foi numa época que estava mesmo complicado"'.

A entrevistada afirma que dentre suas motivações principais estava a desilusão política. Acrescenta a isso também a precarização de suas condições materiais, relacionada à crise econômica no país. Nas suas palavras:

\footnotetext{
${ }^{7}$ Entrevista com imigrante. Mulher. Atendente. Lisboa, pesquisa de campo, outubro de 2009
} 
“(...) Desilusão política e a economia do país que estava com aquela inflação galopante, nada chegava, entendeu? Por exemplo, como eu já não morava mais na casa dos meus pais, eu estava mudando muito minha maneira de morar, sabe?! Cada vez mais... Era uma regressão pra mim... Aí eu falei: "- Não, não vale a pena".

Houve, portanto, uma primeira onda da migração brasileira para Portugal que vai dos anos 1980 até meados da década de 1990. Nesse período a presença brasileira caracterizava-se predominantemente por uma distribuição mais concentrada no norte litoral, evidenciando sua essência de refluxo, manifestada também na porcentagem da população não ativa nessa comunidade, a qual em 1991 chegava a 48\%. A população não ativa era composta principalmente de esposas e filhos de portugueses que retornavam para Portugal.

De maneira geral, essa comunidade era formada por pessoas oriundas da classe média, possuíam elevado nível de instrução. Dentre os $52 \%$ que trabalhavam, a maior parte lograva engajar-se em segmentos compatíveis com sua formação. Nesse período era comum a presença brasileira em segmentos do mercado de trabalho que exigem alta qualificação.

Nota-se pequena queda da participação de brasileiros no total de estrangeiros com autorização de residência em Portugal a partir de 1994 até 2002, como se pode notar nos gráficos 9 (Evolução do número de brasileiros com autorização de residência (A. R.) em Portugal no período de 1980 a 2008) e 10 (Evolução do percentual de brasileiros com autorização de residência (A. R.) em Portugal no período de 1960 a 2008). Contudo sua importância relativa não foi alterada substancialmente. Em termos absolutos, houve crescimento contínuo dessa população até 1996, embora se deva apontar a queda no ritmo desse crescimento a partir de 1994. Em 1997 e 1998 nota-se a leve diminuição dessa comunidade, que volta a crescer em 1999.

Em 1994, a estabilidade econômica trazida pelo Plano Real diminuiu o ritmo da emigração para Portugal, levando a diminuição da comunidade brasileira em 1997 e 1998. Nesse período verificam-se os resultados "benéficos" do Plano?.

\footnotetext{
8 lbidem.

9 Bacha (1997) demonstra os significados iniciais do Plano Real tanto para a classe média, como para a estrutura produtiva brasileira, evidenciando suas fragilidades nos momentos de crise internacional.
} 
No entanto, na segunda metade da década de 1990, o mundo enfrentava graves crises financeiras, nomeadamente, a do México (dezembro de 1994), da Ásia (outubro de 1997) e da Rússia (agosto de 1998), economias que dependiam, assim como o Brasil, de capitais estrangeiros para financiar os déficits comerciais e as contas do governo. Tais crises evidenciaram a vulnerabilidade do Brasil diante dos fluxos de capitais internacionais, muitas vezes meramente especulativos.

Esse contexto turbulento para a economia foi enfrentado no Brasil adotando-se um sistema cambial mais flexível, isto é, desvalorização do real frente ao dólar, o aumento na taxa de juros e o corte dos gastos do governo. Tudo isso colaborou para a estagnação do crescimento econômico e o aumento da taxa de desemprego, a qual atingiu 19\% em junho de 1998, no estado de São Paulo (DIEESE, 1998).

É justamente nesse momento de incertezas, que caracteriza a economia brasileira na segunda metade dos anos 1990, que o IED português ganha expressividade aí. Tal como afirma Silva (2002):

"Efectivamente, só a partir de 1995 despertou em Portugal um movimento muito forte no sentido de se investir no Brasil. (...) Concentremo-nos no conjunto do período 1995-2001, quando o IDPB (investimento direto de Portugal no Brasil) atingiu 10180 milhões de euros (13247 milhões em valores brutos), tornando o Brasil, de longe, o seu principal destino (...) Os fluxos acumulados em 1996-2001, colocaram Portugal na posição de quinto investidor. (...) Nos três anos em que o processo foi mais significativo, 1998-2000, o IDPB representou em média anual, 2,5\% do PIB português, o que nos dá bem uma ideia da dimensão do investimento realizado no Brasil" (p. 139).

Evidencia-se assim uma nova etapa da internacionalização da economia portuguesa, marcada pelos investimentos no Brasil, resultando numa reaproximação com sua ex-colônia ${ }^{10}$. A atuação da Portugal Telecom (PT), comprando a Telesp Celular (Estado de São Paulo), foi o ápice desse processo que, no entanto, mantém-se, como nos mostra a compra do Jornal O Dia (Rio de Janeiro) pelo grupo português Empresa Jornal Económico (Ejesa), em abril de 2010.

\footnotetext{
${ }^{10}$ Desde os anos 1970 as relações econômicas entre o Brasil e Portugal são marginais e instáveis para ambos, em 1992 registra-se um mínimo histórico das trocas. A partir de então, as relações econômicas se intensificam, especialmente por meio do comércio bilateral e do aumento de laços econômicos e financeiros. (Silva, 2002).
} 
Tais circunstâncias deram um novo fôlego ao fluxo de brasileiros para Portugal. Essa comunidade avolumou-se novamente em 1999, o que irá culminar no aumento de sua participação no total de estrangeiros em Portugal a partir de 2002. Observa-se, no gráfico 7, um grande aumento dessa presença brasileira, comparando-se 2007 e 2008, o que repercute na sua participação relativa ao total (ver gráfico 9), que salta de $15,22 \%$ para $24,29 \%$ respectivamente. Isso se deve, principalmente, à mudança na metodologia de obtenção dos dados, já mencionada.

Identifica-se nesse período pós 1998 uma segunda onda da migração brasileira. Nessa nova fase, a população ativa é dominante, representando, em $2001,74 \%$ do total da população brasileira residente em Portugal. Trata-se, então, de um fluxo majoritariamente laboral, o que irá se refletir na distribuição territorial, agora mais concentrada na área de Lisboa. O nível de instrução das pessoas imigrantes é um pouco mais baixo comparativamente à primeira onda e seu engajamento no mercado de trabalho é maior nos segmentos menos qualificados. $\mathrm{O}$ quadro a seguir sintetiza as diferenças gerais das duas ondas, as quais serão aprofundadas no capítulo 2 :

\section{Tabela 2: Diferenciação geral das duas ondas ${ }^{11}$ de migração brasileira para Portugal}

\begin{tabular}{|c|c|c|}
\hline Características & Primeira onda & Segunda onda \\
\hline Fase & Refluxo & A partir de 1998 \\
\hline Essência do fluxo & Concentrada no norte litoral & Concentrada em Lisboa \\
\hline Distribuição no território & Não dominante & Dominante \\
\hline População ativa & Classe média & Classe média e média-baixa \\
\hline Origem na estrutura social brasileira & Elevado & Médio \\
\hline Nível de instrução & qualificação & Segmentos que exigem menor \\
\hline Inserção no mercado de trabalho & qualificação \\
\hline
\end{tabular}

Fonte: MALHEIROS, Jorge Macaísta (org.). Imigração Brasileira em Portugal. ACIDI, Lisboa: Observatório da Imigração, 2007. Organização: Aline Lima Santos

\footnotetext{
${ }^{11}$ Denomina-se "ondas migratórias" os momentos de expansão dos fluxos migratórios. Salienta-se, porém que para o mesmo fenômeno, os autores portugueses, inclusive aqueles aqui citados, utilizam mais comumente a expressão "vaga migratória".
} 
Os ataques de 11 de setembro de 2001 aos EUA levaram ao acirramento do controle de suas fronteiras. O destino preferencial de muitos brasileiros torna-se de mais difícil acesso, pois são impostas novas exigências para entrada no país, dificultando, por exemplo, a obtenção de vistos.

A Europa aparece como destino alternativo. As circunstancias aí se apresentavam promissoras. O euro entrava em circulação como uma moeda forte, sua cotação a tornava mais atrativa do que o dólar. Concorda-se aqui com a idéia de que "a grande motivação é naturalmente as oportunidades de fazer dinheiro, (...) sempre com uma perspectiva de volta. O emigrante brasileiro vê a imigração como uma perspectiva extremamente temporária" (Viana, 2005). Sobre isso, afirmou a Consulesa do Brasil no Porto:

\begin{abstract}
"Na minha visão, porque que o brasileiro ainda vem para a Europa? Eles vem atrás de dinheiro. Não é porque "- Ah, porque o desemprego no Brasil está muito grande".(...) A nossa taxa de desemprego, ela é menor. (...) Então, não é exatamente uma fuga do desemprego, não é. É uma atração que vem de que, ainda, o euro é uma moeda forte. "Ainda" porque o euro está se desvalorizando no Brasil.

Quando eu cheguei há 3 anos aqui, você tinha o euro a 3,50 ou 3 reais, agora é 2,5. Então eu me pergunto se quando chegar no 2,00, aí sim, não vai atrair o suficiente" $"$.
\end{abstract}

A situação mais atual da migração brasileira para Portugal se dá no contexto de crise econômica nos países do norte. Daí que a Consulesa assinala a cotação do euro como um motivador maior do que o desemprego no Brasil, tendo em vista a conjuntura desfavorável de aumento desse indicador nos países da União Européia.

Emigrar, ganhar euros, juntar, voltar em condições econômicas e sociais mais altas na hierarquia da estrutura social brasileira: esse é o sonho, muitas vezes não realizado, já que muitos adiam constantemente o retorno, tornando a migração permanente. Mas esse sonho está inserido numa realidade mais ampla:

"Esse movimento recente de emigração é um movimento que se colocou muito para as classes médias brasileiras. (...) São as classes médias, os jovens que representam, talvez, a maior parte dessa... Frustrados pela

12 Entrevista com Dr. Cláudia d'Angelo, Chefa do Consulado Geral do Brasil no Porto, pesquisa de campo, novembro de 2009. 
situação econômica, frustrados... Frustrações também de ordem política, embora não na década de 80, mas escândalos, o governo Collor foi o ápice, com poucas perspectivas. Há todo um movimento, há toda uma onda na década de 1980 de saída pra o mundo, das classes médias. Portanto, há, não quero reduzir o fenômeno a isso, mas isso é quantitativamente muito importante. E também é preciso entender que para o brasileiro muito pobre ir para a Europa é uma perspectiva extremamente longínqua, e a Europa é um continente extremamente longínquo pro universo cultural dos estratos mais pobres da população brasileira, portanto, a vinda pra Europa, a vinda pra Portugal é uma perspectiva de quem já tem mais contatos com esse mundo culturalmente ou familiarmente. Outro fenômeno importante é que boa parte dos imigrantes, uma minoria, mas uma minoria significativa dos imigrantes aqui são netos, bisnetos e descendentes de portugueses.(...). Portanto, é um país mais próximo culturalmente do Brasil, então há uma natural opção para aquela parcela de imigrantes brasileiros que saem do Brasil". (Viana, 1995)

Essa interpretação acrescenta outros fatores, além dos que já foram aqui discutidos, que justificam a escolha de Portugal como destino, relacionados à estrutura social brasileira e à ascendência européia. A migração de brasileiros para Portugal relaciona-se a questões culturais e históricas, ou seja, são principalmente descendentes buscando os países de seus ancestrais. Curiosamente, como aponta Guerra et alli (20067), dentre os chefes de família de classe média que não nasceram no Brasil, os portugueses são os mais numerosos, o que ratifica mais uma vez a constatação de que migraram pessoas jovens de classe média e descendentes, fato ainda mais marcante na primeira vaga.

A ancestralidade lusa desempenha também um importante papel no acesso à nacionalidade portuguesa, o que também constitui uma motivação para a escolha desse destino que é tanto de acolhimento final, como uma "porta de entrada" na Europa. Sobre essa dupla característica de Portugal como destino, cabe mencionar uma conversa entre dois imigrantes brasileiros, que foi presenciada durante a pesquisa de campo, na qual um tentava convencer o outro a deixar Portugal, uma vez que já tinha conseguido, em suas próprias palavras, "o que era possível ali": a nacionalidade portuguesa, tendo assim possibilidade de migrar para Inglaterra, onde se poderia ganhar em libra e aprender inglês.

Mas, além da questão da ancestralidade, há também a proximidade cultural, expressa fundamentalmente na língua, na religião e na história em comum. Essa última é marcada por acontecimentos lembrados com 
festividades em ambos os países tais como os quinhentos anos do descobrimento em 2000, ou os duzentos anos da vinda da Coroa portuguesa ao Brasil em 2007, dentre outras efemérides (Malheiros, 2007). Uma das conseqüências de tais congruências é expressa na resposta de um imigrante brasileiro, que chegou a Portugal no ano de 2001, quando se inquiriu porque ele escolheu viver nesse país:

"A curiosidade que eu tinha de conhecer, na verdade... era um pouco curiosidade que eu tinha de conhecer.. Só isso... " - Não foi o português que descobriu o Brasil? Vamos lá ver como é que é Portugal..." E aí, no momento era uma opção de sair de certas dificuldades, daí eu aproveitei aquela curiosidade e vim..."13

Os fatores culturais, econômicos e históricos contribuem para o estabelecimento de contatos constantes entre ambas as sociedades e, de modo mais específico, entre os seus respectivos Estados. A conjunção desses elementos oferece ao migrante brasileiro em Portugal uma ampliação de sua esfera de ação e multiplica as relações possíveis (Raffestin,1993).

Se, como afirma Santos (2002), a pessoa ao se defrontar com um lugar que não ajudou a construir, esse lugar lhe é fonte de profunda alienação, quiçá seja possível inferir que os elementos comuns entre brasileiros e portugueses sejam capazes de diminuir a sensação de estranhamento. Beaujeu-Garnier (1967) assegura que "quanto maior a diferença entre a terra natal e a terra de adoção, tanto maiores as dificuldades” (p.202).

Especialmente a língua constitui-se em um recurso importante, pois é um meio de mediatizar as relações, de agir, de agir sobre o outro (Raffestin,1993). Um exemplo disso é o caso de uma imigrante entrevistada em Lisboa, a qual decidiu ficar em Portugal após ter obtido a nacionalidade italiana, que conseguiu em virtude de sua ascendência. Segundo ela, o tempo que passou na Itália para adquirir a nacionalidade foi de muitas dificuldades, visto que mesmo tendo nível de instrução elevado, não conseguiu trabalhos qualificados, pois não se comunicava bem no idioma, por isso foi para Portugal, onde trabalha satisfeita em um escritório de arquitetura e decoração.

Mas se, por um lado, a língua é um fator relevante para a escolha de se ficar em Portugal, por outro ela pode justificar a saída para um terceiro país,

\footnotetext{
${ }^{13}$ Entrevista com imigrante. Homem. Pintor. Lisboa, pesquisa de campo, outubro de 2009.
} 
como mostra a conversa dos dois imigrantes citada anteriormente. Outro brasileiro entrevistado ponderou as facilidades trazidas pela língua argumentando:

\begin{abstract}
"o que facilitou, mas que também não é um ganho, é a questão da língua, aqui você tem a facilidade, porque é o português, mas também você tem um grande ganho em ir pra outro país aprender outro idioma, isso pra tua cultura é uma riqueza (...) Então por conta disso a gente pensa que estar no país que fala o mesmo idioma é bom, mas também num outro, com outro idioma seria uma riqueza. Então estou aqui primeiro por contato, é claro, e a princípio pensava que a língua iria me ajudar muito, tem suas facilidades, quando na verdade o português do Brasil e de Portugal tem as suas diferenças, né? Como eles falam, o emprego dos pronomes, então tudo isso gera para nós um estranhamento..."14.
\end{abstract}

Outro elemento que não se deve ignorar na análise da escolha de Portugal como destino de migrantes brasileiros é o papel desempenhado pelos processos de comunicação no sentido de colaborar para a construção de certo tipo de representação simbólica do país. Há relações entre processos de comunicação, que podem ser interpessoais e midiáticos, e a constituição de fluxos migratórios (Pinho, 2007).

Os processos de comunicação interpessoais estabelecem o que comumente se designa redes sociais. No excerto da entrevista anterior, o imigrante destaca: "estou aqui primeiro por contato", enfatizando a relevância que teve conhecer e conversar com pessoas que já estavam em Portugal na decisão de migrar. Outra imigrante contou que decidiu ir viver em Portugal depois que uma tia que aí vive foi visitá-la no Brasil e disse que se ela quisesse migrar a apoiaria. Contudo, afirmou: "No fim, ela só arrumou um quarto pra gente ficar (ela e o marido)... Foi tudo uma ilusão! Tivemos que nos virar sozinhos"15. As redes sociais possuem um papel importante nas decisões, contudo, não garantem a superação dos desafios encontrados.

Para aqueles que não possuem pessoas conhecidas em Portugal, a mídia tem papel fundamental (Pinho, 2007). Por isso considera-se a atuação da mídia brasileira mais um elemento relevante da constituição do fluxo de brasileiros para Portugal.

\footnotetext{
${ }^{14}$ Entrevista com imigrante. Homem. Padre. Lisboa, pesquisa de campo, outubro de 2009.

${ }^{15}$ Entrevista com imigrante. Mulher. Empregada doméstica. Lisboa, pesquisa de campo, outubro de 2009.
} 
Para além de noticiar e divulgar as datas comemorativas em comum, a mídia ajudou a construir uma imagem de Portugal contemporâneo que teve certamente seu papel no sentido de potencializar o fluxo. Pinho (2007) analisou os conteúdos veiculados sobre Portugal pela revista Veja, no período de 1985 a 1996. A eleição dessa revista justifica-se pelo perfil do público que atinge semanalmente, o qual é bastante próximo ao perfil dos brasileiros de primeira vaga em Portugal: "imigrantes com alguma qualificação e com habilitações semelhantes às que caracterizam os públicos de recepção da imprensa escrita" (p. 61).

As matérias analisadas destacam mudanças sócio-econômicas e políticas em Portugal, enfatizando a modernização trazida pela sua inserção na Comunidade Econômica Européia. Os conteúdos renovam a imagem de Portugal "atrasado", "empobrecido" e "provinciano" que era comum e decorria da própria imigração portuguesa no Brasil, a qual denunciava um Portugal país de emigração, de repulsão (Pinho, 2007). Cabe o parêntesis de que a própria veiculação de matérias sobre Portugal advém da presença de imigrantes portugueses no Brasil (Pinho, 2007). Conforme a socióloga:

"Para alguns Portugueses residentes no Brasil (...) as informações sobre a entrada de Portugal na CEE e a eleição de Cavaco Silva terão sido condições de reavaliação dos seus percursos migratórios durante a situação global de crise (...) Não será por acaso que o primeiro Brasileiro apresentado em artigo sobre a emigração brasileira, em 1988, é precisamente um descendente de imigrantes portugueses no Brasil:

Significativamente, não é apenas o caçula Sérgio, nascido no Brasil, mas toda a família Carrasqueira que vem migrando aos poucos de volta à terra de seus antepassados. O pai de Sérgio, José, chegara ao Brasil na década de 50, junto com outros 20000 Portugueses que aqui aportaram em busca de riqueza. (...)No mesmo ano em que Portugal anunciou que ingressaria no Mercado Comum Europeu, e com isso abria suas portas à modernidade continental, o velho José transferiu todos os seus negócios para Lisboa. (Revista Veja 16/03/88)" (Pinho, 2007:p. 66).

A revista mostrava por meio de indicadores econômicos, em especial a inflação, um Portugal promissor, diferentemente do cenário descrito para 0 Brasil, país com o qual era frequentemente comparado. As comparações feitas destacavam Portugal como um país mais seguro, menos violento para se viver.

Dentre as pessoas imigrantes entrevistadas parte considerável justificou sua presença em Portugal pela questão da segurança. Muitas apontaram o 
Brasil como um país violento, argumentando que em Portugal eram incomuns os casos de seqüestro, de assaltos a mão armada, assassinatos, etc ${ }^{16}$. Uma entrevistada, afirmou: "Aqui me parece que as pessoas tem mais respeito à vida. No Brasil o que eu via nos noticiários me deixava com medo de andar nas ruas, aqui não...É tranquilo"17.

Soma-se ainda que as entrevista com imigrantes publicadas pela revista Veja evidenciavam predominantemente histórias de sucesso (Pinho, 2007). Para além dessa mídia impressa, os sucessos de brasileiros e outros imigrantes em Portugal também foram divulgados pela mídia televisiva, cujo alcance na população é mais amplo, atingindo também o público de classe média baixa da sociedade brasileira. Destaca-se, por exemplo, as reportagens do programa Fantástico, na Rede Globo de Televisão, que compuseram as séries "Aqui se fala Português", no ano de 1998, e "Me leva Portugal", no ano de 2004. A exibição desses programas coincide com a fase da segunda vaga da imigração brasileira, o que permite inferir a existência de alguma relação entre esses fatos.

O material midiático permite a obtenção de informações e cria ou desfaz ilusões, influenciando nas decisões de migrar. No caso de Portugal como destino de brasileiros migrantes vê-se que sua atuação o coloca como destino promissor.

Promissor também porque frequentemente se vê aí a possibilidade de maior acesso ao consumo, aspecto simbólico bastante salientado por alguns imigrantes entrevistados. Especialmente entre os migrantes mais recentes a possibilidade de mais fácil acesso às grandes marcas de roupas, acessórios e eletroeletrônicos é um argumento comum. Um deles, que após ter sido demitido do trabalho aproveitou o que recebeu para empreender sua migração, afirmou "com o que eu ganho aqui como pintor eu compro um tênis de último modelo da Puma, que no Brasil eu nunca ia conseguir comprar"18.

A origem desse movimento migratório para Portugal está dispersa no território brasileiro, ainda assim, entretanto, predominam pessoas vindas de

\footnotetext{
${ }^{16}$ A menção à segurança foi comum dentre as pessoas entrevistadas como um aspecto positivo de se viver nesse país em detrimento de se viver no Brasil. Contudo, deixou-se de inquirir se, no Brasil, já haviam passado algum tipo de situação de insegurança como assaltos, seqüestros, etc.

${ }^{17}$ Entrevista com imigrante. Mulher. Advogada. Coimbra, pesquisa de campo, outubro de 2009.

${ }^{18}$ Entrevista com imigrante. Homem. Pintor. Lisboa, pesquisa de campo, outubro de 2009.
} 
Minas Gerais, Espírito Santo, São Paulo e Paraná (CBL, 2007). Em Minas Gerais, o município de Governador Valadares colabora significativamente para existência desse fluxo, o que confirma ser Portugal um destino alternativo face àquele tradicional, direcionado aos Estados Unidos. De modo geral, as pessoas são provenientes das zonas urbanas.

Breves considerações sobre as estratégias de ingresso no país são necessárias. Amiúde, brasileiros entram em Portugal como turistas, para isso preparam-se para satisfazer as condições que assim os qualifique caso sejam indagados no aeroporto. As exigências impostas por Portugal são expressas nas orientações dadas pelo Consulado:

"Os brasileiros não precisam de visto para entrar em Portugal (..) por um período de até 90 dias, por semestre, nos casos de deslocações para turismo e negócios.

Os brasileiros também não precisam de visto para entrar em Portugal pelo mesmo período para cobertura jornalística ou missão cultural.

Esse prazo pode ser prorrogado em Portugal, mediante autorização do Serviço de Estrangeiros e Fronteiras, não podendo a prorrogação ultrapassar 90 dias.

A isenção de visto não exime os seus beneficiários do cumprimento de algumas formalidades de entrada no espaço Schengen.

No caso da entrada e permanência ser em Portugal, torna-se necessário apresentar ás autoridades fronteiriças portuguesas:

- passaporte com validade superior em, pelo menos, 3 meses à duração da estada prevista;

- bilhete de viagem aérea (ida e volta);

- comprovativo de alojamento;

- seguro de saúde;

- comprovativos de meios financeiros para suportar a estada, equivalentes a:

- 75 Euros por cada entrada no país, e mais

- 40 Euros por cada pessoa e dia de permanência.

Assim, para permanecer 15 dias em Portugal é necessário ter 675 Euros, o que equivale a cerca de $R \$ 2700,00$.

Pode ser recusada a entrada em Portugal, pelas autoridades fronteiriças portuguesas, aos estrangeiros que não cumpram os requisitos acima referidos".(Consulado Geral de Portugal em São Paulo, disponível em http://www.consuladoportugalsp.org.br/, acesso em 30/05/ 2010).

Nem sempre, todavia, os migrantes tem condições de adequarem-se a tais exigências, especialmente devido ao custo. Assim, surgem estratégias singulares como a descrita por um entrevistado:

"Você tem que provar alguma coisa.(...) Na verdade minha mala até voltou pro Brasil, já tava pronto pra ser deportado... Mas aí como diz, com uma mentira daqui (risos), um jeitinho dali pra você convencer...(...) 
Perguntaram o que é que eu vim fazer aqui. Eu disse pra eles que eu vim pra acompanhar uma senhora que foi operada aqui de volta pro Brasil. Daí o que é que eles disseram... Perguntaram pra mim: " - Você acha que uma pessoa que foi operada aqui, operada na Europa, voltaria pro Brasil, um local que não teria recurso"... Então, aí é onde eu dei uma rasteira neles, por que naquela altura, os portugueses estavam indo pro Brasil pra fazer transplante de rim, que aqui não fazia, tá entendendo? Você pegava o avião e tava sempre cheio de português indo pro Brasil pra fazer transplante de rim, então aproveitei joguei logo uma mentira boa na cabeça deles, né?! Porque quando ele disse assim: " ah, um local que não tem recurso", eu já disse pra ele: “ - Auto - lá!, espera aí, no Brasil, numa cidade que tem setenta e cinco mil pessoas, você tem UTI, hospital de urgência, médico de família que te atende em casa e você não precisa se deslocar de casa pra ir ao médico de família dependendo de seu estado de saúde... o médico de família vai até sua casa..." Apesar que foi uma mentira e não foi ao mesmo tempo... Por que na minha cidade... quer dizer, na minha cidade, virgula, porque eu fui criado lá em Barra das Garças, Mato Grosso, isso lá em Barra das Garças acontece, tem UTI, hospital de urgência e médico de família que atende as pessoas em casa... Quando você desaparece do centro de saúde, como... cada local tem o centro de saúde responsável por cada região, cada bairro, então eles sempre faz visita nas casas, quando você desaparece por completo eles tão sempre investigando, " - Onde é que você ta?" Se você tem um problema, vamos supor, diabetes, qualquer coisa assim, então eles estão sempre em busca pra ver se você ... Se aquilo tá controlado, tá entendendo?! Então quer dizer, não foi exatamente uma grande mentira, por que pode ser que na grande parte do Brasil tenha deficiências, mas pelo menos em Barra das Garças não tem, as pessoas são bem atendidas no centro de saúde, médico de família... Então depois que eu disse isso, o rapaz pensou bastante e disse: " - Tá bom, tem razão.."19.

Curiosamente, quando questionado se era verdade que havia alguém precisando de acompanhamento até o Brasil, o migrante foi taxativo: "essa foi uma grande mentira..."20. Entretanto, nem sempre essas estratégias são bem sucedidas, fato evidenciado nas estatísticas das entradas recusadas em território português.

Em 2008, das 3598 recusas, 2333 foram para brasileiros, o que corresponde a quase $65 \%$ do total, ou seja, ampla maioria dos recusados. A não admissão de brasileiros resulta, em sua maior parte, da ausência de motivos que justifiquem a entrada no país, como é possível notar no gráfico a seguir:

\footnotetext{
${ }^{19}$ Entrevista com imigrante. Homem. Trabalhador na construção civil. Lisboa, pesquisa de campo, outubro de 2009.
${ }^{20}$ Ibidem
} 


\section{Gráfico 10: Brasileiros não admitidos em Portugal por motivo de recusas - situação em 2008.}

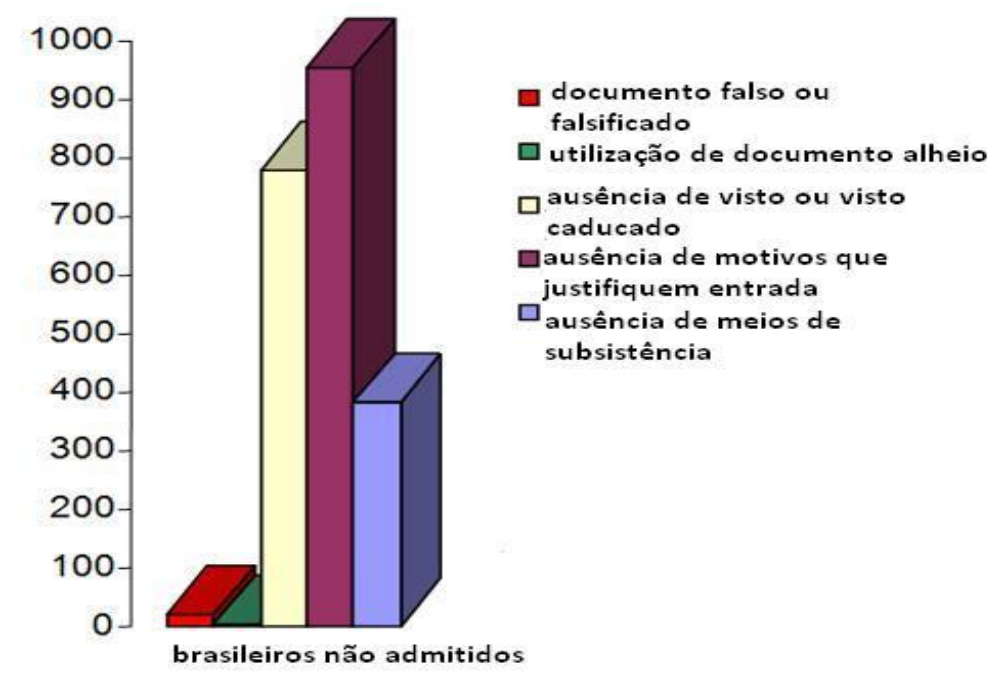

Fonte: SEF. Relatório de imigração, fronteiras e asilo, 2008. Portugal: Departamento de Planejamento e Formação, 2009, p. 54. Adaptado.

Mesmo sendo o grupo de estrangeiro que apresenta maior número de recusas, os casos de não admissão são a minoria no conjunto dos brasileiros que tentam entrar em Portugal. Isso se deve a participação desses imigrantes em redes sociais, as quais são responsáveis, dentre outras coisas, por orientar e informar acerca dos comportamentos que devem ser tomados na ocasião da entrada no país.

Essas redes sociais são frutos diretos e indiretos de uma história de relações entre o país de origem e o país de destino, que tem no trânsito de pessoas uma de suas manifestações. O papel delas é fundamental para formação e consolidação do fluxo de brasileiros para Portugal. Tal fato, além de encontrar ampla menção na bibliografia sobre o tema, foi comprovado empiricamente. A grande maioria das pessoas migrantes entrevistas conhecia alguém em Portugal: eram amigos, amigos de amigos, parentes, namorados, dentre outros. Como se observa nas citações abaixo:

"Tinha um contato lá do Brasil, proprietário dessa clínica, que fez contato comigo lá no Brasil e falou que eu poderia vir assumir uma vaga na administração, mas também temporária, pra cobrir férias de uma outra 
funcionária. E eu vim e cobri as férias dela, depois acabei ficando mais um pouquinho e vim pra cá." 21

"Vim sozinha. Mas, eu tinha amigos que moravam aqui, agora eu tenho parentes que já vieram, mas eu tinha amigos que moravam aqui". ${ }^{22}$

“(...) Eu falei bom, eu vou então para a França, que a minha amiga até então morava na França. Quando eu entrei mesmo em contato com ela dizendo: - olha, eu já tenho o dinheiro, vou fazer. Foi que ela me disse: olha eu já não estou na França. Estava aqui há coisa de dois meses, ela estava morando aqui em Portugal. Foi por isso que eu vim para Portugal, mais porque tinha essa amiga, a intenção realmente não era pra cá,23.

As decisões de migrar e as estratégias de entrada no país são ancoradas na esperança, em melhores perspectivas de vida. Mas, mesmo que as decisões sejam pautadas em informações, redes sociais, conjunturas econômicas, proximidades culturais, sociais, históricas e diversos outros fatores, a outra margem do Atlântico é repleta de incertezas. Talvez por isso seja comum as pessoas imigrantes responderem exatamente o dia, mês e ano em que chegaram a Portugal. O dia da chegada é o início de uma nova vida, repleta de possibilidades, as quais se enquadram no papel destinado aos imigrantes dado pela sociedade receptora em seu território. Cabe reflexão, portanto: como estão inseridos os imigrantes brasileiros no território português?

\footnotetext{
${ }^{21}$ Entrevista com imigrante. Homem. Dentista. Lisboa, pesquisa de campo, outubro de 2009

${ }^{22}$ Entrevista com imigrante. Mulher. Cozinheira. Coimbra, pesquisa de campo, outubro de 2009

${ }^{23}$ Entrevista com imigrante. Mulher. Atendente. Lisboa, pesquisa de campo, outubro de 2009
} 


\section{Capítulo 2 - Brasileiros em território português: oportunidades e desafios}

Deve-se não apenas constatar a existência de um fluxo migratório, mas verificar como ele se instala no território receptor contribuindo para alterações nas dinâmicas que o compõem. Convém, portanto, analisar como se inserem os brasileiros em território português ao longo dos últimos trinta anos. O ponto de partida aqui adotado é observar a composição da população residente em Portugal do ponto de vista do território, atentando com maior acuidade à distribuição da população imigrante brasileira.

De modo geral, ao crescimento absoluto da população estrangeira residente corresponde seu crescimento relativo em todos os distritos. Nota-se progressiva concentração dos estrangeiros em distritos da região sul do país (figura 6: Estrangeiros na população dos distritos, situação em 1991, 2001 e 2003), em detrimento de alguns distritos do norte, paralelamente, destaca-se a área litorânea como aquela com maior presença imigrante. Há maior expressividade da porcentagem de estrangeiros nas áreas metropolitanas do país, nomeadamente, Lisboa e Porto, contudo, no período considerado, houve tendência a dispersão desses estrangeiros no território português.

Figura 6: Estrangeiros na população dos distritos, situação em 1991, 2001 e 2003

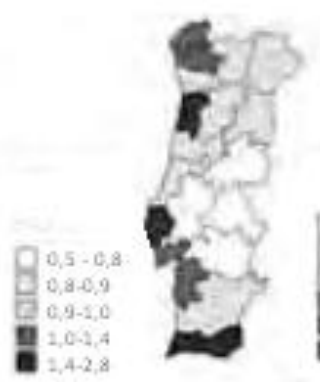

1991

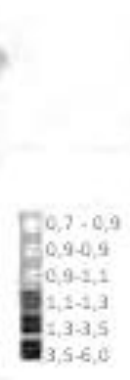$$
\text { (1) }
$$

Fonte: LAGES, Mário F. (et all). Os imigrantes e a população portuguesa. Imagens recíprocas. Análise de duas sondagens. Lisboa: Observatório da imigração/ACIME, 2006, p. 78.

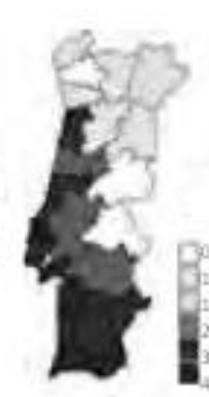

2001

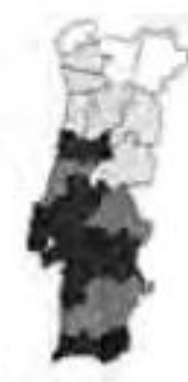

2003

Os brasileiros destacam-se como o grupo de estrangeiros mais dispersos no território. Sua distribuição é a que mais se aproxima da dos portugueses. Embora os estrangeiros concentrem-se mais no sul do país, isto 
é, na região do Algarve, os brasileiros destacam-se mais ao Norte-Litoral, como se pode observar abaixo:

Figura 7: Brasileiros na população dos distritos, situação em 2008

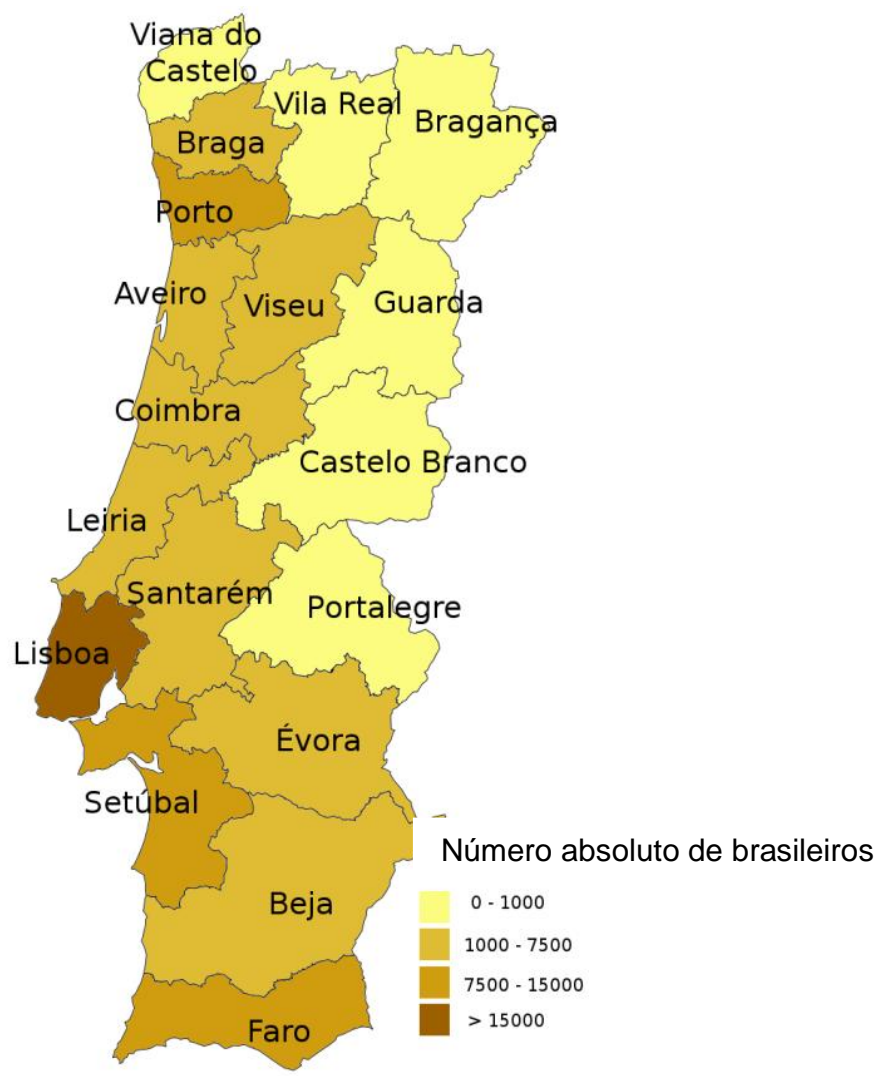

Fonte: SEF. Relatório de imigração, fronteiras e asilo, 2008. Portugal: Departamento de Planejamento e Formação, 2009.

Organização: Aline Lima Santos.

Elaboração: Germano de Castro Granda Neto.

É necessário considerar, porém, a presença brasileira em Portugal num enquadramento dinâmico. Essa configuração (figura 7: Brasileiros na população dos distritos, situação em 2008) exprime a importância do fluxo de brasileiros de primeira onda para Portugal, demonstrando a inversão da histórica emigração portuguesa para o Brasil oriunda do Norte-Litoral.

Segundo dados do INE, em 1991, o norte concentrava quase $40 \%$ desses imigrantes, os quais $18,6 \%$ encontravam-se na região metropolitana do Porto. No mesmo ano, a região metropolitana de Lisboa e Setúbal reuniam aproximadamente $35 \%$ dos brasileiros, enquanto no Centro estavam $20 \%$. Em 2001, o percentual desses imigrantes cai para pouco mais de $11 \%$ no Centro, o Norte diminui para cerca de $20 \%$, dos quais aproximadamente $50 \%$ só na 
região metropolitana do Porto, enquanto na região metropolitana de Lisboa e em Setúbal cresce para mais de 55\% (Malheiros, 2007).

Nota-se, assim, que desde a década de 1980 a região metropolitana do Porto e de Lisboa, bem como seu entorno, concentram cerca de $75 \%$ dos brasileiros no país. Porém, há tendência de maior participação da segunda em detrimento da primeira quanto ao seu percentual na distribuição dessa comunidade estrangeira. Simultaneamente, as regiões do Alentejo e Algarve também conhecem aumento da presença de brasileiros, apresentando no período de 1999 a 2004 as taxas de crescimento mais elevadas, como é explicitado na figura 8.

Figura 8: Crescimento do número de brasileiros por distritos, situação no período de 1999-2004
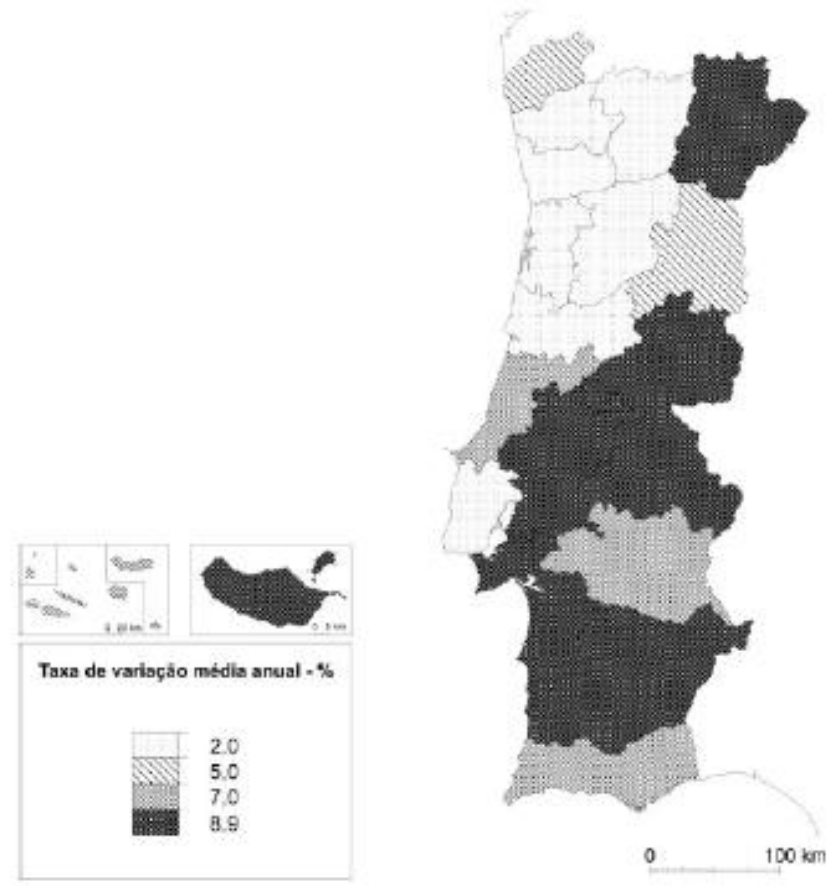

Fonte: MALHEIROS, Jorge Macaísta (org.). Imigração Brasileira em Portugal. ACIDI, Lisboa: Observatório da Imigração, 2007, p. 33.

A migração de brasileiros para Portugal no fim do século $X X$ e início do século XXI é fundamentalmente uma migração saída de áreas urbanas e direcionada a áreas urbanas. Dessa maneira, nesse país de destino, certamente as pessoas vindas do Brasil colaboram para incrementar o fenômeno de metropolização (Fonseca, 2007). 
Seguindo a tendência das demais comunidades estrangeiras aí presentes, houve nos últimos anos significativo aumento do número de brasileiros em cidades médias e pequenas. Tais cidades receberam nas últimas décadas investimentos que aceleraram seu dinamismo econômico. Assim, passaram a oferecer maiores oportunidades para trabalhadores imigrantes, o que acabou por atraí-los, resultando na sua maior dispersão. Sobre isso, Malheiros (2007) afirma:

“(...) a realização de algumas grandes obras públicas em regiões periféricas (e.g. barragem do Alqueva no Alentejo, nova aerogare da ilha do Pico nos Açores, alguns novos IP's, como o prolongamento da A23, entre Abrantes e a Guarda) contribuiu para incrementar, conjunturalmente, a necessidade de mão-de-obra, em larga medida satisfeita por imigrantes" (p. 31).

Fonseca (2007), ao tratar do mesmo assunto, reforça a análise anterior assegurando que a maior dispersão de estrangeiros recentemente notada em Portugal:

“(...) acompanha as oportunidades de emprego criadas pela dinâmica de modernização de algumas cidades médias, como Évora, Castelo Branco, Viseu, por grandes investimentos no sector das obras públicas (Porto 2001, construção de infra-estruturas desportivas para o Campeonato Europeu de Futebol de 2004, auto-estradas, barragem do Alqueva, etc.), quer pela procura de trabalhadores por alguns ramos industriais intensivos em mãode-obra, como sejam a indústria têxtil, do vestuário e do calçado, ou da agricultura, em regiões onde a oferta de mão-de-obra nacional é manifestadamente insuficiente, devido ao envelhecimento da população e à deslocação dos activos mais jovens para profissões melhor remuneradas e socialmente mais valorizadas, ou mesmo para outras regiões, dentro e fora do País, com mais oportunidades de emprego e valorização profissional e melhores condições de vida" (p. 110).

O comportamento da distribuição de brasileiros de segunda onda migratória poderia indicar progressiva diminuição da concentração dos mesmos em regiões metropolitanas de Lisboa e Porto, e aumento nas cidades médias e pequenas em um futuro próximo. Porém, visto que esse comportamento reflete as dinâmicas do mercado de trabalho, e que essas apresentam conjunturas bastante específicas, torna-se arriscado apontar essa tendência, ainda mais considerando a importância das redes sociais como um elemento relevante para decisão do "locus" de instalação no país receptor. 
As redes sociais de que fazem parte os brasileiros certamente encontram-se mais consolidadas nas áreas que tradicionalmente os recebem, o que seguramente se manterá. Mas, tendo em vista a pequena dimensão territorial de Portugal e o dinamismo econômico de outras áreas, é possível dizer que os destinos tradicionais passem a constituir-se em pontos de partida para novas trajetórias migratórias no interior do mesmo país ou para outros destinos na Europa. Pode-se inferir, portanto, que se está diante de uma ampliação da abrangência das redes sociais em território português. Essa ampliação está sujeita ao mercado de trabalho, já que o imigrante brasileiro em Portugal é, na maior parte dos casos, um trabalhador.

Sayad (1998) ao afirmar sobre a migração da Argélia para a França que "um imigrante é essencialmente uma força de trabalho e uma força de trabalho provisória, temporária, e trânsito (...) a estadia autorizada ao imigrante está inteiramente sujeita ao trabalho" (p.54), elucida também a condição do imigrante em Portugal. Daí a relevância de se atentar ao mercado de trabalho português visando compreender a inserção dos brasileiros.

\subsection{Inserção nos extremos de um mercado de trabalho dual: trabalhadores brasileiros em Portugal}

Conforme já mencionado, uma das diferenças essenciais entre a primeira e a segunda onda de imigração brasileira em Portugal é o perfil mais laboral dessa última. A isso se associa um leque cada vez maior de ocupações exercidas tipicamente por brasileiros, as quais fazem parte de nichos altamente qualificados, o que se expressa nas elevadas remunerações e valorização social, e, no outro extremo, de nichos que oferecem baixas remunerações e reconhecimento social.

Um dos resultados dos esforços de modernização realizados em Portugal é a criação de um mercado de trabalho dual, isto é, socialmente polarizado. Conforme Peixoto \& Figueiredo (2007):

"A cronologia dos modos de incorporação (de estrangeiros no mercado de trabalho) tem acompanhado a evolução da economia portuguesa, incluindo os ciclos econômicos. A modernização da economia, posterior a 1986, com 
a adesão à (então) CEE, testemunhou a entrada tanto de imigrantes qualificados como de não-qualificados (p. 110).

Em consonância com aquilo que mostra Sassen (2003) para o caso dos Estados Unidos, há em Portugal, bem como em outros países do norte, uma contenção do crescimento dos postos de trabalho que oferecem salários médios, pequeno crescimento daqueles que oferecem salários elevados e vasto aumento dos que proporcionam baixos salários. Aumentam-se, igualmente, os postos de trabalho temporários, e os chamados "part-time", isto é, trabalhos em tempo parcial, como os de meio período, por exemplo.

Esse mercado de trabalho português dual permite engajamento de estrangeiros principalmente nos dois extremos. No mais alto, observa-se, mormente, a presença de europeus e brasileiros, cujos países de origem realizaram desde 1986 até anos recentes consideráveis investimentos diretos no país. Dessa forma, existe um "fluxo de gestores e técnicos ligados às empresas transnacionais" (Peixoto \& Figueiredo, 2007: p. 110).

O Brasil foi um ator importante no processo de abertura econômica em Portugal, realizando investimentos permanentes e significativos, mantendo-se na maior parte do período de 1986-2001 em valores positivos (Silva, 2002). Mais recentemente, ações como a da Embraer, que investirá um total 148 milhões de euros na instalação de duas fábricas em Évora (Jornal Expresso PT, 2009), evidenciam a continuidade da importância do Brasil enquanto investidor. Esta ação aponta para continuidade do fluxo de brasileiros associados a grandes empresas em Portugal. Consequentemente, a manutenção da presença de migrantes brasileiros trabalhando em segmentos altamente qualificados no país.

No segmento mais baixo do mercado de trabalho português, há espaço para todos os estrangeiros, o que decorre de sua amplitude, com destaque para os africanos do PALOP. Alimentado pela modernização tal como está posta, esses segmentos tendem a crescer, afinal:

"Además de emplear trabajadores de bajo salário directamente, el expandido sector de servicios también crea empleos de bajo salário indirectamente, a través de la demanda de trabajadores para servir los requerimientos de los estilos de vida y de consumo de la creciente clase profesional y ejecutiva de elevados ingresos. La concentración de estos trabajadores de elevados ingresos en las cidades más importantes ha 
facilitado la rápida restauración de propriedades comerciales y residenciales, que a su vez ha creado una necesidad de legiones de trabajadores de bajo salário - servidores residenciales, trabajadores de restaurantes, preparadores de comida gourmet y especializada, paseadores de perros, mensajeros, limpiadores de departamentos, cuidadores de niños, etcétera" (Sassen, 2003).

Um passeio pelas ruas de Lisboa ou Porto, cidades mais importantes do ponto de vista da rede e hierarquia urbana portuguesa, permitirá perceber essa realidade. Na paisagem dessas cidades, por exemplo, vê-se a presença de serviços voltados à satisfação das necessidades dos trabalhadores de altos salários. O turismo, os restaurantes, o comércio, serviços de limpeza e construção civil são exemplos de setores cuja participação de estrangeiros, é visivelmente bastante elevada.

Esses e outros setores são preteridos pela população autóctone porque são socialmente desvalorizados, pagam mal, são inseguros, exigem baixa ou nenhuma qualificação, em suma, são bastante precários e implicam em muitas desvantagens ao trabalhador. Dessa maneira, é comum entre os portugueses a opção pela emigração ao invés da venda de sua força de trabalho a esses segmentos. Lembrando que os salários em Portugal costumam ser mais baixos que em outros países europeus, torna-se compreensível tal escolha.

A existência desse nicho no mercado de trabalho português é suprida pela população imigrante mais vulnerável, pois quem tem condições sempre busca oportunidades melhores. Assim, ele colabora para presença de imigrantes em situação irregular no interior do território.

É cada vez maior o número de imigrantes brasileiros engajados nesse segmento, sendo essa uma característica proeminente da segunda onda. $\mathrm{Na}$ primeira onda, a comunidade brasileira caracterizava-se principalmente por sua presença nos postos de trabalho altamente qualificados, embora isso ainda ocorra, notadamente em alguns setores, seu peso relativo diminuiu sensivelmente na segunda onda.

Essa tendência acompanhou uma mudança de perfil sócio-econômico dos imigrantes brasileiros. Se até meados dos anos 1990 chegavam a Portugal pessoas da classe média brasileira portadores de elevada qualificação, isto é, graduados e pós-graduados, a partir do fim dessa mesma década chegam também pessoas da classe média baixa com instrução média. Embora, de 
maneira geral, os imigrantes brasileiros apresentem mais anos de estudo que a população portuguesa, é cada vez mais difícil engajarem-se em postos de trabalho que aproveitem essa qualificação, sendo esta, igualmente, um elemento diferenciador das duas ondas dessa imigração.

Estima-se que em 2001 a participação das pessoas com elevados níveis de instrução no total dos imigrantes brasileiros era de 14,4\%, em contrapartida, a mesma relação referente a população portuguesa era de 5,9\%. Existe, todavia, um descompasso, pois quase $40 \%$ dos brasileiros que dispõem de alta qualificação não desempenham atividades correspondentes ao seu perfil educacional no mercado de trabalho (Góis \& Marques, 2007).

Dos que conseguem se inserir em grupos profissionais compatíveis com sua elevada formação, grande parte, como vimos está associada aos quadros das grandes empresas, desde os anos 1980. Mas, concomitantemente, fizeram parte também da primeira onda profissionais que migraram de modo independente e engajaram-se na área da saúde, como enfermeiros e dentistas, de informática, marketing (especialmente marketing político) e publicidade, dentre outros.

Esses profissionais supriam as necessidades do mercado de trabalho, já que o país possuía poucos recursos humanos disponíveis para o exercício dessas atividades. A insuficiência de mão de obra na área da saúde, por exemplo, era decorrente do restrito sistema de admissão nas faculdades, que levou a um lento crescimento do número de médicos em paralelo com o envelhecimento desse grupo profissional. Além disso, a melhoria geral do nível de vida em Portugal verificada nas últimas três décadas aumentou o envelhecimento populacional e a expectativa de vida, resultando no acréscimo da demanda por serviços de saúde (Peixoto, 2007).

Decorre daí que a participação de estrangeiros que trabalham na área da saúde em Portugal é significativa, representando, no ano de 2009, 11\% dos profissionais inscritos na ordem dos médicos, 11\% na ordem dos dentistas, e $3,37 \%$ dos inscritos na ordem dos enfermeiros. A evolução dos estrangeiros inscritos nessa última revela que no período de 2003 a 2009 (Gráfico 11: Evolução de estrangeiros inscritos na Ordem dos Enfermeiros, situação de 2003 a 2009) houve queda tanto em números absolutos quanto em números relativos, passando de 2298 (5,22\%) para 2018 (3,37\%). É provável que isso 
indique menor necessidade do mercado de trabalho português, em virtude do maior investimento na capacitação de pessoas nessa área, ou incremento do número de estrangeiros que não se encontram inscritos na ordem.

Gráfico 11: Evolução de estrangeiros inscritos na Ordem dos Enfermeiros, situação de 2003 a 2009

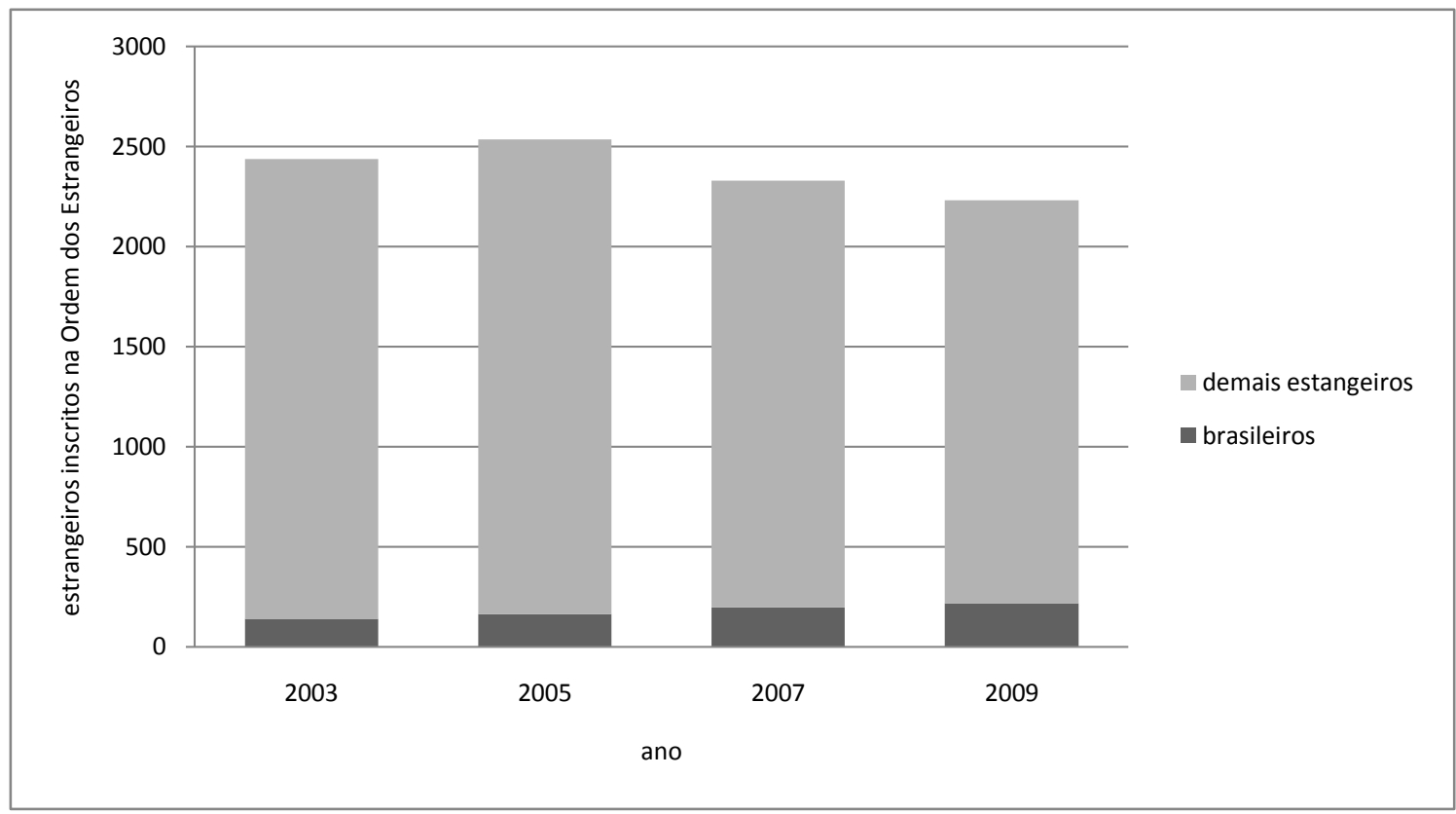

Fonte: Ordem dos enfermeiros. Dados Estatísticos 2000-2009. Janeiro, 2010. Texto disponível em http://www.ordemenfermeiros.pt/membros/Documents/OE_Dados_Estatisticos_2000_2009_VFinal.pdf, acesso em 25 de junho de 2010.

O gráfico 11 (Evolução de estrangeiros inscritos na Ordem dos Enfermeiros, situação de 2003 a 2009) evidencia que a presença brasileira na Ordem dos Enfermeiros não acompanhou a queda registrada entre o total dos estrangeiros. Se em 2003, sua participação era de 6\%, em 2009 sobe para $10,65 \%$, refletindo igualmente um aumento do número absoluto. Daí, infere-se que mesmo no período da segunda onda, a presença de brasileiros enfermeiros em Portugal solidifica-se, mantendo-se relevante.

De acordo com dados publicados pelo Diário de Notícias (2009), os médicos estrangeiros inscritos na Ordem dos Médicos de Portugal correspondem a $11 \%$ do total em 2009 , desses, quase $16 \%$ são brasileiros. Comparativamente, em 2002, o percentual dos brasileiros era de 9\% (Góis \& Marques, 2007). No período de 2002 a 2009 os demais estrangeiros também 
incrementaram sua participação em relação ao total, fato que pode decorrer da ainda insuficiente oferta dessa mão de obra na população portuguesa.

Quanto à saúde bucal, os estrangeiros inscritos em 2010 na Ordem dos Médicos dentistas somavam 6595 pessoas, o que representava $11 \%$ do total de inscritos e era composto por 29 nacionalidades, a mais numerosa delas, a brasileira (68\%). Em 2006, cerca de 15\% dos médicos inscritos na instituição eram estrangeiros, 10,64\% eram brasileiros, os quais constituíam o grupo estrangeiro mais relevante no total de estrangeiros $(69,77 \%)$.

Nota-se, portanto, uma perda de representatividade de estrangeiros e brasileiros, em particular. Contudo, é inegável a relevância de ambos nessa área profissional. A relação entre população e médicos dentistas é menor nas áreas que mais concentram imigrantes. Em outras palavras, essas últimas são menos carentes e até mesmo saturadas quanto à disponibilidade desses profissionais (Ordem dos Médicos Dentistas, 2010).

Os dados supramencionados seguramente estão aquém da real participação dos estrangeiros nesses segmentos do mercado de trabalho, pois nem todos estão inscritos nas ordens e associações que representam o grupo profissional do qual são membros. Ainda assim, permitem captar com alguma amplitude o fenômeno analisado.

O uso desses dados aqui se relaciona com o reconhecimento de que essas instituições desempenham papel central na definição dos processos de reconhecimento de diplomas, formação e competências. Logo, elas tem poder de facilitar ou não a inserção de imigrantes altamente qualificados em postos de trabalho compatíveis com seu nível de instrução e especialidade. Góis \& Marques (2007) vão mais longe no raciocínio, destacando a burocracia no processo de equivalência de diplomas e o corporativismo nacional de algumas ordens profissionais como ameaças a serem enfrentadas por Portugal, se o país quiser aproveitar de modo satisfatório esses recursos humanos que chegam "gratuitamente" ao seu território ${ }^{24}$.

\footnotetext{
${ }^{24}$ Toda a discussão sobre as imigrações altamente qualificadas em Portugal é feita por Góis \& Marques (2007) a partir de um panorama das teorias econômicas das migrações. Os autores oferecem explicações diacrônicas sobre os conceitos de brain drain, brain gain, brain waste e outros utilizados para elucidar as implicações tanto em países de origem como em países de destino da saída e entrada, respectivamente, de migrantes altamente qualificados. $\mathrm{O}$ conceito de capital humano é central nessas teorias, as quais enfatizam as características do mundo globalizado, em especial a relevância das tecnologias da informação e comunicação e a ação das empresas transnacionais, as quais facilitam esse tipo específico de circulação de pessoas.
} 
O corporativismo dos dentistas portugueses ficou explícito nos embates travados com os dentistas brasileiros. Os conflitos entre ambos foram amplamente divulgados pela mídia, ganhando destaque tanto no país de origem como no receptor, inclusive porque chegou a causar incidente diplomático na década de 1990. O principal argumento entre os portugueses para dificultar os processos de reconhecimento das habilitações acadêmicas e profissionais dos dentistas brasileiros era que em Portugal a formação do dentista é uma especialização da faculdade de medicina. Trata-se assim de médico-dentista, fato que não ocorre no Brasil. Explicando os fundamentos da crise dos dentistas um português entrevistado em pesquisa de campo afirmou:

\begin{abstract}
"É muito simples: concorrência (risos)... Havia uma crise real e uma crise legal. A crise real era que os dentistas portugueses estavam completamente ultrapassados, eram horríveis... E começaram a sentir, digamos assim, os "calos apertados" pela onda de dentistas brasileiros que tinham uma formação muito melhor, tratavam melhor as pessoas, etc. etc. Mas havia também uma fundamentação legal, em que os dentistas portugueses se apoiavam naquela altura: a odontologia era uma especialização da medicina, isto é, como é a cardiologia, como é a pediatria, era feito o curso de medicina total e depois fazia especialização em odontologia. Os dentistas brasileiros não eram assim, então os portugueses usavam esse argumento legal para tentar barrar e criar uma reserva de mercado para eles e obviamente não tinha como funcionar, porque havia muita falta de dentista em Portugal e muita falta de dentistas de qualidade, mas agora já está resolvido,25.
\end{abstract}

O caso dos dentistas brasileiros em Portugal foi resolvido com novo acordo para o processo de equivalência do diploma. Um dentista brasileiro, entrevistado, que vive há três anos no país, informou:

"Eles exigem que se faça uma equivalência... Você tem que ir a faculdade, fazer um ano, às vezes, dois anos de curso, acrescentando carga horária, pra conseguir"26.

Questionado se tinha realizado todos esses trâmites burocráticos em Portugal, ele revela que exerce sua profissão sem ter o seu diploma devidamente reconhecido: "Não fiz (a equivalência do diploma), mas tem muita gente ai que faz... Eu particularmente não fiz... E não pretendo fazer porque

\footnotetext{
${ }^{25}$ Entrevista com português retornado do Brasil. Lisboa, pesquisa de campo, outubro de 2009.

${ }^{26}$ Entrevista com imigrante. Homem. Dentista. Lisboa, pesquisa de campo, outubro de 2009.
} 
meu objetivo é outro"27. Perguntou-se, então, se isso não Ihe trazia algum prejuízo ou problema. Sua resposta sugere que existe certa conivência com essa situação, já que seu caso é bastante comum. Em suas palavras:

\footnotetext{
“Até esse momento não me trouxe nenhum prejuízo.

Mas poderia trazer... a partir do momento que visse a Ordem dos médicos. Metade da clínica tem a outra metade não tem... Mas eu acredito que essa é uma articulação que...Eu acredito que se permite... Sabem... Mas legalmente eles teriam que ver porque o processo burocrático para a equivalência é muito demorado. Pra mim que estou aqui temporariamente não interessa..."28
}

Levando-se em conta a existência de uma população em situação irregular e precária, com menores condições de arcar com os custos de tratamentos dentários, é provável que exista certa permissividade do exercício dessa profissão de modo irregular. Tal fato implica no oferecimento de serviços de mais baixo custo à população em geral e, portanto, na maior acessibilidade aos mesmos.

A respeito dos preços cobrados pela clínica em que trabalha, o entrevistado afirma que, comparativamente os preços são mais baixos e, prossegue:"Por ser mais baixo o preço acho que a gente acaba atraindo bastante migrantes, mas também atendemos muitos portugueses" 29

A clínica na qual trabalha este entrevistado apresenta boas condições, emprega elevado número de estrangeiros e atende, como ele mesmo destacou, migrantes e portugueses. Contrariando a fácil associação entre precarização do trabalho e imigração irregular, o caso evidencia que é possível encontrar médicos-dentistas trabalhando em condições irregulares em Portugal, ainda que sejam imigrantes regulares ${ }^{30}$. Isso ocorre porque, mesmo sendo mais comum, nem sempre a autorização de permanência ou residência no território é concedida por motivo de trabalho.

A área da comunicação e informação em Portugal, bem como a área da informática, são outros setores que merecem também maior acuidade, porque igualmente são marcados pela presença brasileira, em especial a partir do fim

\footnotetext{
${ }^{27}$ Ibidem

28 lbidem

29 Ibidem

${ }^{30} \mathrm{O}$ referido imigrante é formado em odontologia no Brasil, onde também se graduou em história. Em Portugal, quando entrevistado, estava terminando o mestrado e pretendia ingressar no doutorado nessa última área. Como não possuía bolsa de nenhuma instituição, trabalhava como dentista para manter-se. Sua situação em Portugal era regular, considerando que Ihe foi concedido visto de estudante.
} 
dos anos 1980 e no decorrer dos anos 1990. Tais setores foram fortemente controlados durante toda a ditadura militar e os baixos investimentos nele realizados levaram a defasagem técnica tanto dos profissionais ligados ao setor como dos materiais e equipamentos disponíveis.

O fim da ditadura militar e a abertura econômica levaram a privatização dos meios de comunicação em Portugal e a necessidade de maiores inversões em informática. Esses processos alargaram a demanda pelos profissionais com esse tipo de formação, dentre os quais os publicitários, os que trabalham com marketing, com tecnologias da informação e os técnicos em informática. Assim como no caso da saúde, essas áreas sofriam com a insuficiência de profissionais portugueses, daí a ampla participação de estrangeiros, dentre os quais os brasileiros.

Mais uma vez, os imigrantes chegam tanto como parte integrante das grandes empresas como de modo independente. Especialmente no caso da publicidade, há muitas agências brasileiras que atuam no país, como a Fischer Portugal (do grupo brasileiro Totalcom) que está no país há três anos, ou a Duda Portugal (do grupo Duda Propaganda) inaugurada no segundo semestre de 2009, para citar os exemplos recentes.

O destaque que esse grupo de estrangeiros ganhou na publicidade está ligado a tradição do setor no país de origem, que evoluiu acompanhando a expansão do consumo no pós Segunda Guerra Mundial. Na década de 1980, porém, a crise econômica e política brasileira atinge esse setor, o que fará algumas empresas buscarem alternativas no exterior. Portugal surge como destino natural, pois além de necessitar de novo fôlego nessa área, partilha a mesma língua, história, e algumas características culturais, elementos que facilitam o processo de comunicação. A publicidade brasileira hoje é uma grande referência mundial e sua presença em Portugal trouxe significativas alterações ao setor no país como nos mostra reportagem do Jornal O Estado de São Paulo (2009):

"Os publicitários brasileiros começaram a desembarcar em Portugal na década de 90, e semearam a ideia da participação em festivais. A colheita veio sendo feita ao longo dos anos, e atingiu o ápice neste ano. "Nunca a propaganda portuguesa tinha ganho tantos Leões em Cannes", diz o brasileiro Leandro Alvarez que, há 15 anos trabalha em Portugal e atualmente comanda a agência TBWA Lisboa. 
Na disputa do Festival de Cannes deste ano, Portugal conquistou 12 troféus - ou Leões, que são os prêmios mais disputados da publicidade mundial. Pode não parecer muito (o Brasil, por exemplo, conquistou 32), mas é um grande feito, levando-se em conta que, há 20 anos, essa era uma preocupação que praticamente inexistia no país. E boa parte dessa mudança é atribuída à presença dos publicitários brasileiros".

Quanto à informática, Peixoto \& Figueiredo (2007) salientam o alargamento da necessidade de trabalhadores. Isso ocorre principalmente após meados da década de 1990:

"A expansão deveu-se à disseminação das novas tecnologias e ao surgimento de fortes factores conjunturais de crescimento (o bug do ano 2000 e a introdução do euro). No campo das qualificações, o sistema educativo e profissional português só lentamente se adequou à procura, permanecendo a carência absoluta de especialistas em certas tecnologias (como, por exemplo, a linguagem IBM) (...). A incorporação de informáticos brasileiros nas empresas portuguesas (ou outras) do sector foi, então, imediata, tendo mesmo muitas accionado mecanismos directos de prospecção e recrutamento no Brasil" (Peixoto \& Figueiredo, 2007: p. 105).

Esta citação mostra que em virtude das necessidades do mercado de trabalho, há até mesmo recrutamento direto e indireto de mão de obra no Brasil tanto nas áreas de informática como na área de comunicações. Nessa última, o exemplo do processo de seleção para a agência FCB Lisboa corrobora esse fato, especificamente na área de publicidade:

Os diretores da agência pediram ajuda ao publicitário carioca Edson Athayde - que até o ano passado era o vice-presidente da Ogilvy Portugal. Em São Paulo há um mês, Athayde obteve mil respostas para o anúncio, sendo 700 delas de jovens profissionais brasileiros com experiências entre dois e cinco anos de carreira. (Jornal O Estado de São Paulo, 2009).

Assim, a inserção de estrangeiros, em especial de brasileiros no mercado de trabalho português mantém-se expressiva ainda hoje, e é facilitada pelas próprias empresas. Nesses últimos setores do qual se tratou, não houve grandes conflitos com os correspondentes profissionais da população autóctone, sendo muito difícil que isso se altere de modo significativo em um futuro próximo.

Ao contrário do caso dos dentistas, os profissionais da área de comunicação e da informática, não enfrentaram a resistência de uma ordem profissional ou outra forma de corporativismo nacional. Isso porque essas 
categorias profissionais eram bastante incipientes no país. Não estavam, portanto, significativamente organizadas.

No que se refere à publicidade "a incorporação destes profissionais não suscitou quaisquer problemas, dada a expansão deste ramo de actividade, a sua competência geralmente reconhecida e a escassa regulamentação do sector (que impediu processos formais de reconhecimento de credenciais)". Quanto à informática, por sua vez, "a ausência de regulamentação acadêmica e profissional para a maioria das actividades informáticas impediu a existência de atritos profissionais" (Peixoto \& Figueiredo, 2007: p.105).

A importância dos imigrantes brasileiros qualificados em Portugal, em vista do exposto, embora mais aguda na primeira onda, é ainda verificada na segunda onda. Em ambas, essa categoria genérica pode ser classificada, como propõem Góis \& Marques (2007), que estabelecem três tipos específicos de imigrantes qualificados em Portugal: os altamente qualificados funcionalmente legitimados; os altamente qualificados funcionalmente ilegitimados; os migrantes internamente qualificados.

Os primeiros ocupam postos de trabalho correspondentes à sua formação e podem ter migrado para Portugal independentemente ou em enquadramentos institucionais. Os migrantes de segundo tipo chegam em Portugal independentemente e ocupam, por sua vez, posições no mercado de trabalho inferiores ao que poderiam desempenhar. E, por fim, os de terceiro tipo, obtiveram sua formação em Portugal e aí decidiram permanecer, engajando-se no mercado de trabalho tanto em posto compatíveis como incompatíveis às suas qualificações.

$\mathrm{Na}$ primeira onda, predominam os migrantes de primeiro tipo. Devido sua rápida inserção no mercado de trabalho português em segmentos apropriados ao seu nível de instrução e a maior permanência nesse território, esses migrantes tem pouca visibilidade, diluindo-se no conjunto da população portuguesa, pois se encontram integrados a essa sociedade.

Na segunda onda, por sua vez, a proporção dos migrantes de segundo tipo cresce consideravelmente. Por ser mais recente, esse grupo acaba sendo mais visível no conjunto dos migrantes brasileiros. O terceiro grupo, embora apresente certa continuidade nas vagas migratórias, na segunda, terão maiores dificuldades em conjugar satisfatoriamente formação e participação no 
mercado de trabalho, passando a fazer parte também de postos de trabalho de segmentos menos exigentes.

Em suma, essas informações demonstram que para o imigrante brasileiro qualificado que decide espontânea e independentemente viver em Portugal ser bem sucedido profissionalmente hoje, ele provavelmente demorará mais tempo para fazer convergir suas qualificações com a função que desempenha no mercado de trabalho português. Houve, portanto, no decurso das duas ondas, um prolongamento do percurso profissional nesse sentido.

Isso significa que, mais recentemente, para muitos migrantes brasileiros, a saída do Brasil e a posterior inserção em território português se dá com uma queda de seu estatuto socioprofissional em um primeiro momento. Isto é, no Brasil o último trabalho desempenhado possuía maior valorização social que o primeiro trabalho desempenhado na sociedade receptora. À medida que se permanece no território, porém, essa condição tende a ajustar-se à posição aproximada a que se tinha no país de origem.

Embora estejamos enfatizando a comunidade brasileira, observa-se que essa é uma condição geral entre os estrangeiros no mercado de trabalho português. O que alguns estudos denominam mobilidade socioprofissional seria representado, portanto, como uma curva tal como representada no gráfico a seguir:

Gráfico 12: Evolução da mobilidade socioprofissional de trabalhadores imigrantes em Portugal

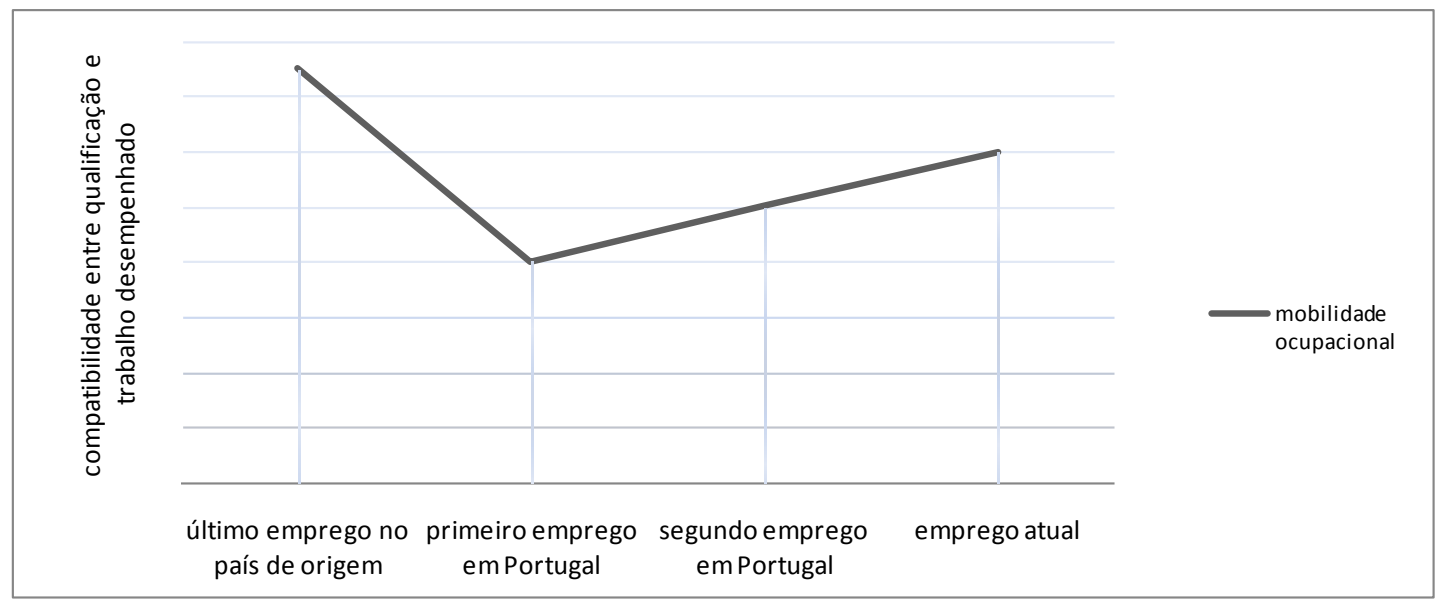

Fonte: MALHEIROS, Jorge Macaísta (org.). Imigração Brasileira em Portugal. ACIDI, Lisboa: Observatório da Imigração, 2007, p. 195. 
As distintas comunidades estrangeiras presentes em Portugal apresentam diferenciados padrões de recuperação da compatibilidade entre qualificação e função desempenhada pelo trabalhador. A queda de estatuto profissional entre o último emprego no país de origem e o primeiro emprego em Portugal é menos acentuada entre os brasileiros do que entre os imigrantes de outras origens. Por outro lado, em compensação, "são um dos grupos socioculturais com maior dificuldade de recuperação da "décalage" profissional sofrida, nos primeiros tempos de integração no mercado de trabalho português" (Malheiros, 2007: p.194).

Essa característica da comunidade brasileira refere-se, porém, a sua totalidade. Como não se trata de um grupo estrangeiro homogêneo, é necessário observar as particularidades existentes no interior da mesma. Em outras palavras, olhando-se os imigrantes brasileiros altamente qualificados, a queda do estatuto profissional entre o último emprego no país de origem e 0 primeiro emprego em Portugal é mais acentuada que a verificada entre os imigrantes brasileiros menos qualificados, os quais de maneira geral possuem instrução média (isto é, de 10 a 13 anos de escolaridade). Contudo, a recuperação do estatuto profissional, é mais provável quanto maior for a qualificação do imigrante.

Assim, ao fazer a generalização da mobilidade ocupacional da comunidade brasileira, predomina as características dessa imigração menos qualificada, a qual se avultou de modo significativo na segunda onda. Essa maior presença de imigrantes menos qualificados fará prevalecer também o engajamento nos segmentos mais baixos do mercado de trabalho, o que pode ser notado comparando-se as profissões desempenhadas na primeira e na segunda onda. 
Gráfico 13: Profissões desempenhadas pela população brasileira ativa, situação em 1991

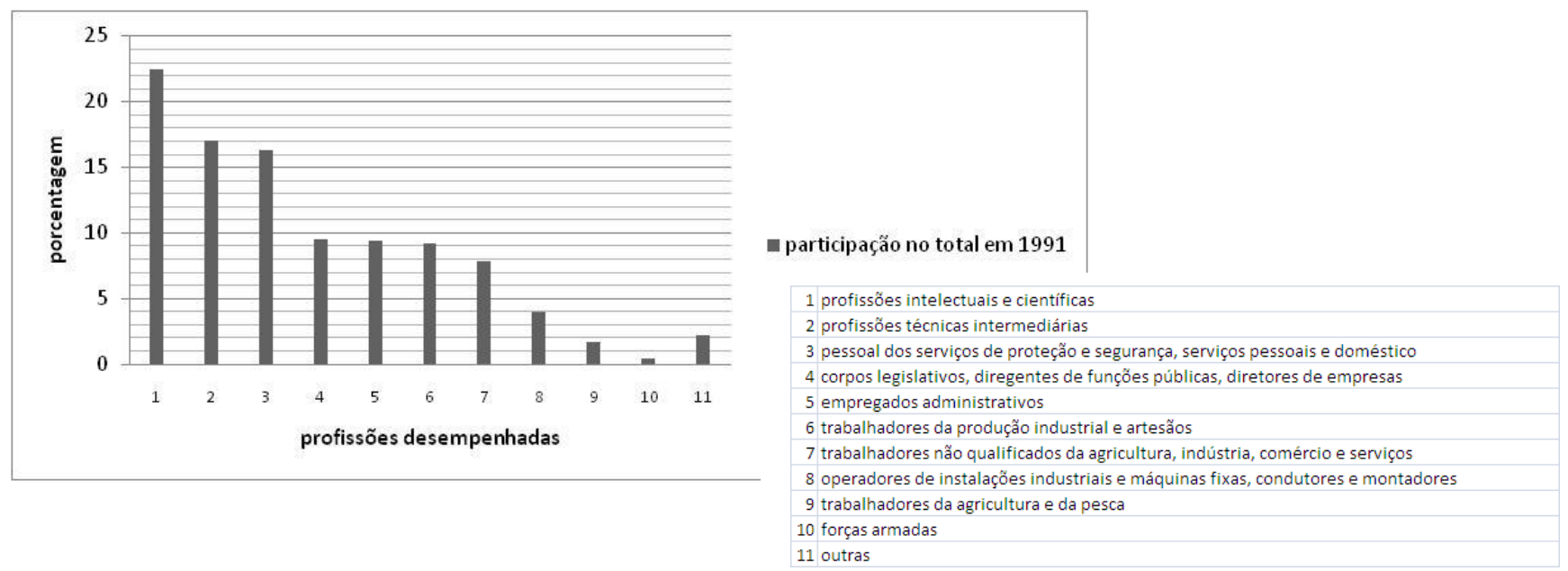

Fonte: MALHEIROS, Jorge Macaísta (org.). Imigração Brasileira em Portugal. ACIDI, Lisboa: Observatório da Imigração, 2007, p. 96.

Organização: Aline Lima Santos

\section{Gráfico 14: Profissões desempenhadas pela população brasileira ativa, situação} em 2001

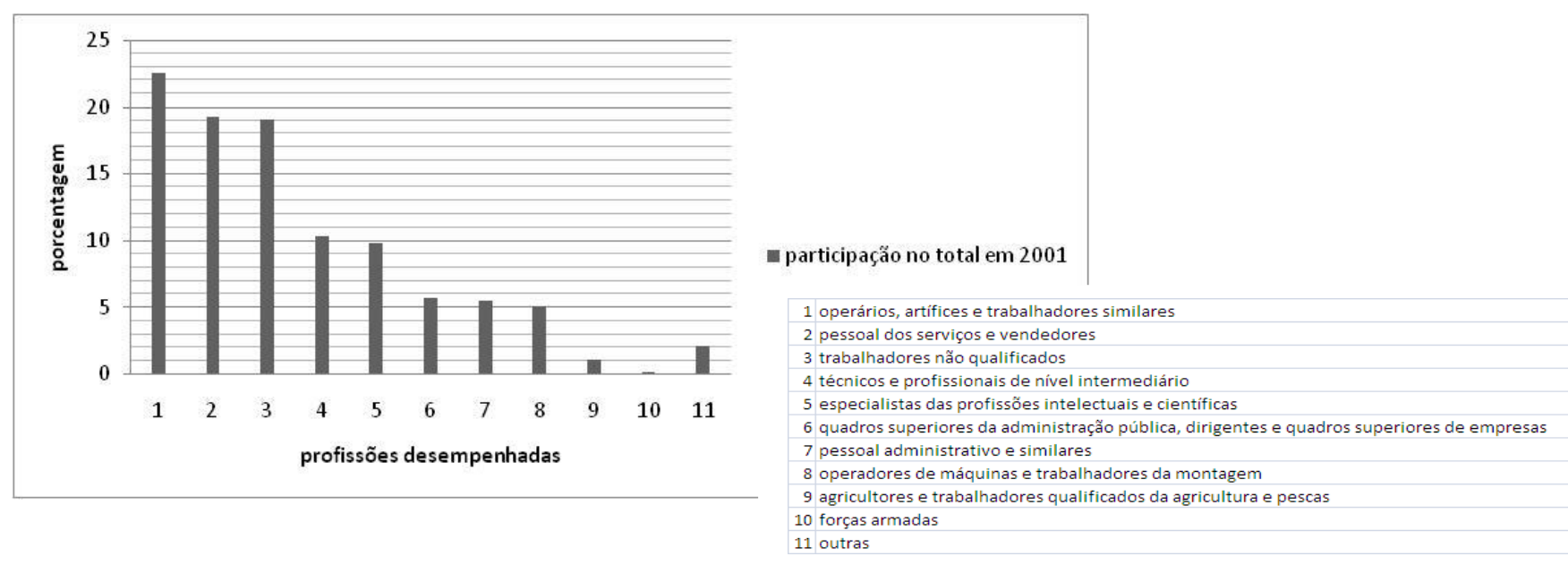

Fonte: MALHEIROS, Jorge Macaísta (org.). Imigração Brasileira em Portugal. ACIDI, Lisboa: Observatório da Imigração, 2007, p. 97.

Organização: Aline Lima Santos

Conforme dados do censo de 1991, sintetizados no gráfico 13, na primeira onda da imigração brasileira em Portugal, os trabalhadores que desempenhavam profissões de alto estatuto no mercado de trabalho, como por exemplo, as atividades intelectuais e científicas e as relacionadas aos corpos legislativos, às direções de funções públicas e diretorias de empresas, perfaziam mais de $30 \%$ do total da população ativa desse grupo de estrangeiros. Os dados do censo de 2001 (gráfico 14), por sua vez, revelam 
que a participação dos mesmos caiu para pouco mais de $15 \%$, muito embora tenha havido seu crescimento em termos absolutos, passando de 1981 para 3532 o número de pessoas que exerciam essas atividades (Malheiros, 2007).

As profissões técnicas intermediárias somadas às administrativas exemplificam a diminuição da importância das profissões de nível médio. Em 1991 , correspondiam $26,5 \%$ do total das profissões desempenhadas, enquanto em 2001, representavam 15,7\% (Malheiros, 2007).

Essa perda de importância relativa das profissões de alto e médio estatuto foi acompanhada pelo aumento das de níveis mais baixos. Os trabalhadores não qualificados, por exemplo, em 1991, representavam quase $8 \%$ do total da população ativa, enquanto, em 2001, os mesmos aproximavamse dos 20\%. Concomitantemente, cresce o engajamento nos setores de serviços, se em 1991 o pessoal dos serviços de proteção e segurança, serviços pessoais e domésticos representavam 16,3\% do total, em 2001, o pessoal dos serviços e vendedores somavam 19,2\% (Malheiros, 2007).

Em 1991 os três principais grupos de profissões em termos de participação no total somavam quase 56\%. Designadamente são eles: profissões intelectuais e científicas; as profissões técnicas e intermediárias; serviços de proteção e segurança e serviços pessoais e domésticos. Em 2001, os três principais representam mais de $60 \%$ do total. Nomeadamente são: operários, artífices e trabalhadores similares; serviços e vendedores; trabalhadores não qualificados.

Assim sendo, em 1991 a inserção de brasileiros no mercado de trabalho português era mais disseminada, já que os três principais grupos correspondiam a estatutos profissionais altos, médios e baixos, com alguma predominância para os dois primeiros. Em contrapartida, em 2001, os três principais grupos concentram-se nos estatutos médios e baixos do mercado de trabalho português, os mais altos aparecerão apenas na quinta posição.

Percebem-se facilmente os reflexos nos rendimentos médios dessa comunidade. Houve progressiva queda no decorrer do período considerado. $O$ salário médio dos imigrantes que entraram em Portugal entre 1981 e 1990 era equivalente a $€ 1527,00$, já daqueles que entraram entre 1999 e 2004 era de $€ 960,00$. Logo, constata-se que atualmente quanto maior o tempo de permanência em Portugal, maior a compatibilidade entre qualificação e função 
exercida e maior o salário obtido pelos migrantes brasileiros; enquanto os recém chegados encontram maiores dificuldades para adequar satisfatoriamente sua qualificação à função que exerce, estando sujeitos a aceitarem trabalhos que oferecem menores rendimentos (Lages, et alli, 2006).

A maior participação dos brasileiros nos setores mais baixos do mercado de trabalho português mostra a inserção desses imigrantes na primeira e segunda onda nitidamente opostas. Malheiros (2007) afirma:

\begin{abstract}
"A natureza claramente contrastante das duas vagas de imigração surge evidente (...). As ocupações profissionais da população brasileira em Portugal são quase diametralmente opostas, em 1991 e 2001. De um preenchimento de lugares mais elevados na pirâmide profissional, em 1991, como relevo para os empregados qualificados e semiqualificados dos serviços e os quadros superiores e técnicos, passamos para uma ocupação de alguns dos estratos mais baixos em 2001, com relevo para os operários industriais e os empregados de serviços, sempre com aumento da fracção de não-qualificados(...)" (p. 98).
\end{abstract}

Daí resulta, como afirma Fonseca (2007), que:

"Os brasileiros distribuem-se por um leque de profissões e atividades mais diversificadas, que incluem empresários e profissionais altamente qualificados (chegados a Portugal há mais tempo) e trabalhadores semi e pouco qualificados do comércio, da hotelaria, da restauração e da construção civil" (p. 134).

Tanto na primeira como na segunda onda, predomina a participação dos brasileiros no setor terciário. Em 1991, esse setor representava cerca de $70 \%$ das ocupações, já em 2001, cai para 60\%. Essa queda foi acompanhada pelo aumento relevante do número de brasileiros engajados em atividades industriais que passou de quase $25 \%$ para cerca de $40 \%$ (Malheiros, 2007).

A construção civil é a grande área industrial responsável pelo crescimento supra citado, fato que confirma mais uma vez a sujeição do migrante às necessidades do mercado de trabalho. O recrutamento dos trabalhadores migrantes brasileiros na construção civil está sujeito aos ciclos de crescimentos pelos quais passa o setor. O mesmo acontece em atividades ligadas ao turismo, que do mesmo modo engajam grande quantidade de brasileiros e são fortemente subordinadas a sazonalidade. Outro ponto em comum a ser destacado entre esses setores é a precariedade dos contratos e 
do trabalho e a irrelevância com as quais são tratadas as formações dos trabalhadores (Malheiros, 2007; Peixoto, 2007).

Tal característica da segunda onda migratória e da presença brasileira nesses setores do mercado de trabalho português relaciona-se a grande mobilidade horizontal na ocupação desse grupo estrangeiro. Comparativamente aos demais imigrantes, os brasileiros são um dos que mais mudam de setores de atividades, ora trabalhando em restaurantes, ora em construção civil, ora no comércio, ora em serviços domésticos, etc. Isso se dá sem melhoria de situação quanto ao estatuto sócio-profissional (Malheiros, 2007).

Essa mobilidade é muito maior do que aquela notada no mesmo setor de atividade, ou seja, mobilidade vertical, na qual o migrante passa a ocupar postos de trabalho cada vez mais elevados do ponto de vista da valorização social (Malheiros, 2007). Cabe ressaltar, porém, que essa mobilidade vertical existe, especialmente entre os que possuem elevadas qualificações.

O amplo leque de ocupações realizadas pelo grupo de brasileiros que vivem em Portugal expressa a relativamente longa duração dessa migração no país e sua inserção recente extremamente flexível no mercado de trabalho. Disso resulta que a taxa de desemprego caiu de $9 \%$, em 1991, para 7,5\%, em 2001, enquanto a taxa de atividade subiu de 48,4\% para quase $75 \%$, respectivamente (Malheiros, 2007). O perfil atual da imigração brasileira em Portugal acaba por fazer-se sentir no trabalho desenvolvido pelos Consulados Brasileiros. Conforme a Cônsul-Geral do Brasil no Porto:

"Nesse momento nós estamos com um fluxo de brasileiros de mais baixa escolaridade. Então, o pouco que recorre ao Consulado, que é o que eu posso avaliar, não há dados exatos quanto a isso, são pedreiros, domésticas, motoristas, garçons, essa parte toda de restauração, um nicho muito, muito grande de brasileiros. E um nicho muito interessante é o de lavadores de carros, não sei se você percebeu, aqui todo lavador de carro é brasileiro, parece que vai um chamando o outro. Então, eles vêem para o trabalho, naquele espaço em que o português vai abandonando. (...) $O$ espaço em que o português deixa, (...) de trabalhos braçais, o brasileiro então ocupa. Então a experiência é que você não vê muitos brasileiros desempregados. Eles ganham pouco, trabalham muito, mas quase não ficam desempregados" ${ }^{31}$.

31 Entrevista com Dr. Cláudia d’Angelo, Chefa do Consulado Geral do Brasil no Porto, pesquisa de campo, novembro de 2009. 
O relativamente baixo desemprego notado entre os brasileiros é, contudo, maior do que o verificado na população residente. Nota-se que em 2001, a taxa de desemprego para essa última era de 4,1\%. A maior proporção de desempregados entre os estrangeiros de modo geral é presente ainda hoje, no último trimestre de 2009, por exemplo, enquanto os portugueses registravam taxa de desemprego em 4,8\%, taxa de atividade em 62,4\% e taxa de inatividade em $32,8 \%$, as pessoas nascidas fora de Portugal apresentavam respectivamente 6,9\%, 72,7\% e cerca de $20 \%$ (INE, 2009).

Em síntese, os estrangeiros caracterizam-se pela maior taxa de desemprego e atividade e menor taxa de inatividade do que a população portuguesa. Isso reflete sua composição em termos de estrutura etária. Dito de outro modo, a maior parte dos imigrantes encontra-se na faixa etária correspondente à idade ativa (entre 15 e 74 anos). Essa característica geral dos estrangeiros é acompanhada pelos brasileiros.

No que se refere às horas trabalhadas pelos migrantes brasileiros, a Consulesa Cláudia D’Angelo, destaca que há elevada carga horária. Embora existam muitas dificuldades em se estimar a média de horas trabalhadas por esse grupo, há inúmeros indícios que apontam a sua superioridade comparando-as com as dos portugueses. Resultados de uma pesquisa amostral indicam:

"(...) os brasileiros e os imigrantes de Leste foram os que declararam uma duração do seu dia de trabalho mais longa. Mais de 35\% dos inquiridos destes dois grupos referiram ter trabalhado até 12 horas por dia na semana que precedeu o inquérito e 14\% dos europeus de Leste e 9\% dos brasileiros afirmaram mesmo que, em média, o seu dia de trabalho ultrapassou as 12 horas" (Lages et alli, 2006: p. 104).

Muitas pessoas entrevistadas na pesquisa de campo mencionaram o fato de trabalharem muito, ainda que se julgassem satisfeitas com o trabalho que estavam exercendo. Os trechos a seguir exemplificam:

"É um trabalho assim... Eu trabalho lá com liberdade, sabe? Faço aquilo que eu gosto, né? Que é mexer com carro. Não trabalho sobre pressão. Eu estou muito satisfeito na Renault. Eu trabalho 12 horas por dia! , $32 .^{2}$.

\footnotetext{
${ }^{32}$ Entrevista com imigrante. Homem. Mecânico de automóveis. Lisboa, pesquisa de campo, outubro de 2009
} 
Classifico a vida aqui como escravidão. Trabalho quatorze horas... Eu chego em casa uma hora e volto oito e meia da manhã até a seis da tarde, daí vou pra outra loja... é muita coisa! ${ }^{33}$.

Neste último trecho citado o imigrante afirma trabalhar até catorze horas por dia, tempo bastante superior a média de horas trabalhadas pelo total da população que trabalha em Portugal, a qual atualmente é de 39 horas semanais, isto é, pouco menos de 8 horas por dia. Assinala-se a tendência de queda desse valor: se na década de 1980 trabalhava-se em média 43/44 horas semanais em Portugal, em 2007, chega-se às já mencionadas 39 horas. A muito provável superioridade da média observada entre os brasileiros, deve-se, sobretudo, ao fluxo mais recente, e explicita a maior exploração e vulnerabilidade ao qual está sujeita essa comunidade estrangeira.

Outro aspecto a ser considerado sobre a incorporação de brasileiros no mercado de trabalho português e que é diferenciador da primeira e da segunda onda migratória refere-se à participação da mulher no fluxo migratório.

\subsubsection{A feminização da imigração brasileira em Portugal}

É cada vez maior a participação das mulheres no decorrer dos últimos trinta anos do fluxo migratório de Brasil para Portugal, em especial em fase mais recente. Em 2000, por exemplo, o número de homens superava o de mulheres em 5\%; já em 2009, o quadro se reverte, as mulheres ultrapassam os homens em pouco mais de $10 \%$.

Avaliando o total de estrangeiros, em 2000, os homens ultrapassavam as mulheres em 14\%; enquanto em 2009, mantém-se em valores mais elevados, mas diminui a diferença para pouco mais de 3\% (SEF, 2001; 2010). Conforme dados do INE (2010), no período de 1980 a 2008, a participação das mulheres imigrantes no total da população estrangeira em Portugal subiu de $40,9 \%$ para $47,6 \%$, sofrendo um incremento de $6,7 \%$, portanto.

Isso faz sobressair a tendência geral à feminização da imigração no país. Em 2008, 27,6\% das mulheres estrangeiras eram brasileiras. Desse modo, atualmente, o aumento da participação das mulheres já é um fato

\footnotetext{
${ }^{33}$ Entrevista com imigrante. Homem. Trabalhador em restaurante. Coimbra, pesquisa de campo, outubro de 2009.
} 
explícito, de proporções consideráveis e marca uma especificidade importante do fluxo aqui estudado.

Tal fato contribui para um dado das migrações internacionais contemporâneas: metade das pessoas que não vivem no mesmo país em que nasceram são do sexo feminino; em 2006 o número de mulheres migrantes era de 95 milhões de pessoas. A isto junta-se uma novidade: se historicamente as mulheres migravam com os maridos ou a eles iam reunir-se, agora se está diante do crescimento das que migram autonomamente, muitas das quais são mães solteiras, mulheres solteiras ou divorciadas (UNFPA, 2007).

Para esse fato colabora a maior aceitação social das mulheres no espaço público, o maior acesso à educação formal e sua maior autonomia para a mobilidade, especialmente no mundo ocidental, fruto de transformações diversas resultantes, dentre outras coisas, de reivindicações de movimentos feministas. Mas não é só isso. Trata-se igualmente da maior demanda pelo trabalho da mulher, decorrente da modernização tecnológica, urbanização, aumento da relevância dos serviços e conseqüente precarização do trabalho. Embora esse seja um processo geral ocorrido na Europa, América do Norte, América Latina, etc., chama atenção a particularidade dos países pobres, nos quais as mulheres estão mais vulneráveis à pobreza comparativamente aos homens.

De tais circunstâncias advém a significativa participação das mulheres nas migrações sul-norte. Motivadas por obrigações familiares, desemprego, baixos salários, limitações de oportunidades sociais e econômicas, bem como pelo desejo de fugir de tradições patriarcais e de outros fatores que restringem sua liberdade, as mulheres emigram aos países ricos na esperança de melhores condições de vida, como todo migrante, mas aí se encontram afetadas diretamente por relações de gênero.

A feminização do fenômeno migratório é, sucintamente, mais um aspecto atual processo de globalização. Como tal, partilha de um sistema complexo de dinâmicas articuladas que envolvem países ricos e pobres e as demais escalas geográficas. Uma maneira de apreender tais dinâmicas é analisando os impactos das estratégias das grandes empresas, como sugere Sassen para o caso dos Estados Unidos, o qual se extrapola para grande parte dos países ricos: 
"La inmigración y la producción offshore han evolucionado hacia mecanismos para la incorporación masiva de mujeres del Tercer Mundo a la mano de obra asalariada (...). La inmigración y la producción offshore son formas de asegurar la fuerza laboral de bajo salário y de combatir las demandas de los trabajadores organizados de los países desarrollados. También representan una espécie de equivalencia funcional: es decir, las instalaciones productivas que no pueden ser desplazadas offshore y tienen que permanecer donde está la demanda - por ejemplo, restaurantes y hospitales - pueden usar mano de obra inmigrante, mientras que las instalaciones que pueden ser desplazadas al extranjero pueden usar mano de obra de bajo salário em países menos desarrollados. Pero hay outra conexión básica y más difícil de describir. La misma serie de procesos que ha promocionado la locación de plantas y oficinas en el exterior también há contribuído a una gran demanda de empleos de bajo salario en los Estados Unidos, para los cuales los trabajadores inmigrantes son la provisión conveniente" (2003: p. 139).

Disso decorre que na maior parte dos países ricos, as mulheres imigrantes encontram principalmente oportunidades de engajamento no mercado de trabalho que condiz com padrões tradicionais daquilo que se refere ao papel da mulher nas sociedades, como na esfera doméstica, no setor de serviços, no mercado do sexo. Frequentemente, essa incorporação se dá desprovida de segurança social, em condições precárias, instáveis e mal remuneradas. Isso pode trazer conseqüências para a regularização das imigrantes em alguns países, dependendo das legislações e políticas adotadas. De qualquer maneira, mesmo sendo imigrante em situação regular, as mulheres são mais vulneráveis e sujeitas à discriminações e abusos (UNFPA, 2007).

O fluxo de mulheres brasileiras para Portugal compõe as dinâmicas sociais supramencionadas. O crescimento da participação das mulheres é mais avultado especialmente na segunda onda migratória. Assim, elas colaboram para qualificar essa segunda onda, cada vez mais concentrada na região de Lisboa e Vale do Tejo, mas também notável no Norte e no Centro do país. Estimativas demonstram que por volta de $85 \%$ dessas imigrantes encontram-se em idade ativa; a maioria é casada (aproximadamente 50\%), no entanto o número de solteiras é crescente e ultrapassa os 25\%. Majoritariamente, as mulheres brasileiras trabalham no setor de serviços, nomeadamente nas atividades domésticas, em restaurantes e atendimento ao público, e no mercado do sexo (Dias \& Rocha, 2009). 
Para compreender as peculiaridades de sua incorporação no mercado de trabalho e no território é necessário observar a situação das mulheres nesse país. O primeiro elemento a destacar é a maior proporção dessas na população: $51,6 \%$ das pessoas residentes em Portugal em 2008 era mulher (INE, 2010). Enquadrado no movimento histórico, esse número condiz com fases pretéritas, isto é, a presença das mulheres sempre foi levemente superior a dos homens na população; o que se deve, dentre outros fatores, a elevada emigração dentre esses últimos. O que há de novo no período atual refere-se à colaboração das estrangeiras. O gráfico a seguir permite inferir que as mulheres oriundas de outros países auxiliam para a manutenção desse padrão numérico, revelando que os significados do mesmo se transformaram substancialmente.

Gráfico 15: População estrangeira feminina em Portugal, evolução no período de 1980 a 2008

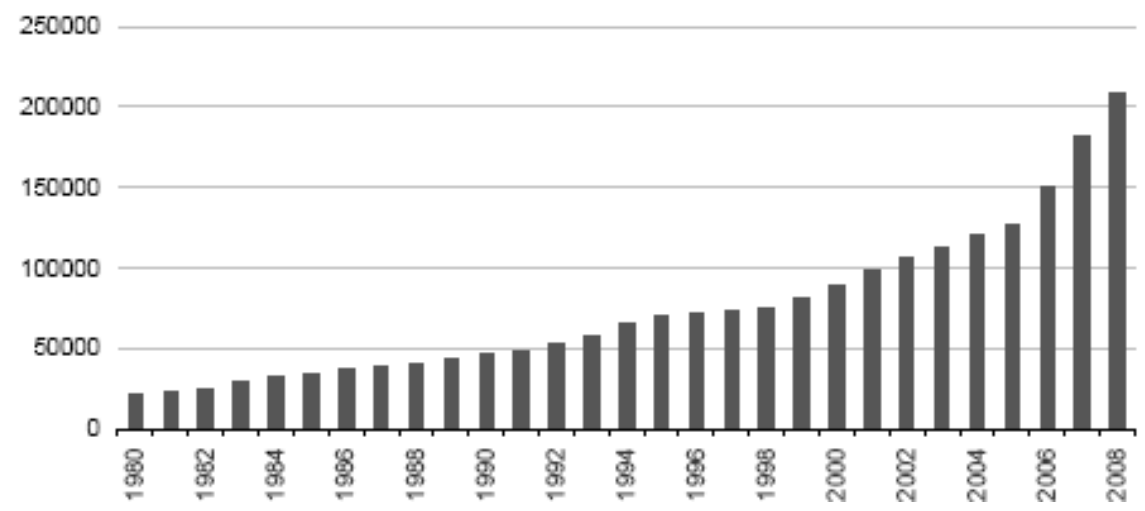

Fonte: SEF; INE, 2010.

Organização: Aline Lima Santos

A participação do contingente populacional feminino no mercado de trabalho português também sofreu incremento. A taxa de atividade entre as mulheres de 15 anos e mais era de $51,8 \%$ em 1998, subindo para $56 \%$ em 2009. A isso, soma-se o aumento da escolarização. A presença das mulheres no ensino secundário é maior do que a dos homens desde o fim da ditadura militar, no ano letivo de $2007 / 2008$ representava quase $53 \%$ do total. O mesmo ocorre no ensino superior: em 2008/2009, 53,4\% dos estudantes matriculados eram do sexo feminino. No mesmo ano letivo, $59,6 \%$ dos diplomas foram 
dados a mulheres. Essas também apresentaram crescimento entre os doutores: em 2008, eram 50,9\% dos doutorados (INE, 2010).

O crescente engajamento das mulheres no mercado de trabalho, bem como o aumento de suas qualificações escolares abalou o modelo "homem provedor" na qual se assentava a família portuguesa. As mulheres portuguesas tornam-se cada vez mais atores relevantes em termos sócio-econômicos, fruto de sua maior participação na esfera extra doméstica. Assim, de um lado, as mulheres ampliam sua autonomia e independência, o que é revelado pelo peso de seu contributo no orçamento familiar; em contrapartida, os homens perdem terreno (Sassen, 2003).

Isso se deu, contudo, em detrimento da esfera doméstica e sem que o Estado e os homens tenham assumido completamente o encargo de cuidar dos demais membros da família, nomeadamente idosos e crianças (Miranda, 2009). Daí a importância das mulheres imigrantes, que cada vez mais estão presentes nos lares portugueses e demais países do sul da Europa:

\begin{abstract}
"Elas são contratadas para substituir as figuras tradicionais das mulheres da casa, pertencentes a classes médias e altas, figuras centrais nessas sociedades, mulheres essas que agora se dedicam às suas carreiras profissionais. A execução dessas tarefas não exige qualquer qualificação e é culturalmente considerada da responsabilidade das mulheres. Elas são relegadas para a esfera doméstica de que as patroas saíram, vão desempenhar as tarefas da lida doméstica (...) em última instância, vão proporcionar bem-estar. (Ribas-Mateos, 2002:62). O seu papel é central para a família da Europa do Sul, em que continua a ser marcante a coexistência na casa de várias gerações, incluindo os jovens em idade adulta que adiam o casamento e a sua saída da casa dos pais (...)" (Miranda, 2009: p.25).
\end{abstract}

É grande a presença de brasileiras trabalhando como empregadas domésticas em Portugal. Como exemplo, podemos citar o caso de uma imigrante trabalhava para uma família formada por uma mulher portuguesa, professora universitária, e o marido, também português, engenheiro. Ambos tinham uma filha de três anos de idade. A brasileira era responsável pelos cuidados com a casa e com a criança e declarava estar satisfeita com 0 trabalho, nas suas palavras: “ - porque meus patrões são ótimas pessoas, eu 
trabalho como se eu estivesse em minha casa, trabalho normal e me sinto muito bem lá... ${ }^{34}$.

O mercado de trabalho português no período atual, como já se demonstrou, abre grandes nichos de postos para imigrantes de modo geral e mulheres em particular. $O$ setor de serviços destaca-se como o que mais oferece essas oportunidades, tanto 0 altamente qualificado como os que exigem baixas qualificações, como o trabalho doméstico, supracitado. Desse modo, as mulheres brasileiras tendem a seguir o padrão geral: engajamento no topo e na base desse mercado, sendo esse último segmento cada vez mais amplo.

No mercado de trabalho altamente qualificado as mulheres brasileiras superam a participação dos homens brasileiros (Góis \& Marques, 2007). Como já foi dito anteriormente, a participação desse grupo estrangeiro nesse segmento conta com significativa presença na área da saúde. Agregando essas informações àquelas mais gerais de que, geralmente, as mulheres imigrantes destacam-se em setores da educação e saúde, conforme assegura a UNFPA (2007), pode-se inferir que o caso das brasileiras em Portugal ratifica esse fato.

Convém salientar que aproximadamente $50 \%$ das brasileiras imigrantes em Portugal possuem ensino secundário ou ensino superior concluído, sendo $31 \%$ e $19 \%$ sua representatividade no total, respectivamente (Dias \& Rocha, 2009). Trata-se, portanto, de uma mão de obra dotada de qualificação significativa. Todavia, é certo que as mulheres brasileiras encontram dificuldades para fazer valer a correspondência entre suas habilitações e a profissão que exercem.

Essas dificuldades muito provavelmente superam as enfrentadas pelos homens brasileiros no país receptor. Embora não se tenha encontrado dados referentes às imigrantes especificamente, de modo geral, na sociedade portuguesa, as mulheres representam mais da metade das pessoas desempregadas $(54,5 \%)$ e demoram mais tempo buscando emprego. Além disso, a taxa de desemprego verificada para esse grupo da população aumentou de 6,2\% em 1998 para 10,2\% em 2009 (INE, 2010).

\footnotetext{
${ }^{34}$ Entrevista com imigrante. Mulher. Empregada doméstica. Lisboa, pesquisa de campo, outubro de 2009
} 
Há, assim, na sociedade portuguesa, uma situação geral de mais desvantagens para inserção das mulheres no mercado de trabalho do que para os homens, o que possivelmente é potencializado para a população imigrante. A isso se acrescenta a constatação geral da UNFPA (2007) de que o desemprego atinge mais as mulheres imigrantes, comparativamente aos nacionais homens e mulheres, bem como aos seus companheiros homens. Pode-se afirmar, desse modo, que existe uma hierarquia de preferências do mercado de trabalho português de modo geral, relacionada a gênero e origem, representada no esquema a seguir:

\section{Esquema 2: Preferências do mercado de trabalho português quanto à gênero e origem}

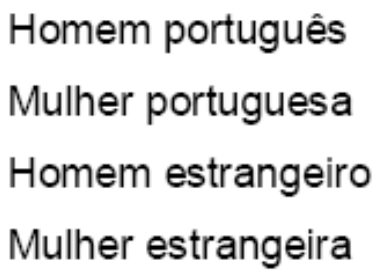

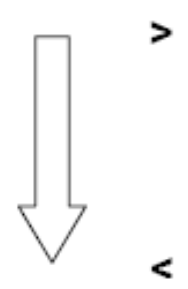

Organização: Aline Lima Santos.

Esse esquema não considera muitos fatores relevantes, como por exemplo, a nacionalidade ou o grau de instrução e a cor. De qualquer modo, ele evidencia que a mulher imigrante está propensa a status inferiores comparativamente à população nativa e ao homem imigrante. Contudo, seu status, quando confrontado ao das mulheres no país de origem é, frequentemente, mais elevado. Isso decorre tanto dos salários mais elevados que podem receber quando são recém-chegadas, mesmo desempenhando funções bastante piores do que as trabalhadoras do país de origem, como pela própria vivência no exterior, a qual é bastante valorizada socialmente no Brasil.

Todas as características aqui analisadas da presença brasileira no mercado de trabalho português expressam o status social dessa comunidade estrangeira no país receptor. A sociedade receptora reserva espaços específicos para estrangeiros, de modo geral, e no interior desses, espaços específicos para as comunidades estrangeiras em particular. Desse modo, 
migrantes de leste, africanos, brasileiros etc não terão o mesmo papel no mercado de trabalho português.

\subsubsection{Imagens do outro e a incorporação de brasileiros no mercado de trabalho português}

Aspectos simbólicos também compõem o espaço geográfico. Observar as imagens e os papéis simbólicos destinados aos brasileiros pela sociedade portuguesa em seu território possibilita compreender a incorporação desses estrangeiros em Portugal. Isso porque "segundo a situação da qual partimos, conforme nossa posição na sociedade, o grau de constrangimentos não é o mesmo" (Silveira, 2003: p.87).

A sociedade receptora sujeita os imigrantes aos seus interesses e a imagem que tem dos mesmos, dito de outro modo, aos estereótipos que cria. Partindo dessa premissa, cabe discutir os brasileiros e a hierarquia das alteridades presente na sociedade portuguesa. Qual o status dessa comunidade?

Os principais grupos estrangeiros presentes em Portugal são, como já dito, os brasileiros, os africanos originários do PALOP (Países Africanos de Língua Oficial Portuguesa) e os europeus do leste. Segundo Machado (2006) o primeiro grupo ocupa um lugar intermediário entre africanos e portugueses, já os europeus do leste ocupam posição intermediária entre brasileiros e africanos, tal como sintetizado no esquema a seguir:

\section{Esquema 3: Hierarquia das alteridades em Portugal}

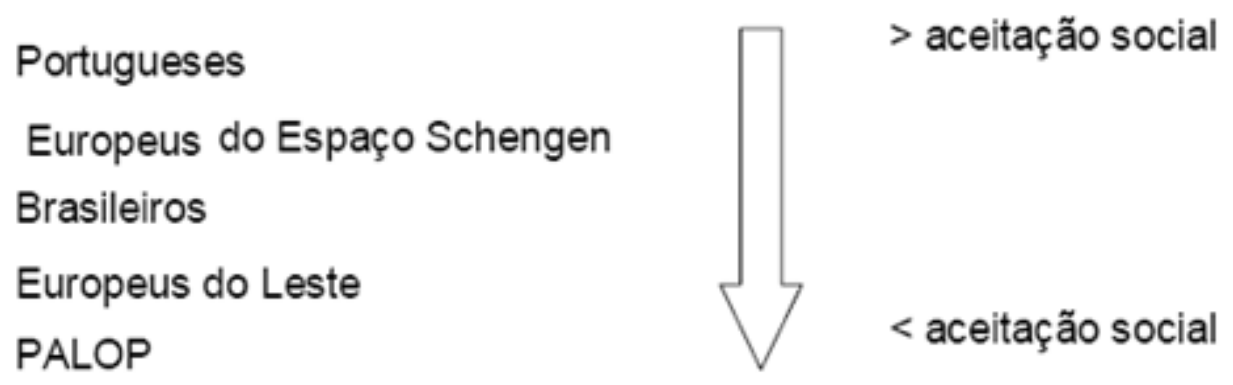

Fonte: MACHADO, Igor. "Imigração em Portugal" In INSTITUTO DE ESTUDOS AVANÇADOS. Revista de Estudos Avançados, 57. Dossiê Migrações. Vol. 20, maio/agosto 2006. São Paulo.

Organização: Aline Lima Santos 
Essa hierarquia sugerida por Machado (2006) encontra respaldo em estudo amostral que considerou os três grupos de estrangeiros mais numerosos em Portugal e concluiu que os brasileiros são aquele com o qual os portugueses mais se identificam; entre os inquiridos, cerca de $85 \%$ atribuíram características positivas a essa comunidade. Situação contrária verifica-se para os africanos, com os quais os portugueses menos se identificam; aproximadamente metade das pessoas que responderam a pesquisa associou essa comunidade a apenas uma ou nenhuma característica positiva (Lages et alli, 2006).

No quadro da aceitação da alteridade, portanto, os brasileiros representam o máximo possível, enquanto os africanos o mínimo, embora esses últimos estejam presentes em território português a relativamente mais tempo do que os primeiros. Ratificando essa constatação, os demógrafos Guedes \& Marques (2008) realizaram diversos cálculos e estimativas que os possibilitaram quantificar em cerca de $10 \%$ as chances de brasileiros ocuparem posições mais privilegiadas no mercado de trabalho português frente aos africanos.

No entanto, esses aspectos gerais da sociedade portuguesa são seguramente imbuídos de reducionismos, como são todas as generalizações. Isso fica evidente no relato de uma imigrante brasileira que afirma:

"Já trabalhei em um restaurante uma semana e o patrão me mandou embora porque eu era brasileira e a cozinheira, era angolana, e ela não queria brasileiros trabalhando ali... Como ela trabalhava lá há 5 anos, ele me dispensou...,

Há interpretações sociológicas interessantes para esse fato, porém não se deterá exaustivamente a elas. $O$ empenho aqui presente é o de destacar que os estereótipos associados aos migrantes fazem desaparecer sua diversidade e, ao mesmo tempo, os predispõem simbolicamente a cumprirem determinadas funções em território português, o que se evidencia no mercado de trabalho.

Tais relações simbolicamente assimétricas não podem ser dissociadas das relações entre o país de origem e o país de destino. Todo esse arcabouço

\footnotetext{
${ }^{35}$ Entrevista com imigrante. Mulher. Empregada doméstica. Lisboa, pesquisa de campo, outubro de 2009
} 
de imagens recíprocas de uns para com os outros são transpostos para as experiências concretas e cotidianas dos imigrantes e culminam em formas diferenciadas de discriminação, exploração e dominação. Por esse motivo Sayad (1998) dirá em sua análise que a migração e a colonização são fenômenos correlatos, para esse autor:

"O imigrante (...) é portador, tem sempre consigo ou junto de si a marca do estatuto e da posição atribuídos a seu país na escala internacional dos estatutos e das posições políticas, econômicas, culturais, etc. A esse título, nada do que possa acontecer com ele num país estrangeiro, nada do que possa fazer, nada no tratamento que possa receber, que não seja atribuído ao seu país - neste sentido, ele é plenamente seu representante, 0 representante de um país dominado, o que faz com que seja duplamente dominado, como estrangeiro que deve morar e atuar em território de soberania estrangeira e à qual é estranho, e como oriundo de um país ele mesmo dominado. (...) Um imigrante não é apenas o indivíduo que é, ele é também, através de sua pessoa e pelo modo como foi produzido como imigrante, o seu país" (p.241).

É importante notar, portanto, que o trânsito de pessoas entre Brasil e Portugal tornou esses países bastante ligados, mas também colaborou para formação das diferenças e de conflitos existentes entre brasileiros e portugueses, o que repercutiu nas imagens e representações que ambos criaram de si e do outro. Machado (2006), por exemplo, associa a posição privilegiada dos brasileiros a resquícios do pensamento colonial português ainda hoje presentes nessa sociedade. Resulta, portanto, da histórica relação entre ambos. Silva \& Schiltz (2007) ratificam este posicionamento, ao afirmarem:

"As representações mudam no espaço e no tempo mas veiculam estereótipos e "tradições". A história (sempre irregular ao nível social e das relações de poder) entre os dois grupos influencia imenso a interacção entre eles. Em geral, observa-se que o contacto de duas culturas diferentes, nomeadamente no âmbito de um processo de imigração econômica em que o grupo que comanda a economia impõe também a sua cultura ao grupo imigrado, se traduz, quase inevitavelmente, numa situação de subordinação do último face aos primeiro (Morelli, 2004). Contudo esta situação não parece ser completamente válida no caso da imigração brasileira para Portugal, uma vez que os Brasileiros têm lugar específico na sociedade portuguesa e, apesar da vulnerabilidade acrescida que está sempre associada à sua situação de imigrante, dispõem de instrumentos de defesa que tiram partido da proximidade histórica, lingüística e muitas vezes socioeconômica, relativamente aos Portugueses. $O$ processo de aculturação parece, pois modificado neste caso" (p. 155). 
Os atributos positivos presentes nas representações sociais associados à comunidade brasileira mais comuns são a simpatia e a alegria. (Lages et alli, 2006). Tais predicados são o fundamento de uma "brasilidade" na qual os portugueses tendem a enquadrar todos os brasileiros. A mestiçagem, a sensualidade, o futebol, o samba, o axé music, são elementos de características generalizantes do Brasil que possuem desdobramentos no estereótipo ao qual está sujeita a comunidade daí oriunda.

Tais características constituídas historicamente são alimentadas pelos próprios brasileiros, que, aliás, disso buscam tirar proveito. Não convém ignorar, por exemplo, a influência cultural do Brasil hoje em parte considerável dos países de língua portuguesa, na realidade, trata-se de um mercado em sentido praticamente único, sendo o Brasil um grande exportador de produtos culturais. A presença de produtos culturais brasileiros em Portugal é inconteste e relevante, seu acesso é massificado pelos meios de comunicação e pela atuação das grandes empresas. A música, as novelas, a divulgação do carnaval são exemplos evidentes. Nas palavras de Cunha (2004):

"Há cerca de 30 anos que produtos da indústria cultural e de conteúdos brasileira preenchem as grelhas das televisões portuguesas, primeiro da televisão pública (RTP1 e RTP2) depois dos dois canais privados (TVI e $S I C)$. Durante anos as grelhas destas estações - tendo como justificativa as afinidades de língua e cultura e a relação custo/qualidade - foram preenchidas por programas de humor, música, séries e telenovelas vindos do Brasil. A partir de 1994 a SIC acordou com a Rede Globo a exclusividade da exibição das telenovelas da emissora. Este acordo não significou o fim de produtos brasileiros nas outras estações, mas sim a procura de programas alternativos em outras redes brasileiras, como por exemplo a SBT" (p. 536-7).

Toma-se a música para considerações mais detalhadas. Segundo a Associação Fonográfica Portuguesa, em 2007, por exemplo, Ivete Sangalo recebeu um disco de ouro (premio oferecido aos que atingem dez mil unidades vendidas no território português). No mesmo ano, Vanessa da Mata, foi premiada com um disco de ouro e outro de platina (este último oferecido aos que atingem vinte mil unidades vendidas). Em 2008, foram Adriana Calcanhoto e Ivete Sangalo, cada uma com um disco de ouro, as artistas brasileiras galardoadas. Em 2009, Alexandre Pires e Roberto Carlos \& Caetano, receberam, cada um, um disco de ouro. 
A maior parte desses artistas brasileiros premiados em Portugal está vinculada as grandes Empresas Editoras Fonográficas, dentre as quais EMI, Sony Music, Universal. Mas, além desses artistas brasileiros premiados, muitos outros possuem seu espaço no mercado português, inclusive artistas independentes, por exemplo, a Banda Calypso ${ }^{36}$.

O sucesso atingido por esses produtos no país certamente relaciona-se com a "encarnação" por parte de alguns desses dos estereótipos e imagens criadas em Portugal referentes ao Brasil e às pessoas que aí nasceram. Isso ratifica estes juízos e contribui para sua manutenção e reprodução.

Tal fato colabora para uma sensação de aproximação dos portugueses para com os brasileiros. Em contrapartida, a recíproca é limitada, os brasileiros conhecem relativamente pouco a cultura portuguesa e muitos imigrantes chegam a Portugal completamente desinformados sobre a sociedade na qual buscarão se inserir. Ainda assim, apesar das dificuldades enfrentadas no dia-adia, encontram um espaço que the é praticamente exclusivo na sociedade receptora, a qual é relativamente aberta a eles. Para inserir-se nesse espaço, porém, o imigrante precisa corresponder às atitudes que dele se espera.

Essa relação complexa de imagens recíprocas construídas e incorporadas entre a população autóctone e os brasileiros é parte do cotidiano dos imigrantes e tem papel significativo na maneira como participam do mercado de trabalho. Muitos deles submetem-se aos estereótipos para conseguir trabalho. Machado (2007) constata de sua experiência de trabalho de campo no Porto que:

"Determinadas características são esperadas dos trabalhadores brasileiros. As principais são a alegria, simpatia e cordialidade. Acreditando que aqueles são portadores atávicos desta série de características, os empregadores portugueses procuram esses imigrantes para determinados trabalhos. É por isso que o atendimento em geral, era a grande fonte de emprego para Brasileiros na cidade do Porto. Muitos trabalhavam como garçons, vendedores de lojas, representantes de vendas, músicos. De certa forma, o Brasileiro no Porto era um entretainer. O processo que se desenrola é o de uma subordinação sistemática daquele aos estereótipos que rotulam todos os Brasileiros como pessoas alegres e simpáticas" ( $p$. 173).

\footnotetext{
${ }^{36}$ Uma dimensão da diversidade dos produtos musicais brasileiros em Portugal pode ser obtida visitando-se qualquer grande loja especializada no ramo, como as lojas da Fnac na cidade do Porto ou Lisboa. A variedade de CDs e DVDs etc. de artistas brasileiros aí presentes impressiona, fato que não se verifica em lojas homólogas em outros países europeus, como Espanha e França e Alemanha, por exemplo.
} 
Em Lisboa, Coimbra e Porto, igualmente encontrou-se, durante a pesquisa de campo, brasileiros desempenhando as funções mencionadas por Machado (2007). Dentre os trabalhadores de lojas em shopping centers e restaurantes é grande o número de brasileiro ${ }^{37}$. Foi corriqueiro em conversas com portugueses e com brasileiros que vivem ou vão freqüentemente e há algum tempo à Portugal os mesmos destacarem esse fato o associando a melhoria geral no atendimento ao público no país. O argumento é sempre o mesmo: a simpatia e cordialidade fazem dos brasileiros pessoas melhores no trato com o outro, diferentemente dos portugueses, tidos muitas vezes como tristes, fechados e, por vezes, ríspidos. As passagens abaixo demonstram essa visão de alguns imigrantes brasileiros a respeito dos portugueses:

"o português era muito mais embrutecido do que ele é hoje, mas eu só percebi isso com o tempo, ao acompanhar um pouco da história, deu pra perceber que eles realmente tinham uma razão de ser assim... Sei lá, pela imposição, o governo também era a ditatura, era tudo muito triste, então é um povo triste assim... E outra (...) teve muita muita muita miséria mesmo aqui em Portugal, né? Então, (...) cada um sabe onde aperta o seu calo, né?, onde o sapato aperta o calo. Então, depois que eu fui entender, mas no começo foi mesmo muito complicado (...) essa maneira bruta deles falarem. Nós brasileiros somos muito mais assim carinhosos, até a nossa fala é mais branda, né? (...) Depois eu fui entender perfeitamente o que se passava e gosto muito, me sinto em pé de igualdade, me sinto mesmo uma portuguesa, entendeu?,38

"Existe assim, o português ele é muito mais retraído e o brasileiro, na verdade assim o português é introspectivo, é pra dentro e o brasileiro é completamente pra fora. Eu diria que o português é muito reservado, e o brasileiro não tem reserva alguma, percebe? É essa discrepância, entendeu. Poderia ser, nem só, os dois poderiam ceder um pouquinho, ficaria um equilíbrio legal'39.

"Eu não tenho amigos portugueses... São muito fechados... Não são como a gente que brinca, fala certas coisas..., $\$ 0$

Tal como exposto acima, muitos brasileiros associam os portugueses à tristeza, à reserva, às "pessoas fechadas", e destacam isso como um dos principais elementos a diferenciá-los. Assim, nota-se certa identificação e incorporação dos brasileiros com a imagem criada pelos portugueses:

\footnotetext{
${ }^{37} \mathrm{~A}$ ida a restaurantes e shoppings foi inclusive uma estratégia bem sucedida utilizada durante o trabalho de campo para conseguir encontrar imigrantes dispostos a dar entrevistas.

${ }^{38}$ Entrevista com imigrante. Mulher. Atendente. Lisboa, pesquisa de campo, outubro de 2009.

${ }^{39}$ Entrevista com imigrante brasileira. Vendedora. Lisboa, pesquisa de campo, outubro de 2009.

${ }^{40}$ Entrevista com imigrante brasileira. Empregada doméstica. Lisboa, pesquisa de campo, outubro de 2009.
} 
consideram-se pessoas mais abertas e alegres, o que interfere na sua posição na sociedade receptora.

Machado (2007) sintetiza tais peculiaridades do espaço reservado aos brasileiros no mercado de trabalho português na expressão "mercado da alegria", o qual se constitui em uma verdadeira "prisão simbólica". Muitas vezes, incorporar esses estereótipos é um passo importante para o imigrante inserir-se no mercado de trabalho. Contudo, isso implica colaborar e reproduzir a condição de subalternidade, ao mesmo tempo em que permite subverter as lógicas precedentes. Tal movimento é contraditório e incessante, e atualiza as representações e imagens, transformando-as sem desconsiderar, porém, as existentes anteriormente.

Mas nem só de atributos positivos constituem-se os estereótipos. Aliás, os mesmos atributos ora são positivos e ora negativos, dependendo de quem os menciona e dos objetivos que possui. Um português entrevistado durante pesquisa de campo, por exemplo, afirmou que uma das contribuições trazidas pela comunidade brasileira é a alegria que caracteriza essa comunidade e a colaboração para fazer de Portugal um país multicolorido. Convém ressaltar que a alegria por ele referida diz respeito muitas vezes à maior informalidade dessas pessoas, o que é visto em Portugal por alguns como uma qualidade e por outros como um problema. Ouvimos portugueses associando a presença brasileira a barulho e "bagunça", por exemplo.

Não obstante, muitos imigrantes brasileiros compartilham de opiniões negativas sobre essa comunidade estrangeira em Portugal. O que é demonstrado pela seguinte opinião:

\footnotetext{
"a grande parcela dos brasileiros que estão em Portugal, quer dizer, estão aí com um trabalho secundário, estão na prostituição, estão aí nas obras, e, pois, a nível geral a imagem que se passa do brasileiro em Portugal hoje, é a pior possível. Eu vim numa altura, eu vim em 2000. Era uma altura que nós éramos poucos ainda e a noção que se tinha do brasileiro em Portugal era a noção daquele brasileiro que tinha formação superior, que vinha pra cá, que eram os dentistas, que eram os médicos, que eram pessoas, intelectuais que vinham pra especializar, quer dizer, nós éramos um grupo pequeno, depois a grande explosão foi 2001, 2002, hoje, segundo dados do SEF, são mais de 150.000 brasileiros que entraram de qualquer maneira e que andam por aí a fazer tudo e mais alguma coisa.

Se você verificar os dados de violência em Portugal o ano de 2007 foi o ano do pior. O nível de violência aumentou,os brasileiros e o pessoal do leste também que entrou aqui, é um pessoal também muito violento. Portanto, eu
} 
me sinto mal aqui, eu vou ser muito sincera, os brasileiros que eu lido aqui são muito poucos. Evito até de lidar com os brasileiros daqui".

Para justificar sua postura, a imigrante argumenta:

"O nível deles, e depois é... Eu não sei, eu, na minha concepção, os que vem, vem, vendem lá o que tem, as vezes um carro, pelo que vejo, as vezes um carro ou uma casa, o que for, porque acha que isso aqui é o paraíso. Vem pra cá disposto a tudo e mais alguma coisa. É o que vem. E depois muitas vezes não dá, aquilo que eles pensam que é. Que é o paraíso, etc, e começam a andar por aí a fazer coisas. Portugal não tá.., é assim, Portugal está acordado para um violência que nunca existiu, que é um país seguro, que você ainda pode andar pela rua, por o seu carro na rua, ninguém vai assaltar, os velhotes andavam tranquilos, agora não. É um tipo de violência, como o brasileiro já se acostumou que aqui é um país tão tranquilo, não é. Então, muita violência em relação ao velhotes, muita violência que se vê nas ruas que outrora não se via, assalto às malas, depois assalto à mão armada que em Portugal também não existia, e é uma violência também que os brasileiros tem aqui violenta, aquela agressividade que a gente vê no Brasil e que as vezes me assusta aqui. Eu sou brasileira, mas eu assusto com certas situações". ${ }^{41}$

Essa opinião foi expressa por uma imigrante brasileira oriunda de Belo Horizonte (MG), pós-graduada no Brasil e que estava terminando sua dissertação de mestrado em direito. Desde que terminou sua graduação em direito em Portugal, trabalha em uma universidade no país. Em seu discurso, percebe-se que a dualidade da inserção dos brasileiros no mercado de trabalho influencia as imagens recíprocas no interior desse grupo estrangeiro e entre esse e a população nativa.

O trecho acima mostra que a imigrante prefere aproximar-se dos portugueses, evitando contatos com os brasileiros que chegaram mais recentemente por considerá-los de mais baixo nível sócio-econômico, chegando a responsabilizá-los pelo aumento da violência. Certamente, sua opinião é influenciada por aquilo que percebe em sua situação, ou seja, onde está inserida, nas pessoas com as quais convive e suas nas experiências cotidianas.

Interessa destacar que a imigrante compara dois momentos distintos da imigração brasileira com duas imagens distintas, incorporando a visão que, em suas próprias palavras é a "pior possível", mas dá a entender que já foi diferente, sugerindo certo respeito da sociedade receptora pelo fato de os

\footnotetext{
${ }^{41}$ Entrevista com imigrante. Mulher. Advogada e psicóloga. Lisboa, pesquisa de campo, outubro de 2009.
} 
imigrantes brasileiros possuírem anteriormente elevada formação. Embora expresse a opinião pessoal da imigrante, é conveniente perceber que é plausível a transformação das representações e imagens à medida que esse fluxo migratório altera-se qualitativamente.

Dentre as qualificações negativas dadas pelos portugueses à comunidade brasileira estão atualmente: a malandragem, a bagunça e barulho, a exacerbação da sensualidade à sexualidade e vulgaridade. A malandragem, no sentido positivo, amiúde traz em si a idéia de flexibilidade, de facilidade de adaptação associada à comunidade brasileira. Negativamente, refere-se a certa "falta de caráter" dos brasileiros.

Uma portuguesa, proprietária de pensão para estudantes em Coimbra, por exemplo, mencionou em conversa esse "defeito" brasileiro. Segundo ela, todo o ano, quando da chegada dos novos alunos ela costuma avisar às estudantes estrangeiras que tenham cuidado com os rapazes brasileiros, pois eles são muito sedutores e educados, mas muito malandros. Além disso, a mesma Senhora destacou que, desde que tem a pensão, repetidas vezes teve que chamar atenção de brasileiros que lá moravam por conta das "farras", "barulho" e "bagunça" que faziam. Amenizando o discurso, afirmou também que no geral eram pessoas esforçadas e trabalhadoras. Essa opinião era baseada no fato de que dentre os brasileiros que moram na casa, a grande maioria trabalha para se manter em Portugal, ao contrário de muitos estrangeiros vindos da Europa, por exemplo.

Mas é freqüente a associação de brasileiros à preguiça e à malandragem. Lages (2006) constata que apenas 30\% dos portugueses consideram os brasileiros bons profissionais, competentes e cumpridores, enquanto somente $26 \%$ vêem esse grupo estrangeiro como pessoas sérias e honestas.

A preguiça e a malandragem são imputados principalmente aos brasileiros homens pela sociedade portuguesa. Embora a sensualidade também seja a eles associada, é, sobretudo, com relação às mulheres que adquire uma conotação mais exagerada e negativa. Por isso, quando a sociedade portuguesa associa os principais grupos imigrantes a algum desvio social que the seria próprio, nomeadamente, drogas, prostituição e crime organizado, elege a prostituição feminina como prática característica da 
comunidade brasileira (Lages et alli, 2006). A respeito dos estereótipos sobre brasileiros e brasileiras em Portugal, Padilla (2007) afirma:

"Embora se pense que os Brasileiros em geral gostam de festa e estão sempre bem dispostos (...) os homens brasileiros são considerados preguiçosos e malandros, e as mulheres calorosas, exuberantes e fáceis. Entre esta imagem da brasileira calorosa e exuberante e a da prostituta vai só um passo, sendo esta analogia reforçada pelas notícias permanentes que os media transmitem" (p. 125).

Não é possível dissociar essa imagem da repercussão que teve o caso de Bragança na mídia nacional e internacional. Em outubro de 2003 a capa da edição européia da revista estadounidense Time anunciava Bragança como o "novo distrito europeu da luz vermelha" (foto 3 ).

\section{Foto 3: Bragança na capa da revista Time}

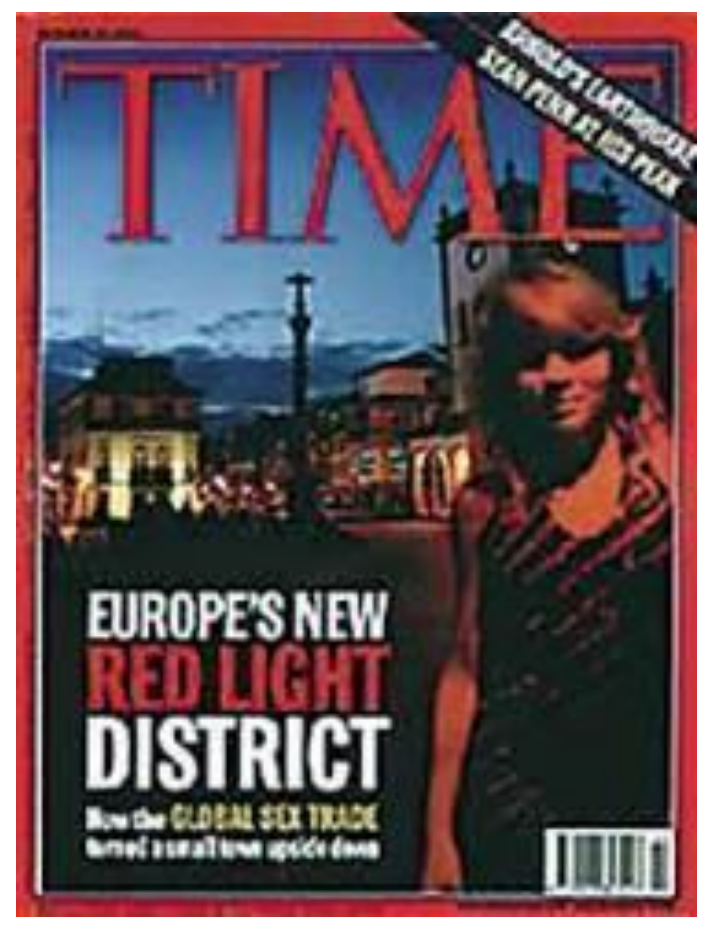

Em 14 de outubro de 2003 a revista Time publica reportagem que destaca a participação de Portugal no mercado global do sexo. A ênfase é dada ao distrito de Bragança, cuja presença de mulheres brasileiras ligadas à prostituição é relevante.

Amplamente comentada pelos meios de comunicação portugueses, a reportagem é ainda hoje bastante recordada e trouxe impactos relevantes às mulheres imigrantes brasileiras no país de modo geral.

Foto: Revista Time.

Local: Europa

Data: 14 de outubro, 2003.

A reportagem, assinada por Amanda Ripley, denunciava a presença de aproximadamente trezentas prostitutas brasileiras que atuavam nas casas de alterne $^{42}$ da área de Bragança. Esse distrito, localizado na região de Trás-os-

\footnotetext{
${ }^{42}$ As chamadas casas ou bares de alterne são casas noturnas em que mulheres trabalham fazendo companhia para homens e incentiva-os a pagar bebidas. Nem sempre as casas de alterne estão associadas à prostituição, mas todas
} 
Montes, nordeste de Portugal, está em uma área de pouco dinamismo econômico no país.

A presença de prostitutas em Bragança começa a tornar-se notável a partir de 2001. A proximidade da área com a Espanha e a facilidade com a língua são apontadas como fatores que fizeram ganhar destaque a presença de mulheres brasileiras nessa atividade. A partir de então, abre-se na cidade de cerca de 27.600 habitantes, cerca de sete boates, processo que é acompanhado por outras cidades da região.

Segundo a reportagem a presença das prostitutas trouxe maior dinamismo econômico a alguns setores, nomeadamente, os salões de beleza, os taxis e os restaurantes. Mas também trouxe resistência das mulheres portuguesas, as quais autodenominadas "mães de Bragança" destacavam que as brasileiras levavam a destruição de casamentos e de lares. Em maio de 2003, as "mães de Bragança" produziram um manifesto que foi entregue à polícia local exigindo providências quanto à prostituição.

As diversas denúncias levaram a três processos judiciais, várias condenações e fechamento de algumas casas de alterne. Segundo dados do SEF citados pelo periódico Expresso (2008), 60\% das brasileiras engajadas na atividade conseguiram se legalizar, enquanto o restante foi deportado ou continua em Portugal de modo irregular.

Recorda-se que em Portugal a prostituição não é uma atividade proibida, mas seu incentivo é ilegal. Dessa maneira, as prostitutas estrangeiras não podem ser deportadas pelo exercício dessa atividade, mas sim pela situação de seus documentos no país, ou seja, se aí estiverem de modo irregular.

Apesar da grande repercussão do caso e dos fatos dele decorrente, a prostituição ainda é uma atividade presente em Bragança, embora tenha mudado em alguns aspectos: há novas territorialidades, ao invés de uma concentração ao redor do castelo de Bragança, mais atualmente se destaca a estação rodoviária; ao invés das casas de alterne, crescem as prostitutas que, por conta própria, atendem aos clientes em apartamentos alugados (Jornal Expresso, 2008).

elas exploram o sexo como forma de obter mais lucro, um exemplo é a apresentação de shows eróticos. Por isso, embora não sejam sinônimos de prostíbulos, pode-se considerá-las como participantes do mercado do sexo. São bastante difundidas em Portugal, constituindo um tipo de atividade muito bem sucedida quanto ao retorno financeiro. 
Em jornais portugueses publicados diariamente há inúmeros anúncios de mulheres prostitutas, dentre as quais é notável a participação de estrangeiras. Em alguns deles as mulheres explicitam sua nacionalidade, como cabo-verdianas, por exemplo. No caso das brasileiras, isso muitas vezes não ocorre, mas há outras maneiras de identificar sua origem. A principal delas, 0 modo de expressar-se no anúncio, utilizando-se palavras pouco comuns no vocabulário da sociedade portuguesa.

Além disso, de modo mais geral, ainda é considerável a atenção dos meios de comunicação à prostituição de mulheres brasileiras no país. A conseqüência reflete aquilo afirmado por Padilla (2007):

"Frequentemente, vemos ou ouvimos notícias sobre a quantidade de prostitutas brasileiras detidas em rusgas, mesmo que sejam ou não alvos de tráfico ilegal de pessoas, e a sociedade fica com a ideia da proeminente participação das brasileiras na prostituição nacional, o que acaba por reforçar ainda mais a relação entre essas e a indústria do sexo" (p. 125).

Em pesquisa de campo o fenômeno da prostituição de mulheres brasileiras foi mencionado por inúmeras pessoas, tanto portuguesas como brasileiras. É comum encontrar imigrantes que compartilham a ideia de que se trata de uma característica específica dessa comunidade estrangeira com a sociedade receptora, o que acaba por reforçá-la. Isso é exemplificado no discurso a seguir:

"Não... eu nunca enfrentei situação discriminatória... Pelo menos assim o homem não... Mas a grande provocação do português para um brasileiro é a prostituição da mulher brasileira...

Essa prostituição é real... É real... Quem fez a fama da brasileira dentro e fora do país é elas mesmo... Isso é a realidade... Muitas e muitas brasileiras durante a semana elas chamam Daiane, no final de semana ela é Adriana, ou qualquer outra coisa, porque aí ela volta pra casa que ali ela diz que é família. A grande realidade é essa... Hoje, eu digo pra você que se encontra muitas que não é dessa área, você encontra algumas, mas a grande maioria, infelizmente, é isso mesmo..."

Muitas mulheres brasileiras defrontam-se constantemente em Portugal com esse estereótipo que é alimentado por alguns fatos amplamente divulgados pelos meios de comunicação. Pelas conseqüências relevantes que possui o tema da prostituição e de modo mais amplo da inserção laboral de

\footnotetext{
${ }^{43}$ Entrevista com imigrante. Homem. Trabalhador na construção civil. Lisboa, pesquisa de campo, outubro de 2009
} 
brasileiras no mercado do sexo, convém observar o fenômeno mais atentamente.

\subsubsection{Brasileiras no mercado do sexo em Portugal}

A experiência empírica tornou impossível não considerar aqui o mercado do sexo. Contudo, houve grande dificuldade de atingir esse universo, só foi possível de maneira indireta, entrevistando a psicóloga do Serviço Jesuíta de Refugiados - JRS, da Unidade Habitacional de Santo António - UHSA, pertencente ao SEF, localizada na cidade do Porto.

Nessa Unidade ficam temporariamente as pessoas que por determinação judicial aguardam detentas os trâmites burocráticos que envolvem o processo de deportação. Quanto à comunidade brasileira, embora não existam dados oficiais sobre isso, a maior parte dos casos de pessoas obrigadas a retornar ao país de origem e que aí são detidas, segundo a experiência cotidiana da psicóloga Ihe permite inferir, são mulheres encontradas, sobretudo em casas de alterne e em situação de irregularidade.

Segundo a psicóloga, a maior parte dos casos que atende diz respeito a mulheres que já eram prostitutas no Brasil e que vão para Portugal sabendo que se engajarão no mercado do sexo. Dentre as justificativas que já ouviu, a psicóloga diz que a mais comum é o volume de dinheiro conseguido nesse tipo de atividade.

Dados da Direção Central de Investigação, Pesquisa e Análise de Informação (DCIPAI) do SEF sobre os inquéritos abertos referentes a crimes de lenocínio e tráfico de mulheres confirmam estas percepções da psicóloga. Segundo o órgão, o perfil caracteriza-se como:

"Mulher brasileira com idade compreendida entre os 22 e os 30 anos, solteira, com nível médio de instrução (idêntico ao $12^{\circ}$ ano de escolaridade em Portugal e emprego no sector terciário no país de origem, oriunda maioritariamente do estado de Goiás, viajando pelos seus próprios meios e vontade para Portugal. (...)

O motivo da viagem é primordialmente a melhoria das condições de vida ou a debilitada situação econômica em que se encontram no país de origem. Portugal torna-se destino por excelência de mulheres brasileiras, que, devido à sua "instrução média" preferem um país em que falem língua similar, eximindo-se da necessidade de aprendizagem de uma outra.

Quer sejam familiares, amigo ou agências de viagens, por vezes as mulheres que se encaixam neste perfil são aconselhadas a não viajar 
directamente para Portugal, onde o controlo de entrada é, por vezes, mais rigoroso, sendo direccionadas para Espanha e França, onde a barreira lingüística impede uma verificação mais pormenorizada relativamente aos motivos/intenções da viagem ou condições de estada em Portugal. (...)

Estas mulheres viajam, na sua maioria, sozinhas, tendo algumas à sua espera e, em Portugal, familiares ou "amigas"/conhecidas, que mais tarde as direccionam para os estabelecimentos de diversão nocturna.

Mulheres que já se encontram inseridas no ramo contactam, pessoalmente ou não, amigas ou conhecidas suas, por vezes mesmo familiares, que conhecendo a situação financeira destas em Portugal querem, também, melhorar a sua condição. São então aliciadas a viajar com a promessa de um bom emprego, boas condições, melhor vida. A maior parte destas mulheres não tem um conhecimento concreto sobre essa oferta de trabalho nem sobre as condições requeridas para o seu desempenho. No entanto, pra grande parte, o trabalho prometido não é diferente daquele que acabam por encontrar em Portugal.

Normalmente, as mulheres brasileiras conseguem ultrapassar a situação de endividamento para pagar a viagem ao fim de algum tempo, havendo casos em que essa dívida é assumida perante uma instituição bancária ou a própria família.

Muitas mulheres não pretendem continuar a exercer esta actividade em Portugal. No entanto, apenas uma parte menor deseja voltar ao Brasil o mais rapidamente possível. O mesmo sucede relativamente à possibilidade de receberem apoio ou serem até colocadas numa "casa segura", onde podem receber apoio psicológico, médico e social, o que é normalmente recusado. Já sobre a questão de poderem ser consideradas vítimas de tráfico de seres humanos, usualmente, as mulheres brasileiras afirmam que não se encontram nessas condição.

Outro factor relevante, é de haver um número relativamente significativo de mulheres brasileiras que se encontra em Portugal numa situação de permanência irregular em território nacional, sem contrato de trabalho, sem descontos para a segurança social e finanças e sem possibilidade de legalização" (SANTOS, 2007: p. 93-94).

Fica evidente, em vista do exposto, que majoritariamente as mulheres brasileiras ligadas ao mercado do sexo em Portugal não são vítimas de crime de tráfico de pessoas. Isso quer dizer que grande parte delas sabe o que vai fazer no país receptor, o que leva à conclusão de que é dona de seu próprio projeto migratório. Apesar disso, muitas mulheres desconhecem as condições objetivas em que isso irá ocorrer. Desse modo, comumente deparam-se com a sujeição a circunstâncias vinculadas diretamente ou não à exploração sexual e violência. Assim, uma proporção considerável passa a ter a vida controlada por meio de ameaças, força, coerção, abuso de sua vulnerabilidade ou de poder, dentre outras formas cerceadoras de seus direitos e liberdades (UNODC, 2006).

Exploração sexual e violência são também a condição geral da parcela dessas mulheres imigrantes que são vítimas de tráfico. O diretor do JRS, 
durante entrevista em Lisboa, mencionou o caso de uma brasileira vítima de uma rede de tráfico que conseguiu fugir e procurou o JRS pedindo ajuda. Atualmente, essa mulher é imigrante regularizada em Portugal e colabora nos serviços prestados pela instituição.

O caso evidencia, ao contrário do que é difundido no senso comum, que o tráfico de mulheres brasileiras para Portugal não é irrisório. A dificuldade, porém, é quantificá-lo. Conforme se pode concluir do que foi citado anteriormente, um dos problemas advém de que as redes de tráfico confundem-se com redes sociais: muitas vezes elas são compostas por pessoas que possuem relações de amizade ou de parentesco.

Soma-se a isso que, na Europa, são freqüentes casos em que mulheres vítimas tornam-se traficantes, muitas vezes sem ter consciência do fato, como demonstra a UNODC $(2006,2010)$. Os dados nos permitem deduzir que Portugal segue essa característica do continente: no período de 2003 a 2006, a proporção de mulheres entre os condenados pelo crime de tráfico de pessoas foi de $23 \%$, enquanto a mesma proporção para todos os demais delitos no mesmo período foi de $8 \%$.

Segundo a Polícia Judiciária de Portugal, nos anos de 2004 a 2006, foram registradas 189 investigações pelo crime de tráfico de mulheres para fins de exploração sexual no país. Dos inquéritos, verificou-se que $46 \%$ das vítimas são oriundas do Brasil, enquanto $51 \%$ dos arguidos e suspeitos são portugueses, dos quais a maioria são homens, 59\% e 73\% respectivamente (Santos, 2007).

Essas redes ilegais de tráfico de pessoas para fins de exploração sexual, muitas delas coercitivas, constituem $79 \%$ dos casos de tráfico de pessoas registrados em todo globo, o qual é um dos negócios ilícitos mais lucrativos, atrás apenas do tráfico de armas e de drogas. Por conseguinte, é uma fonte importante de rendimentos do crime organizado que atua de maneira nacional e/ou transnacional (UNODC, 2006; UNFPA, 2007).

De modo geral, angariam-se pessoas no país de origem e se insere as mesmas em bares, boates etc. voltados à prostituição e/ou alterne no país receptor. Suas ações ultrapassam as fronteiras territoriais e desafiam os Estados nacionais. A figura a seguir evidencia a inserção dos países nas redes de tráfico que se dirigem para a Europa Ocidental. 
Figura 9: Mulheres detectadas como vítimas de tráfico, segundo país de origem, para fins de exploração sexual na Europa Ocidental, situação no período de 2005 a 2007

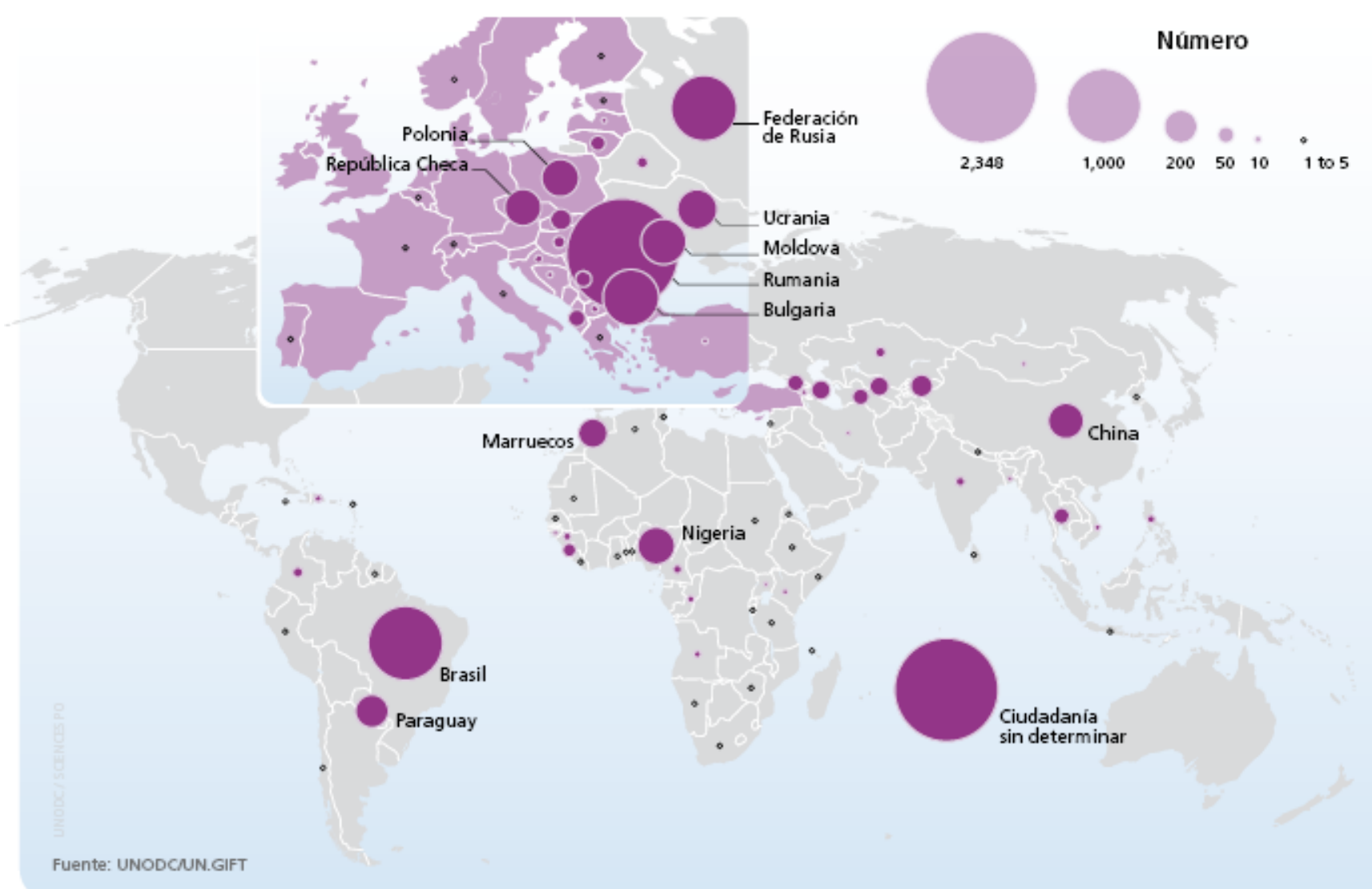

Fonte: UNODC. Trata de personas hacia Europa con fines de explotación sexual. Viena, Áustria: United Nations Office on Drugs and Crime, 2010, p. 2.

Pode-se notar na figura 9 que na América do Sul, o Brasil tem amplo destaque como origem das mulheres traficadas com destino à Europa. Tal fato é confirmado pela constatação de que as vítimas provenientes do Cone Sul vão, principalmente, para Espanha, Itália, Portugal, França, Países Baixos, Alemanha, Áustria e Suiça; dentre os quais sobressaem alguns importantes receptores de fluxos migratórios do Brasil. Ressalta-se que o percentual de vítimas brasileiras é crescente, o que se explica, dentre outros fatores: 
“(...)pelo baixo custo operacional, pela existência de boas redes de comunicação, pelas facilidades de ingresso em vários países sem a formalidade de visto consular, pela tradição hospitaleira com turistas e pela miscigenação racial” (OIT, 2006: p. 19).

O perfil traçado para o conjunto de vítimas de tráfico de pessoas para fins de exploração sexual no Brasil é o seguinte:

“(...)o tráfico é, predominantemente, de mulheres e adolescentes, afrodescendentes, com idade entre 15 e 25 anos.

(As) mulheres são oriundas de classes populares, apresentam baixa escolaridade, habitam em espaços urbanos periféricos com carência de saneamento, transporte (dentre outros bens sociais comunitários), moram com algum familiar, têm filhos e exercem atividades laborais de baixa exigência. Muitas já tiveram um passado na prostituição.

Estas mulheres inserem-se em atividades laborais relativas ao ramos da prestação de serviços domésticos (arrumadeira, empregada doméstica, cozinheira, zeladora) e do comércio (auxiliar de serviços gerais, garçonete, balconista de supermercado, atendente de loja de roupas, vendedoras de títulos, etc.), funções desprestigiadas ou mesmo subalternas. Funções estas, mal remuneradas, sem carteira assinada, sem garantia de direitos, de alta rotatividade e que envolvem uma prolongada e desgastante jornada diária, estabelecendo uma rotina desmotivadora e desprovida de possibilidades de ascensão e melhoria.

As mulheres e as adolescentes em situação de tráfico para fins sexuais geralmente já sofreram algum tipo de violência intrafamiliar (abuso sexual, estupro, sedução, atentado ao pudor, corrupção de menores, abandono, negligência, maus-tratos, dentre outros) e extrafamiliar (os mesmos e outros tipos de violência intrafamiliar, em escolas, abrigos, em redes de exploração sexual e em outras relações)" (Pestraf op.cit. OIT, 2006: p. 25).

Percebe-se, diante do exposto, que são principalmente mulheres com um perfil de grande vulnerabilidade sócio-econômica, que acabam por cair em rotas domésticas e internacionais do tráfico de pessoas. Dentre essas últimas, Portugal aparece como o quinto principal destino: são cerca de oito rotas cujos pontos de origem partem de Pernambuco, Maranhão, Rio Grande do Sul, São Paulo, Rio de Janeiro, Goiás, Minas Gerais, Mato Grosso do Sul (Dias, 2005).

Sabe-se, por exemplo, que em Bragança existia uma agência que recrutava mulheres a partir do Rio de Janeiro. Contudo, a maioria delas era de Minas Gerais, Goiás e Goiânia (Expresso, 2008). Isso denuncia a existência de uma capilaridade dessa rede em ambos os países considerados. No Brasil, o fluxo não parte do Rio de Janeiro, mas inclui áreas mais interiorizadas do país. Em Portugal, por sua vez, a partir de Bragança, muitas dessas redes ramificam-se para outras cidades do território português e também para a Espanha. 
Como já exposto, é comum que a viagem não seja feita diretamente a Portugal, pois prefere-se outros aeroportos europeus em virtude, principalmente da língua. Mais uma vez, essa aparece como um fator importante. Portugal é eleito país de destino justamente pela ampliação da esfera de ação das pessoas oriundas do Brasil, em contrapartida, aí essas pessoas, estão sujeitas a maior controle. Dessa forma, a preferência da entrada pela Espanha ou França, dentre outros, é uma estratégia para se burlar possíveis fiscalizações, as quais se tornam mais difíceis se a língua não é a mesma.

O sucesso de tais estratégias é perceptível quando as estatísticas mostram que a maior parte das estrangeiras envolvidas no mercado do sexo em Portugal é brasileira. Segundo a DCIPAl, a proporção dessas, nas mulheres encontradas em situação de prostituição e/ou alterne em suas investigações e fiscalizações, realizadas no período de 2003 a 2007, é de $80 \%$ (gráfico 16). Em termos absolutos, isso se refere a 2441 mulheres.

Gráfico 16: Principais áreas de origem das mulheres identificadas em ações do SEF em situação de alterne e/ou prostituição no período de 2003 a 2007

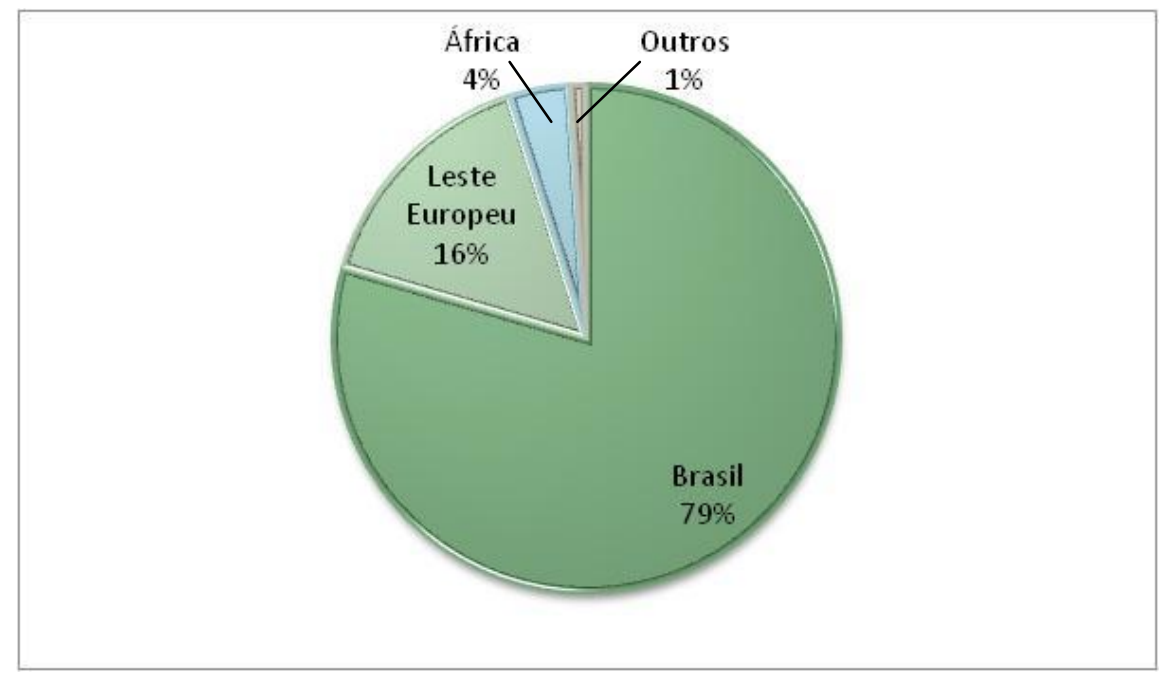

Fonte: SANTOS, Boaventura de Sousa. (et alli). Tráfico de Mulheres em Portugal para fins de exploração sexual. Coimbra: CES \& CAIM, 2007, p. 92.

Organização: Aline Lima Santos.

Essa informação verificada ano a ano (gráfico 17), no período de 2003 a 2007, mostra queda no número de brasileiras identificadas em ações do SEF, 
mas isso não foi acompanhado de queda em termos relativos. Em 2004, por exemplo, as brasileiras representavam cerca de $77 \%$ das mulheres identificadas, já em 2006, atingiam 86\%.

\section{Gráfico 17: Mulheres identificadas em ações do SEF em situação de alterne e/ou prostituição no período de 2003 a 2007}

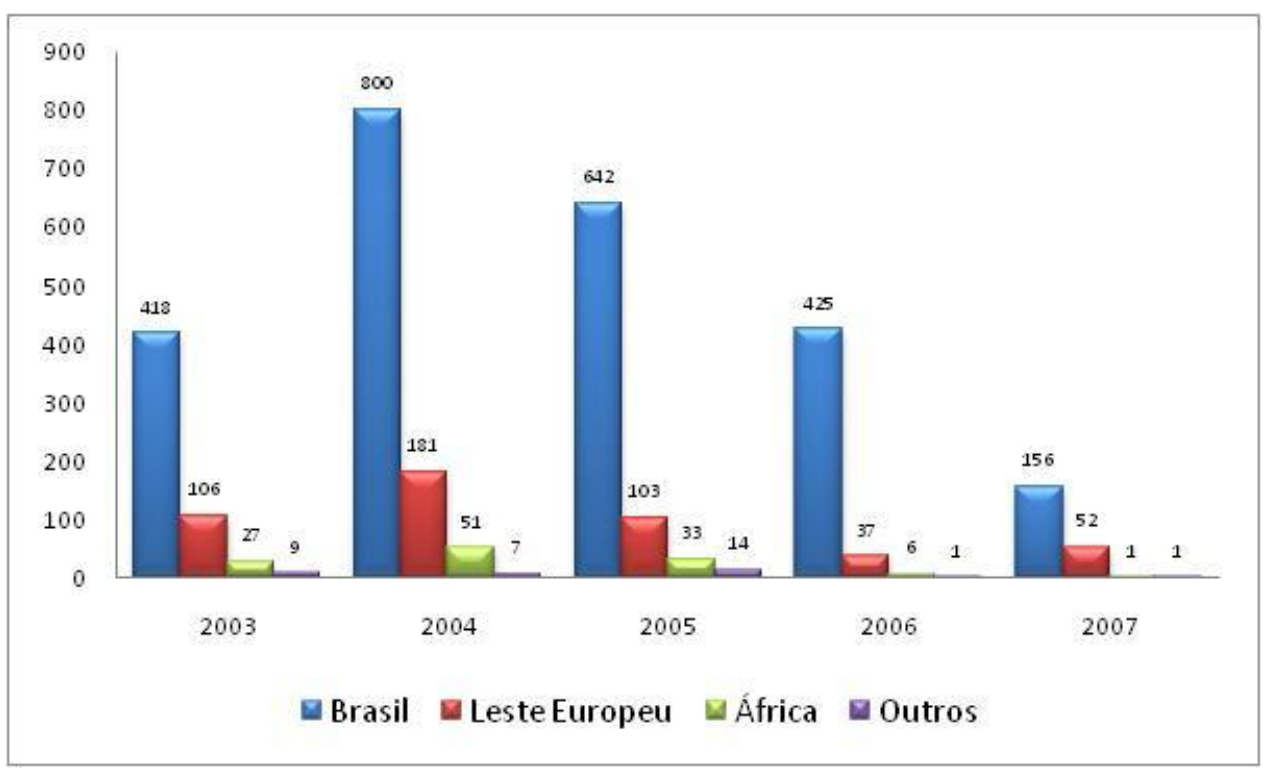

Fonte: SANTOS, Boaventura de Sousa. (et alli). Tráfico de Mulheres em Portugal para fins de exploração sexual. Coimbra: CES \& CAIM, 2007, p. 92.

Organização: Aline Lima Santos.

É apropriado lembrar que esses dados dizem respeito às fiscalizações e inquéritos, assim não contempla satisfatoriamente o universo sobre o qual se debruça; porém deles oferece alguma aproximação. A queda geral do número de mulheres identificadas pode resultar da diminuição das ações de fiscalização, por exemplo.

De qualquer maneira, sabe-se que é crescente a participação das mulheres estrangeiras na prostituição e/ou alterne em Portugal. As diferentes nacionalidades são colocadas em "locus" específicos: as brasileiras são mais encontradas nas casas de alterne, bem como as mulheres provenientes do leste europeu, as quais, porém, estão mais ligadas à prostituição de luxo. As africanas, por sua vez, são colocadas nas ruas, onde é comum, também, encontrar romenas. Isso pode variar dependendo da região do país. No Porto, por exemplo, as brasileiras tem presença marcante na prostituição de rua (Santos et alli, 2007). 
Isso ocorre paralelamente a uma intensa circulação no interior do território português. As rotas internas envolvem grandes centros urbanos, grandes rodovias e zonas fronteiriças. A participação brasileira nessas rotas concentra-se na região norte do país, segundo entrevistado por Santos et alli (2007) :

“(...) a zona Norte do país tem uma característica muito própria que não se vê no resto do país que é o intercâmbio sobretudo de duas nacionalidades fortes: a brasileira dos dois lados e a colombiana do outro lado espanhol, que vem muitas vezes ao lado português. O Norte gosta muito não só da brasileira, mas da sul-americana. E é muito freqüente ver (...) como as brasileiras circulam para lá e para cá. (...) É muito curioso, porque no resto do país não se vê" (p. 114).

A rotatividade e circulação dessas mulheres dizem respeito a uma peculiaridade do mercado do sexo: seus clientes estão sempre em busca de novidades, novas mulheres, com as mais diversas características físicas. Todavia, é curioso o fato de que as brasileiras são menos sujeitas a essa circulação do que o que se verifica em outras nacionalidades (Santos et alli, 2007).

A presença significativa das mulheres brasileiras no segmento do mercado do sexo decorre, como ressaltam Peixoto \& Figueiredo (2007), de sua desregulamentação, a qual o torna "propício à incorporação de trabalho estrangeiro" (p. 107), bem como outros segmentos do mercado de trabalho pouco ou nada exigentes de qualificação e altamente vulneráveis e inseguros. Os autores reiteram: "os estereótipos associados aos Brasileiros, em geral, aliaram-se aos que se aplicam às mulheres brasileiras em particular, para reforçar a presença brasileira no sector" (p. 107).

Além disso, a ideia bastante difundida de que a maioria está engajada nessa atividade laboral por vontade individual deixa de considerar os demais elementos que compõem a realidade, já que as escolhas individuais se enquadram em situações geográficas específicas. Como conseqüência, amplia-se a vulnerabilidade dessa parcela de imigrantes brasileiros em Portugal, pois:

"ao assumirem-se como uma das nacionalidades predominantes no "mercado do sexo" em Portugal, muitas mulheres brasileiras ficam ligadas a processos de exclusão social e mundos de precariedade que naturalmente poderão, em determinado momento, configurar situações de tráfico sexual. 
Nesse sentido, 0 facto de a prostituição das brasileiras ser esmagadoramente percebida como uma opção "laboral migratória" pode levar a que passem despercebidas situações de exploração e tráfico" (Santos et alli, 2007: p. 341).

Vítimas ou não de redes de tráfico de pessoas para fins de exploração sexual, essas mulheres brasileiras prostitutas em Portugal participam de um mercado global do sexo, caracterizado por ser secreto e ilegal, isto é, "underground". Esse mercado corresponde a negócios que, estima-se, totalizam cerca de 50 bilhões de dólares no mundo, viola os direitos humanos e desafia os Estados nacionais de origem e de destino (UNDOC, 2010).

\subsection{Imigrantes brasileiros e desafios enfrentados}

As transformações presentes na paisagem denunciam os processos espaciais, entre eles as migrações. Novos objetos materiais adicionados aos territórios e novos usos dados às velhas formas revelam a presença brasileira no mercado de trabalho português e, mais do que isso, a sua presença na sociedade, no território do país.

São as igrejas evangélicas brasileiras, os salões de beleza, as lojas que vendem produtos do Brasil, etc, como é possível verificar nas fotos a seguir. Essa materialidade demonstra como os brasileiros estão influenciando 0 território português em diferentes aspectos, desde a religião até a estética.

Mais do que mera materialidade, portanto, as mutações na paisagem revelam novas relações. Essas envolvem brasileiros e portugueses, brasileiros e demais grupos estrangeiros e brasileiros entre si. Trata-se de problematizar, portanto, quais os novos desafios inerentes às relações estabelecidas para os imigrantes brasileiros e como os mesmos lidam com tais desafios. 


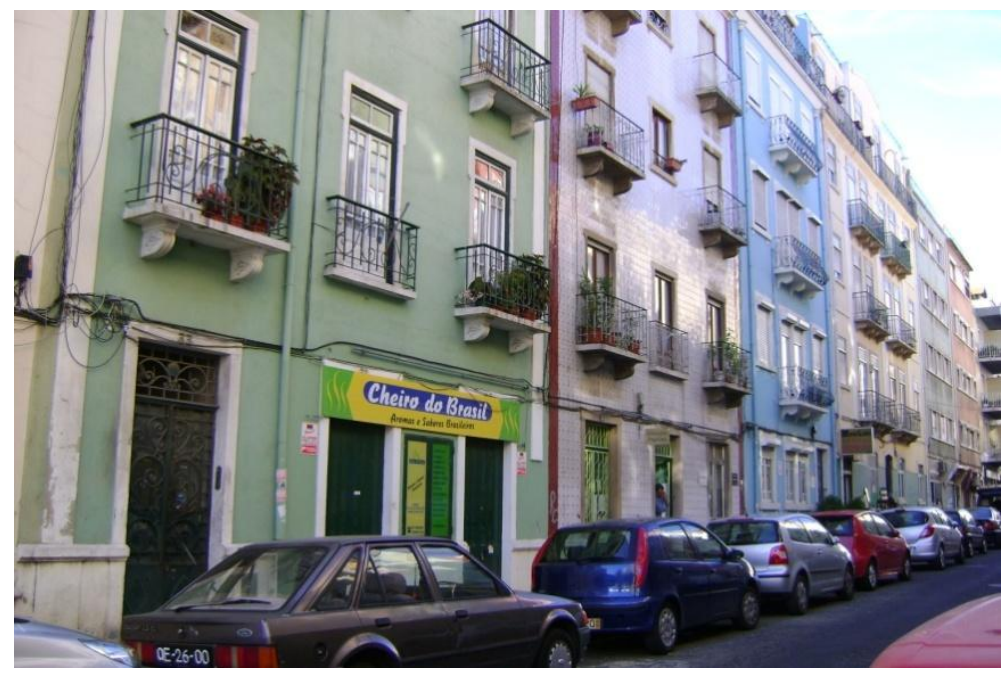

Em destaque na foto, placa indicando loja que vende produtos brasileiros. $\mathrm{Na}$ "Cheiro do Brasil", segundo a publicidade, encontra-se "aromas e sabores brasileiros", para se "matar a saudade". Curiosamente, muitas desses tipos de comércio, embora ostentem a bandeira brasileira, pertencem a portugueses que já migraram para o Brasil

Foto: Aline Lima Santos

Local: Lisboa

Data: setembro de 2009

\section{Foto 5: Centro de estética brasileiro}

Há muitas mulheres brasileiras exercendo atividades ligadas à estética em Portugal. São elas depiladoras, cabeleireiras, manicures, massagistas, etc. Algumas conseguem montar seu próprio salão de beleza, caso da foto ao lado, outras atendem as clientes em suas residências, como é o caso de uma imigrante entrevistada em trabalho de campo. $\mathrm{Na}$ ocasião da entrevista, houve contato com uma cliente portuguesa que afirmou "as brasileiras deixam as portuguesas mais bonitas. Elas gostam mesmo de estar bonitas, como se vê nas novelas, não é? Pronto, então dá vontade de se cuidar também".

Foto: Aline Lima Santos

Local: Lisboa

Data: setembro de 2009

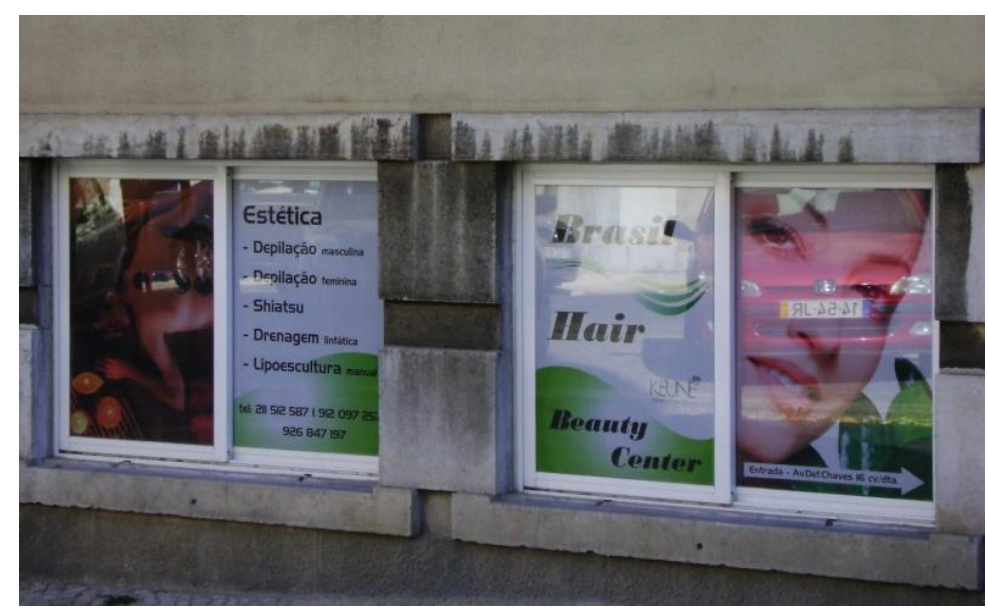


Foto 6: Igrejas evangélicas brasileiras

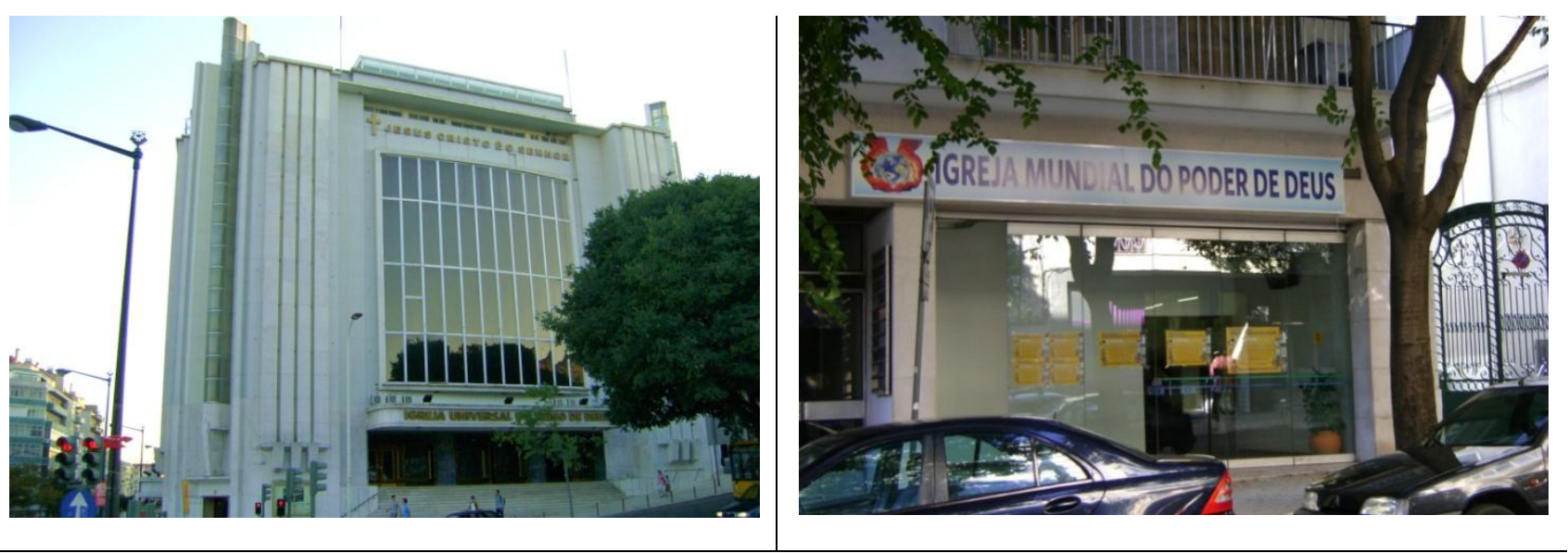

As igrejas evangélicas brasileiras também estão presentes em Portugal. A imponência dos templos não passa despercebida, como é o caso da Igreja Universal do Reino de Deus (foto da esquerda) e da Igreja Mundial do Poder de Deus (foto da direita). Mas além de igrejas pentecostais, há as mais tradicionais, como a Igreja Batista, por exemplo, cuja origem é nos Estados Unidos, mas é difundida pelo Brasil e daí atua hoje em território português. A maior parte de seus freqüentadores são pessoas oriundas do Brasil, bem como os pastores, músicos, etc., mas nos cultos também se vê portugueses e demais estrangeiros.

Fotos: Aline Lima Santos

Local: Lisboa

Data: outubro de 2009

A possibilidade de se encontrar em Portugal diferentes coisas que remetem ao Brasil é um alentador aos imigrantes aí presentes. Isso é explícito na afirmação a seguir:

"A dificuldade que eu tive era a saudade do Brasil, da família, de estar com os amigos, da comida. Porque agora, já não... agora tudo o que tem no Brasil, aqui tem. Mas quando eu cheguei aqui, não existia nada do Brasil. A novela que passava aqui era "O Casarão", que no Brasil já tinha terminado a muito tempo. Então eu vivi um tempo assim... difícil... só nesse aspecto..."44.

Este imigrante brasileiro chegou a Portugal em 1982. Trata-se, portanto, de um representante da primeira onda migratória de brasileiros no país. Como ele destacou, nessa fase, "não existia nada do Brasil", o que somado às saudades dos familiares e amigos tornou sua adaptação mais difícil. Com o passar do tempo, à medida que foi aumentando a presença brasileira,

\footnotetext{
${ }^{44}$ Entrevista com imigrante. Homem. Ex-jogador de futebol. Porto, pesquisa de campo, novembro de 2009.
} 
naturalmente esta dificuldade passa a diminuir seu peso, deixando de ter relevância significativa entre os imigrantes da segunda onda.

Essa, porém, enfrenta outros tipos de desafios, dentre os quais o acesso à moradia. Sobre isso, uma imigrante brasileira qualificada, que chegou a Portugal em 2000, chama atenção ao desemprego que atualmente se verifica no país, bem como a piora de condições e salários, então:

"muitos vão viver num apartamento com 10, 15 brasileiros juntos, aí chega um salário, que às vezes na cabeça dele 450 Euros é muito dinheiro lá no Brasil, isto aqui, se for arrendar um quarto paga 200, vai comer, porque ele tem que comer, vai gastar uns 150 , vai sobrar então muito pouco" ${ }^{, 45}$.

Esse tipo de situação é comum entre os migrantes recém chegados. De modo geral, a casa é de um português, que a aluga para um brasileiro, o qual aluga os quartos para outros brasileiros. De modo geral, os quartos são divididos entre quatro, cinco pessoas, em casas que chegam a acomodar 14 pessoas, como o testemunho a seguir:

"Aqui já tiveram quatorze, hoje são dez, não, são oito pessoas, todos brasileiros. (...) $O$ apartamento é de um português, um brasileiro aluga $O$ apartamento e aluga os quartos para terceiros; ele é o responsável por todo o apartamento sendo que ele vai alugando os quartos, ou seja, o apartamento custa numa faixa de setecentos euros, então ele aluga cada quarto com duas pessoas, cada uma paga cento e cinqüenta euros, ou seja, cada quarto é, digamos aí trezentos euros, então são quatro quartos, então são mil e duzentos euros, assim paga a despesa e a sobra fica pra ele.

Isso é uma prática muito comum. Aqui em Portugal é muito comum a pessoa alugar um apartamento que tenha mais... Às vezes ele é casado e ele aluga um apartamento que tenha três quartos para alugar para mais dois casais. Isso é normal aqui, é uma prática normal. Há alguns que não gostam disso, há alguns que alugam uma casa pra si próprio, mas tem muitos que fazem isso pra dividir as despesas, principalmente os que querem voltar pro Brasil fazem isso"46.

A casa em que se ficou hospedada em Lisboa, por exemplo, foi alugada por um casal de brasileiros, por setecentos euros; possuía três quartos, os quais o casal alugava por duzentos, duzentos e cinqüenta e trezentos euros, sendo o mais barato, menor. Assim, conseguiam "economizar" dinheiro no aluguel. Esse casal já havia passado pela experiência de morar em um

\footnotetext{
${ }^{45}$ Entrevista com imigrante. Mulher. Advogada. Lisboa, pesquisa de campo, outubro de 2009.

${ }^{46}$ Entrevista com imigrante. Homem. Assistente de cuidados com idosos. Lisboa, pesquisa de campo, setembro de 2009.
} 
apartamento arrendado por outro brasileiro, e referiam-se à experiência como muito ruim. Destacam que agora tinham a liberdade de escolher com quem morar, visto que eram os responsáveis pelo aluguel.

Esse tipo de estratégia é comum entre os imigrantes brasileiros recém chegados a Portugal. Porém, a tendência é de que os imigrantes consigam, depois de um tempo, um trabalho melhor. Com remunerações mais elevadas, torna-se possível alugar sua própria moradia para viver só ou para locar os outros quartos a imigrantes, economizando desta forma nas despesas.

As inúmeras estratégias para diminuir despesas são especialmente verificadas entre os que desejam voltar ao Brasil. Isso porque o projeto implica que se reduzam os gastos e se junte dinheiro. A maioria dos imigrantes com os quais se teve contato expressou a aspiração da volta. Contudo, nem todos estabelecem um prazo; de qualquer modo, alguns, tendo isso em vista, realizam investimentos no país de origem, comprando casas ou terrenos, carros ou apenas enviando o dinheiro para uma conta bancária. Cita-se na sequência alguns argumentos utilizados para justificar a vontade de voltar:

"eu aprendi muita coisa em Portugal. Foi uma coisa bacana, mas eu não trocaria o Brasil por Portugal, mesmo se eu tivesse ganhando rios de dinheiro aqui. (...) Eu não tenho o espaço que eu tenho no Brasil. No Brasil você tem direito a tudo e aqui você não tem direito. Você pode ter B.I., você pode ter tudo, mas você não tem direito porque você é imigrante, você sempre vai ser imigrante" ${ }^{\prime 47}$.

"Então o que que eu tenho aqui? Eu penso que eu estou perdendo muito, e a gente não pode ter tudo. A minha família, eu tenho cá família, mas veja bem, eu não constitui uma família para mim. Eu optei por não construir porque eu achei que não tinha nada a ver, filhos e marido, é complicado essa coisa toda, então eu optei por não constituir, mas eu sinto que eu perco muito. Por exemplo, a minha família lá cresce a cada dia que passa, cada vez que eu vou lá de férias eu estive lá em abril, é uma tristeza a volta, fica mais difícil, cada ano que passa fica mais difícil, chega aquele sofrimento, então esse ano eu me propus a voltar, mas devido a esse acontecimento eu sou obrigada a ficar aqui e dar essa força para o meu sobrinho, mas isso é só um ano mesmo, o ano que vem eu volto, tá muito certo"48.

"É assim, é um projeto, eu penso em voltar todos os dias, não é... E o meu marido também, pensa em voltar e ter lá ou um escritório dentro da área de direito, ou mesmo um negócio próprio, tenho casa lá...

\footnotetext{
${ }^{47}$ Entrevista com imigrante. Homem, Lisboa, pesquisa de campo, outubro de 2009

${ }^{48}$ Entrevista com imigrante. Mulher, Lisboa, pesquisa de campo, setembro de 2009
} 
Penso mais é assim, hoje, eu tenho só cá a minha irmã, e eu sinto muita falta da minha família, da minha mãe, dos meus avós, e a família do meu marido né, e os meus amigos também, isso faz parte"A9.

Percebe-se que os direitos e a família são importantes nos discursos referidos como elementos que influenciam na vontade de voltar ao país de origem. Mas os mesmos também estão presentes entre os que não querem voltar ao Brasil, especialmente por pessoas casadas com alguém nascido em Portugal. Em geral, esses últimos também argumentam freqüentemente que Portugal oferece melhor qualidade de vida. Nesse discurso se faz referências especialmente à violência no país de origem e maiores oportunidades em Portugal, as quais foram inexistentes no Brasil, notadamente as que se referem ao trabalho. Essas justificativas, conforme se pode observar a seguir, aparecem tanto em migrantes da primeira onda, como da segunda onda.

"Olha... tenho uma vida muito boa...em relação a que eu vivia lá no Brasil. Em termos de violência, aqui é muito melhor, emprego aqui é muito melhor, saúde, nem se fala... Então, quer dizer, eu já não consigo voltar lá pro Brasil... Pra viver não...

"O Brasil é um país assim... Eu nunca tive oportunidade no Brasil. Nunca tive oportunidade nenhuma lá. E é um país assim... que a violência muito, muito, muito bem diferente daqui. Então, eu não penso voltar a morar lá não"51.

"Eu acho que eu acostumei aqui, eu escolhi viver aqui, eu não consigo mais voltar pro Brasil... E outra que voltar, emprego vai ser difícil... onde eu morava é uma cidade pequena... eu teria que, se voltar, voltar pra lá... é complicado... então, eu prefiro ficar aqui... eu penso que seria voltar pra trás...,52

"As vantagens de se viver em Portugal são várias. Você vive em um país sem violência e um país que está inserido na Europa, então você tem uma facilidade de circulação, esse país tem um padrão de vida melhor... Espanha, Inglaterra, França, Portugal, a Europa de modo geral tem um padrão de vida melhor que os países da América Latina, pra mim isso é um diferencial, que leva a facilidades... Tem determinadas coisas que são mais difíceis no Brasil. Aqui você tem mais condições de comprar determinadas coisas que no Brasil são mais complicadas. A diferença aí é sócioeconômica,53.

Mesmo os imigrantes que não querem voltar ao Brasil afirmaram já ter passado por algum tipo de situação discriminatória. Aliás, todos os imigrantes

\footnotetext{
${ }^{49}$ Entrevista com imigrante. Mulher, Lisboa, pesquisa de campo, outubro de 2009.

${ }^{50}$ Entrevista com imigrante. Mulher. Enfermeira. Coimbra, pesquisa de campo, outubro de 2009.

${ }^{51}$ Entrevista com imigrante. Homem. Pintor. Lisboa, pesquisa de campo, setembro de 2009.

${ }^{52}$ Entrevista com imigrante. Mulher. Cozinheira. Coimbra, pesquisa de campo, outubro de 2009.

${ }^{53}$ Entrevista com imigrante. Homem. Historiador. Porto, pesquisa de campo, novembro de 2009.
} 
brasileiros entrevistados denunciaram esse tipo de ocasião, algumas experiências são relatadas abaixo:

\begin{abstract}
"Na primeira semana de aula. Uma colega de mestrado fez uma referência, que havia muitos brasileiros inseridos na universidades portuguesas, no trabalho, no mercado mesmo, que tava tendo uma expansão desses brasileiros, que muitos vinham pra cá... E aquilo na primeira semana de aula dentro de uma boa universidade me chocou muito, mas depois eu passei a ver que existem os portugueses que gostam muito dos brasileiros ou os portugueses que se sentem invadidos pelos brasileiros. Os que amam perdidamente os brasileiros e os que não gostam...". ${ }^{44}$
\end{abstract}

"Eu lavava carro para portugueses, eles as vezes não me respeitavam como um cidadão. Eles tinham o brasileiro como um encosto. Alguns amigos já passaram por situações em que disseram "volta pra sua terra", "isso aqui não é sua terra". Isso sempre acontece. Comigo acontece menos, porque como agora eu trabalho com idoso, mas eu já passei, no meu trabalho anterior, por preconceito. Já ouvi dizer de imigrante porque eles trabalham aqui, mas ao mesmo tempo eles gostam de brasileiro trabalhar porque brasileiro trabalha direito, ou seja, brasileiro faz mais horas, brasileiro se submete mais, vamos dizer assim..." 55

"Eu lembro que eu tive até uma discussão, foi logo que eu cheguei, porque eu sou daquelas que vou mesmo à razão. Eu lembro que eu cheguei num bar, já tava saindo num comboio, já tava vindo pra Lisboa, que eu trabalhava de segunda à sexta e de sexta à noite eu vinha pra Lisboa, aí eu cheguei estava na estação dos comboios e fui comprar um água, só que eu fiquei muito tempo no balcão, e todo mundo passava à minha frente, parecia que ninguém me ouvia e eu fui ficando assim, entrando em desespero, chegou uma hora que eu falei, peraí, quer ver como eles vão me ouvir? Eu dei um murro na mesa, sabe quando você fecha a mão e dá um murro? Eu dei um murro no balcão e disse: "eu estou aqui há horas e já paguei essa água (porque era pré pagamento, né) que eu quero beber e eu quero entender porque até agora eu não fui atendida?" Foi um silêncio total, né. Foi daí a primeira vez que eu realmente eu falei, aqui, neste lugar, você vai ter que se impor, senão vai ficar pra traz, e foi assim que comecei, a tipo: ok não gostou? Então é assim, assim e assim. Chama a pessoa à sua razão, percebeu? Pra poder falar com ela. Então por conta disso eu penso se teve eu cortei com a minha atitude e deixei bem claro que, olha, você não é melhor do que eu por conta disso, isso eu sempre fiz, aprendi em casa também, entendeu?" 56

Esses depoimentos testemunham, portanto, uma situação corriqueira, algumas vezes bastante disfarçada, outras vezes explícitas. De modo geral, os imigrantes são acusados de "roubar" postos de trabalho, vagas em universidades, etc. O curioso é que atitudes discriminatórias ocorreram principalmente em locais de trabalho, mas também em lojas, restaurantes e em universidades, nessa últimas partindo tanto de alunos como de professores.

\footnotetext{
${ }^{54}$ Entrevista com imigrante. Homem, Porto, pesquisa de campo, novembro de 2009.

${ }^{55}$ Entrevista com imigrante. Homem, Lisboa, pesquisa de campo, setembro de 2009.

${ }^{56}$ Entrevista com imigrante. Mulher, Lisboa, pesquisa de campo, setembro de 2009.
} 
Tais atitudes chocam muito os brasileiros e constituem-se para eles um grande desafio. Em certas ocasiões, por exemplo, as vítimas reagem com atitudes extremamente grosseiras, o que acaba por alimentar atitudes discriminatórias e até xenófobas por parte da população nascida no país, tornando-se assim objeto de preocupação dos Estados de origem e do Estado receptor.

Diante do que foi discutido nesse capítulo percebe-se que as relações entre portugueses e brasileiros são caracterizadas por complementaridade e conflito. No mercado de trabalho o conflito é mais tênue nos setores em que não há relações de concorrência entre a mão de obra dos nacionais e dos imigrantes, predomina, então, a complementaridade. No âmbito geral, estrangeiros e portugueses tem atitudes contraditórias com relação ao outro, ora se comportam de modo discriminatório, ora surge a mais sincera aceitação. Essa, porém tem maior alicerce e magnitude quando a convivência com o diferente e o conhecimento ao seu respeito compõem o cotidiano. Tal fato dá pistas para o sucesso de políticas estatais relativas à imigração em Portugal. 


\section{Capítulo 3 - Implicações do fenômeno migratório contemporâneo para as relações entre Brasil e Portugal}

$O$ fenômeno da migração gera transformações. No início do século $X X$, F. Ratzel e, depois, na década de 1950, M. Sorre incluíram em suas obras reflexões que indicavam: as migrações conferem novos dinamismos às sociedades ${ }^{57}$.

A idéia central era a de que ao migrar, os seres humanos "carregam" o meio consigo (Moraes, 1990), o que levaria a modificações no meio em que se instalam, disseminando características antes exclusivas do meio anterior, retirando áreas do isolamento. Sobre isso, Gourou (1984) afirmou:

"La época histórica de las migraciones a gran distancia ha sido responsable de fuertes transformaciones de la geografía humana. Revolución de la geografia humana de América, Siberia, Manchuria, Australia, Nueva Zelanda y Africa Del Sur. Desde el siglo XVI, por tanto en tan solo tres siglos, la mitad de la superfície de las tierras emergidas (de las tierras emergidas y no solamente de las tierras explotables) ha visto su geografia humana profundamente transformada por las migraciones" (p. 153).

As migrações são uma dimensão empírica dos movimentos do espaço geográfico. Enquanto tal provoca nele instabilidades e mudanças emergidas do seu embate com a ordem estabelecida na qual se insere ${ }^{58}$ (Gottmann, 1952). Esses dinamismos resultantes das migrações estiveram presentes no passado, como explicita a citação acima, e também estão presentes no período contemporâneo. Nesse sentido, é necessário refletir sobre as decorrências da alteração dos padrões migratórios mundiais que se deu na segunda metade do século $\mathrm{XX}$, observando mais atentamente as especificidades que se referem às migrações entre Brasil e Portugal. Esse esforço é realizado partindo de uma retomada do que já foi discutido nos capítulos anteriores, sintetizando os principais aspectos que levaram a essas transformações.

\footnotetext{
${ }^{57}$ Referência a algumas discussões presentes em textos que compõem os livros: MORAES, Antônio Carlos Robert (org.). Ratzel. Coleção Grande Cientistas Sociais, no 59. São Paulo: Editora Ática, 1990 e MEGALE, Januário Francisco. Max Sorre. Coleção Grande Cientistas Sociais, no 46. São Paulo: Editora Ática, 1984.

58 Jean Gottmann (1952) inclui as migrações entre os "fatores de movimento", os quais fazem o espaço fluir e mudar. Tais fatores encontram na ordem estabelecida uma tendência à autodefesa e manutenção da estrutura social e política que resiste às mudanças. Do conflito entre a instabilidade provocada pelo primeiro e da estabilidade desejada pela segunda, surgem e remodelam-se as divisões do mapa político mundial.
} 


\subsection{Pós-Segunda Guerra: novo mapa das migrações no mundo}

As inversões dos fluxos tradicionais foram reflexos das profundas mudanças no mundo a partir de 1945. Inicia-se aqui pontuando as que ocorreram na Europa.

Ruíram os impérios coloniais, o que implicou na perda daquilo que assegurava riquezas a esse continente. Mas a Europa se reconstruiu: consolidou-se o Estado de Bem-Estar-Social e superaram-se antigos conflitos e rivalidades.

Nos vinte e cinco anos que sucederam o fim da guerra, foram criados amplos sistemas de proteção social na Europa, que resultaram de uma sintonia entre Estados e sindicatos. Além disso, inicia-se o processo de integração, que foi o caminho escolhido para se fortalecer econômica e politicamente frente a duas superpotências exteriores ao continente, Estados Unidos e URSS (Szesz et alli, 2003).

Já nos países periféricos que obtiveram independências ainda no século XIX ressaltam-se as dinâmicas econômicas relativas à industrialização em meados do século XX. O Brasil, nesse contexto, atravessou uma fase de vertiginoso processo de crescimento econômico pautado na industrialização, por meio do modelo de substituição de importações. Paralelamente, verificouse intensa urbanização alimentada pelas migrações internas, especialmente aquelas que se dirigiam do campo para as cidades ${ }^{59}$.

O Estado brasileiro era dirigente do processo de industrialização. Segundo suas concepções na época, os sistemas produtivos dos países ricos eram modelos que deveriam e eram seguidos para se alcançar 0 desenvolvimento econômico e social do país. Adotaram-se também políticas sociais inspiradas no Estado do Bem Estar Social, mas isso foi feito de modo precário, contraditório e desprovido de bases sólidas para sua sustentação. No entanto, os efeitos dessas políticas possibilitaram significativa mobilidade social, as quais se associavam às migrações, nesse momento, fundamentalmente internas.

\footnotetext{
${ }^{59}$ Aqui não se deterá exaustivamente a esses processos. Mas pode-se encontrar uma análise meritória dos mesmos no livro: SANTOS, Milton. A urbanização brasileira. 5ª edição. São Paulo: Edusp, 2005.
} 
Todavia, os fluxos de emigração brasileira para os Estados Unidos e o Paraguai começam a se tornar relevantes já nessa fase, principalmente na década de 1960. O primeiro fluxo refletia os fortes vínculos econômicos e políticos entre os dois países, enquanto o segundo inseria-se na lógica da expansão da fronteira agrícola, a qual acabou extrapolando o limite territorial do Brasil.

Ao analisar as estratégias brasileiras na economia e na política mundial, Becker \& Egler (2003) demonstram que, de 1964 a 1974, o Brasil buscava impor-se ofensivamente na Bacia do Prata e mantinha forte aliança bilateral com os Estado Unidos. Os fluxos migratórios do Brasil para Estados Unidos e Paraguai refletem essas posturas. A respeito desse último fluxo, os geógrafos constatam que houve:

“(...)omissão face à ocupação física de terras do outro lado da fronteira por colonos brasileiros seja pela plantação de soja e aquisição de terras no Paraguai, seja pela penetração de seringueiros nas matas bolivianas - que davam continuidade à "Marcha para Oeste" (Becker \& Egler, 2003: p.155).

As independências das antigas colônias, por sua vez, mudavam o mapa político mundial. O hemisfério sul viu surgir novos países pobres e conheceu abrupto crescimento populacional, que decorreram da disseminação de melhorias médico-sanitárias e novas técnicas profiláticas, desenvolvidas nos países ricos. Tais processos incluíram, em alguns casos, guerras e agravamento da pobreza, os quais culminaram na emigração.

Dessa conjuntura decorreu a ampliação da imigração na Europa, diferentemente do que vinha ocorrendo há pelo menos três séculos. Embora no imediato pós-Segunda Guerra Mundial ainda predominasse a emigração nesse continente, à medida que se efetivou a descolonização aumentou a imigração, sobretudo daqueles que, tendo emigrado no passado, voltaram à sua terra de origem. Ao analisar os movimentos populacionais europeus a geógrafa Beaujeu-Garnier (1978), afirmou:

"É extraordinário como as afinidades de cultura e, especialmente de língua influem persistentemente na direção da emigração: os povos anglo-saxãos, de modo geral, vão para a América do Norte e para a Austrália, assim como os da Europa Central, ao passo que os povos do Mediterrâneo seguem principalmente, para a América Latina..." (p. 206). 
Mas os fluxos contrários aos aludidos no trecho anterior também eram uma realidade e avolumavam-se. Desse modo, as duas vertentes que compunham o saldo migratório eram fortemente influenciadas pelos laços culturais e pela língua, considerando que muitos imigrantes vinham das excolônias. Era grande e crescente, contudo, os estrangeiros europeus, principalmente dos países mediterrâneos.

Era o caso de Portugal, cuja longa trajetória extra-européia sofreu, neste período, uma inflexão. A perda de colônias e as necessidades econômicas e políticas deram início ao processo de "voltar-se ao continente", o qual iria expressar-se nas emigrações, desde a década de 1960, dirigidas principalmente para o interior do continente.

Portugueses, bem como espanhóis, italianos, dentre outros, em sua maior parte iam suprir as necessidades de mão de obra não especializada de países europeus em amplo desenvolvimento econômico. Construção civil, serviços de limpeza em hotéis e restaurantes são exemplos de setores que utilizaram essa mão de obra estrangeira em países como França, Reino Unido, Suíça e Alemanha (Beaujeu-Garnier, 1978).

Cabe lembrar que a emigração é um fator tradicional e constante, mesmo apresentando momentos de expansão e contração, que influenciou fortemente a evolução demográfica de Portugal. $O$ envelhecimento e 0 predomínio de mulheres em algumas áreas são aspectos desta população, que historicamente teve nos homens, adultos e jovens, os elementos mais propensos a deixar o país (Medeiros, 1976).

Evidentemente esses aspectos influíram pesadamente na economia do país, que internamente, além dos escassos recursos naturais, sofria com a debilidade do crescimento populacional. Isso, somado à sua posição periférica no continente europeu, davam às colônias e à emigração papel central na economia portuguesa. As primeiras garantiam riquezas, recursos e mercado consumidor, já os portugueses que viviam fora do país eram responsáveis pela entrada de importantes quantias de remessas.

Portugal só conheceria o incremento da entrada de estrangeiros em seu território a partir de 1975, como decorrência do fim da ditadura militar e da descolonização. Houve, portanto, um relativo atraso destes processos 
comparativamente ao restante da Europa. As colônias portuguesas na África foram as últimas a conquistar independência. Além disso, na França e no Reino Unido a imigração superava a emigração desde fase anterior ao fim da Segunda Guerra Mundial.

Mas do mesmo modo que no restante do continente, a imigração começa a aumentar no momento em que as colônias se tornaram independentes, com o retorno de portugueses que antes tinham emigrado para elas. Posteriormente, o fluxo manteve-se com cidadãos desses novos países e vem se renovando desde então. Em um primeiro momento, portanto, entram principalmente imigrantes africanos. A imigração de nacionais do Brasil para Portugal, conforme já explicitado, só seria mais relevante na década seguinte.

Portugueses que emigram para outros países da Europa desde 1950 e imigrantes de países terceiros que chegam a Portugal desde 1975 desempenham a mesma função no mercado de trabalho do país de destino, isto é, constituem-se em reserva de mão-de-obra não especializada. As necessidades desse tipo de trabalhadores no mercado de trabalho europeu, explica, portanto, a entrada de estrangeiros nos países. Mas, no caso português, este fato elucida, simultaneamente, sua emigração, inclusive na fase mais contemporânea.

Diante do exposto, fica evidente que o novo comportamento do fenômeno migratório em Portugal reflete a constituição da Europa em um continente que atrai para si fluxos de imigração, tanto de âmbito continental como extra-continental. Essa nova organização dos fluxos ocorre simultaneamente ao surgimento e fortalecimento de atores políticos supranacionais e o reconhecimento da existência de pessoas dotadas de direitos individuais, independentes do Estado, no sistema internacional (Reis, 2003).

Até o fim da Segunda Guerra Mundial o sistema internacional era composto primordialmente pelos Estados dotados de soberania e autonomia. Soberania e autonomia fundamentam-se, dentre outras características, no monopólio da legitimidade da mobilidade. Isso quer dizer que no sistema internacional tradicional os Estados decidem como controlar a entrada e saída dos indivíduos, das entidades privadas, dos fluxos de mercadorias e de capitais 
em seu território, entendido como contêiner de seu poder, de sua população e de seus recursos, delimitado por fronteiras. Conforme Reis (2003):

"dentro desse paradigma o indivíduo é um não-sujeito, isto é, não existe. Internacionalmente, Estados se relacionam com Estados, não existe uma relação entre indivíduos de uma nacionalidade e Estados de outra " (p. 11).

No que se refere às migrações internacionais, esse modelo implica aos Estados o poder de definir, a partir de seus interesses, quais imigrantes receber e o número de pessoas estrangeiras que podem entrar em seu território. Além disso, os Estados estabelecem os direitos que estendem ou não aos migrantes. Percebe-se, deste modo, que a regulação dos fluxos migratórios está nas mãos dos Estados receptores, sobretudo; enquanto Estados de origem tem pouca possibilidade de ação nesse sentido.

Desde 1945, porém, confirma-se paulatinamente a tendência supramencionada de novos atores supranacionais participantes do sistema internacional e do reconhecimento dos indivíduos. Quanto a este último citamse alguns marcos: o Tribunal de Nuremberg, que julgou os criminosos de guerra em 1945 e 1946; a Declaração Universal dos Direitos Humanos, declarada em 1948 no âmbito da ONU; a Convenção de Imigração para o Trabalho, em 1949, e a Convenção dos Trabalhadores Imigrantes, em 1975, produzidas pela Organização Internacional do Trabalho; a Convenção de Genebra, que versa sobre o status de refugiado, em 1951 e o Protocolo de Nova lorque, de 1967, que amplia esse conceito; a Convenção internacional sobre a Proteção dos Direitos de todos os Trabalhadores Migrantes e Membros de suas Famílias, de 1990 (Reis, 2003).

Este arcabouço normativo e os novos atores do sistema internacional transformam o direito internacional tradicional, pois constrangem a autonomia de decisão dos Estados. Isso se reflete nas migrações, pois tais constrangimentos impõem-se também no modo como o Estado formaliza o acesso ao seu território e à nacionalidade, a qual condiciona os direitos do cidadão (Reis, 2003).

Entretanto, esse constrangimento é relativo, considerando que a efetivação dos direitos dos indivíduos permanece dependendo dos Estados, que escolhem assinar ou não, ratificar ou não os documentos. De qualquer 
modo, ignorar por completo os migrantes como sujeitos de direitos, independentes de sua nacionalidade, pode trazer prejuízos às relações entre o Estado receptor e os demais atores no sistema internacional. Logo, verifica-se desde os anos que sucederam o fim da Segunda Guerra, a tendência à regulação das migrações não mais exclusiva dos Estados receptores.

\subsection{Migrações em tempos de globalização}

O fluxo de saída de portugueses para outros países europeus sofreram diminuição com as restrições impostas pelos principais receptores. Tais restrições foram motivadas pela crise econômica derivada do choque do petróleo de 1973, a qual atingiu duramente os países ricos.

A internacionalização da economia foi a solução encontrada pelos países ricos para superação da crise econômica. As empresas multinacionais foram verdadeiros instrumentos nesse sentido, passando a atuar também nos países pobres, onde buscavam mão de obra mais barata, incentivos fiscais e outros benefícios que as permitissem aumentar consideravelmente seus lucros, os quais, com freqüência, eram remetidos aos países em que estavam suas sedes.

As ações das grandes empresas, associadas à adoção de políticas neoliberais em países pobres, dentre outros fatores, levaram ao aprofundamento do processo de globalização, sobretudo após a década de 1970. Os setores de telecomunicações são emblemáticos da ação dos Estados Unidos e suas empresas multinacionais no sentido de desmantelar o controle nacional desse sistema técnico a fim de torná-lo subserviente a uma produção que se tornava transnacional. Estas ações culminaram na interligação do mundo tal como conhecemos hoje (Schiller, 2002).

Desde 1970 é crescente a dispersão da produção em todo o mundo, o que é permitido graças aos avanços técnicos, em especial ligados à informação, anexos aos avanços científicos. Aliás, ciência e técnica encontramse cada vez mais imbricados e subordinados às necessidades do mercado. $O$ conhecimento tornou-se recurso ao sistema produtivo (Santos, 2003). 
Por isso, hoje é crescente a relevância de setores que exigem mão de obra dotada de alta qualificação e especialização ${ }^{60}$. A internacionalização da economia, comandada pelas grandes empresas por meio da dispersão do processo produtivo à escala global, demanda técnicos, gestores, cientistas, dentre outros profissionais, nem sempre disponíveis na população autóctone. Os migrantes que se enquadram no perfil exigido, suprem essa carência.

Outra característica do presente é que a dispersão da produção fez emergir novos padrões de aglomeração. Desde o momento em que esse processo ganhou força, há lugares que centralizam o comando e garantem o funcionamento da globalização. Eles encontram-se interconectados por redes e possuem entre si elevado grau de interdependência, subordinando o restante dos territórios à sua lógica ${ }^{61}$. Neles desenvolvem-se setores altamente lucrativos, dentre os quais aqueles ligados às finanças e os serviços especializados.

A ampliação desses setores em lugares específicos do espaço geográfico faz com que aí se concentrem também os postos de trabalho melhor remunerados e exigentes de elevada qualificação. Considerando que as remunerações são diretamente proporcionais às qualificações exigidas, tais setores encontram-se no topo do mercado de trabalho atual.

O esquema 4 (Mercado de Trabalho na globalização) permite perceber que uma das características da globalização é que no mercado de trabalho predominam vagas pouco exigentes de qualificação e cujas remunerações são baixas. Em outras palavras, a base é mais volumosa que o topo.

\footnotetext{
${ }^{60}$ As discussões sobre migrações altamente qualificadas surgem na economia nos anos 1960, mas desperta maior atenção somente em meados dos anos 80 . As atenções foram dadas, em um primeiro momento, às possíveis conseqüências da "fuga de cérebros" aos países de origem, na outra vertente, às vantagens do "ganho de cérebros" nos países receptores. Uma síntese dos debates científicos sobre esse tema e suas repercussões políticas é encontrada em GÓIS, Pedro \& MARQUES, José Carlos. Estudo Prospectivo sobre imigrantes qualificados em Portugal. Estudos OI 24. Lisboa: ACIDI, 2007.

${ }^{61}$ Esses pontos estratégicos do espaço geográfico para a economia global são denominados por Santos (2003) de espaços do mandar e por Sassen (2003) de cidades globais. Ambos os autores destacam que esses lugares manifestam as contradições da globalização.
} 


\section{Esquema 4: Mercado de Trabalho na globalização}

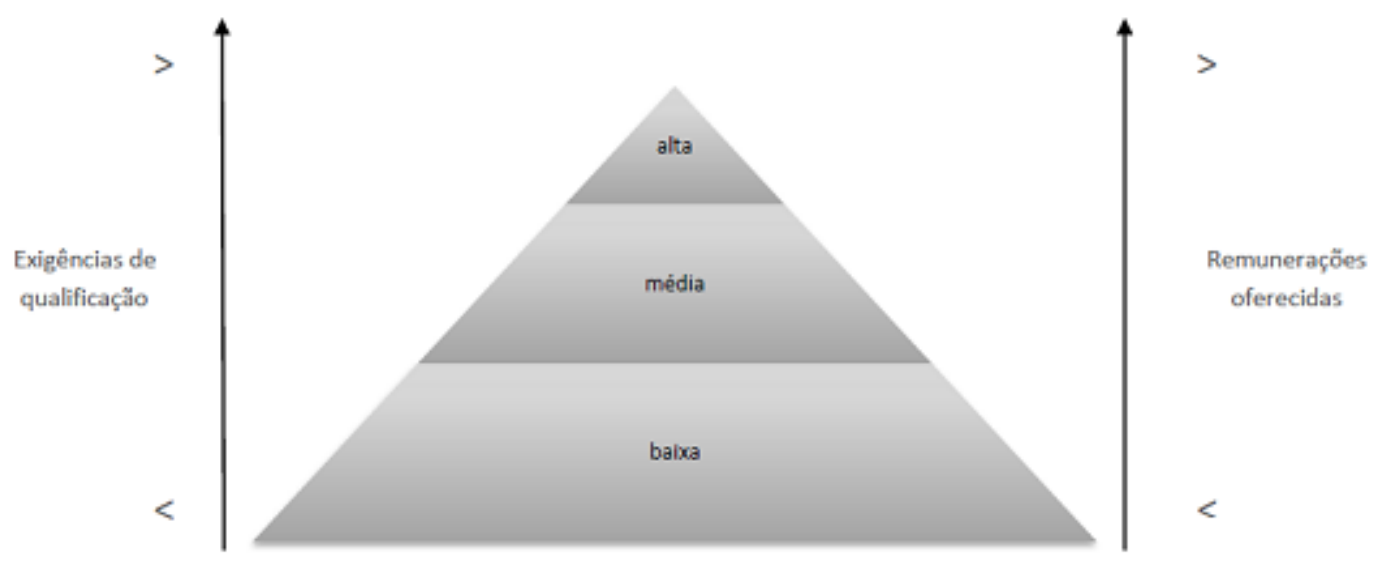

Número de vagas

Fonte: GÓIS, Pedro \& MARQUES, José Carlos. Estudo Prospectivo sobre imigrantes qualificados em Portugal. Estudos OI 24. Lisboa: ACIDI, 2007.

Organização: Aline Lima Santos.

Mas, é necessário salientar que tanto a base como o topo crescem no atual período. Ao mesmo tempo, o número de vagas cujas exigências e salários estão em patamares intermediários tende à contração. Isso decorre da perda relativa de importância das indústrias quando comparado aos setores de serviços.

O mercado de trabalho, contudo, terá configurações específicas a partir da inserção dos lugares, cidades, regiões ou países no mundo da globalização. Aquelas áreas que exercem papel de destaque no que se refere ao comando dos processos de âmbito global tendem a aproximarem-se mais do que foi descrito.

As análises sobre as funções de comando do processo de globalização exercidas por uma área podem partir das mais diversas escalas geográficas. Porém, os processos são seletivos e dependentes de uma base técnica difundida também de modo seletivo no território. Assim, há, paralelamente à dispersão da produção, concentração dos comandos em algumas cidades, as quais tornam-se escalas privilegiadas da análise do processo de globalização.

As aglomerações urbanas que possuem as características precedentes foram denominadas por Sassen (2003), dentre outros autores, de cidades globais. Presentes tanto em países ricos como países pobres, essas cidades 
contém setores que geram lucros elevados e são parte de grandes corporações líderes no mercado global. Mas em sua economia também existem setores desvalorizados, que respondem, dentre outras coisas, às necessidades cotidianas da população residente.

Pelo que foi explicitado, tais cidades são atualmente grandes receptoras de migrantes, tanto nacionais como internacionais. Nelas a expansão da demanda por trabalhos altamente qualificados alimenta a expansão da base do mercado de trabalho, em uma relação de complementaridade, conflito e contradições. Nestes extremos estão os setores que mais utilizam a mão de obra imigrante. Desse modo, se a França ainda hoje é um dos principais receptores de trabalhadores portugueses, é certamente em Paris que a maioria deles está concentrada.

Segundo estimativas do Observatório da Emigração (2010), 70 a 75 mil portugueses emigram por ano. Tais migrantes, além de engajarem-se em postos de trabalho que não demandam qualificações, preenchem também necessidades de segmentos altamente exigentes.

Adverte-se que a emigração de "cérebros" portugueses não é um fenômeno novo para o país. Desde a década de 1960, contudo, os fluxos voltaram-se para o continente europeu e aumentaram, refletindo o incremento geral dos níveis de qualificação da população portuguesa.

A abertura política e econômica de Portugal a partir de 1975 e à adesão a Comunidade Econômica Européia em 1986, aconteceram paralelamente ao aumento da demanda por profissionais altamente qualificados. Assim, na década de 1980, o país começa a atrair imigrantes capazes de suprir essas necessidades do mercado de trabalho. (Góis \& Marques, 2007).

A modernização decorrente desses processos de abertura, evidentemente, não impactou o território português de modo homogêneo, mas privilegiou a cidade de Lisboa e seu entorno, que centraliza e conecta-se diretamente às dinâmicas globais. Daí porque Lisboa concentra, em Portugal, parte significativa dos imigrantes, tanto aqueles altamente qualificados como não qualificados.

É justamente a partir da década de 1980 que a imigração brasileira aumentou no país. Em um primeiro momento, a maior parte das pessoas vindas do Brasil trabalhava em setores que careciam de mão de obra 
altamente qualificada ou estavam relacionados à atuação de empresas multinacionais.

Esse fluxo foi motivado pela crise econômica e política que atravessou o país e que, por atingir especialmente a chamada classe média, nela criou uma grande insatisfação, que a tornou propensa à emigração. Essa é direcionada a países com os quais se tem vínculos históricos, econômicos e culturais, dentre eles Portugal, o qual se encontrava em um estágio de prosperidade econômica vindo dos investimentos recebidos dos fundos estruturais da Europa Comunitária.

O arcabouço normativo referente a entrada e permanência de brasileiros em Portugal e de portugueses no Brasil foi outro incentivo para o fluxo. O documento mais recente é o Tratado de Amizade, Cooperação e Consulta entre a República Portuguesa e a República Federativa do Brasil assinado em 22 de abril de 2000, em virtude das comemorações do "descobrimento do Brasil".

Nele estabelece-se a isenção de visto pelo período de 90 dias aos que desejam entrar no território da outra parte contratante para fins culturais, empresariais, jornalísticos ou turísticos. E regulamenta o estatuto de igualdade, cujos beneficiários, brasileiros em Portugal e portugueses no Brasil, tem os mesmos direitos e deveres que os nacionais desses estados.

O status especial dado ao migrante brasileiro em território português é fruto, em certa medida, de acordos diplomáticos consolidados desde 0 reconhecimento de nossa independência ${ }^{62}$. Seguramente essa história acumulada de acordos que colocou Brasil e Portugal como "nações amigas", ainda que os fatos nem sempre as confirmem como tal, tem repercussões no sentido de incentivar as decisões de emigrar.

\footnotetext{
${ }^{62}$ Já em 1825, quando do reconhecimento da independência do Brasil por parte de Portugal, é assinado o primeiro Tratado de Amizade entre os dois países. Dentre as disposições aí presentes encontra-se a de que os cidadãos de ambos os países seriam "considerados e tratados nos respectivos Estados como os da nação mais favorecida e mais amiga e os seus direitos e bens devidamente protegidos" (Magalhães, 1999: p.32). Em 1953 é estabelecido o Tratado de Amizade e Consulta, cuja redação incluía a livre circulação e estabelecimento de portugueses e brasileiros nos dois países, obedecendo apenas as restrições colocadas pela saúde pública e segurança nacional. O artigo II do referido documento trazia:

"cada uma das Altas Partes Contratantes acorda em conceder aos nacionais da outra tratamento especial, que os equipara aos respectivos nacionais em tudo que de outro modo não estiver diretamente regulado nas disposições constitucionais das duas Nações quer na esfera jurídica, quer nas esferas comercial, econômica, financeira e cultural, devendo a proteção das autoridades locais ser tão ampla quanto a concedida aos próprios nacionais" (Magalhães, 1999: p. 199).
}

Diante do exposto, pode-se perceber que o Tratado assinado em 2000 é a versão mais moderna de acordos há muito tempo estabelecidos. Seu objetivo é, deste modo, ratificar as relações. 
Contudo, os acordos relativos aos brasileiros em Portugal e aos portugueses no Brasil são, especialmente a partir dos anos 1990, subordinados à integração européia. Portugal, como membro da União Européia (UE), busca conciliar os interesses do bloco com seus interesses particulares.

Em 1991, Portugal adere aos Acordos Schengen, que regula a livre circulação de pessoas no espaço comunitário europeu ${ }^{63}$. Suas políticas de imigração passaram, a partir de então, a privilegiar migrantes provenientes dos demais Estados membros. Conjuntamente tais Estados procuram definir políticas comuns aplicadas a países terceiros. Ao mesmo tempo, porém, Portugal opta por dar preferência a migrantes provenientes dos Países Africanos de Língua Portuguesa (PALOP) e do Brasil, o que ocorre, sobretudo, por motivações políticas e históricas.

Por isso Portugal não adere completamente aos direcionamentos da UE em detrimento de suas políticas nacionais e de tratados já estabelecidos com outras nações. É notório seu esforço no sentido de encontrar um equilíbrio entre os interesses divergentes que envolvem a questão migratória. Sobre isso, Santos[b] (2004) afirma:

"O discurso oficial do Estado (português) propõe 3 principais linhas de acção: integrar os imigrantes residentes; limitar ao máximo os fluxos migratórios à excepção dos países de expressão portuguesa e regular a imigração proveniente dos mesmos" (p.116).

Essa postura portuguesa significou aos brasileiros a transformação desse país em uma porta de entrada para o restante dos países da Europa. Alguns migrantes entram em Portugal com a intenção de aí se estabelecerem tempo suficiente para adquirir documentos que os permitam ir para outro destino europeu. Esse projeto migratório em duas etapas é justificado pela idéia de que, sendo brasileiro, é mais fácil entrar em Portugal e regularizar-se, comparativamente a outros países europeus.

Mas, se em janeiro de 2010 o salário mínimo em Portugal era de cerca $€ 500,00$, na França ele ultrapassava os $€ 1300,00$, na Inglaterra era pouco mais de $€ 1000,00$ e em Luxemburgo era superior a $€ 1600,00$. Em Portugal o salário

\footnotetext{
${ }^{63}$ Sobre as políticas referentes a imigração em Portugal e o status especial dado aos brasileiros ver SANTOS, Vanda. 0 discurso oficial do Estado sobre a emigração doa anos 60 a 80 e imigração dos anos 90 a actualidade. Porto: Observatório da Imigração, 2004
} 
mínimo é o mais baixo da Europa Ocidental ou, mais especificamente, dos países mediterrâneos ${ }^{64}$. Tal fato revela outra motivação dos fluxos de pessoas que daí partem, tanto nacionais, como estrangeiros.

Todavia, há casos de migrantes brasileiros que foram para outros países e, em decorrência das dificuldades encontradas, preferiram voltar para Portugal. Isso demonstra que nem sempre o projeto inicial de migração em etapas é bem sucedido, além disso, nem sempre ele é efetivado. A tendência é o estabelecimento definitivo nesse país ou o retorno ao Brasil, como é explicitado por um migrante:

"vim pensando em ficar aqui um tempo e depois ir para Inglaterra, mas só de pensar em passar por tudo de novo... A adaptação é muito difícil, cansa, procurar trabalho, chegar em um lugar completamente desconhecido... Então, desisti, prefiro ficar por aqui mesmo, porque já está tudo arrumadinho"

Além da adesão aos Acordos Schengen, deve-se destacar do mesmo modo o acirramento das relações econômicas entre Brasil e Portugal. Isso se deu, sobretudo, no período de privatizações no Brasil, fase em que aqui houve aumentou expressivo dos investimentos portugueses no setor de telecomunicações, acarretando, portanto, uma reaproximação entre os dois países. Atualmente, ambos esforçam-se no sentido de consolidar tais relações econômicas bilaterais com a finalidade de extrapolá-las tanto para o Mercosul como para União Européia. Evidentemente, tal aproximação também é um incentivador dos fluxos de um país para o outro.

O aprofundamento da integração na Europa por meio da adoção do euro e os atentados de 11 de setembro de 2001, somados aos recentes avanços sócio-econômicos no Brasil, aumentaram o volume da segunda onda migratória de brasileiros em Portugal, iniciada em 1998. A cotação do euro frente ao dólar o tornava mais atraente aos que queriam juntar dinheiro e retornar ao país de origem. Além disso, Portugal passou a ser visto como um destino alternativo ao

\footnotetext{
${ }^{64}$ No conjunto dos membros da União européia e dos candidatos a membros, os salários mínimos mais baixos são encontrados nos países do Leste, com destaque para a Bulgária $(€ 123,00)$. Os dados utilizados foram publicados pela revista portuguesa semanal Visão, na ocasião do ajuste no salário mínimo português no início de 2010. A reportagem, intitulada "Compare o salário mínimo português com os da UE e dos EUA" está disponível em http://aeiou.visao.pt/compare-o-salario-minimo-portugues-com-os-da-ue-e-dos-eua=f543243 (acesso: 29/09/2010).

${ }^{65}$ Entrevista com migrante. Homem. Cozinheiro. Pesquisa de campo, Porto, outubro de 2009.
} 
preferencial, Estados Unidos, que acirrou o controle de suas fronteiras para a circulação de pessoas.

Aumenta, portanto, em Portugal o fluxo de brasileiros com menor escolaridade. Esses respondem as necessidades de trabalhadores braçais, em setores desdenhados pelos nacionais, que muitas vezes preferem realizar os mesmos trabalhos em outro país, já que assim, podem ser melhor remunerados.

A comparação da entrada de brasileiros e da saída de portugueses torna evidente que o mercado de trabalho português demanda imigrantes para setores correspondentes aos que emigrantes portugueses se inserem nos países de destino. Isso esclarece que o grande motor dos movimentos populacionais continua sendo o capital e sua necessidade de ampliação e reprodução.

Compartilha-se aqui com a perspectiva de que no período atual a história é movida pela mais-valia à escala mundial. "Hoje haveria um motor único que é, exatamente, a mencionada mais-valia universal" (Santos, 2003: p. 29). Esse motor único só é possível porque é articulado a um sistema técnico único que engloba o planeta e subordina as técnicas não hegemônicas. As técnicas dominantes permitem também a convergência dos momentos e 0 conhecimento do planeta. Esses fatores sustentam-se entre si. Tomados conjuntamente eles fundamentam a globalização, conferindo ao espaço geográfico atual características ímpares na história.

Visto como conteúdo do espaço, o fenômeno migratório é, portanto, um dos processos que compõem a atual globalização (Sassen, 2003). Como um elemento da engrenagem do sistema, todos os demais elementos o influenciam e são influenciados por ele. Dito de outra maneira, as características atuais das migrações no mundo, independentemente do fluxo analisado, são inerentes aos fatores que sustentam e aprofundam a globalização. Mas as migrações respondem também a conjunturas e contextos específicos, pois a globalização atinge os lugares diferentemente.

Desse modo, é possível falar em uma correlação entre emigração e imigração em Portugal. Mas é errado supor que há substituição da mão de obra de nacionais pela mão de obra imigrante, pois existem outras variáveis que, articuladas de maneira complexa, participam destas dinâmicas. 
Deve-se lembrar os esforços de integração supranacional que se desenvolvem na União Européia, os quais implicam ações de fortalecimento de vínculos entre os países que a compõem e tem por objetivo reforçar a coesão entre os mesmos. É nessa estrutura que devem ser compreendidos, por exemplo, a realização de IDEs em Portugal, os quais, como já discutido, estimulam fluxos migratórios.

A internacionalização das universidades européias é outro exemplo de processo que influencia a emigração de portugueses. $O$ processo inclui programas de intercâmbio como o Esquema de Ação Regional Européia para a Mobilidade de Estudantes Universitários, mais conhecido pela sigla em inglês: "Erasmus". Esse programa de intercâmbio voltado ao Ensino Superior foi criado em 1987 e visa estimular a mobilidade acadêmica na UE. A participação no programa permite que os estudantes universitários estudem em outro país por um período de três a doze meses.

Tal política comunitária tem como premissa que o conhecimento e a informação são recursos primordiais para uma posição de excelência na globalização atual. Deste modo, seu objetivo é ampliar a qualificação profissional permitindo acesso às pesquisas e resultados científicos adquiridos em outros países. Além disso, visa facilitar as transferências de tecnologia entre países europeus e estimular a aprendizagem de outras línguas do espaço comunitário. Se fomentados e alcançados tais objetivos, mais uma vez, fortalecem-se os vínculos entre Portugal e o restante da União Européia, incentivando os fluxos migratórios.

Mas, além dessas políticas supranacionais, conforme já destacado, a emigração em Portugal é um elemento estrutural da sociedade. Entre suas conseqüências está sua capacidade de influenciar aspectos psicológicos daqueles que partem e daqueles que ficam. A interação entre ambos culmina na ilusão de que em outro país haverá trabalhos mais agradáveis, melhor remunerados, ou um ambiente mais interessante e satisfatório. Soma-se ainda aquilo que a geógrafa Beaujeu-Garnier (1978) denominou atração do grupo ou, para usar um termo da sociologia, a atuação de redes sociais.

Em síntese, as necessidades do mercado de trabalho europeu na globalização, as várias políticas comunitárias de fomento às afinidades entre os países da UE e a própria tradição emigratória em Portugal, dentre outros 
fatores, explicam a renovação da saída de pessoas no país. Os mesmos elementos influenciaram de modo diferenciado a ida de brasileiros a esse país nos últimos trinta anos.

A imigração brasileira ganha importância à medida que Portugal firma-se como membro da UE. Isso Ihe garantiu modernização de seu território, melhores condições de vida à sua população e uma reaproximação com o Brasil, refletida nos movimentos populacionais.

Tais movimentos articulados revigoram a histórica porosidade das fronteiras entre Brasil e Portugal (Lafer, 2003; Beck, 1999). Essa permeabilidade aos fluxos das mais diversas naturezas entre os dois países é incrementada pelas práticas cotidianas dos migrantes, como o associativismo e o envio de remessas, que conectam e reúnem país de emigração e de imigração.

\subsection{Políticas Migratórias no país de origem e destino e práticas transnacionais dos migrantes}

A mobilidade de pessoas encontra hoje a facilidade de atuar em territórios intensamente tecnificados, isto é, dotados de um conteúdo técnico que é resultado de avanços científicos colocados a serviço do mercado. Destaca-se aqui, principalmente, as técnicas relativas aos meios de comunicação e transporte.

Com essa base técnica a sua disposição no cotidiano, as possibilidades de relações entre as pessoas são ampliadas, concomitantemente alargam-se também a possibilidade de "teleação", isto é, a ação presente de pessoas, instituições, e organizações ausentes (Santos, 2003). Assim são alimentadas as redes sociais e as relações transnacionais.

As práticas transnacionais dos migrantes, há séculos, constituem os movimentos populacionais internacionais. Contudo, as bases técnicas hoje disponíveis permitem viver e agir simultaneamente em lugares distintos de modo instantâneo e independente da distância. Trata-se, pois, de uma novidade do tempo presente: a convergência de momentos (Santos, 2003; Beck, 1999). 
Por conseqüência uma das características das migrações internacionais contemporâneas é que a conservação dos vínculos com o país de origem torna-se mais intensa. Isso é expresso de diversas maneiras, como demonstram as remessas, as freqüentes visitas, os investimentos em bens imóveis, o associativismo, dentre outras práticas.

Os brasileiros em Portugal não fogem a essa característica. Embora presentes em território português, a inserção dessa população estrangeira se dá sem que, muitas vezes, os migrantes abram mão de sua vinculação, mesmo que fisicamente distante com o Brasil.

\subsubsection{Associativismo e políticas de imigração em Portugal}

Uma expressão de que os emigrantes brasileiros não abandonam completamente o país de origem é o surgimento da Casa do Brasil de Lisboa (CBL). Conforme o vice-presidente desta associação:

"A Casa do Brasil nasceu em 1992, na sequencia de um grupo de
brasileiros que se encontram aqui no período das grandes mobilizações
pelo impechment do Collor. Houve uma primeira manifestação em Portugal,
que adotou o "fora Collor" como no Brasil, e o pessoal se encontrou e
decidiu se manter organizado e faz uma Associação. A Casa do Brasil é
das primeiras, senão a mais antiga, não sei se mais que a Associação
Caboverdiana, mas é das mais antigas associações de imigrantes em
Portugal"66

Fica explícito no que foi dito que a mobilização dos emigrantes quanto a um fato político no país de origem foi fundamental para a constituição da associação CBL. Isso Ihe dá originalidade no conjunto das associações de brasileiros que vivem no exterior. Além disso, a CBL adquiriu relevância em sua atuação em prol de causas relativas a esse contingente populacional. Por isso essa associação será aqui a principal referência para as discussões referentes às políticas migratórias.

Antes, porém, merece atenção o fato de que o associativismo migrante não é um fenômeno novo. Trata-se de um "antídoto" comum contra a sensação de isolamento causada por se estar em terras estrangeiras. A estratégia é,

\footnotetext{
${ }^{66}$ Entrevista realizada com Luiz Leiria, vice-presidente da Casa do Brasil de Lisboa. Pesquisa de campo, setembro de 2009.
} 
portanto, formar grupos com os compatriotas e criar espaços de solidariedade e de encontros para troca de experiências, conhecimento, afirmação da identidade e da cultura do país deixado (Horta, 2010).

As funções das associações de migrantes relacionam-se a questões identitárias, sociais e materiais. Nesse sentido a ajuda mútua, a defesa de interesses dos migrantes, a preservação da herança cultural, a adaptação e a integração são algumas de suas preocupações. Quando formalizadas, muitas vezes as associações envolvem-se em questões sociais e políticas (Horta, 2010).

Portugal, por sua tradição na emigração, possui mais de 2800 associações espalhadas em todo o mundo. Só no Brasil, em 2010, conta-se 255. Tais instituições associativas são reconhecidas pelo Estado português que busca apoiá-las e estimular suas atividades a fim de manter-se em diálogo com aqueles que vivem no estrangeiro. Esse diálogo recebe contornos oficiais e formais com a instauração do Conselho das Comunidades Estrangeiras pela Lei n.. 48/96, de 4 de Setembro. Sua função é de caráter consultivo para as políticas relacionadas à emigração e às comunidades e ONGs de portugueses que vivem no exterior (Rocha-Trindade, 1995; 2010).

Como país de imigração, Portugal conhece crescimento do associativismo imigrante. Reconhecidas legalmente por meio da lei $n^{\circ} 115 / 99$, de 03 de agosto, que estabelece o Regime Jurídico das Associações de Imigrantes, hoje o país possui 124 associações, dentre elas seis brasileiras (Rocha-Trindade, 2010).

Das inúmeras associações brasileiras no mundo, cabe enfatizar o predomínio das igrejas, principalmente evangélicas. Em seguida existem aquelas que promovem a cultura e a língua portuguesa para os descendentes, e também as que privilegiam os esportes, em especial a capoeira e o futebol ${ }^{67}$. São em menor número as que extrapolaram tais objetivos de pertencimento cultural comum e ajuda sócio-econômica para assumirem como primordiais as questões políticas que envolvem os direitos de cidadania dos migrantes.

\footnotetext{
${ }^{67}$ Uma lista das associações brasileiras no exterior, resultado de pesquisa encomendada pelo Itamaraty junto às suas representações está disponível em: 
A maior parte das associações brasileiras existentes em Portugal, porém, atua na afirmação política das causas dos migrantes, o que se constitui em uma peculiaridade dessa comunidade brasileira no exterior. A CBL foi pioneira nesse sentido, focando sua prática na defesa e luta pela cidadania. Seu empenho tem sido o de aglutinar as outras associações brasileiras, mantendo também o diálogo com as associações representantes das demais comunidades estrangeiras em Portugal.

O que se nota no país é que a mobilização das associações de imigrantes tem logrado alguns êxitos junto ao Estado receptor. Isso se relaciona a articulação das associações com as organizações não governamentais, as quais tem conquistado relevância como interventoras sociais. Pode-se mencionar, dentre outras, a Obra Católica Portuguesa de Migrações (OCPM), o Centro Padre Alves Correia (CEPAC), o Serviço Jesuíta para os Refugiados (JRS) ${ }^{68}$.

Além disso, o Estado português, desde os anos 1990, reconheceu o associativismo imigrante como interlocutor e estimulador do processo de integração dos estrangeiros, abrindo-se, portanto, ao diálogo. Certamente esse reconhecimento é fortemente influenciado pela experiência associativa das comunidades portuguesas no exterior, com as quais o Estado mantém relações privilegiadas. Tais características levaram Carlos Viana, um dos vicepresidentes da CBL, a expor suas impressões de que:

"Portugal tem apresentado algumas particularidades positivas em termos de políticas de integração e legislação. Tem, por exemplo, uma lei própria sobre associações de imigrantes, o que parece ser uma particularidade no contexto da União Européia. Tem uma legislação geral (Lei de Entrada, Saída, Permanência e Afastamento de Estrangeiros) relativamente mais branda que muitos países europeus. (...) Aqui (...) a questão "Imigração e imigrantes" está longe dos radicalismos e perigos vividos em outros países europeus. (...) Neste contexto, as associações de imigrantes tem, em Portugal, um espaço de liberdade de atuação provavelmente maior que em outros países" (2010: p.220)

Soma-se, ainda, a existência de uma história compartilhada de experiências de imigração com os portugueses retornados do Brasil, muitos

\footnotetext{
${ }^{68}$ As organizações citadas foram visitadas durante pesquisa de campo em 2009. Nessas ocasiões foram entrevistados os respectivos diretores que, de modo geral, apresentaram as atividades realizadas pelas entidades e os edifícios nos quais se encontravam instalados.
} 
dos quais procuraram manter seus vínculos com o país que os recebeu. $A$ própria CBL conta com a colaboração de portugueses e outros estrangeiros.

Um de seus fundadores, por exemplo, foi o ex-padre e jornalista Alípio de Freitas, um português que migrou ao Brasil e aí se envolveu na militância por meio de movimentos sociais, como as Ligas Camponesas. Após alguns anos em que foi preso e torturado pela ditadura militar brasileira, Alípio de Freitas retornou a Portugal, onde passou a promover e dirigir associações com a CBL. Dentre os muitos outros casos de portugueses que participam dessa associação podemos citar, ainda, um dos atuais três vice-presidentes, Luis Leiria, que define a CBL como um "pedaço do Brasil em Portugal", conforme seu depoimento:

"Cheguei do Brasil e vim pra cá, fazer minha militância na Casa do Brasil, mas não sou brasileiro... Sou um caso um pouco... Eu costumo dizer que sou luso-brasileiro, porque eu nasci aqui, mas uma boa parte da minha vida adulta foi no Brasil... Comecei a participar logo que cheguei, em 1998, e lembro que as primeiras vezes que vim eu me senti muito bem, eu ainda estava vivendo o choque do regresso e era uma situação um pouco estranha assim... Quando eu voltei, eu não conseguia mais falar como o português de Portugal, então pra todo mundo eu era o brasileiro" "69.

As informações precedentes demonstram, deste modo, que há em Portugal um ambiente propício para que as associações influenciem as ações daqueles que decidem os rumos das políticas migratórias do país. Este favorecimento à organização e participação política dos imigrantes, porém, deve ser compreendido no âmbito do conjunto de políticas de população adotadas, considerando que essas se definem como:

"Medidas que têm um objetivo demográfico explícito, mas também uma parte daquelas que tem efeitos demográficos indiretos. (...) Fazem parte da política de população notadamente todas as medidas que afetam a função de reprodução humana, mesmo se dependessem a priori unicamente da política social. Assim ocorre com a legislação referente à família, ao casamento, à contracepção ou ao aborto. Encontram-se também incluídas as regulamentações relativas às migrações internacionais e mesmo, no fim, porque afetam a distribuição geográfica da população, alguns dados das políticas de organização do território" (Verrière, 1991: p.7)

\footnotetext{
${ }^{69}$ Entrevista com Luiz Leiria, vice-presidente da Casa do Brasil de Lisboa. Pesquisa de campo, setembro de 2009.
} 
Um dos principais problemas relacionados à população portuguesa é a tendência a queda no ritmo de seu crescimento e até mesmo o perigo de sua involução. Isso traz repercussões à economia do país, pois o número e a estrutura etária da população influenciam, junto com o poder aquisitivo, a capacidade de consumo, o qual estimula o mercado. Dito de outro modo, o envelhecimento populacional pode levar a baixo dinamismo econômico, para citar apenas uma de suas possíveis conseqüências negativas (Verrière, 1991).

Atenuar essa tendência é, notadamente, um dos objetivos das políticas de população em Portugal, que para isso lança mão das migrações internacionais. A entrada de estrangeiros é uma necessidade, pois como indica Fonseca (2007):

"Mesmo num cenário de fraco crescimento do emprego, será necessário recorrer a imigração para suprir o défice de população em idade activa e reduzir o risco de declínio da população do País e o despovoamento das áreas rurais menos desenvolvidas" (p. 119).

Portugal, então, admite-se como país de imigração e busca gerir esse fenômeno de modo a não prejudicar a coesão interna de sua sociedade. Assim, o país assume-se cada vez mais como intercultural, buscando promover 0 diálogo entre os diferentes imigrantes e os nacionais que constituem sua população, ainda que existam internamente setores da sociedade mais ou menos simpáticos à entrada de estrangeiros.

Independentemente de governos, portanto, o que se nota são esforços de regular os fluxos de imigração. Isso significa integrar os estrangeiros residentes, limitando a entrada dos mesmos, tornando os fluxos previsíveis e controlados, e discriminando positivamente aqueles provenientes dos países de língua portuguesa. Tudo isso, de modo a satisfazer o artigo 7 da Constituição da República Portuguesa, que versa sobre seus princípios fundamentais enquanto ator no sistema internacional ${ }^{70}$.

Como é de se esperar as políticas de imigração em Portugal envolvem diferentes órgãos e ações coordenadas entre si. Merece alusão a criação do Alto Comissariado para Imigração e Minorias Étnicas (ACIME), atual Alto

\footnotetext{
70 O artigo 7 da CRP dispõem sobre os princípios que caracterizam Portugal nas relações internacionais. Para os objetivos a que se propõem esse estudo, observa-se especialmente o parágrafo 4 e 5 , nas quais se destaca as afinidades com os países de língua portuguesa e com a Europa, objetos de atenção primordiais nas estratégias portuguesas de inserção no contexto internacional.
} 
Comissariado para a Imigração e Diálogo Intercultural (ACIDI), do Conselho Consultivo para os Assuntos da Imigração (COCAI), dos Centros Nacionais e Locais de Apoio ao Imigrante (CNAI e CLAI).

Esses órgãos públicos buscam conhecer o fenômeno da imigração em Portugal, conceber políticas a ele relacionadas e avaliar seus impactos. Além disso, por meio dos CNAI e CLAI, visam disponibilizar aos imigrantes serviços que satisfaçam suas demandas.

Os CNAls, por exemplo, reúnem em um só edifício as seguintes instituições: Serviço de Estrangeiros e Fronteiras (SEF); Segurança Social, Autoridade para as Condições de Trabalho; Ministério da Saúde; Ministério da Educação; Conservatória dos Registros Centrais. Os serviços oferecidos são: Gabinete de Apoio Jurídico ao Imigrante; Gabinete de Apoio ao Reagrupamento Familiar; Gabinete de Apoio Social; Gabinete da Saúde; Gabinete de Apoio ao Emprego; Gabinete de Apoio à Habitação; Gabinete de apoio ao Imigrante Consumidor; Gabinete de Resposta à Emergência Social ${ }^{71}$; Gabinete de Apoio Técnico às Associações; Rede Univa Imigrante ${ }^{72}$.

Incluído nas políticas de imigração em Portugal encontra-se o Plano de Ação para a integração dos imigrantes. Esse plano possui 122 medidas relacionadas aos temas: trabalho, habitação, saúde, educação, racismo e discriminação, igualdade de gênero.

Além disso, há programas voltados às Comunidade Ciganas, à integração de jovens e crianças $^{73} \mathrm{e}$, ainda, programas na televisão e no rádio que tem por objetivo sensibilizar a opinião pública sobre a realidade dos imigrantes no país e promover a interculturalidade. Há também o Centro de Apoio ao Imigrante no País de Origem, localizado em Cabo Verde, o qual oferece informações e orienta aqueles que querem ir para Portugal.

A esses órgãos, programas e ações relacionados à imigração em Portugal somam-se ainda seis processos de regularização desde o início da

\footnotetext{
${ }^{71}$ Esse último gabinete dedica-se à ajuda de pessoas que moram em outro país, mas precisam de tratamento médico em Portugal. A comunidade estrangeira que mais solicita esse serviço, segundo informações do próprio CNAI, é a cabo-verdiana.

72 A Rede Univa Imigrante possibilita trocas de informações sobre procura e oferta de empregos para imigrantes. Segundo informações obtidas em pesquisa de campo, a maior parte das vagas é oferecida para mulheres, especialmente para trabalho doméstico. Quanto aos homens, predominam as ofertas em construção civil.

73 Dentre os programas voltados a integração de jovens e crianças, destaca-se o Programa Escolhas, o qual envolve mais de 100 projetos por todo o país. Seu objetivo é reforçar a coesão social, buscando promover a igualdade de oportunidades. Mais detalhes sobre o Programa Escolhas podem ser encontrados em www.programaescolhas.pt.
} 
década de 1990. Os mesmos são listados a seguir: Decreto Lei 212/92 de 12 de outubro; Decreto Lei 244/ 1998 de 8 de agosto; Decreto Lei 97/1999 de 26 de julho; Decreto Lei 4/2001 de 10 de janeiro; Decreto Lei 34/ 2003 de 25 de fevereiro; e, a atual lei vigente 23/2007 de 4 de julho.

Os decretos-leis e leis acima citados incluem sempre menção ao tratamento especial dado aos imigrantes originários dos países de língua portuguesa. Contudo, nenhuma outra nacionalidade além da brasileira foi contemplada com um acordo específico, daí a relevância do Acordo Lula, celebrado em 2003.

Todos os documentos acima referidos sujeitam a regularização dos imigrantes à comprovação de atividade profissional remunerada. Possuir um contrato de trabalho em Portugal é condição para tornar-se imigrante em situação regular. Cerca de $90 \%$ dos estrangeiros de países terceiros que atualmente residem em condições regulares em Portugal foram beneficiados por esses processos, sendo um percentual significativo composto por nacionais do Brasil.

Existe, desta maneira, descompasso entre legislação referente à entrada e permanência de imigrantes e a prática dos mesmos. Tais documentos assumem, portanto, a magnitude das migrações irregulares em Portugal e limitam-se, de tempos em tempos, a oficializar uma prática já bastante difundida (Viana, 2010; Verrière, 1991).

As normas referentes à entrada de estrangeiros em Portugal permitem que a maioria dos imigrantes entre no país, de modo geral, com vistos de turista, passagem de volta, comprovante de renda para permanência no período pretendido e dados de reserva da hospedagem. Satisfeitas tais condições, pode-se ficar em Portugal por até três meses.

Nesse tempo, os imigrantes tentam encontrar trabalho que lhes ofereça contrato, já que isso possibilitará permanência no país de modo regular. Tal estratégia é uma prática comum entre os brasileiros. No entanto, nem sempre três meses é tempo suficiente para que os imigrantes encontrem trabalho que Ihes conceda contrato e há casos em que as promessas desse documento por parte dos patrões tornam-se verdadeiras chantagens.

Salienta-se ainda que a permanência em situação irregular em Portugal implica, quando do pedido de regularização, no pagamento de multas. A 
respeito das condições de regularização, a Consulesa do Brasil no Porto afirma:

"O patrão na verdade tem pouco trabalho: é inscrever o cidadão na segurança social e o resto é por conta desse cidadão que vai pagar as multas, pede dinheiro emprestado aqui e ali e paga as multas. Então, não é tão difícil assim se regularizar, só que não conseguem, porque o patrão tem... há uma resistência a dar o contrato... O patrão não vai ter muitos problemas com a lei. O problema vai ser do imigrante e de imigrantes eles se livram rápido" ${ }^{\prime 74}$.

Comumente os patrões portugueses que contratam imigrantes preferem aqueles que já se encontram em situação regular. Por isso, alguns imigrantes entrevistados compartilham da opinião expressa no depoimento a seguir sobre o processo de regularização:

"Eu acho que o Estado brasileiro e português deveriam fazer algo em relação ao visto de residência... Porque não devia ser necessário todo migrante ter um contrato de trabalho pra poder conseguir um trabalho... Porque aqui eles exigem assim... Você vai trabalhar e eles dizem: " - Tem residência? Então não... Ninguém te dá a primeira oportunidade, só dá o contrato pra quem tem residência. Acho que eles poderiam mudar esse lado...,

Cabe destacar que a regularização dos imigrantes é uma reivindicação constante dos movimentos associativos bem como das ongs que as apóiam. Tais entidades enxergam a situação de regularidade do imigrante como base para construção de sua cidadania na sociedade receptora. Por isso, todos os processos extraordinários contaram com as suas participações ativas, por meio de ações locais de base, para informar, sensibilizar, orientar e mobilizar os imigrantes para regularizarem sua situação (Pedro, 2010).

Para exemplificar, vale mencionar a criação, no período do primeiro processo extraordinário de regularização, do Secretariado Coordenador das Associações para a Legalização (SCAL), responsável por forte diálogo interassociativo. Esses contextos possibilitaram maior proximidade entre as organizações e fortalecimento do movimento associativo em Portugal. (Viana, 2010; Pedro, 2010).

\footnotetext{
${ }^{74}$ Entrevista com Dr. Cláudia d'Angelo, Chefa do Consulado Geral do Brasil no Porto, pesquisa de campo, novembro de 2009.

75 Entrevista com imigrante. Mulher. Doméstica. Lisboa, pesquisa de campo, outubro de 2009.
} 
Todo o conjunto de medidas que compõem as políticas de imigração em Portugal e as práticas de entidades e dos próprios imigrantes colocam o país como dos mais favoráveis à integração comparativamente aos demais países da UE. Essa foi a conclusão a que chegou o Migrant Integration Policy Index (Mipex), responsável pela avaliação das políticas de integração dos imigrantes dos países europeus (UE-25) e ainda Canadá, Noruega e Suíça.

O Mipex considera para as análises o acesso dos imigrantes ao mercado de trabalho; as condições para o reagrupamento familiar; a possibilidade de residência de longa duração; a participação política; a aquisição de nacionalidade e as políticas antidiscriminação. Levando em conta diversos fatores em cada um desses componentes, elabora-se uma escala que varia de 0 a 100, onde a maior pontuação representa as melhores práticas possíveis de integração.

\section{Gráfico 18: Portugal e as políticas para integração, situação em 2006}

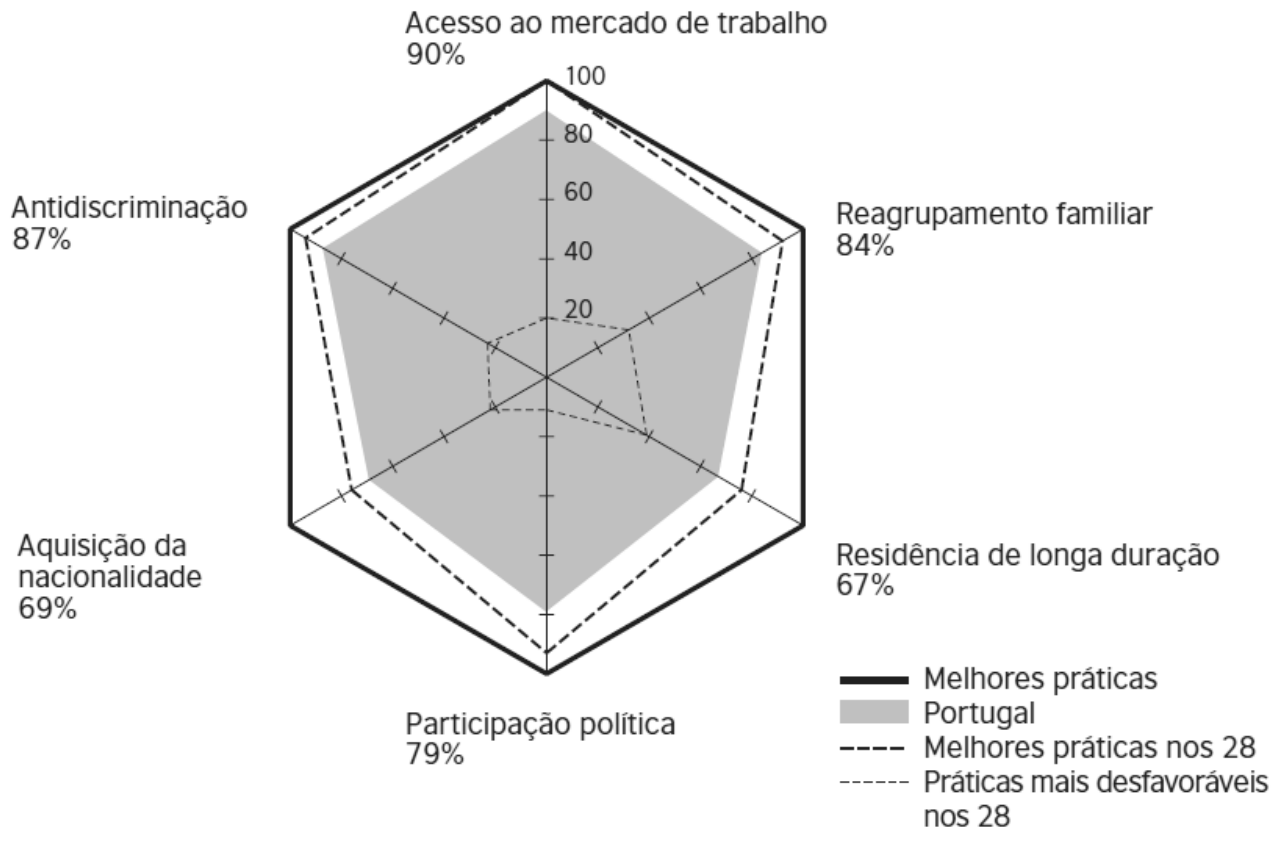

Fonte: NIESSEN, Jan (et alli). Migrant Integration Policy Index. Bruxelas: British Council \& Migration Policy Group, 2007, p. 146.

Em 2006, a Suécia, primeiramente, e, na sequência, Portugal destacavam-se no conjunto dos 28 países avaliados como os que ofereciam as melhores práticas à integração. Chipre e Letônia, por sua vez, apresentaram as 
práticas mais desfavoráveis. O gráfico 18 (Portugal e as políticas para integração, situação em 2006) sintetiza os dados referentes à Portugal, permitindo comparações com as situações extremas nos 28 países considerados.

Os dados permitem inferir que as políticas portuguesas referentes ao acesso do imigrante ao mercado de trabalho e a antidiscriminação são os pontos fortes para promoção da integração no país. Portugal é o segundo país da UE que mais favorece a criação de iguais oportunidades de trabalho para imigrantes e nacionais; contudo, o reconhecimento das competências dos trabalhadores imigrantes é sujeito aos acordos com o país de origem e frequentemente dependem de processos demorados, caros e burocráticos. Quanto à antidiscriminação, o quadro legislativo português baseia-se em definições e conceitos claros, o que é positivo, mas o Mipex sugere melhorias nos mecanismos de implementação, como a maior participação das ongs no apoio às vítimas (Niessen, 2007).

A participação política dos imigrantes em Portugal está igualmente sujeita a acordos bilaterais com o país de origem, o que demonstra que poderia ser ampliada a todos os imigrantes residentes no país. Mesmo assim, a posição portuguesa no conjunto dos 28 países considerados em 2006 o situa atrás apenas de Luxemburgo (Niessen, 2007).

Com relação às políticas de aquisição de nacionalidade e residência de longa duração, Portugal ocupa a quinta e a terceira posição, respectivamente, dentre os demais países. São, portanto, as mais limitadas para promoção da integração dos imigrantes. Essa limitação, aliás, é uma característica comum na UE-25, especialmente após a década de 1970, momento em que o elevado número de imigrantes em alguns países os fez rever as políticas de nacionalidade e de imigração (Reis, 2003).

Tais barreiras à integração certamente baseiam-se no fato de que no sistema internacional tradicional a cidadania é atrelada ao Estado territorial. Os Estados controlam a identidade das pessoas na medida em que atribuem aos nascidos em seu território sua nacionalidade, de maneira independente da vontade dos mesmos. As pessoas, portanto, inserem-se em um "contêiner social" com o qual compartilham uma identidade, imposta e incorporada e construída em movimentos de incessante ir e vir. 
Nessa relação se estabelece os deveres das pessoas para com a coletividade e as instâncias que a representam, primordialmente o Estado, 0 qual, em contrapartida, concede-Ihes direitos. A partir do exposto, percebe-se facilmente a indissociabilidade entre cidadania e nacionalidade (Reis, 2003).

As migrações internacionais, ao subverter tais relações, exigem que os Estados definam as regras de acesso ao seu território e à sua nacionalidade, para, enfim, deliberar as condições de acesso à cidadania. Deste modo, políticas de imigração e nacionalidade são intimamente vinculadas, levando-se em conta que:

"Antes de qualquer coisa, para se definir quem é o imigrante, é preciso se definir quem é o nacional. Além disso, o Estado tem que definir se quer que o imigrante se torne nacional ou não, que tipo de imigrante pode ser nacional, e quais são os critérios adequados para esse processo" (Reis, 2003: p. 25).

Em síntese, essa tarefa implica ao Estado "definir quais são os direitos exclusivos dos cidadãos, e de que forma uma pessoa pode ter acesso a eles" (Reis, 2003: p. 26). As políticas de imigração e nacionalidade moldam-se aos interesses dos Estados. Tais interesses transformam-se ao sabor de conjunturas econômicas, demográficas, sociais e políticas. Mas sua evolução e os discursos que a acompanham permitem apreender a imagem que a sociedade receptora constrói de si mesma, já que implicitamente responde à questão "quem somos nós?" bem como aponta para a construção futura do que será o "nós" (Reis, 2003).

O reconhecimento internacional dos direitos dos indivíduos implica no enfraquecimento dos nexos entre nacionalidade e cidadania. Por sua vez, o aumento da importância política dos inúmeros atores sociais, supranacionais ou não, constrangem o poder soberano do Estado. Consequentemente, no âmbito internacional emerge a tendência à migration governance compreendida aqui como formas de regulação internacional das migrações que resultam de acordos entre Estados, organismos internacionais, movimentos sociais, dentre outros atores (Jacinto, 2002).

Entretanto, o que se nota é, ao mesmo tempo, a afirmação do papel central desempenhado pelo Estado na definição do que é adequado para as políticas migratórias. Conforme afirma Domenech (2008): 
"Entendemos que el Estado sigue siendo um actor clave en la formulación y aplicación de la política migratória, ya que em virtud de la soberania nacional posee la atribución de permitir, restringir o rechazar la entrada y permanencia de los inmigrantes así como determinar los derechos y obligaciones (diferenciales 0 no) de los habitantes - a quienes clasifica como "nacionales" o "extranjeros" - de acuerdo al principio de nacionalidad. Em este sentido, siempre resulta necesario considerar las diferencias entre aquellas políticas dirigidas a los emigrantes y a los inmigrantes" (p.60)

Sob essa perspectiva, como membro da União Européia, a Portugal é imposto um padrão de comportamento relativo aos imigrantes de países terceiros, que implica, por exemplo, na adoção de medidas que intensifiquem o controle dos fluxos ou o combate a imigração irregular. A aprovação da Diretiva de Retorno ${ }^{76}$ pelo Parlamento Europeu, em 18/06/2008, representa mais um esforço nesse sentido.

Portugal tem atendido aos direcionamentos da UE. Contudo, isso não é feito em detrimento de seus interesses e de tratados já estabelecidos com outras nações. Conjugando esses fatores, que às vezes se apresentam conflitantes, o país adota uma identidade híbrida no cenário político internacional: Portugal é um país europeu e também um país de língua oficial portuguesa. As políticas de imigração que adota refletem essa identidade e tornam-se instrumentos para afirmá-la, pois, visam:

"a valorização da identidade portuguesa (através da promoção da língua e cultura Portuguesas...); consolidação das comunidades européias; combate às tendências para uma excessiva continentalização da Europa, pela manutenção de uma ligação atlântica reforçada por um acrescido diálogo político-econômico e pela cooperação triangulada com países terceiros, e o aprofundar do excelente relacionamento entre Portugal e os Países Africanos de Língua Oficial Portuguesa assim como a ligação com o Brasil" (Santos, 2004: p.113)

As políticas portuguesas relativas à emigração também influenciam nas políticas de imigração. Elas são produto do não rompimento completo, por parte do emigrante, de suas relações com seu país de origem. A longa tradição da emigração fez o Estado português desenvolver estratégias para tirar

\footnotetext{
${ }^{76}$ A Diretiva de Retorno estabelece normas e procedimentos comuns entre os Estados-Membros para o regresso de imigrantes irregulares provenientes de países terceiros.
} 
proveito desse recurso populacional fora de seu território, o que é comprovado, por exemplo, pelas facilidades que criou para captação de remessas.

As experiências acumuladas ao longo de séculos constituíram-se em verdadeira mais-valia para lidar com o recente fenômeno da imigração. As políticas de imigração portuguesas são profundamente influenciadas pelas políticas voltadas aos seus emigrantes, sendo as últimas, fontes inspiradoras das primeiras. Tal fato, conforme já exposto, é evidenciado pelo reconhecimento das associações de emigrantes portugueses no mundo e, posteriormente, de imigrantes em Portugal.

Resta, por fim, mencionar que as práticas do Estado português com relação aos imigrantes são percebidas de modo diferenciado pelos mesmos. Os brasileiros que chegaram há mais tempo, que são mais politizados ou lidam diretamente com a legislação referente aos imigrantes tendem a elogiar as políticas de imigração adotadas no país receptor, como se pode observar nos testemunhos:

"Acho que o Estado português faz até bastante pelos imigrantes, mesmo, mesmo, entendeu? Eu acho que o Estado protuguês faz bastante, e procura mostrar isso. Tem uma defesa muito grande em relação aos migrantes, que os próprios nacionais às vezes não tem. Isso infelizmente acontece. Só que tem um porém: tudo é muito caro. Por exemplo você vai no SEF e tudo custa dinheiro, deixou passar um dia... Por exemplo, tinha que pagar no dia 30, deixou passar um dia, paga uma multa, sabe? ${ }^{77}$.

"Eu acho até que Portugal, em termos de acolhimento, o Estado de português em termos de legislação é favorável. É favorável, porque eu também já estive muito a ler a regularização de estrangeiros aqui, e é favorável! Trabalho muito com o SEF, então eu sei, e até Portugal tem recebido muitos elogios a nível europeu pela sua legislação"78.

Por outro lado, embora influenciem diretamente o cotidiano de suas vidas, é comum, por parte dos brasileiros, o desconhecimento quase total das leis do país. Isso ocorre especialmente entre os recém chegados e entre aqueles que possuem menor grau de instrução ou que são menos politizados. Tal fato aumenta o grau de vulnerabilidade dos migrantes. Para exemplificar cita-se o caso de um imigrante que foi assaltado e não quis prestar queixa na

\footnotetext{
${ }^{77}$ Entrevista com imigrante. Mulher. Atendente. Lisboa, pesquisa de campo, setembro de 2009.

${ }^{78}$ Entrevista com imigrante. Mulher. Advogada. Coimbra, pesquisa de campo, outubro de 2009.
} 
polícia com medo de ser deportado, uma vez que estava em condição irregular no país. O mesmo se passa em casos de problemas de saúde. São muitos os imigrantes, que mesmo doentes, não procuram atendimento hospitalar temendo a deportação ${ }^{79}$.

\subsubsection{Associativismo e políticas brasileiras relativas aos emigrantes}

No sistema internacional tradicional, o estreito vínculo da cidadania ao Estado territorial leva a que a emigração tenha conseqüências relacionadas aos direitos e deveres das pessoas que partem de seu país de origem. Em primeiro lugar, o emigrante fica praticamente desprovido das garantias de concessão de seus direitos por parte do Estado, visto que tal concessão é limitada ao seu território. Por outro lado, as obrigações da pessoa para com a sociedade e o Estado quase que desaparecem quando ela o deixa.

Tradicionalmente, "são os países de imigração que, ao menos em teoria, controlam as migrações internacionais, já que definem o número e as categorias das pessoas que entram" (Rocha-Trindade: 1995,p.314). O Estado de origem pouco pode fazer pelos emigrados, suas ações muitas vezes limitam-se à defesa da mobilidade geográfica e profissional, a igualdade de tratamento em relação aos nacionais do país receptor, a garantia de preservação da identidade cultural do imigrante, facilidades no de envio de remessas, dentre outros.

Com a afirmação dos ideais democráticos e a valorização das liberdades individuais, no fim do século $X X$, somou-se a esses aspectos tradicionais 0 reconhecimento por todos da emigração como um direito. Assim sendo, atualmente há uma discrepância no modo como Estados democráticos encaram a emigração e a imigração. Se sair é permitido para todos aqueles que desejam, a entrada é controlada e sujeitada a interesses específicos dos países de destino. Essa discrepância foi mencionada por Heller (1996):

"Entre los pocos derechos humanos universalmente reconocidos está el derecho a emigrar (...) Del reconocimiento de esta necessidad se sigue que culquiera que desee emigrar puede hacerlo. Se presupone por definición que si alguien quiere emigrar, puede hacerlo porque la emigración es uma

\footnotetext{
${ }^{79}$ Tais casos foram presenciados em pesquisa de campo e evidenciaram o medo da deportação com o qual convivem muitos brasileiros em situação irregular em Portugal.
} 
necessidad legítima (socialmente adscrita) de esa persona. Sin embargo, no existe el derecho a inmigrar. Antes de admitir emigrantes, los gobiernos ponen a prueba si sus necesidades son reales o verdaderas en otras palabras, hacen exactamente lo que no deben hacer; pero no pueden evitar de hacerlo..." (p.116)

Seria possível, desta maneira, concluir que os países de origem possuem, contemporaneamente, ainda menos poder de defender os direitos dos que partiram. Contudo, nota-se justamente o contrário.

As fragilidades e consequente enfraquecimento do Estado de BemEstar-Social nos países ricos e a adoção de políticas neoliberais em países ricos e pobres culminaram no fortalecimento do poder da sociedade civil organizada em todo o mundo. No momento em que o Estado passou a exercer debilmente suas funções sociais ou mesmo abdicá-las, o descontentamento e descrédito levaram à pulverização de iniciativas que visavam compensar as perdas. As organizações originadas por essas iniciativas ganharam cada vez mais espaço de participação política, tornando-se atores políticos importantes tanto na escala nacional como na internacional.

Muitas dessas entidades envolveram-se com a temática migratória de modo direto ou indireto e colaboraram para transformação dos discursos políticos referentes à migração. Trata-se, pois, de um elemento que diferencia o sistema internacional do período contemporâneo, isto é, aquilo que Domenech (2008) denomina "cidadanização da política migratória":

\begin{abstract}
"lejos de la ldea de gerenciamiento de la política, la noción de "ciudadanización" es entendida aqui como un proceso sociopolítico que resulta de los distintos modos de intervención y legitimación que desarrollan los organismos internacionales y los Estados nacionales em matéria de políticas públicas y de las diferentes estrategias de participación que despliegan ciertas instituciones de la sociedad civil como las organizaciones de inmigrantes, los organismos de derechos humanos y las instituiciones eclesiales. En términos de política migratoria, la ciudadanización estaria dando cuenta de dos hechos intimamente articulados: por un lado, la creciente participación de los movimientos y organizaciones de la sociedad civil en la determinación de los asuntos migratórios $y$, por el outro, el formal reconocimiento y extensión de derechos civiles, sociales, econômicos, políticos y culturales a los migrantes, tanto a los inmigrantes como a los emigrantes" (p.54)
\end{abstract}

Em decorrência disso, hoje, os países de origem são chamados a participar mais ativamente dos debates sobre as migrações. Assumem, deste modo, o consenso e a corresponsabilidade como palavras de ordem em suas 
relações com os países receptores. Há, por isso, tendência à cooperação, multilateralização e até mesmo transnacionalização da formulação das políticas migratórias, as quais passam a considerar as organizações da sociedade civil como parte das estratégias de aplicação das medidas que visam atingir o fim proposto.

Uma das expressões empíricas desses processos foi o reconhecimento das associações de imigrantes em Portugal. Tal ação do Estado português contribuiu para o fortalecimento político dessas entidades. O peso político da $\mathrm{CBL}$ dentre as demais associações de brasileiros no exterior encontra aí parte de seus fundamentos. $O$ caso dessa associação permite compreender porque, em relativamente pouco tempo, os brasileiros emigrantes conseguiram estabelecer íntimas relações com o Estado brasileiro, especialmente a partir de 2002.

Devem ser consideradas as especificidades na formação desta associação. A CBL nasce baseando-se na participação, ativismo e interesse pela política do país de origem, fortemente influenciada pela militância política de esquerda, especialmente por meio do Partido dos Trabalhadores (PT). Conforme Viana (2010):

\begin{abstract}
"Alguns de seus fundadores estiveram ligados ao Partido dos Trabalhadores (PT) de Lula da Silva, na década de 80 e 90. Seu sócio no1, Alípio de Freitas, dirigente da CBL muito ativo desde a fundação até há poucos anos atrás, foi um militante histórico e lendário da esquerda brasileira desde finais da década de 50. (...)Outros membros da direção e co-fundadores da CBL (...) estiveram ativos na fundação do PT no Brasil e na criação do núcleo do PT em Portugal. Em 1994, vários membros da direção da CBL abandonaram sua militância no núcleo do PT de Portugal, entre outras razões, para que não se confundisse a associação com esta atividade partidária" (p.210).
\end{abstract}

Como já foi referido anteriormente, o movimento associativo de imigrantes brasileiros em Portugal contou com a colaboração de portugueses retornados do Brasil. Quando imigrantes nesse país, muitos desses portugueses se envolveram em associações ou militaram por meio de partidos políticos dentre os quais se destaca o PT.

A volta dessas pessoas a Portugal somou-se ao aumento do fluxo de brasileiros para esse país, muito dos quais motivados por, além de insatisfação econômica, insatisfação política com relação aos rumos seguidos pelo país que 
deixavam. Na ocasião das campanhas brasileiras para Presidente da República em 1989, o candidato Luís Inácio Lula da Silva visitou Lisboa e sua delegação contatou aqueles que haviam militado pelo PT no Brasil, solicitando apoio dos mesmos. Forma-se, então, um comitê de apoio ao candidato. Tal organização desdobrou-se, alguns anos depois, na criação do núcleo do PT em Lisboa $^{80}$, a qual se deu paralelamente à constituição da CBL.

Ressalva-se que são minoria os brasileiros emigrantes mobilizados politicamente. Contudo, sabe-se que a maior parte dos que se envolvem na vida política são partidários do PT. Ao analisar a participação política dos cidadãos brasileiros no exterior, Chelius (2007) destaca:

“(...) a participação regular, organizada e mais militante dos brasileiros no exterior, se canaliza através dos partidos existentes no Brasil, com destaque, no quadro da história política recente, para o partido que representou a oposição durante longo período, o PT liderado por Lula da Silva. Neste tipo de participação, existem núcleos - não necessariamente numerosos, mas de grande activismo - de simpatizantes e militantes desse partido, sediados em diferentes cidades de instalação de emigrantes brasileiros, como Boston, Miami e São Francisco nos Estados Unidos e, principalmente, Lisboa, Paris e Londres na Europa. São especialmente estes núcleos, como o que está radicado em Lisboa, que se tornaram interlocutores directos do governo brasileiro, assim que o partido de sua militância (PT) chegou ao poder em 2002" (208).

Em 2002, concorrendo novamente à Presidência da República do Brasil, Luís Inácio Lula da Silva faz algo inédito na história brasileira: inclui promessas eleitorais voltadas especificamente aos emigrantes. O documento conhecido como "Carta aos brasileiros que vivem longe de casa" foi enviado primeiramente para a CBL, depois encaminhada para outros representantes de emigrantes brasileiros (Chelius, 2007). Segue, na íntegra, os compromissos assumidos:

“- Apoiar a criação de organismos de representação dos emigrantes junto aos Consulados e Embaixadas para definirmos em conjunto as ações que podem ser implementadas pelo Estado brasileiro com o fim de assegurar seus direitos. Para tal, fortaleceremos as estruturas desses órgãos para oferecer um atendimento digno aos emigrantes brasileiros.

- Criar instrumentos nos Ministérios de Relações Exteriores e da Justiça para coordenar o atendimento e apoio aos emigrantes. Buscar ampliar e garantir a efetivação de acordos bilaterais entre o Brasil e os países de acolhimento, com o objetivo de assegurar $o$ atendimento das necessidades

80 Mais detalhes sobre a formação e atuação do núcleo do PT em Lisboa está disponível em http://www.ptlisboa.org/index.html, acesso em 07/10/10. 
de nossos compatriotas, concernentes à Seguridade Social, reconhecimento de títulos ou de equivalência na educação média e superior, atendimento no sistema de saúde etc.

- Reduzir as taxas bancárias cobradas pelo Banco do Brasil para remessas mensais a seus familiares, isentando as remessas inferiores a US $\$ 500.00 \mathrm{e}$ criando produtos financeiros específicos, a fim de viabilizar o acesso ao crédito para a aquisição de casa própria no Brasil.

- Procurar construir também os caminhos para que os brasileiros vivendo longe de casa possam contribuir para a abertura de novos mercados para nossos produtos, favorecendo principalmente seus municípios e estados de origem.

Ao mesmo tempo, estaremos implementando no Brasil um conjunto de políticas que vão garantir a retomada do desenvolvimento, com a possibilidade de criar 10 milhões de empregos até 2006. Os micros e pequenos empreendimentos industriais, comerciais e de serviços terão um apoio especial para que floresçam amplamente. Estou seguro de que antes do final do governo estaremos eliminando as principais causas econômicas e sociais que levaram vocês a terem que deixar o nosso país. Dessa forma, os que desejarem, deverão ter condições de voltar e viver dignamente." (Silva, 2002)

A partir de 2002, verifica-se no Brasil, portanto, uma maior sensibilidade com relação às necessidades de emigrantes brasileiros, a qual culminará em políticas concretas voltadas a esse contingente populacional fora do país. Tal fato relaciona-se à dispersão de militantes do partido, que então assumia o governo. Dispersão essa que remonta aos exílios promovidos pela ditadura militar e que, ainda hoje, é referência simbólica na vida política daqueles que saíram do Brasil (Chelius, 2007).

As relações entre o PT e a CBL, a chegada do PT ao poder no Brasil, o reconhecimento das associações pelo Estado português inseriram-se na conjuntura mundial de maior espaço político conferido às entidades da sociedade civil organizada. Tais elementos foram responsáveis pela constituição da CBL como uma plataforma de propostas que solicitam desses Estados ações que satisfaçam as necessidades dos migrantes. Tal como observa Viana (2010):

"o ponto alto desta prática se materializou no chamado Acordo Lula, que foi um resultado direto dum trabalho intenso e articulado de sensibilização da $C B L$ junto ao governo e ao poder legislativo brasileiros e à opinião pública. Em conseqüência o governo brasileiro tomou a iniciativa de propor um Acordo Diplomático bilateral, possivelmente o único do gênero, firmado nos últimos 20 anos entre um país terceiro e um país da União Européia. Recentemente, em 2007, a CBL conseguiu convencer o Ministro brasileiro das Relações Exteriores, Celso Amorim, a promover uma reunião no Brasil com representantes da emigração brasileira vindos de todo o mundo. Tal aconteceu em Julho de 2008 e se repetiu em outubro de 2009, marcando 
uma viragem na relação institucional entre emigrantes e Estado brasileiro" (p. 231).

A CBL, porém, não se foca apenas nas relações com os Estados, mas possui amplo debate e articulação com outras associações nos demais países que recebem migrantes brasileiros, em especial na Europa. Sua atuação extrapola-se para além dos países de origem e destino e torna-se transnacional. Tal como observa Viana (2010):

"Muito recentemente, a Casa do Brasil promoveu a primeira reunião de associações ligadas à comunidade brasileira em Portugal (maio de 2009), quando se decidiu o fortalecimento da articulação entre as mesmas. No plano europeu, aconteceu em Barcelona, no final de junho de 2009, o primeiro encontro da Rede de Brasileiras e Brasileiros na Europa, em cuja coordenação está a Casa do Brasil em nome de 3 associações brasileiras em Portugal".

Atuação da CBL e demais associações brasileiras no mundo deram visibilidade à emigração brasileira junto ao Estado de origem. Dessa forma, colaboraram intensamente para uma mudança de postura do Estado brasileiro quanto aos emigrantes.

Tal fato expressa-se na promoção da I e da II Conferência das Comunidades Brasileiras no Exterior: "Os Brasileiros no Mundo", promovida pelo Ministério das Relações Exteriores e Fundação Alexandre Gusmão em 2008 e 2009. Essa iniciativa está associada à idéia de se buscar um diálogo entre os representantes das comunidades brasileiras no mundo com o Estado, visando suprir necessidades e demandas e conhecer as características dos emigrantes. Dentre os vários temas debatidos encontram-se a melhoria nas condições de atendimento nos Consulados, questões referentes à previdência, o acesso à educação para os filhos dos emigrantes, a indocumentação.

$\mathrm{Na}$ mesma direção de buscar compreender e suprir necessidades dos que vivem fora do país, o Estado brasileiro, por meio do Ministério do Trabalho e Emprego e outras instituições, percebeu a insuficiência de informações disponíveis sobre os direitos e deveres dos emigrantes. Por isso, lançou uma cartilha entitulada "Brasileiros e Brasileiras no Exterior", em 15 de janeiro de 2008. Nela o emigrante encontra orientações gerais a respeito dos preparativos da viagem e dos documentos, alertas sobre as dificuldades de se viver no exterior e as desvantagens da irregularidade, a lista de serviços oferecidos 
pelos Consulados e Embaixadas brasileiros, a necessidade de se conhecer bem os direitos e deveres para com o país de acolhimento, dentre outros assuntos.

É interessante na apresentação do texto o destaque dado ao fato de que atualmente o Brasil vive um bom momento no que se refere às oportunidades de trabalho e emprego. Recomenda-se, em vista disso, no parágrafo 05:

"Em sua avaliação, informe-se melhor acerca das possibilidades de trabalho e emprego no Brasil. Nos últimos anos, nosso país vem registrando crescimento contínuo, com significativa recuperação da atividade econômica e reflexos positivos na elevação do nível de emprego formal".

Dessa maneira, a emigração no país é interpretada como conseqüência das dinâmicas econômicas, especialmente as específicas sobre o mercado de trabalho. A promoção estatal de novos postos de trabalho e o incentivo ao crescimento econômico, logo, são tomados como meios para controlar as saídas. Trata-se, portanto, de uma política de população, pois visa influenciar indiretamente o comportamento da mesma.

Estão presente no documento, também, orientações para que o emigrante procure no país de acolhimento órgãos e instituições de apoio ao imigrante e forme redes sociais e organizações que facilitem sua integração. Claramente há nesse caso, uma divisão das responsabilidades do Estado com tais entidades, as quais têm também importante papel político e, por isso, são importantes aliados na complexa discussão sobre os migrantes entre os países envolvidos no fluxo

Essas ações do Estado, somadas às conferências, dentre outros eventos, fortaleceram as relações entre representantes das comunidades e 0 Estado, e permitiram avanços significativos nas políticas. Nos últimos oito anos foram implementados programas de regularização; acordos previdenciários, informatização e reforma do sistema consular; canais de comunicação direta com os emigrantes por meio do Portal Consular, do Portal das Comunidades, da Ouvidoria Consular; criação do site www.brasileirosnomundo.mre.gov.br, que disponibiliza diversas informações de interesse dos emigrantes; e, por fim, assinado o Decreto ㄲ⒎214 de 15 de junho de 2010. 
Com esse documento instaura-se explicitamente no Brasil uma política de Estado para os emigrantes. Seus princípios e diretrizes baseiam-se no reconhecimento do direito à emigração; na disponibilização de informações sobre os requisitos necessários para entrada e saída em outros países; no aumento da interação emigrantes-Estado brasileiro; na promoção de autodesenvolvimento e melhores condições de vida aos emigrantes e seus filhos; no incentivo à produção de conhecimento referente à essa parcela da população fora do território nacional; no incentivo à preservação da identidade dos brasileiros e nos vínculos com o Brasil; no aproveitamento do potencial dos brasileiros no exterior; na atuação diplomática em defesa dos direitos dos emigrantes.

As medidas previstas incluem a realização anual das Conferências Brasileiros no Mundo e a criação do Conselho de Representantes de Brasileiros no Exterior (CRBE). O objetivo do CRBE é assessorar o Ministério das Relações Exteriores em assuntos de interesse dos emigrantes. Vianna (2010) enfatiza a participação da CBL em tais processos permitindo inferir que o modo como Portugal desenvolveu estratégias para manter vínculos com os emigrantes foram inspiradores para o Brasil.

Tratam-se, em suma, de avanços consideráveis e importantes no que se refere à população emigrada. Apesar disso, porém, seu alcance é limitado já que a cidadania dos migrantes é ainda frágil, como é notado no depoimento abaixo:

"Desde que a pessoa tenha o visto, trabalhando com o contrato, eu acho que ela deveria ser respeitada como deve ser, como cidadã. Já que ela tem o visto do país, ela é cidadã, ela está contribuindo com o país. Eu acho que ela deve ter os mesmos direitos que o português tem e que o português tenha no Brasil os mesmos direitos que o brasileiro tem. E as vezes não é bem assim que funciona as coisas. Muitas vezes você não consegue alugar um apartamento, por exemplo, só pelo fato de ser migrante. O visto seria para facilitar a vida do brasileiro aqui ou do português lá, mas eu vejo que não é bem assim" ${ }^{81}$.

\footnotetext{
${ }^{81}$ Entrevista com imigrante. Homem. Vendedor. Lisboa, pesquisa de campo, outubro de 2009.
} 


\subsubsection{Remessas de migrantes no Brasil e em Portugal}

No comportamento dos migrantes, uma das principais expressões das ligações com o país de origem e das relações transnacionais que estabelecem são as remessas. Essas são constituídas por pequenas quantias de dinheiro enviadas com diferentes fins, dentre eles, ajuda à família, poupança, pagamento de dívidas e freqüentemente estão associadas ao desejo do regresso (Rossi, 2007).

A análise das remessas no que se refere ao seu volume e impactos depara-se sempre com a limitação da aquisição de dados e discrepâncias existentes entre as fontes oficiais. Isto ocorre, dentre outros fatores, porque é freqüente o uso de meios informais por parte dos migrantes no envio de dinheiro para o país de origem e pela falta de coordenação entre as instituições de coleta das informações. Por conseguinte, as informações apresentam-se incompletas e aquém da realidade.

Apesar disso, é cada vez maior a atenção dispensada às remessas por parte de muitos pesquisadores e instituições, dentre elas o Banco Mundial. Geralmente, as discussões a esse respeito inserem-se na preocupação de avaliar os impactos das migrações nos países de origem e destino.

Evidentemente, o saldo migratório terá papel central na participação de um país nos fluxos de remessas mundiais. Como não poderia deixar de ser, quanto maior o número de imigrantes residentes em um país, maior será o volume de remessas enviadas para o exterior; em contrapartida, quanto maior o número de emigrantes, maior o volume de remessas recebido.

Ao observar os fluxos de remessas no mundo, constata-se que a maior parte tem o sentido Norte-Sul, isto é, saem de países ricos para países pobres (ver figura 10: Fluxos de remessas internacionais, situação no período 20062007). Em 2009, o volume de remessas direcionadas aos países pobres foi de cerca de 316 bilhões de dólares e, conforme estimativas do Banco Mundial, deverá apresentar crescimento de mais de 6\% em 2010 e 7\% em 2011. 
Figura 10: Fluxos de remessas internacionais, situação no período 2006

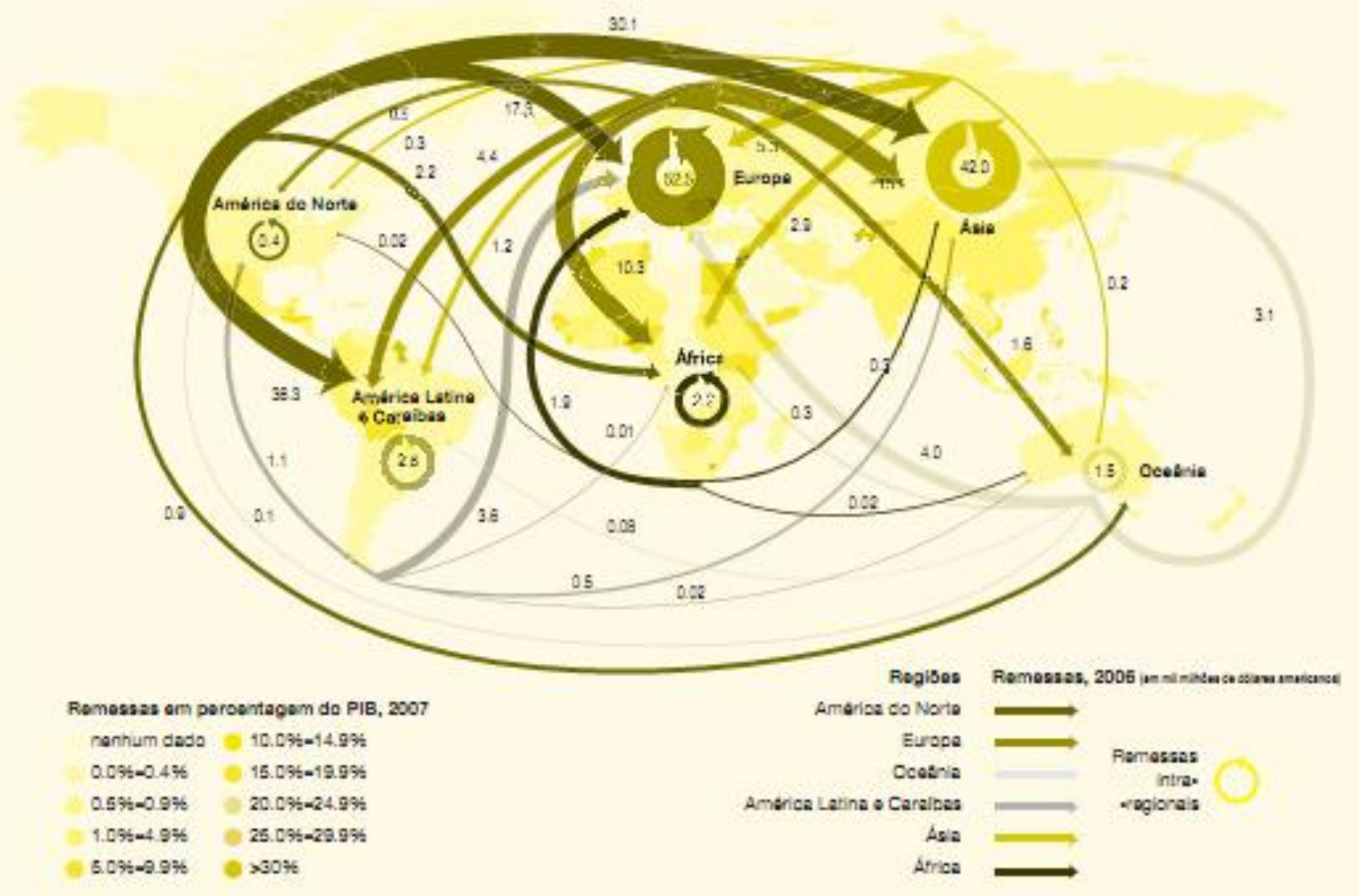

Fonte: PNUD. Relatório de Desenvolvimento Humano 2009. Ultrapassar Barreiras: Mobilidade e Desenvolvimento Humanos. Coimbra: Edições Almedina, 2009.

Ao considerar os valores absolutos, os Estados Unidos lideram a lista dos países que mais enviam remessas: 48 bilhões de dólares em 2008 (Banco Mundial, 2010). Mas, se tomadas em relação ao PIB, elucida-se a relevância dos fluxos que partem dos países em desenvolvimento: o volume enviado por imigrantes residentes no Líbano, por exemplo, ultrapassou $12 \%$ de seu PIB em 2008.

Um exame cuidadoso da participação do Brasil e de Portugal nos fluxos das remessas exigirá observar além daquilo que se envia também o que é recebido e, em síntese, o saldo. Observa-se na figura 10 (Fluxos de remessas internacionais, situação no período 2006-2007) que as remessas recebidas por esses países pouco representam em relação do PIB. Em 2008, corresponderam a 1,8\% do PIB de Portugal e 0,3\% do PIB do Brasil; em relação aos IED a proporção é ainda menor: 0,7\% e 0,1\%, respectivamente. Em valores absolutos isso significa entradas de aproximadamente 4 bilhões de 
dólares no primeiro e quase 5 bilhões no segundo, conforme dados do Banco Mundial (2010).

Tais montantes tem proporções comparáveis com as divisas obtidas por alguns importantes produtos de exportação desses países. Em 2008, as divisas provenientes das exportações de açúcar brasileiro somaram 5,4 bilhões de dólares e, em 2009, o café exportado pelo Brasil gerou cerca de 4,3 bilhões de dólares, valor próximo ao que foi enviado pelos emigrantes no mesmo ano: 4,2 bilhões de dólares. Estes volumes colocam o Brasil como segundo principal recebedor de remessas da América Latina, atrás apenas do México (BID, 2004; Banco Mundial, 2010; Notícias agrícolas, 2010; Unica, 2009;).

O gráfico 19 (Brasil e Portugal: fluxos de entrada de remessas no período 1975 - 2009) permite comparar a evolução da entrada de remessas no Brasil e em Portugal. No período considerado as remessas recebidas por Portugal mantiveram-se bastante superior as recebidas pelo Brasil, quadro que só irá se alterar em 2004, quando os fluxos de entrada nesse país atingem 3,5 bilhões e, em Portugal, 3,3 bilhões.

Gráfico 19: Brasil e Portugal: fluxos de entrada de remessas no período 1975 2009

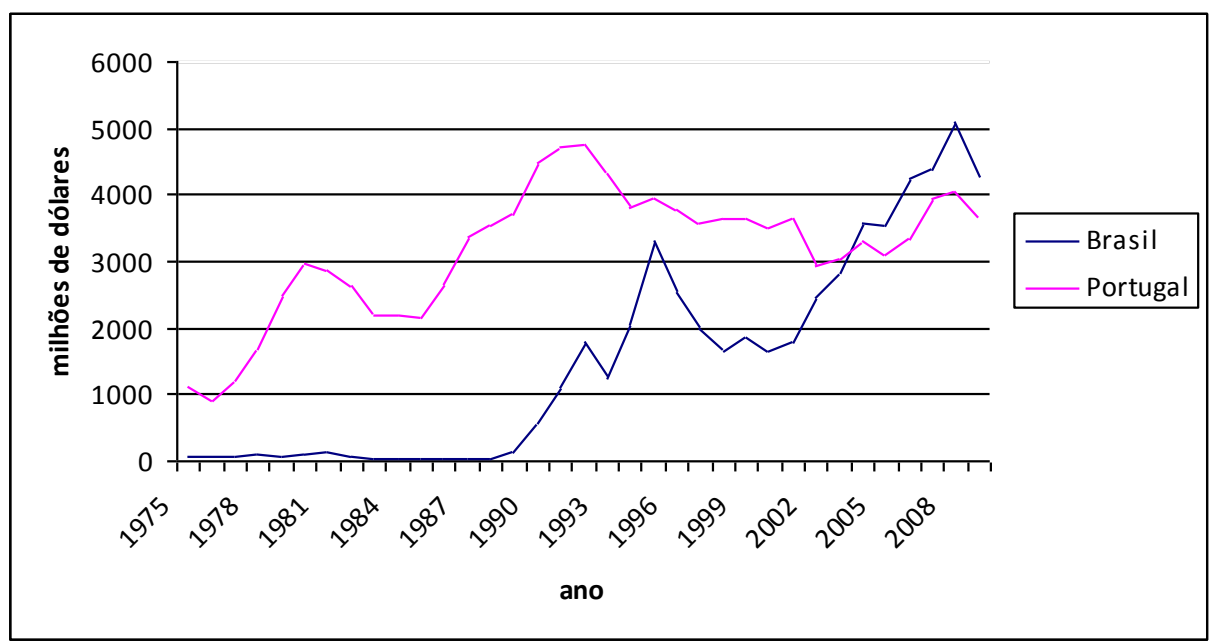

Fonte: Banco Mundial. Migration and remittances, 2010.

Conforme o que se observa, os fluxos de entrada ganham volume no Brasil apenas a partir de 1990, mantendo-se superior a 1 bilhão de dólares desde 1991. De 2001 até 2008 há crescimento significativo das entradas, que se firmam acima dos 2 bilhões de dólares desde 2002. A queda observada a 
partir de 2008 deve-se, dentre outros fatores, à crise econômica que atingiu os principais países receptores de migrantes brasileiros.

Em Portugal, nota-se que as entradas sempre estiveram acima dos 1 bilhão de dólares, com exceção do ano de 1976, quando registra-se o mínimo no período considerado: 924 milhões de dólares. Apesar das quedas e crescimentos conjunturais, há trinta anos as remessas em Portugal mantém-se acima dos 2 bilhões de dólares.

A Tabela 3 (Brasil e Portugal: percentual dos fluxos de entrada por origem das remessas, situação em 2008) mostra que Portugal e Brasil contam com uma variedade de origem dos fluxos que os torna menos sujeitos às grandes oscilações comparativamente a países como o Equador, por exemplo, em que a maior parte dos fluxos de remessas provém dos Estados Unidos e da Espanha.

Tabela 3: Brasil e Portugal: percentual dos fluxos de entrada por origem das remessas, situação em 2008

\begin{tabular}{|c|c|c|}
\hline Origem das remessas & Brasil & Portugal \\
\hline África & 0 & 3,1 \\
\hline Ásia & 31,9 & 0,3 \\
\hline Europa & 27,3 & 62,4 \\
\hline América Latina e Caribe & 11,2 & 12,1 \\
\hline América do Norte & 29,1 & 21,2 \\
\hline Oceania & 0,5 & 0,8 \\
\hline total & 100 & 100 \\
\hline
\end{tabular}

Fonte: PNUD. Relatório de Desenvolvimento Humano 2009. Ultrapassar Barreiras: Mobilidade e Desenvolvimento Humanos. Coimbra: Edições Almedina, 2009.

Mais de $88 \%$ das remessas que chegam ao Brasil são provenientes da Ásia, Europa e América do Norte. Japão, Estados Unidos e, na Europa, Reino Unido e Portugal sobressaem como grandes emissores desses fluxos, o que se explica por serem destinos preferenciais de brasileiros emigrantes.

Em Portugal, mais de $86 \%$ das remessas recebidas veem da própria Europa e da América do Norte. França, Suíça e Estados Unidos, constituem-se em grandes emissores, já que muitos emigrados portugueses residem em seu 
território. As remessas oriundas da América Latina e Caribe somam mais de $12 \%$, aí o principal emitente é o Brasil.

Portanto, Brasil e Portugal, além de receberem, também enviam remessas um para o outro. Até início dos anos 1990 prevaleceram os fluxos que saíam do Brasil e direcionavam-se para Portugal. Agora são preponderantes aqueles que partem deste último para o primeiro, contudo, isso não implica inexistência dos fluxos no sentido contrário.

Gráfico 20: Brasil e Portugal: fluxos de saída de remessas no período 1975 2008

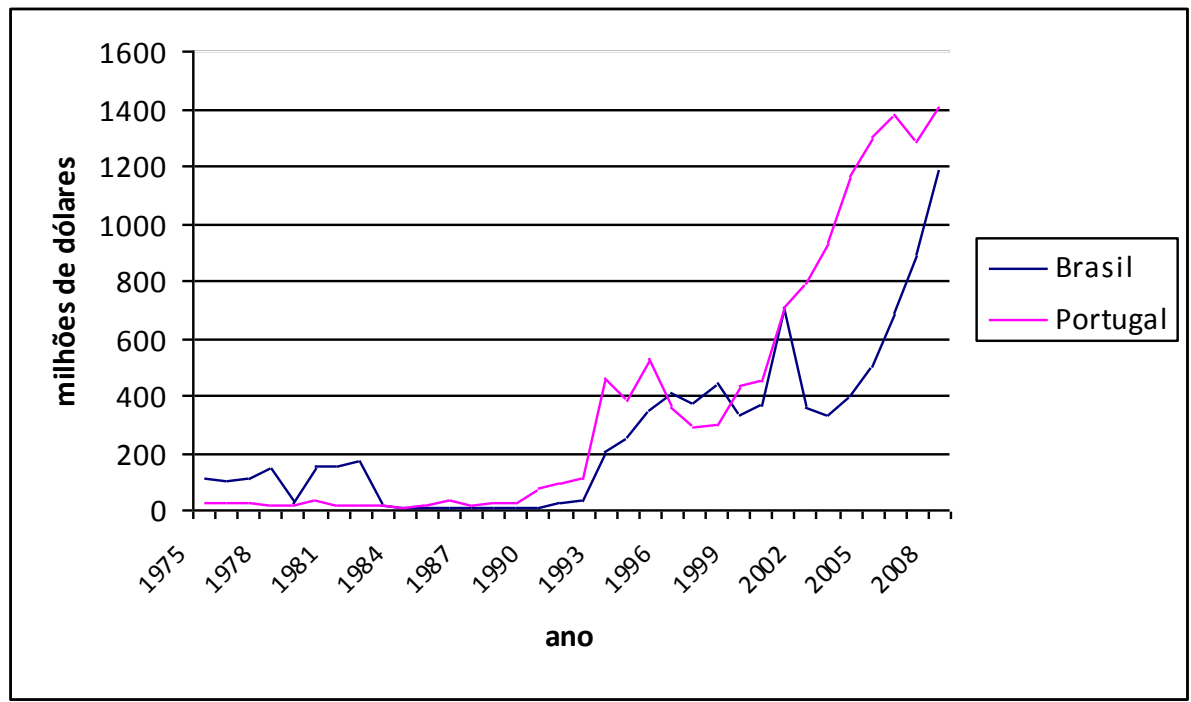

Fonte: Banco Mundial. Migration and remittances, 2010.

O gráfico 20 (Brasil e Portugal: fluxos de saída de remessas no período 1975 - 2008) revela que os fluxos de saída de remessas do Brasil não ultrapassaram os 200 milhões de dólares até 1993. De 1995 em diante, consolidam-se em valores superiores a 300 milhões. Em Portugal, por sua vez, os fluxos de saída mantiveram-se inferiores a 100 milhões até 1991. Em 1999, firmam-se acima dos 400 milhões de dólares, atingindo o pico histórico de 1,4 bilhões de dólares em 2008. Considerando a história de trânsito de pessoas entre Brasil e Portugal, conclui-se que parte considerável dos montantes enviados por um teve como destino o outro.

Tem-se, em suma, a evolução do saldo dos fluxos de remessas desses países no gráfico 21 (Brasil e Portugal: saldo dos fluxos de remessas no período 1975 - 2008). Até o início da década de 1990 os saldos anuais verificados no 
Brasil são inexpressivos; a partir de então começam a ganhar importância e, embora apresentem momentos de expansão e contração, mantém-se sempre acima de 1 bilhão de dólares. A partir de 2002, os valores atingidos ultrapassam aqueles verificados em Portugal.

Gráfico 21: Brasil e Portugal: saldo dos fluxos de remessas no período 1975 2008

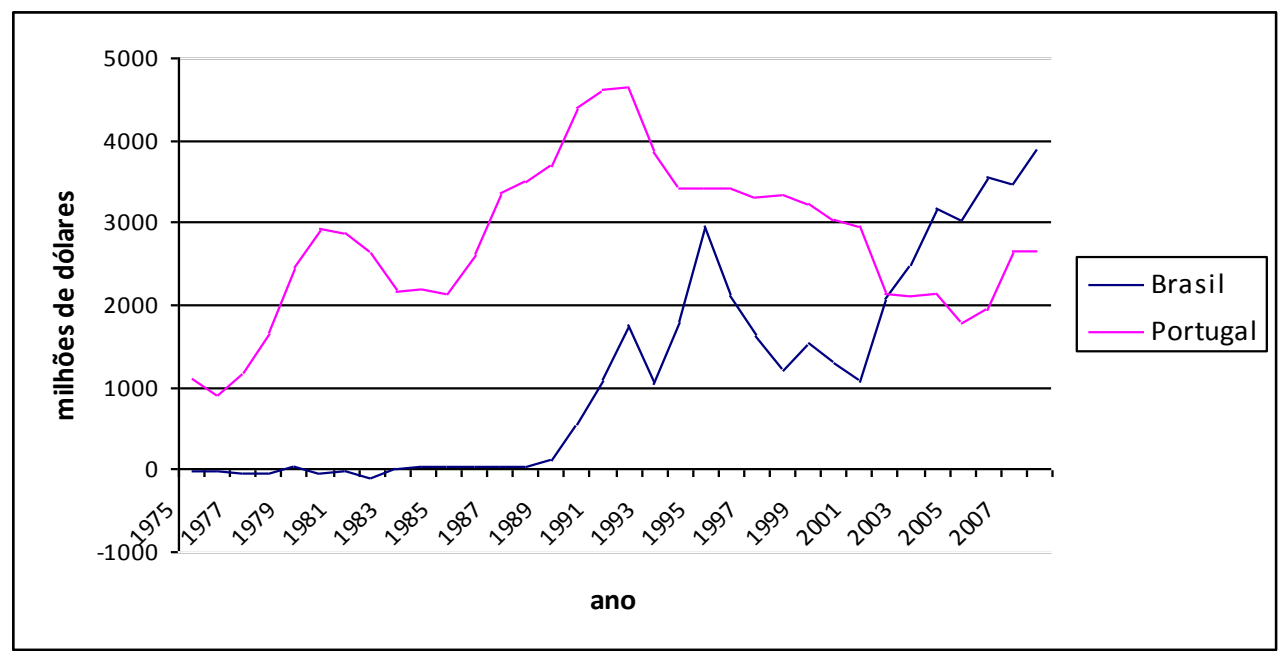

Fonte: Banco Mundial. Migration and remittances, 2010.

Exceto pelo primeiro quinquênio da década de 1980, os saldos anuais de fluxos de remessas em Portugal tenderam ao crescimento até 1992, quando após atingir um máximo de 4,6 bilhões de dólares passam a apresentar sucessivas quedas. Em 2005 atinge-se um valor mínimo próximo ao observado em 1978, isto é, aproximadamente 1,7 bilhão de dólares, mas nota-se uma inflexão: os saldos das remessas em Portugal voltam a apresentar tendências de crescimento desde então.

Portanto, no Brasil, avolumaram-se as entradas e saídas de remessas no período considerado, enquanto o saldo tende ao crescimento; já em Portugal, contraíram-se as entradas e expandiram-se as saídas, o que levou a tendência decrescente do saldo. Tais fatos refletem a relação que estes países mantiveram no que se refere a mobilidade de pessoas entre si, evidenciando a existência de alterações de padrões migratórios e, em suma, a sua inserção nos movimentos populacionais no mundo.

O fluxo de remessas de Portugal para o Brasil é crescente desde fim dos anos 1980 e o início dos anos 1990, acompanhando as variações dos fluxos 
migratórios, que conheceram períodos de contração, em meados da década de 1990, mas voltaram a aumentar na primeira década do século XXI, especialmente após 2001. Isso ocorre porque o envio de remessas ao Brasil tende a ser mais frequente nos primeiros anos de residência em Portugal. A isso se soma que a segunda onda de migrantes brasileiros é mais volumosa, possui perfil mais laboral e conta com maior participação das mulheres, as quais costumam enviar mais regularmente maior porcentagem de seus rendimentos (BID, 2010).

Notam-se, dessa maneira, atitudes diferentes quanto ao envio de remessas por parte dos migrantes na primeira e na segunda onda migratória. Dentre os que foram para Portugal na primeira leva o projeto de volta para o Brasil torna-se cada vez mais distante, as remessas tornam-se esporádicas e tem objetivos relacionados especialmente a ajuda à família. Já entre os recémchegados, o projeto de retornar ao país de origem implica esforçar-se para formar no menor tempo a maior poupança possível, com objetivos de investimentos em imóveis, bens de consumo duráveis ou abrir um pequeno negócio.

Uma imigrante brasileira de trinta e três anos de idade, que está em Portugal desde 2008, é um exemplo típico desse tipo de aspiração. Trabalhando como babá, ela contou que já comprou um terreno em Ituiutaba (MG), sua cidade natal, e que possui dinheiro na poupança que mantém no Brasil. Em suas próprias palavras: " - Tudo o que ganho aqui, invisto lá. Então, sempre fico de olho nas taxas de câmbio, quando vejo que está muito baixa eu espero subir, espero o melhor momento para mandar"82.

Rossi (2007), ao discutir o comportamento dos migrantes brasileiros em Portugal, afirma: "a fixação do imigrante implica a redução do fluxo de remessas" (p. 152). Porém, os fluxos migratórios estão permanentemente renovando-se, daí porque essas não apresentam tendência à redução.

Por assemelharem-se a doações, ou seja, por serem transferências unilaterais sem exigência de retorno, e pelo montante direcionado aos países pobres em valores absolutos, repetidamente as remessas são interpretadas como ajuda ao desenvolvimento dos países que as recebem (Rossi, 2007). Essa, aliás, é a posição defendida pelo Banco Mundial e outras instituições

\footnotetext{
${ }^{82}$ Entrevista com imigrante. Mulher. Babá. Porto. Pesquisa de campo, novembro de 2009.
} 
internacionais e acatada por diversos países de origem dos migrantes, os quais, de diferentes maneiras buscam facilitar a entrada dessas divisas.

Em Portugal, por exemplo, os emigrantes são vistos como agentes para desenvolvimento social e econômico a ponto de serem solicitados a colaborar na superação de crises. A notícia intitulada "Presidente da República apela à solidariedade dos emigrantes e à união de todos os Portugueses", publicada pela Embaixada de Portugal no Brasil, confirma essa postura:

Na mensagem do 10 de Junho, dia de Portugal, o Presidente de Portugal, Aníbal Cavaco Silva, apelou à união dos portugueses para fazer face à crise que se atravessa e, dirigindo-se em particular aos emigrantes, pediu a sua solidariedade para com o país.

O Presidente da República apelou aos emigrantes para que invistam em Portugal e para que apoiem as exportações nacionais.

"É hora de apelar à união de todos os portugueses, onde quer que se encontrem", disse Cavaco Silva (...).

"Nos tempos de crise que vivemos, (...) a acção da diáspora pode dar um importante contributo para que Portugal vença as dificuldades do presente e reencontre o caminho de crescimento económico sustentado e de melhoria das condições de vida dos cidadão", afirmou.

Cavaco Silva disse que o contributo dos emigrantes portugueses pode ser uma "mais valia" e que serão sempre "bem vindos" se decidirem apostar em Portugal, "investindo, criando riqueza, gerando emprego".

"A chave da recuperação económica reside no aumento das exportações de bens e serviços. A partilha de conhecimentos e informações entre portugueses que vivem em território nacional e aqueles que vivem e trabalham em outras partes do mundo é da maior relevância para a realização deste objectivo".

(Disponível em:

http://www.embaixadadeportugal.org.br/destaques/detalhe.php?cod_noticia=29 7, acesso em 03/11/2010)

Como país de emigração, Portugal desenvolveu estratégias e práticas para facilitar a captação das remessas enviadas pelos seus emigrantes e, igualmente, facilitar o acesso dos mesmos a financiamentos. Nesse sentido, uma experiência importante é o Sistema de Poupança-Emigrante, um sistema de depósito e crédito cujas finalidades dirigem-se para canalizar as remessas em investimentos produtivos, como sugere a citação a seguir:

"O sistema de poupança-emigrante visa financiar no território nacional:

a) A construção, a aquisição ou a benfeitoria de prédios urbanos, ou suas fracções autónomas, destinados ou não a habitação própria, bem como a aquisição ou benfeitoria de prédios rústicos destinados a exploração própria, a construção ou a rendimento; b) $A$ instalação ou o desenvolvimento de actividades industriais, agro-pecuárias ou piscatórias, inclusivamente através da realização, aquisição ou aumento de capital

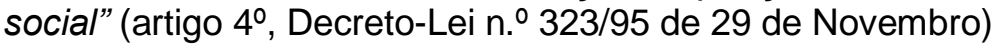


Esse sistema é uma expressão de que o Estado Português empenha-se em regular os fluxos financeiros provenientes de seus emigrantes. Essa ação estatal tem dois significados importantes: busca satisfazer as necessidades do contingente populacional que vive no exterior e, simultaneamente, procura manter essa parcela da população como recurso importante para o país.

Já no que se refere ao Brasil, o interesse do Estado com relação aos fluxos de remessas se deu bem mais recentemente, na primeira década do século XXI, mediante esforços dos próprios emigrantes e instituições internacionais e financeiras. Dois marcos importantes foram o I Encontro Ibérico de Comunidades de Brasileiros no Exterior, realizado em Lisboa em maio de 2002, em que era explícita a demanda por uma nova relação entre emigrantes e sistema bancário público do Brasil; e a I Conferência Nacional "As remessas como um instrumento de Desenvolvimento no Brasil", realizada no Rio de Janeiro em 2004, que teve como organizadores a Fundação Getúlio Vargas e o Fundo Multilateral de Investimento (FUMIN).

Como desdobramento de tais ações pode-se citar, a partir de 2004, a maior atuação internacional da Caixa Econômica Federal (CEF), banco público que é um dos principais agentes das políticas sociais do Estado brasileiro, na captação de remessas por meio de barateamento de transações bancárias e o oferecimento de serviços de investimentos via internet voltados para emigrantes que possuem cartão de crédito internacional. Em 2005, a CEF aliase ao maior banco privado português: o Millennium BCP, que atua por meio de 1.800 sucursais presentes em cerca de vinte países nos cinco continente. $O$ objetivo da parceria é possibilitar aos migrantes brasileiros que usufruam das infra-estruturas do Millennium BCP para envio de remessas portando apenas documentos de identificação de dados de quem irá receber a remessa no Brasil.

O Banco do Brasil (BB), outro banco público que funciona como instrumento de ações relacionadas a políticas sociais do Estado brasileiro, também possui importante papel nos fluxos de remessas. Isso ocorre principalmente por meio de sua infra-estrutura presente em cerca de vinte países, com destaque para aqueles em que os brasileiros são mais numerosos, 
como Japão, Estados Unidos e Portugal, neste último, o banco opera desde 1972.

A atuação destes bancos públicos revela o envolvimento do Estado brasileiro na tentativa de manter vínculos com seus emigrantes, regular as remessas e fomentar o uso desses fluxos em setores produtivos. Quanto a esse último aspecto, destacam-se o financiamento de habitações e o estímulo a empreendimentos.

Os projetos "Empreendedores Dekasseguis" e "Remessas e a Capacitação de Migrantes Brasileiros e seus Beneficiários" são exemplos de colaboração do Estado, por meio da CEF, com instituições internacionais, como o Banco Interamericano de Desenvolvimento (BID) e organizações nãogovernamentais, como o Serviço Brasileiro de Apoio à Micro e Pequena Empresa (SEBRAE). Esses projetos, porém, limitam-se aos migrantes brasileiros no Japão e nos Estados Unidos.

Não há esse tipo de iniciativa com relação aos migrantes em Portugal. A experiência portuguesa de envolvimento do Estado na busca de satisfação das necessidades dos emigrantes, entretanto, pode ser um estímulo na criação de políticas de remessas mais concretas por parte do Brasil. Essa possibilidade é ainda mais provável se for considerada a relevância que auferiram nesse país as associações de migrantes brasileiros. 


\section{Considerações Finais}

Tão antigo quanto a presença humana no planeta, o fenômeno das migrações não está esgotado. Seus conteúdos acompanham as complexas dinâmicas históricas, o que justifica revisitá-lo. Suas motivações são diversas, sendo possível mencionar a intolerância política e/ou religiosa, as crises econômicas, as catástrofes ambientais, as guerras, dentre outras.

As migrações internacionais contemporâneas são impulsionadas principalmente pelo capital, dispõem de meios de transporte rápidos e redes de informação acessíveis. Além disso, constituem objeto de preocupações crescentes de países, organismos internacionais, grupos sociais, cientistas, dentre outros.

Elas se dão em um mundo dividido em Estados nacionais. Contudo, esses se encontram em profundos processos de transformações. No contexto da globalização há modificação da lógica política, tanto no plano doméstico de um país, como no plano internacional. A idéia de independência desses planos com relação ao outro já não faz muito sentido.

Isso ocorre porque se pulverizam e fortalecem atores políticos supranacionais, organizações da sociedade civil, grandes empresas, dentre outros. Paralelamente, os Estados nacionais apresentam-se fragilizados, o que potencializa os constrangimentos à sua soberania e autonomia.

Muitas questões políticas envolvem, para sua solução, cooperação e coordenação entre Estados e demais atores políticos. Dentre estas questões, destacam-se aquelas referentes ao fenômeno das migrações internacionais. Assim, as migrações internacionais contemporâneas são dotadas de um importante conteúdo político que envolve novos atores internacionais e novas dinâmicas do espaço geográfico.

Verifica-se, portanto, a adoção de estratégias multilaterais e de consenso entre Estados de origem e Estados receptores de migrantes. Simultaneamente, é cada vez maior a articulação das decisões referentes à migração realizadas a escala das regiões supranacionais. As demandas dos migrantes também se fazem ouvir por meio de organizações que os representam, como as associações de migrantes, por exemplo. 
A concretude de tais processos, porém, só podem ser capturadas a partir de casos específicos. Tratou-se, portanto, nesta pesquisa, as migrações de brasileiros para Portugal.

A presença de brasileiros vivendo em Portugal é um novo fato no relacionamento entre os dois países. A recente situação tomou o lugar do padrão de deslocamento anterior, que tradicionalmente possuía o sentido contrário. Isso ocorreu de modo interdependente às mudanças políticas, econômicas e sociais referentes à esfera doméstica e à externa adotadas por esses dois países, principalmente após a crise do petróleo de 1973.

Portugal opta pela Europa, o Brasil opta pela América do Sul, ao passo que ambos abandonam a ditadura militar. Quando esses países pareciam afastar-se, os migrantes brasileiros "descobrem" Portugal como um país capaz de oferecer melhores perspectivas de futuro.

Constituem o perfil que caracterizaram a primeira onda migratória de brasileiros para Portugal pessoas provenientes da classe média, com grau de instrução elevado, descendentes e cônjuges de portugueses migrantes no Brasil. Posteriormente, a consolidação de redes sociais facilita o acesso de pessoas com menor renda, com grau de instrução médio e médio baixo, que não possuem ascendência portuguesa direta.

Esse conjunto diverso que compõe a comunidade brasileira tem inserção também diversa no mercado de trabalho português. Ocupam predominantemente os postos de trabalho em setores que, no período de globalização, encontram-se em expansão. São, sobretudo, trabalhadores em serviços altamente qualificados e remunerados e em serviços pouco ou nada exigentes de qualificação e que oferecem baixos salários. Mais recentemente, porém, a expansão da oferta de mão de obra de trabalhadores altamente qualificados levou à saturação em alguns setores, o que tornou mais difícil aos imigrantes em Portugal inserirem-se de modo compatível com sua formação.

Mas, independentemente da função que desempenham no mercado de trabalho e da remuneração que obtêm, todos os imigrantes tem o desafio comum de aprender a viver num país que, embora se houvesse imaginado familiar, é pouco conhecido. Na tentativa de minimizar o estranhamento, alguns se reúnem para afirmar sua identidade estrangeira. Deste modo, estabelecemse redes, criam-se associações de migrantes, algumas das quais adquirem 
grau de politização que as colocam dentre os atores que debatem as políticas migratórias tanto do país de origem como do país receptor.

Essas associações ratificam que a emigração e a imigração são faces do mesmo fenômeno, o qual obriga os países de origem e de destino a se relacionarem (Sayad, 1998). Renovam-se, portanto, antigas relações entre Brasil e Portugal, que compartilham uma população, a qual os solicita atenção.

Mas essa população compartilhada revela toda a história de trânsito de pessoas entre os dois países. É formada, assim, de portugueses no Brasil, de brasileiros em Portugal e de nacionais emigrantes retornados. Estaríamos diante, então, de uma população luso-brasileira, uma população para quem vale, ao mesmo tempo, o "estar aqui" e o "estar lá".

Justamente por sua condição híbrida, a soberania exercida sob essa população também é compartilhada entre país de origem e país receptor, que para isso lançam mão de acordos diversos. Constata-se assim que os aspectos tradicionais das relações entre território, Estado e população não desapareceram, mas adquiriram complexidade.

As afinidades históricas, culturais, os valores sociais, a língua, dentre outras, são os alicerces dessas relações. Porém, as relações entre os países no sistema internacional incluem e ultrapassam essas variáveis, abarcando elementos de estratégias geopolíticas e econômicas.

A União Européia (UE) tem como possível efeito colateral para Portugal a diminuição de sua importância relativa no sistema internacional. As relações com o Brasil e com os demais países de língua oficial portuguesa no mundo são um antídoto contra essa tendência (Lafer, 2003). Não é coincidência o fato de que a UE reconheceu a importância da Comunidade de Países de Língua Portuguesa (CPLP) em 2007, no ano em que foi presidida por Portugal.

Quanto ao Brasil, especificamente, o país concentra a maior parte da população que fala a língua portuguesa no mundo e apresenta classe média em expansão, o que o torna um mercado consumidor de peso. Além disso, sua posição de potencia emergente o fez ser destino de cerca de US\$26 bilhões em 2009, ano em que foram sentidos os efeitos da crise financeira, estando na 14ํㅜ posição dos que mais receberam IED (Unctad, 2010). Em contrapartida, o país também tem posição de destaque entre os que mais realizam 
investimentos na América do Sul e África, o que explicita suas intenções de fortalecer vínculos Sul-Sul, estratégia assumida desde 1974.

Assim, a referida soberania compartilhada é subordinada as estratégias de inserção na divisão internacional do trabalho e participação geopolítica no sistema internacional, sendo a população um componente das mesmas. Nessa perspectiva as migrações podem ser geridas de modo a fortalecer vínculos comerciais e culminar na expansão da influência de um país no mundo, colaborando para a promoção de um poder brando, tanto do país receptor como do país de origem.

Fica evidente, portanto que diante das contradições do atual período, as migrações demonstram as limitações dos Estados nacionais e reiteram sua importância, oferecendo-Ihes possibilidade de fortalecimento. Há, além disso, efetivamente, a emergência clara de uma sociedade transnacional. Junto a ela, parece se formular uma idéia de humanidade que se manifesta nos Direitos Humanos, nas questões ambientais, dentre outras. Tal consciência surge da percepção de que a humanidade é auto-destrutiva.

A construção de um federalismo transnacional, de uma multilateralização, conforme aponta Beck (1999), coloca-se como possibilidade. As ressalvas de Aron (1986), contudo, são convenientes: a consciência tribal parece, ainda, mais forte que a consciência humana.

É o que evidencia as tentativas atuais da União Européia de restringir ao máximo possível as migrações. O Brasil, assim como os demais países latinoamericanos possuem um papel fundamental no sentido de estabelecer um debate sobre as migrações de maneira a evitar sua associação a temas relacionados com a segurança, criminalidade, terrorismo.

Finalmente, o efeito politizante da globalização já se mostra evidente. Convém que se busque o caminho para sua superação mediante as possibilidades que o próprio período oferece. A globalização não é um dado, mas resulta da história e das próprias decisões humanas. Assim, enquanto criação, ela pode ser dirigida e transformada de acordo com um projeto que não se restrinja a menor parcela da população mundial. Fica para todos a proposta que é, a uma vez, utopia e desafio. 


\section{Bibliografia}

ABDALA JR (org.) Incertas Relações: Brasil e Portugal no século XX.. São Paulo: Editora Senac São Paulo, 2003.

ADITAL. "Facilitado o envio de remessas de dinheiro de brasileiros que vivem no exterior" Disponível em:

http://www.adital.com.br/Site/noticia2.asp?lang=PT\&cod=13675 (acesso em 13/11/2010).

ARON, Raymond. Paz e Guerra entra as Nações. 2ํe edição. Brasília: Editora Universidade de Brasília, 1986.

ASSIS, Gláucia de Oliveira. "Estar aqui... Estar lá". In REIS, Rossana Rocha \& Sales, Teresa (org.). Cenas do Brasil Migrante. São Paulo: Boitempo Editorial, 1999.

BACELAR, Tânia. Globalização e Território In Le Monde Diplomatique Brasil. Ano I, número 11, São Paulo, junho de 2008, pp.8-10.

BACHA, Edmar L. "Plano Real: uma segunda avaliação" In IPEA/CEPAL. O Plano Real e outras experiências internacionais de estabilização. Brasília: IPEA/CEPAL, 1997.

BAGANHA, Maria loannis (coord.) Imigração e Política. $\mathbf{O}$ caso português. Lisboa: Fundação Luso-americana, 2001.

BANCO MUNDIAL. Migration and remittances. Disponíel em: www.worldbank.org/prospects/migrationandremittances (acesso em 19/07/ 2010).

BARATA, Óscar Soares. Demografia e Sistema Internacional. Lisboa: Instituto Superior de Ciências Sociais e Políticas da Universidade Técnica de Lisboa, 2003. 
BARRICARTE, Jesús Javier Sánchez. Socioeconomía de las migraciones em un mundo globalizado. Madri: Editoria Biblioteca Nueva, 2010.

BASSANEZI, Maria Silvia C. Beozzo. "Imigrações Internacionais no Brasil: Um panorama Histórico" In PATARRA, Neide Lopes (coord.). Emigração e Imigração Internacionais no Brasil Contemporâneo. São Paulo: $2^{\underline{a}}$ ed., FNUAP, 1995, pp. 1-38.

BRASIL. Decreto n7.214 de 15 de junho de 2010. Estabelece princípios e diretrizes da política governamental para as comunidades brasileiras no exterior. Disponível em: http://www.brasileirosnomundo.mre.gov.br/ptbr/News.xml (acesso em 10/07/2010).

BEAUJEU-GARNIER, J. Geografia da População. São Paulo: Companhia Editora Nacional, 1967.

BECK, Ulrich O que é globalização? Equívocos do globalismo: respostas à globalização. São Paulo: Paz e Terra, 1999.

BECKER, Bertha \& EGLER, Cláudio A. G. Brasil: nova potência regional na economia-mundo. Rio de Janeiro: Bertrand Brasil, 2003.

BECERRIL, Juan Gabino González (coord.). Migración Internacional. Efectos de la globalización y las políticas migratórias. Toluca: Centro de Investigación y Estudios Avanzados de la Población, UNAM, 2007.

BHAGWATI, Jagdish N. Em defesa da globalização: como a globalização está ajudando ricos e pobres. Rio de Janeiro: Elsevier, 2004. pp.31-38, 223295.

BIELSCHOWSKY, Ricardo. Pensamento Econômico Brasileiro: o ciclo ideológico do desenvolvimentismo $-3^{\circ}$ ed. Rio de Janeiro: Contraponto, 1996. 
BÓGUS, Lúcia Maria Machado. "Esperança Além-Mar: Portugal no "arquipélago migratório" brasileiro". In MALHEIROS, Jorge Macaísta (org.) Imigração Brasileira em Portugal. Lisboa: ACIDI, 2007, pp.: 39-58.

BRASIL ECONÔMICO. "A nova classe média" Disponível em: http://www.brasileconomico.com.br/noticias/a-nova-classe-media_82800.html. (acesso em 20/06/2010).

CASTELLS, Manuel, "Para o Estado-rede: globalização econômica e instituições políticas na era da informação" In PEREIRA, Luiz Carlos Bresse (et. alli.) (orgs). Sociedade e Estado em Transformação. São Paulo: Editora Unesp, Enap e Imprensa Oficial, pp.147-171.

CBL. "A 2 vaga da imigração brasileira para Portugal (1998-2003): Estudo de opinião a imigrantes residentes nos distritos de Lisboa e Setúbal Informações estatísticas e elementos de análise" In MALHEIROS, Jorge Macaísta (org.) Imigração Brasileira em Portugal. Lisboa: ACIDI, 2007.

CEPAL. La inversión extranjera en América Latina. Informe,1997. Santiago: Naciones Unidas, 1998.

CEPAL. La inversión extranjera directa en América Latina. Santiago: Naciones Unidas, 2009.

CHELIUS, Letícia Calderón. "Redefinindo a geografia política nacional: sobre a participação política dos cidadãos brasileiros no exterior" In MALHEIROS, Jorge Macaísta (org.). Imigração Brasileira em Portugal. ACIDI, Lisboa: Observatório da Imigração, 2007.

CUNHA, Isabel Ferin. "A mulher brasileira na televisão portuguesa" In Actas do III SOPCOM, VI LUSOCOM e II IBÉRICO - Volume III. Covilhã, 2005. 
DIÁRIO DE NOTÍCIAS. Mais de $11 \%$ dos médicos inscritos são estrangeiros. 01, setembro, 2009. Texto disponível em http://dn.sapo.pt/inicio/portugal/interior.aspx?content_id=1349526, acesso em 25 de junho de 2010.

DIAS, Leila Christina. "Os sentidos da Rede: Notas para Discussão" In DIAS, Leila Christina \& SILVEIRA, Rogério L.L. (orgs.) Redes, sociedade e territórios. Santa Cruz do Sul: EDUNISC, 2005, pp. 10-28.

DIAS, Cláudia Sérvulo da Cunha (coord.). Tráfico de pessoas para fins de exploração sexual. Brasília: OIT, 2005.

DIAS, Sonia Ferreira \& ROCHA, Cristianne Famer. Saúde Sexual e reprodutiva de mulheres imigrantes africanas e brasileiras: um estudo qualitativo. Estudos OI 32. Lisboa: ACIDI, 2009.

DIEESE. A conjuntura econômica recente. Crise financeira e vulnerabilidade do real. DIEESE, 1998. Texto disponível em http://dieese.org.br/esp/real/crisereal.xml, acesso em 26 de maio de 2010.

DEMARTINI, Zeila de Brito Fabri \& TRUZZI, Oswaldo (orgs.). Estudos Migratórios. Perspectivas metodológicas. São Carlos: Edufscar, 2005.

DEUTSCHE WELLE. Agências publicitárias brasileiras conquistam mercado em Portugal. Texto disponível em http://www.dwworld.de/dw/article/0,,5441768,00.html, acesso em 29 de junho de 2010.

DOMENECH, Eduardo. "La ciudadanización de la política migartoria em la región sudamericana: vicisitudes de la agenda global" In NOVICK, Susana (compiladora). Las migraciones em América Latina. 1ed. Buenos Aires: Catálogos, 2008.

DURAND, Marie Françoise (et alli). Atlas da Mundialização, dossiê especial Brasil. São Paulo: Editora Saraiva, 2009. Disponível em www.sciencespo.fr/cartographie (acesso em 06/05/2009)

INSTITUTO DE ESTUDOS AVANÇADOS. Revista de Estudos Avançados, 57. Dossiê Migrações. Vol. 20, maio/agosto 2006. São Paulo. 
EXPRESSO PT. Fábrica da Embraer em Évora começa a laborar em 2012. Expresso PT, 26/06/2009. Texto disponível em aeiou.expresso.pt/aeronauticafabrica-da-embraer-em-evora-comeca-a-laborar-em-2012=f527886, acesso em 23 de junho de 2010.

FAPESP. Talentos em Transito. Revista Pesquisa Fapesp n 152. São Paulo, outubro de 2008, pp. $30-35$.

FERREIRA, Ricardo Hirata. Migrações Internacionais: Brasil ou Japão. 0 movimento de inserção do dekassegui no espaço geográfico pelo consumo. Tese de doutorado apresentado ao DG/ FFLCH/USP, 2007.

FOLHA DE SÃO PAULO. "Historiador Eric Hobsbawm aponta questões cruciais do século 21". Caderno llustrada. 18/04/2010.

FONSECA, Maria Lucinda. "Inserção Territorial - Urbanismo, Desenvolvimento Regional e Políticas Locais de Atracção". In VITORINO, António (coord) (et alli). Imigração: Oportunidade ou ameaça? Recomendações do Fórum Gulbenkian Imigração. São João do Estoril, Portugal: Principia, 2007, pp. 105-150.

FONSECA, Maria Lucinda (et. alli.). Reunificação Familiar e Imigração em Portugal. ACIDI, Lisboa: Observatório da Imigração, 2005.

FOUREZ, Gérard. "Reflexões Epistemológicas. O método científico: a Observação" In FOUREZ, Gerard. A construção das Ciências. Introdução à Filosofia, e à Ética das Ciências. São Paulo, UNESP, 1995, pp; 37-44.

GÓIS, Pedro \& MARQUES, José Carlos. Estudo prospectivo sobre imigrantes qualificados em Portugal. Estudos OI; 24. Lisboa: ACIDI, 2007.

GONÇALVES, Pe. Alfredo J. "O fenômeno migratório no mundo na conjuntura atual" In Seminário sobre Direitos Humanos e Migrações, 15 de junho de 2004, Canoas/RS. 
GOTTMANN, Jean. La Politique des États et leur Géographie. Paris: Librairie Armand Colin, 1952.

GOTTMAN, Jean. The political partitioning of our world: an attempt at analysis. Word Politics, v. 4, n. 4, 1952, p. 512-519.

GOUROU, Pierre. Introdución a la geografia humana. Madri: Alianza Editorial, 1984.

GUEDES, Gilvan Ramalho \& MARQUES, Denise Helena Franca. Migração e mercado de trabalho em Portugal: uma análise comparativa entre brasileiros e africanos lusófonos In Anais do XVI Encontro Nacional de Estudos Populacionais, ABEP. Caxambu, 2008.

GUERRA, Alexandre (et alli) (orgs.). Atlas da Nova Estratificação Social no Brasil, vol. 1. Classe Média. Desenvolvimento e Crise. São Paulo: Cortez Editora, 2006.

HAESBAERT, Rogério. O mito da Desterritorrialização: do "fim dos territórios à multiterritorialidade. Rio de Janeiro: Bertrand Brasil, 2004.

HALL, Joan. "Diez años de innovacción em remessas: lecciones aprendidas y modelos para el futuro". Washington D.C. FUMIN - BID, 2010. Disponível em:

http://idbdocs.iadb.org/wsdocs/getdocument.aspx?docnum=35163517 (acesso em 11/09/2010).

HEIDEMANN, Heinz Dieter \& SILVA, Sidney Antonio da (orgs.) Coletânea de textos do Simpósio Internacional Migração: nação, lugar e dinâmicas territoriais. São Paulo: Editora Humanitas, 2007.

HELLER, Agnes. Uma revisión de la teoria de las necesidades. Barcelona: Ediciones Paidós Ibérica, 1996. 
HARVEY, David. A condição pós moderna. São Paulo: Loyola, 1992

HOBSBAWM, Eric. A era do capital (1848 - 1875). Rio de Janeiro: Paz e Terra, 2002.

HORTA, Ana Paula Beja (coord.) Associativismo imigrante. Migrações. Revista do Observatório da Imigração, nº, abril de 2010.

HUNTINGTON, Samuel P. “Choque das Civilizações?” In Política Externa. Vol2, n4, março, 1994.

IANNI, Octávio. Estado e planejamento econômico no Brasil (1930 - 1970). Rio de Janeiro, 1977.

IBGE. Contagem da População - 2007. Instituto Brasileiro de Geografia e Estatística. São Paulo, 2007.

INE. Dia Internacional da Mulher. Destaque. Informação à Comunicação Social. Instituto Nacional de Estatística, 05 de março de 2010.

- Estatísticas de Emprego 2009. Instituto Nacional de Estatística. Lisboa, $4^{\circ}$ trimestre de 2009.

. Portugal Social 1991-2001. Instituto Nacional de Estatística. Lisboa, 2003.

IPEA. Brasil: O Estado de uma Nação. Mercado de Trabalho, Emprego e Informalidade. Instituto de Pesquisa Econômica Aplicada. Brasília, 2006. 
PNAD 2006. Primeiras Análises. demografia, educação, trabalho, desigualdade de renda e pobreza. Instituto de Pesquisa Econômica Aplicada. Brasília/Rio de Janeiro, 2007.

. Comunicado da Presidência, no34. Trajetória recente da mudança na identidade e na estrutura social brasileira. Instituto de Pesquisa Econômica Aplicada. Brasília, 2006.Novembro de 2009.

JACINTO, José Luís Moura. "As migrações e as relações internacionais" In Imigração e Mercado de Trabalho. Cadernos Sociedade e Trabalho, №2, 2002, pp97-130.

JAPIASSU, Hilton Ferreira, 1934 - Introdução ao pensamento epistemológico. Rio de Janeiro: F. Alves, 2ª ed., 1977.

KLAGSBRUNN, Victor Hugo "A migração internacional de brasileiros para os países desenvolvidos após o 11/9/2001. Condicionantes e perspectivas diante de mudanças nas relações internacionais e nos mercados de trabalho brasileiro e dos países desenvolvidos" In I Conferência das Comunidades Brasileiras no Exterior. Ministério das Relações Exteriores e Fundação Alexandre Gusmão, Julho de 2008.

KNOPFLI, Francisco (coord). As políticas exteriores de Brasil e Portugal: visões comparadas. Lisboa: Instituto Superior de Ciências Sociais e Políticas, Universidade Técnica de Lisboa, 2004.

LAGES, Mário F. (et alli). Os imigrantes e a população portuguesa. Imagens recíprocas: Análise de duas sondagens. Lisboa: Observatório da Imigração/ACIME, 2006.

LAFER, Celso. "Relações Brasil-Portugal: passado, presente, futuro" In ABDALA JR (org.) Incertas Relações: Brasil e Portugal no século XX.. São Paulo: Editora Senac São Paulo, 2003. 
MACHADO, Igor. "Imigração em Portugal" In INSTITUTO DE ESTUDOS AVANÇADOS. Revista de Estudos Avançados, 57. Dossiê Migrações. Vol. 20, maio/agosto 2006. São Paulo.

MACHADO, Igor. Reflexões sobre as identidades brasileiras em Portugal. In MALHEIROS, Jorge Macaísta (org.). Imigração Brasileira em Portugal. ACIDI, Lisboa: Observatório da Imigração, 2007. pp. 217-226.

MAGALHÃES, JOSÉ Calvet de. Breve História das Relações Diplomáticas entre Brasil e Portugal. São Paulo: Paz e Terra, 1999.

MALHEIROS, Jorge Macaísta (org.). Imigração Brasileira em Portugal. ACIDI, Lisboa: Observatório da Imigração, 2007.

MARTINS, Carlos Eduardo da Rosa. Globalização, dependência e neoliberalismo na América Latina. Tese de doutorado. Departamento de Sociologia. FFLCH/USP. São Paulo, 2003.

MEDEIROS, Carlos Alberto. Esboço breve de Geografia Humana. Lisboa: Terra Livre, 1976.

MEGALE, Januário Francisco. Max Sorre. Coleção Grande Cientistas Sociais, no 46. São Paulo: Editora Ática, 1984.

MRE. Brasileiros no Mundo: Estimativas. 2a edição, Setembro de 2009. Disponível em www.brasileirosnomundo.mre.gov.br (acesso realizado em 28/04/2010).

MINISTÉRIO DO TRABALHO E EMPREGO (et alli). Brasileiras e Brasileiros no Exterior. Informações Úteis. Brasília: TEM, Coordenação Geral de Imigração, 2007.

MIRANDA, Joana. Mulheres Imigrantes em Portugal: Memórias, Dificuldades de Integração e Projectos de Vida. Estudos OI 35. Lisboa: ACIDI, 2009. 
MORAES, Antônio Carlos Robert (org.). Ratzel. Coleção Grande Cientistas Sociais, no 59. São Paulo: Editora Ática, 1990

MORAES, Orozimbo. Investimento direto estrangeiro no Brasil. São Paulo: Aduaneiras, 2002.

MOURÃO, Fernando A. A. "Alca - Mercosul: um discurso desfocado" In CASELLA, Paulo Borba e SANCHEZ, Rodrigo Elian (coords.). Quem tem medo da ALCA? Belo Horizonte: Del Rey, 2005, pp. 349-396.

NIESSEN, Jan (et alli). Migrant Integration Policy Index. Bruxelas: British Council \& Migration Policy Group, 2007.

NOTÍCIAS AGRÍCOLAS. "Com cotação maior, café deverá render mais neste ano" Disponível em: www.noticiasagricolas.com.br (acesso em 12/01/2010).

NOVICK, Susana (compiladora). Las migraciones em América Latina. $1^{\circ} \mathrm{ed}$. Buenos Aires: Catálogos, 2008.

O ESTADO DE SÃO PAULO. Publicidade lusa, sotaque brasileiro. 16 de novembro de 2009.2 Texto disponível em http://www.estadao.com.br/estadaodehoje/20091116/not_imp466947,0.php, acesso em 29 de junho de 2010.

ORDEM DOS ENFERMEIROS. Dados Estatísticos 2000-2009. Janeiro, 2010. Disponível em:

http://www.ordemenfermeiros.pt/membros/Documents/OE_Dados_Estatisticos_ 2000_2009_VFinal.pdf (acesso em 25/06/2010).

ORDEM DOS MÉDICOS DENTISTAS. Os números da ordem. Estatísticas, 2010. Texto disponível em www.omd.pt, acesso em 24 de junho de 2010.

PADILHA, Beatriz. "Acordos Bilaterais e legalização: o impacte na integração dos imigrantes brasileiros em Portugal” In MALHEIROS, Jorge 
Macaísta (org.). Imigração Brasileira em Portugal. ACIDI, Lisboa: Observatório da Imigração, 2007. pp. 217-226.

OIT BRASIL. Tráfico de pessoas para fins de exploração sexual. Brasília: OIT, 2006.

PADILHA, Beatriz. "A imigrante brasileira em Portugal” In MALHEIROS, Jorge Macaísta (org.). Imigração Brasileira em Portugal. ACIDI, Lisboa: Observatório da Imigração, 2007, pp. 113-134.

PAIVA, Odair da Cruz. Caminhos Cruzados. Migração e construção do Brasil Moderno (1930 - 1950). Bauru, SP: Edusc, 2004.

PATARRA, Neide Lopes (coord). Emigração e Imigração Internacionais no Brasil Contemporâneo. São Paulo: FNUAP, 1995.

PEDRO, Rui da Silva. "A Obra Católica Portuguesa de Migrações e o movimento imigrante em Portugal. Percursos e desafios" In HORTA, Ana Paula Beja (coord.) Associativismo imigrante. Migrações. Revista do Observatório da Imigração, №6, abril de 2010.

PEIXOTO. João. (coord.) Análise do Mercado de Remessas Portugal/Brasil. Lisboa: Banco Interamericano de Desenvolvimento, maio 2006.

PEIXOTO. João. "Emprego e Proteção Social. Oportunidades no mercado de trabalho português, competição e complementaridade, reconhecimento de habilitações e de competências, projectos da Gulbenkian, empreendedorismo". In VITORINO, António (coord.) (et alli). Imigração: Oportunidade ou ameaça? Recomendações do Fórum Gulbenkian Imigração. São João do Estoril, Portugal: Principia, 2007, pp. 199-231.

PEIXOTO. João \& FIGUEIREDO, Alexandra. "Imigrantes brasileiros e mercado de trabalho em Portugal" In MALHEIROS, Jorge Macaísta (org.). Imigração Brasileira em Portugal. ACIDI, Lisboa: Observatório da Imigação, 2007

PINHO, Filipa. "A imprensa na construção do processo migratório: a constituição de Portugal como destino plausível da emigração brasileira" 
In MALHEIROS, Jorge Macaísta (org.). Imigração Brasileira em Portugal. ACIDI, Lisboa: Observatório da Imigação, 2007.

PORTUGAL. Constituição, 1976. Constituição da República Portuguesa. Lisboa, 1976.

Decreto Lei 212/92 de 12 de outubro. Dispõe sobre regularização excepcional de imigrantes. Ministério da Administração Interna. Disponível em:

http://www.igf.min-

financas.pt/inflegal/bd_igf/bd_legis_geral/Leg_geral_docs/DL_212_92.htm (acesso em 03/09/2010).

.Decreto Lei 244/ 1998 de 8 de agosto. Regula a entrada e permanência e saída de estrangeiros em Portugal. Disponível em: http://www.sef.pt/portal/v10/PT/aspx/legislacao/index.aspx?id_linha=4191\&men u_position=4133 (acesso em 05/09/2010)

.Decreto Lei 97/1999 de 26 de julho. Altera o Decreto Lei 244/ 1998 de 8 de agosto. Disponível em:

http://www.sef.pt/portal/v10/PT/aspx/legislacao/index.aspx?id_linha=4191\&men u_position=4133 (acesso em 05/09/2010)

.Decreto Lei 4/2001 de 10 de janeiro. Dispõe sobre entrada e permanência e saída de estrangeiros em Portugal. Disponível em: http://www.sef.pt/portal/v10/PT/aspx/legislacao/index.aspx?id_linha=4191\&men u_position=4133 (acesso em 05/09/2010)

Decreto Lei 34/2003 de 25 de fevereiro. Altera o regime jurídico da entrada, permanência, saída e afastamento de estrangeiros do território nacional. Disponível em:

http://www.sef.pt/portal/v10/PT/aspx/legislacao/index.aspx?id_linha=4191\&men u_position=4133 (acesso em 05/09/2010) 
. Lei 23/2007 de 4 de julho. Aprova o regime jurídico de entrada, permanência, saída e afastamento de estrangeiros do território nacional.

Disponível em:

http://www.sef.pt/portal/v10/PT/aspx/legislacao/index.aspx?id_linha=4191\&men u_position=4133 (acesso em 05/09/2010)

Decreto-Lei n.. $323 / 95$ de 29 de Novembro. Dispõe sobre o sistema poupança-emigrante. Disponível em:

http://www.portaldocidadao.pt/PORTAL/pt/Servicos (acesso em 19/09/2010).

PÓVOA NETO, Hélion. "A imagem da imprensa sobre a emigração brasileira" In Dossiê Migrações. Revista Estudos Avançados, no 57. Vol. 20, maio-agosto de 2006. Instituto de Estudos Avançados da Universidade de São Paulo, pp. 25-40.

"Migrações internas e mobilidade do trabalho no

Brasil atual. Novos desafios para a análise" In HEIDEMANN, Heinz Dieter \& SILVA, Sidney Antonio da (orgs.) Coletânea de textos do Simpósio Internacional Migração: nação, lugar e dinâmicas territoriais. São Paulo: Editora Humanitas, 2007. pp. 45-56.

PRADO JÚNIOR, Caio. Evolução Política do Brasil e outros estudos. 10ª ed. São Paulo: Brasiliense, 1977.

PRADO JÚNIOR, Caio. Formação do Brasil Contemporâneo: colônia. 23a ed. São Paulo: Brasiliense, 2004 (1ª edição 1942).

PNUD. Relatório de Desenvolvimento Humano 2009. Ultrapassar Barreiras: Mobilidade e Desenvolvimento Humanos. Coimbra: Edições Almedina, 2009.

RAFFESTIN, Claude. Por uma Geografia do Poder. São Paulo: Ed. Ática, 1993. 
REIS, Rossana. Construindo Fronteiras. Políticas de Imigração na França e nos Estados Unidos (1980-1998). Tese de doutorado. Departamento de Ciência Política. FFLCH/USP, 2003.

REIS, Rossana Rocha \& Sales, Teresa (org.). Cenas do Brasil Migrante. São Paulo: Boitempo Editorial, 1999.

ROCHA-TRINDADE, Maria Beatriz. A presença dos ausentes. In Sociedade e território. Revista de estudos urbanos e regionais. Dossier Espaço - Emigração e Retorno. Ano 3/ número 8/ fevereiro 1989. Porto: Edições Afrontamento, pp. 8-16.

A realidade da imigração em Portugal. Actas do I Congresso sobre imigração em Portugal: Diversidade - Cidadania Integração. Lisboa, julho de 2004.

. "Associativismo em contexto migratório" In HORTA, Ana Paula Beja (coord.) Associativismo imigrante. Migrações. Revista do Observatório da Imigração, nํㅡ, abril de 2010.

Emigração. In Dicionário llustrado da História de Portugal. Volume 1. Lisboa: Alfa, 1986, pp.205-207.

História da imigração em Portugal (I) e (II). In Janus 2001. Anuário de Relações Exteriores. Lisboa Público \& Universidade de Lisboa, 2001, pp.69-70.

História das migrações portuguesas. In Janus 2001. Anuário de Relações Exteriores. Lisboa: Público \& Universidade de Lisboa, 2002, pp.170 - 173.

Migrações dos Países Lusófonos. In CRISTÓVÃO, Fernando (Dir. e Coord.). Dicionário Temático da Lusofonia. Lisboa: Texto editores, 2005, pp. $705-707$. 
- Sociologia das Migrações. Lisboa: Universidade

Aberta, 1995.

. \& CAEIRO, Domingos. Portugal - Brasil. Migrações

e migrantes. 1850 - 1930. Lisboa: Edições INAPA, 2000.

RODRIGUES, Teresa Ferreira. História da População Portuguesa. Porto: Edições Afrontamento, 2009.

ROSENAU, James N. \& CZEMPIEL, Ernst-Otto (orgs.) Governança sem Governo: ordem e transformação na política mundial. Brasília: Editora da Unb; Imprensa Oficial, 2000.

ROSSI, Pedro. "Remessas de imigrantes: estudo de caso de brasileiros em Portugal" In MALHEIROS, Jorge Macaísta (org.). Imigração Brasileira em Portugal. ACIDI, Lisboa: Observatório da Imigração, 2007.

ROSSINI, Rosa Ester. A presença do ausente: migrantes nikkeis do Brasil no Japão, migrantes japoneses no Brasil. In REIS, Raquel (org.). Actas do Congresso Solidariedade Intergeracional. Lisboa. FCT/CEMRI/Universidade Aberta, 2008.

Da intenção de voltar a "necessidade" de ficar: a presença do Brasil no Japão (1985-2005). In Anais do XV Encontro Nacional de Estudos da População - ABEP, Caxambu, 2006.

. "Migração dos dekasseguis do Brasil na terra do sol nascente: tendências atuais" In BECERRIL, Juan Gabino González (coord.). Migración Internacional. Efectos de la globalización y las políticas migratórias. Toluca: Centro de Investigación y Estudios Avanzados de la Población, UNAM, 2007. 
SALES, Teresa. "Novos Fluxos Migratórios da População Brasileira" In Revista Brasileira de Estudos Populacionais, 8 (1/2), Campinas, 1991.

SANTOS, Boaventura de Sousa. (et alli). Tráfico de Mulheres em Portugal para fins de exploração sexual. Coimbra: CES \& CAIM, 2007.

SANTOS [a], Milton. A natureza do espaço. Técnica e tempo, razão e emoção. São Paulo: Editora da Universidade de São Paulo, 2002.

.Para que a geografia mude sem ficar a mesma coisa" In Revista RA'E GA, Curitiba, n.9, p 125-134, 2005. Editora UFPR.

O espaço dividido: os dois circuitos da economia urbana dos países subdesenvolvidos. $2^{\mathrm{a}} \mathrm{ed}$. São Paulo: Editora da Universidade de São Paulo, 2004

Por uma outra globalização: do pensamento único à consciência universal. São Paulo: Record, 2001.

. "Região: Globalização e Identidade" In LIMA, Luiz Cruz (org.). Conhecimento e Reconhecimento. Fortaleza: EDUECE, 2003, pp. 53-64.

. "Sociedade e Espaço: A Formação Social como Teoria e como Método" In SANTOS, Milton. Espaço e Sociedade (Ensaios). 2º Edição. Petrópolis: Editora Vozes, 1982, pp.9-27.

SANTOS [b], Vanda. O discurso oficial do Estado sobre a emigração dos anos 60 a 80 e imigração dos anos 90 à actualidade. Observatório da Imigração, 8. Lisboa: Alto Comissariado para Imigração e Minorias Étnicas (ACIME). Outubro, 2004.

SASSEN, Saskia. Los espectros de La globalización. Buenos Aires: Fondo de Cultura Económica, 2003. 
SAYAD, Abdelmalek. A Imigração ou os Paradoxos da Alteridade. São Paulo: Editora da Universidade de São Paulo, 1998.

SCHILLER, Dan. A globalização e as novas tecnologias. Lisboa: Editorial Presença, 2002, pp. 58-111.

SEABRA, Odette (et. alli). Território e Sociedade. Entrevista com Milton Santos. $2^{\mathrm{a}}$ ed. São Paulo: Editora Fundação Perseu Abramo, 2000.

SEF. Relatório Estatístico 2000. Lisboa: Núcleo de Planeamento do Serviço de Estrangeiros e Fronteiras, 2001.

SEF. Relatório Estatístico 2007. Lisboa: Núcleo de Planeamento do Serviço de Estrangeiros e Fronteiras, 2008.

SEF. Relatório Estatístico 2009. Lisboa: Núcleo de Planeamento do Serviço de Estrangeiros e Fronteiras, 2010.

SENE, Eustáquio de. Globalização e Espaço Geográfico. 2ª edição. São Paulo: Contexto, 2004.

SILVA, Adriano Larentes da. "Imigrantes brasileiros em Portugal: da década de 1980 aos dias atuais" In Atas do Seminário do Núcleo de Estudos de Migrações, dez. 2007.

SILVA, Joaquim Ramos. Portugal/Brasil. Uma década de expansão das relações econômicas, 1992-2002. 1ª edição. Lisboa: Terramar, 2002.

SILVA, Maria Aparecida de Moraes. "Contribuições Metodológicas para a análise das migrações". In DEMARTINI, Zeila de Brito Fabri \& TRUZZI, Oswaldo (orgs.) Estudos Migratórios. Perspectivas metodológicas. São Carlos: Edufscar, 2005, pp. 53-86. 
SILVA, Luis Inácio Lula da. Carta aos Brasileiros que vivem longe de casa. Partido dos Trabalhadores, 2002.

SILVA, Sandra \& SCHILTZ, Aline. “A relação entre os imigrantes brasileiros e os Portugueses - a construção de imagens recíprocas" In MALHEIROS, Jorge Macaísta (org.). Imigração Brasileira em Portugal. ACIDI, Lisboa: Observatório da Imigração, 2007. pp. 217-226.

SINGER, Paul Israel. Desenvolvimento econômico e evolução urbana: análise da evolução econômica de São Paulo, Blumenau, Porto Alegre, Belo Horizonte e Recife. São Paulo: Editora Nacional, 1974.

SILVEIRA, Maria Laura. "Por uma epistemologia geográfica" In BERTONCELLO (et alli) (orgs.) Procesos Territoliales en Argentina y Brasil. Buenos Aires: Editora de la Universidad de Buenos Aires, 2003, pp. 15-26.

SORRE. Max. Les migrations des peuples : essai sur la mobilité géographique. Paris: Flammarion, 1955.

SPRANDEL, Márcia Anita. Brasileiros na Fronteira com o Paraguai In. Revista Estudos Avançados, no 57. Vol. 20, maio-agosto de 2006. Instituto de Estudos Avançados da Universidade de São Paulo.

STIGLITZ, Joseph E. A globalização e seus malefícios. São Paulo: Futura, 2002, pp.209- 239 .

SZESZ, Christiane Marques (et alli) (orgs.). Portugal - Brasil no século XX: sociedade, cultura e ideologia. Bauru: EDUSC, 2003.

TIME EUROPE. "When the meninas came to town". Outubro, 20,2003, Vol 162. №15.

TREWARTHA. Glenn. Geografia da População. Padrão Mundial. São Paulo: Editora Atlas S. A., 1974. 
UNITED NATIONS. Indicator on Population. In United Nations Statistics Division. Demographic and Social Statistics. Statistical Products and Databases. Social Indicators, 2009.

Trends in International Migrant Stock: The 2008

Revision. Department of Economic and Social Affairs, Population Division (2009). (United Nations database, POP/DB/MIG/Stock/Rev.2008).

UNFPA. State of world population 2006. A passage to hope. Women and international migration. UNFPA, 2006.

UNODC. Trata de personas hacia Europa con fines de explotación sexual. Viena, Áustria: United Nations Office on Drugs and Crime, 2010,

ÚNICA, 2009. Estatísticas: Dados e cotações. Disponível em: http://www.unica.com.br/dadosCotacao/estatistica/ (acesso em 10/07/2010).

VAINER, Carlos B. "Reflexões sobre o poder de mobilizar e imobilizar na contemporaneidade" In PÓVOA NETO, Hélion \& FERREIRA, Ademir P. (orgs). Cruzando Fronteiras disciplinares: um panorama dos estudos migratórios. Rio de Janeiro: Revan, 2005.

VERRIÉRE, Jacques. As políticas de População. $2^{\mathrm{a}}$ edição. Rio de Janeiro. Bertrand Brasil, 1991.

VIANA, Carlos. Audiograma. Sociologia das Migrações. Entrevista concedida à Profa. Maria Beatriz da Rocha-Trindade no âmbito do curso de Sociologia das Migrações. Universidade Aberta, 1995.

VIANA, Carlos. "O desafio das associações de imigrantes" In HORTA, Ana Paula Beja (coord.) Associativismo imigrante. Migrações. Revista do Observatório da Imigração, ํo6, abril de 2010. 
VISÃO PT. "Compare o salário mínimo português com os da UE e dos EUA". Disponível em http://aeiou.visao.pt/compare-o-salario-minimoportugues-com-os-da-ue-e-dos-eua=f543243 (acesso em 29/09/2010).

VITORINO, António (coord) (et alli). Imigração: Oportunidade ou ameaça? Recomendações do Fórum Gulbenkian Imigração. São João do Estoril, Portugal: Principia, 2007.

ZELINSKY, Wilbur. Introdução à Geografia da População. Rio de Janeiro: Zahar editores, 1969.

\section{Sites Visitados}

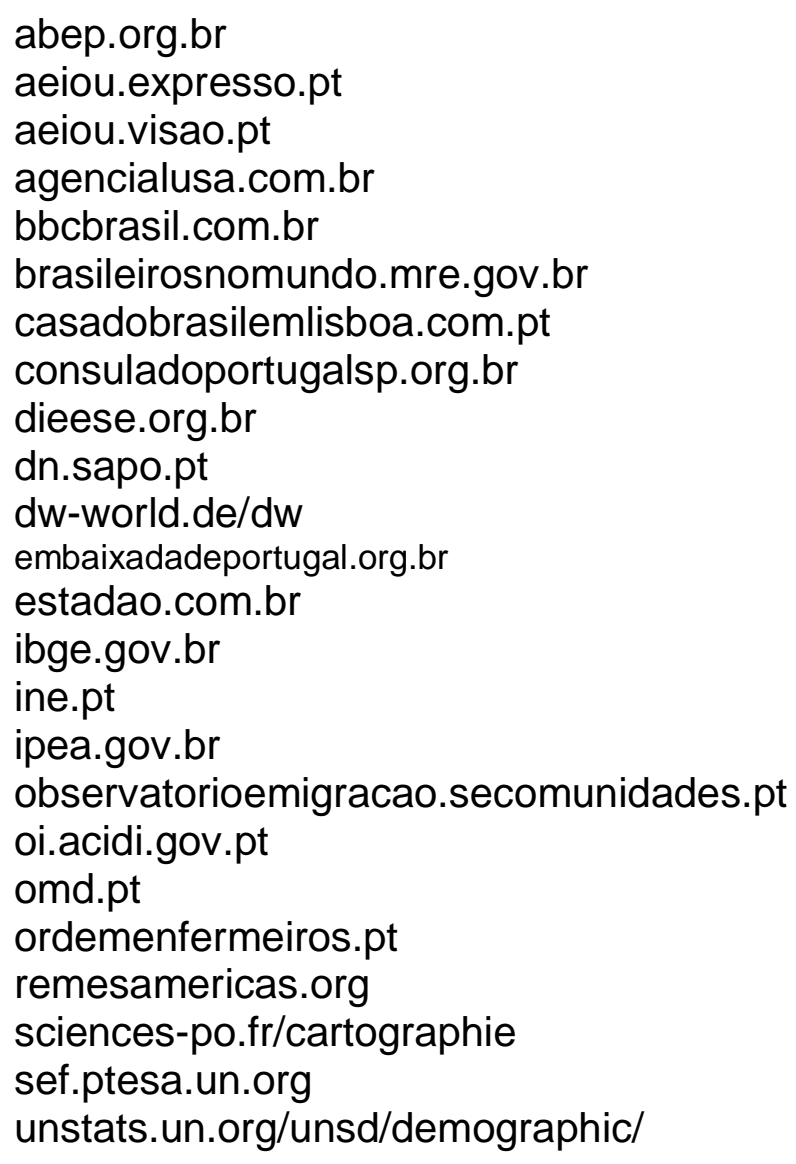

